\title{
Chapter 4 \\ In the Realm of Opportunity: The Kaiser \\ Wilhelm Institute for Anthropology, Human \\ Heredity and Eugenics during World War II, \\ 1938/42-1945
}

\subsection{The "Reorganization" of the Institute under the Banner of Phenogenetics, 1938-1942}

\subsubsection{Preliminary Considerations in the Years 1938/42}

On March 8, 1940, Eugen Fischer wrote a long, confidential letter to Otmar von Verschuer, director of the Institute for Genetic Biology and Race Hygiene at the University of Frankfurt at that time. In this letter Fischer expressed critique - and certainly also self-critique - about the scientific development of his institute since the mid-1930s.

At first glance this critical assessment seems surprising. The KWI-A had profited considerably from the genetic and race policy of the National Socialist regime. Money flowed abundantly, research projects received generous support, the expansion of the institute proceeded. As the deputy chairman of the Medical Biology Section of the "Academic Council" of the KWG, and even more so as a member of the Expert Committee for "Anthropology and Ethnology" of the Emergency Association of German Science and the Reich Research Council, respectively, the position Fischer held within his area of expertise was central in terms of research strategy. ${ }^{1}$ The political prestige and social recognition of the KWI-A, and the scientists working there increased constantly. Fischer himself received a number of honors and accolades in the Third Reich, of which his election to membership in the Prussian Academy of Sciences in 1937 was the most important. Just a year earlier, in 1939, Fischer had been awarded the Goethe Medal for Art and Science. ${ }^{2}$

Yet in March 1940 Fischer was not satisfied with the development of the institute. The "Faustian bargain" he had entered into with the National Socialists entailed numerous additional duties for Fischer and his staff, as experts in political bodies, as assessors on the hereditary health courts, as evaluators, teachers, popular

\footnotetext{
${ }^{1}$ Lösch, Rasse, p. 273.

${ }^{2}$ Cf. the "Ehrenliste" ibid., p. 277.
} 
speakers for public lectures, as representatives of the new Germany at international congresses, all of which were performed at the cost of the scientific work. More serious was that the emphases of research had shifted as a consequence of the interconnections with politics - and not necessarily in the direction Fischer would have wished. In 1933, under pressure from Arthur Gütt and with a view to the genetic health policy of the new rulers, Fischer had placed the stress on genetic pathology. With Verschuer's departure in 1935, Fischer had ceased forcing genetic pathology research, although the projects in progress were continued, and the emphasis was shifted to strengthening genetic psychology instead. The dual course shift had the result that the research program was visibly fragmenting into unrelated, individual projects. Fischer recognized that the institute was in danger of losing its scientific focus. As he wrote in his letter to Verschuer of March 1940:

\begin{abstract}
I have been very concerned recently, even as long ago as a year or two before the war, that the institute is working, so to speak, "without a plan." That was not always the case. When you were here, our first major task was to elaborate and test the twin method, and with this method to set human genetics properly on its feet. And I believe we can say that we managed to do this. In this field only touching up should be necessary. Also quite important. The point is to fill in the quite significant gaps and deepen our knowledge. But some areas, for instance, normal morphological attributes, but also numerous diseases, have pretty much been exhausted for twin research. ${ }^{3}$
\end{abstract}

Here it becomes apparent once again that from the founding of the KWI-A into the second half of the 1930s, twin research had the function of a scientific paradigm for the institute, providing an ensemble of axioms and premises, concepts, theories and models, methods, tools, and model examplars, symbolic generalizations, and implicit valuations to guide research practice. That this paradigm no longer carried the research in Dahlem - as Fischer expressed clearly - had to do with more than just Verschuer's departure. Rather, the paradigm had exhausted itself. According to Thomas S. Kuhn, a paradigm shift occurs when the anomalies within a disciplinary system accumulate, that is, when the number of riddles that cannot be solved using the means of the normal science guided by the paradigm predominant up to that time increases at such a rate that the disciplinary system as a whole enters a state of crisis. ${ }^{4}$ And indeed, in the 1930s, twin research, which for several years had been considered the king's road of human genetics, as discussed above, reached its conceptual and methodological limits and became the target of criticism. What was sought was a new paradigm that opened up the perspective to solve problems the old one could not. Where should new impulses come from now? Fischer did not believe that the orientation of Verschuer's institute in Frankfurt could serve as a model for Dahlem:

You work more clinically in Frankfurt. I don't want that here. And perhaps it is correct that a pure research institute like the one here leaves the actual clinical matters to the university institutes, those for genetic biology and truly clinical ones. ${ }^{5}$

\footnotetext{
${ }^{3}$ Fischer to Verschuer, 8/3/1940, MPG Archive, Dept. III, Rep. 86 A (Münster), No. 9. Quotes and emphases added by hand to the original.

${ }^{4}$ Kuhn, Structure of Scientific Revolutions.

${ }^{5}$ Fischer to Verschuer, 8/3/1940, MPG Archive, Dept. III, Rep. 86 A (Münster), No. 9.
} 
Aside from the problem of demarcation from the university clinics and institutes working in the area of genetic pathology, Fischer probably foresaw that a clinical orientation of his institute would cause conflicts of competence with two other Kaiser Wilhelm Institutes: the Kaiser Wilhelm Institute for Brain Research, which, under the direction of Hugo Spatz since 1937, had turned increasingly to questions of genetic pathology in neurological disorders, mental illnesses and mental disability, and above all with the German Research Institute for Psychiatry in Munich under Rüdin. In Munich the very founding of the Department for Genetic Psychology had been taken as an affront, and the vehement exchange of blows concerning diabetes research in 1937 had shown that the two institutes were bound to get in each other's way in the field of genetic pathology. Against this background it seemed to Fischer, who had never worked purely clinically anyway, that a onesided orientation of research at the KWI-A toward genetic pathology - while neglecting Fischer's own original research field, the heredity of "normal" (not pathological) attributes - to be a strategic mistake, although he certainly held genetic pathology to be a constitutive element of his further research strategy.

But as Fischer established self-critically, his own research in the field of physical anthropology did not have the potential to constitute a new paradigm either:

For my own (personal) work, of course, I have plans that include my doctoral students. The one project is, as for many years, the research of the conditions for the shape of the skull; the other the bastardization problem. But these two topics cannot fill an entire institute, and assistants from the field of medicine, who want to pursue practical activity later, cannot, or at least not exclusively, be set to work on such subjects. And since you have been gone I feel both a great void and a sense of being orphaned. ${ }^{6}$

The Department for Human Genetics had been dissolved in 1935, as mentioned above. In addition to the Department for Anthropology led by Fischer himself, the only pillar of the institute that remained was the Department for Race Hygiene headed by Fritz Lenz. However, Fischer lamented, it could hardly be expected that new impulses would come from there.

For Lenz does not take care of any of this. He works without planning, assigns themes to pupils without a plan. These themes are individual questions of a genetic pathology or race hygiene biological nature, which occur to him while editing Baur-Fischer-Lenz or during his critical perusal of the literature.?

Such occasionally arising, isolated themes were to be pursued in the future as well, and the work of the Department for Genetic Psychology under Kurt Gottschaldt was to be continued according to Fischer's wishes.

But as to the main point, such an institute needs an ambitious plan. And because I can not receive it from Lenz's sphere of interest, let alone through his initiative, I do it alone. But such a plan is conceived for a number of years, and certainly - not only presumably longer than I will be in office here. Because I do not doubt in the least that you will be my successor someday, in truth I would like to begin with a long-term plan only if I have the hope that you like it enough to pursue it further.

\footnotetext{
${ }^{6}$ Ibid. In parentheses: handwritten edition. Emphases added by hand to the original. ${ }^{7}$ Ibid.
} 
I once told you in passing that I would like to set up a collection of work for the genetic biology of humans. I will do this in any case. But what I would most like to do now, or at least right after the war, is to begin work in this sense as well. I am thus thinking of an ambitious phenogenetics. ${ }^{8}$

With this the decisive catchword had fallen. It is important to keep in mind that the idea was not new and that this was not the first time Fischer had discussed it with Verschuer. Rather, phenogenetics was already structured within the concept of anthropobiology, which had been one of the institute's founding fields. From 1938 on, Fischer - in lively intellectual exchange with Verschuer - worked intensively to elaborate a concept of phenogenetics. The impetus had come from the zoologist Alfred Kühn (1885-1968), since 1937 Deputy Director and then Director of the Department for Animal Genetics at the Kaiser Wilhelm Institute for Biology. Kühn had turned to Fischer in February 1938 in his capacity as chairman of the German Society for Genetics, in order to discuss with him the thematic conception of a congress to be held in fall 1938. While the zoology and botany sections were to deal with topics from the area of "Chromosome Structure, Genes and Effective Agents," Kühn proposed the general topic "Phenogenetics" for the human genetics section. In the conversation between Kühn and Fischer, the initial idea was to deal with the topic in three separate talks about "normal," "pathologic" and "psychopathic" attributes, whereby Kühn placed particular value on supplementary demonstration cases. Fischer warned "that human genetics in most cases [does not yield] results as clear [...] as the experimenters are accustomed to from their material." Verschuer, with whom Fischer consulted immediately, confirmed this:

We are, of course, still far from being able to perform phenogenetics of the kind Kühn conducts on the flour moth. The objective lies clearly before us, and we are seeking to move forward by combining research on the history of development and pathogenetics with pure genetic analyses. At first we must be content to perform causal analysis of the phenotypical manifestations of variation. If phenogenetics is thus conceived in this more humble sense, I consent to the topic. I also think it is the most current one. ${ }^{10}$

Verschuer also agreed with the "tripartition" of contents. It was out of the question that Fischer himself would give the talk about normal morphological and physiological attributes - Kühn had also advocated this solution, solely by virtue of the works on the spinal column he had cowritten or initiated. Supplementary demonstrations, Verschuer wrote, could be presented by Fischer's staff members Wolfgang Abel and Engelhardt Bühler. The second talk about "pathologic morphological and physiological attributes, that is, the entire area of pathology with the exception of psychiatry," Verschuer allowed, would "certainly appeal" to him, yet due to his workload he could not take it on. In his stead he proposed his chief physician Ferdinand Claußen ${ }^{11}$ and offered to "advise [him] in every way in the selection of

\footnotetext{
${ }^{8}$ Ibid.

${ }^{9}$ Fischer to Verschuer, 8/2/1938, ibid.

${ }^{10}$ Verschuer to Fischer, 10/2/1938, ibid. The following quotes also come from this letter.

${ }^{11}$ As an alternative to Claußen, Verschuer suggested Friedrich Curtius. "The pupils of Rüdin seem to me to be somewhat one-sided specialists."
} 
examples and in working through the material, especially with regard to the clinical side." He was also willing to add on to Claußen's presentation "a demonstration or two. We have abundant material at our disposal, and during the editing of the chapter 'Anomalies of the Shape of the Body' for 'Baur-Fischer-Lenz' the scientific problems just keep coming." The third talk about "normal psychology and psychopathy including psychiatry" was to be held by Kurt Gottschaldt, director of the Genetic Psychology Department at the KWI-A. ${ }^{12}$ Verschuer's proposals were implemented, and so the human genetics section at the Congress of the German Society for Genetics, which finally took place in Würzburg in September 1938, was firmly in the hands of the KWI-A and its daughter institute in Frankfurt - Verschuer had been responsible for directing the section. ${ }^{13}$ The three talks by Fischer, Claußen and Gottschaldt were published immediately - in greatly expanded versions - in the Zeitschrift für induktive Abstammungs- und Vererbungslehre, the journal founded by Erwin Baur in 1908 which was thus the oldest journal in the world on the field of genetics. ${ }^{14}$ Above all Fischer's "Attempt for a Phenogenetics of the Normal Attributes of Humans," one of the few publications by Fischer from the second half of the 1930s that was scientific in the strict sense, and the most extensive by far, constituted the conceptual basis for the restructuring of the KWI-A at the start of World War II.

\subsubsection{Phenogenetics: A New Paradigm}

What did the term phenogenetics mean to Fischer, and where did the term and its content come from? As related in detail in previous sections, in the 1920s, German genetics - in the sense of the developmental genetics - had opened up to evolutionary biology, developmental physiology, and embryology. One of the earliest attempts to close the gap between genetics and developmental physiology was the "phenogenetics" introduced by the zoologist Valentin Haecker (1864-1927) of Halle in $1918 .{ }^{15}$ In contrast to experimental embryology, which proceeded from the

\footnotetext{
${ }^{12}$ Verschuer suggested calling upon Luxenburger, Stumpfl, and Conrad of the German Research Institute for Psychiatry to present supplementary demonstrations.

${ }^{13}$ In his memoirs, Verschuer emphasized the scientific yield of this conference less than its special atmosphere: it was completely dominated by the effect of the "Sudetenland crisis": "The leaden weight of an impending storm lay on everyone's mood. One listened to the scientific lectures only as if from a great distance. In one session dealing with the topic of the phenogenetics of humans [...] I had to preside. Every movement was mechanical, as if the scientific thoughts moved themselves along in the same old groove, while emotional life was occupied completely by the impending war. I had to leave the congress early and return to Frankfurt to stand ready for soldierly disposal." Verschuer, Erbe - Umwelt - Führung, "Professor in Frankfurt (1935-1942)" section, p. 16, MPG Archive, Dept. III, Rep. 86 A, No. 3-1. Cf. Geyer, Würzburger Vererbungskongreß.

${ }^{14}$ Fischer, Phänogenetik; Claußen, Phänogenetik; Gottschaldt, Phänogenetische Fragestellungen.

${ }^{15}$ Haecker, Eigenschaftsanalyse; idem., Aufgaben der Phänogenetik; idem., Aufgaben und Ergebnisse (here, p. 100, Haecker indicated that - aside from his own doctoral students -17
} 
fertilized egg to follow the further development of an organism, this "History of Development Analysis of Attributes" (Entwicklungsgeschichtliche Eigenschaftsanalyse) started with the finished phenotype and drew conclusions about the effects of the genotype. Still quite bound up in the descriptive methodology of the nineteenth century, Haecker's phenogenetics did not survive much past the early death of its founder in 1927. In the late 1930s it could be regarded as out of date, and the question arises as to why Fischer referred explicitly to Haecker in 1938. Upon closer observation, however, it becomes apparent that Fischer took over from Haecker little more than the term phenogenetics. In content he referred instead to Richard Goldschmidt, who had submitted a far more modern version of a genetics based on the history of development in his work Physiologische Theorie der Vererbung ("The Physiological Theory of Genetics") published in $1927 .{ }^{16}$ Fischer referred to this work explicitly, albeit in a rather concealed location. It appears that in the conceptual-programmatic sections of his talk, especially the formation of concepts, he was reluctant to use Goldschmidt as a basis, for Goldschmidt, who had been a Deputy Director and the head of the Department for Animal Genetics of the Kaiser Wilhelm Institute for Biology (and, as mentioned above, also a member of the Board of Trustees of the KWI-A), had been forced into emigration. In fact, Goldschmidt's successor Kühn had urged Fischer in this direction when he suggested the framework topic for the human genetics section.

The scientific object of the newly sketched field of research was phenogenesis. Under this, Fischer understood the development "between the genome generated upon the fertilization of the egg and the complete phenome." Instead of the conceptual pair "genotype/phenotype" introduced by Wilhelm Johannsen (18571927), Fischer proposed using the terms "genome" and "phenome" to differentiate between the genetic type and the way in which it is manifested. The process of phenogenesis, Fischer continued, was influenced on the one hand by the effects and reciprocal actions of the genes, on the other hand by "a multiplicity of environmental and influencing conditions," which he designated with the term "peristasis." Peristasis was, as Fischer emphasized expressly, more broadly conceived than the concept of "environment," which generally only covered the influences exerted on an organism after its birth, like nutrition, light, chemical substances, trauma, movement, and rest. Fischer also counted the various developmental stages of an organism like youth, maturity and age, then pregnancy and illness, and finally "the mental" as environmental factors. According to Fischer these factors mainly affected the phenogenesis of attributes that do not manifest themselves until later in life. Peristasis included not only these factors, but all prenatal influences, such as the metabolism between the fetus and the maternal organism through the placenta, but also pressure, tension, or swelling caused by the position of the unborn child which can influence its development, as well as the regulation processes effective in the development of the embryo. Peristasis was thus a collective

predominantly German-speaking biologists had taken over his concept and usually the term phenogenetics as well); idem., Bestrebungen. Cf. Harwood, Styles, pp. 52-55.

${ }^{16}$ Goldschmidt, Physiologie. 
term for all factors affecting phenogenesis that did not lie directly in the genes. Fischer emphasized that the "series of forces" triggered by genome and peristasis do not simply complement each other cumulatively, but are related in a very complex system of interdependence and synergy that is subject to constant change. The task of phenogenetics was thus to disentangle the networks of effects exerted by genes and peristatis for analytical purposes and to pursue their effects and interactions all the way up to the complete phenome. Methodologically this task was to be approached through a combination of classical genetics, embryology and developmental mechanics, anthropometry and clinical diagnostics, whereby Fischer repeatedly emphasized the utility of combining the animal model with observation of humans.

At this juncture it is worth taking another look across the Atlantic. Since the early 1930 s the interest of geneticists there, too, encouraged in part by the Rockefeller Foundation, shifted increasingly to physiological genetics. In sharp competition with the research group around Kühn, the geneticist George Beadle (1903-1989) and the embryologist Boris Ephrussi (1901-1979) worked in Pasadena to bridge the gap between classical genetics and developmental physiology. They may have lost the race to identify kynurenin, but in the early 1940 s Beadle and Edward Lawrie Tatum (1909-1975) succeeded in finding evidence for the "one-gene-one-enzyme" hypothesis they had advanced during experiments on the neurospora mold - a pioneering success, for which they were awarded the Nobel Prize in 1958. While this had directed attention to the effects of genes, the embryologist, geneticist, and evolutionary biologist Conrad H. Waddington broadened the horizon in 1942 with his concept of "epigenetics," in which he - in nearly the same words as Eugen Fischer 4 years previously, and also with reference to Valentin Haecker's phenogenetics - shifted the complex developmental processes from the genotype to the phenotype into the focus of interest:

For the purposes of a study of inheritance, the relation between phenotypes and genotypes can be left comparatively uninvestigated; we need merely to assume that changes in the genotype produce correlated changes in the adult phenotype, but the mechanism of this correlation need not concern us. Yet this question is, from a wider biological point of view, of crucial importance, since it is the kernel of the whole problem of development. Many geneticists have recognized this and attempted to discover the processes involved in the mechanism by which the genes of the genotype bring about phenotypic effects. The first step in such an enterprise is - or rather should be, since it is often omitted by those with an undue respect for the powers of reason - to describe what can be seen of the developmental processes. For inquiries of this kind, the word "phenogenetics" was coined by Haecker. ${ }^{17}$ The second and more important part of the task is to discover the causal mechanisms at work, and to relate them as far as possible to what experimental embryology has already revealed of the mechanisms of development. We might use the name "epigenetics" for such studies $[\ldots] .{ }^{18}$

\footnotetext{
${ }^{17}$ In this Waddington referred to Haecker, Eigenschaftsanalyse.

${ }^{18}$ Waddington, Epigenotype, quote: pp. $18 \mathrm{f}$.
} 
The concept of epigenetics has since undergone a series of transformations, but has managed to persist - off the track of mainstream genetics. Indeed, in the most recent bioethical debates many hopes are pinned on the concepts of epigenesis and epigenetics, as they promise to break open the "reductionist approach" of classical genetics.

From Fischer's perspective, the new paradigm of phenogenetics offered several advantages. First, it permitted a whole series of projects that had been performed at the KWI-A and its periphery in the 1930s, which were rather loosely connected, to be related to each other under a complex of issues that applied to all of them. This was true first of all for a great number of works by Wolfgang Abel, Georg Geipel, Bernhard Duis, and others on the methodology of dermatoglyphics, that is, the genetics of epidermal patterns, on the increased frequency of characteristic epidermal ridge patterns for certain human races, and on the connections between defective epidermal ridge patterns and physical disability or mental diseases. Fischer attributed a central position in the field of phenogenetics to the works of his earlier pupil Konrad Kühne on the genetics of the variations of the spinal column, which had been continued at the KWI-A in Maria Frede's work on rats. Great value was also ascribed by Fischer to the embryological studies by Rita Hauschild on the skulls of Negroid and Caucasion fetuses and by Baeckyang Kim about race differences in embryonic pig skulls - even at the time, both studies were understood explicitly as contributions to phenogenetics. ${ }^{19}$ According to Fischer, various other works originating from the KWI-A on morphology and the genetics of human hair growth, the auricle, on asymmetries in body structure, on the heritability of stature, on miscegenation and on genetic pathology could also be classified under the umbrella of phenogenetics.

On the other hand, second, the paradigm of phenogenetics demarcated a broad research area that the existing works had barely begun to cover, and which was underdeveloped in terms of both breadth and depth. At the congress in Würzburg, Fischer established retrospectively in 1940, it became apparent that the "true course of development" was only really known for coloboma, the congenital gap in the eye area due to the insufficient closure of the fetal eye cleft, on the iris, choroid, lens, or lid.

Just as we have a history of development of every normal organ, we should have an exact history of development of every hereditary disease. Everything has yet to be done here.

Much is also missing on the heredity of normal things. ${ }^{20}$

The paradigm of phenogenetics was thus open enough to provide the foundation for a comprehensive research program with questions covering all of its areas.

A further advantage of turning toward phenogenetics was that, third, the research focused on a form of human genetics that was compatible with the orientation of

\footnotetext{
19 "We are currently working on breeding embryonic material for the entire heredity of vertebral varieties. I had the idea for this and took the first steps back in 1933, when Miss Frede was working on the first rat embryos, then later, when Kim examined the embryonic pig skulls and Hauschild the Negro skulls. That was true phenogenetics. But that is really everything." Fischer to Verschuer, 8/3/1940, MPG Archive, Dept. III, Rep. 86 A (Münster), No. 9.

${ }^{20}$ Ibid.
} 
developmental genetics predominant in German animal and plant genetics at the time. ${ }^{21}$ In his lecture in Würzburg, Fischer referred to the work of the developmental physiologist Hans Spemann (1869-1941), who had performed experiments on amphibian embryos in the 1920s, which proved that some parts of the embryo, such as the primitive roof of the mouth and the eye socket, act as "organizers" to "induce" the formation of other structures in the embryo. Spemann had not attempted to explain the inductive effect of the organizers by investigating the genes. Alfred Kühn made more progress on this with his experiments on the flour moth Ephestia kühniella, to which Fischer referred several times in his comments. Kühn had found a mutant Ephestia with red eyes rather than the usual black ones, and his doctoral student Ernst Wolfgang Caspari (*1909) was able to prove that, by injecting tissue from wild moths into the larvae of the red-eyed mutants, the eye color of the mutant could be adapted to that of the wild type. A substance missing in the mutants was apparently added through the injection. Genes, it was concluded, obviously work through enzymes. If an enzyme is lost through mutation, this can block the transformation of a certain substance into another. Through artificial implementation of the missing enzyme - in the case of the light-eyed Ephestia this was the tryptophan derivate kynurenin, as two assistants to Adolf Butenandt (1903-1995), Erich Becker and Wolfhard Weidel, were able to prove - it was possible to generate a "phenocopy" of the wild type, an idea that apparently fascinated Eugen Fischer. Yet, even more often than he referred to Kühn, Fischer brought up Hans Nachtsheim's work on the genetic pathology of rabbits.

Consequently, in March 1940 Fischer presented to Verschuer the idea of bringing Nachtsheim to the KWI-A as director of a new Department for Experimental Genetic Pathology, in order to supplement his studies on the phenogenesis of genetic illnesses of the rabbit with "parallel studies of a clinical nature on humans" as a way of connecting animal and human genetics. Fischer's remark, "I have no idea whether he [Nachtsheim] would want to," indicates that Fischer had not yet negotiated with Nachtsheim at this time. He first wanted to await his designated successor's opinion of this plan, and further of the plan associated with it - quite explosive in terms of institute politics - to "completely dismantle" the Department for Race Hygiene headed by Fritz Lenz, as "race hygiene could then be taken care of in the university institute." In other words, the KWI-A was supposed to give up race hygiene as a field of research, and Fritz Lenz gradually be forced to the margins.

Fischer closed his letter to Verschuer with the request that he not answer in writing, for he hoped that there would be opportunity at Easter 1940 to discuss the complex of topics in person. Hence we know nothing about Verschuer's immediate reaction. Yet the further course of events suggests that Verschuer fully agreed with

\footnotetext{
21 "Drosophila genetics has been our pacemaker until now. This appears to be nearly over; it no longer teaches us anything new." (ibid.). This can be interpreted as a renunciation of the drosophila genetics at the Genetic Department of the KWI for Brain Research under Nikolaj V. and Elena A. Timoféeff-Ressovsky. Of course, it must be remembered that the Timoféeff-Ressovskys, before turning to the genetics of mutations and populations, made significant contributions to developmental genetics. Cf. Harwood, Styles, pp. 55 f.
} 
the research plan developed by Fischer. The two most important conceptual works by Verschuer from the year 1939 - his lecture about "The Genotype of Humans" to the main assembly of the Kaiser Wilhelm Society in Breslau on May 24, 1939 and his presentation "On the Genetic Analysis of Humans" for the 7th International Congress for Genetics in Edinburgh ${ }^{22}$ (which he was not able to give himself due to the early departure of the German delegation, but was read to the audience on August 28, 193923) - first of all show that Verschuer picked up on Fischer's impulses immediately, and also illuminate the background against which Fischer's and Verschuer's new conception must be viewed: over the course of the 1930s, classical Mendelian genetics was undergoing a dramatic and extensive process of transformation. The idea generally accepted up to that time, that every attribute was simply transmitted as dominant or recessive, monofactorial genetic information, did not hold up to the results of mutation research, population genetics and developmental physiology. Thus Mendelian genetics was giving way, in the words of the day, to "higher Mendelism, ${ }^{24}$ which presumed much more complicated mechanisms of heredity. It became generally accepted that genes could not be observed in isolation from each other, but only in the context of the genotypical setting - the effect of one gene was always influenced by other genes, and even by the genome as a whole. It was acknowledged that the genes on the chromosomes are not just pearls strung on a string in any order, but that the effect of each gene depends on its position in the genome. With increasing clarity it became apparent that these mutual effects within the genome, but also prenatal influences on the intra-uterine environment during maturation of the embryo, and even influences from the external environment, had modifying effects on the way genes were manifested in the process of phenogenesis. The phenomenon of "weak genes" made its first appearance. The team of the KWI for Brain Research around Nikolaj Vladimirovich TimoféeffRessovsky and Elena Aleksandrovna Timoféeff-Ressovsky had attempted to grasp the phenomenon of the variations in how such genes were manifested in terms of the three concepts "penetrance" (the frequency with which a genetically conditioned attribute develops in the phenotype), "expressivity" (the degree to which it develops) and "specificity" (the nature of its development depending on the part of the body the gene must affect for this development) - a terminology that was picked up everywhere, including by Fischer and Verschuer. It was acknowledged that in many cases a single gene is involved in the development of several attributes (pleiotropy) and, inversely that the development of a single attribute can be influenced by multiple genes (polygeny). Furthermore, the advances in differential diagnostics showed that one and the same clinical picture can be caused by both genetics and environment (heterogeny). Finally, the results from radiation and

\footnotetext{
${ }^{22}$ Verschuer, Erbbild vom Menschen; idem., Bemerkungen zur Genanalyse.

${ }^{23} \mathrm{Cf}$. Roth, Schöner neuer Mensch, pp. 11-13.

${ }^{24}$ The term was coined in 1934, probably by Günther Just, and picked up on immediately by Verschuer. Cf. Just, Probleme des höheren Mendelismus; Verschuer, Genetic pathology, 2nd edn., p. 7. Cf. Weß, Humangenetik, pp. 173-176.
} 
population genetics suggested that the rates of mutation were higher than originally presumed, but that the heterozygotic mutants did not become visible because the gene did not necessarily develop in their phenotype. ${ }^{25}$

Verschuer, as his lecture texts indicate, was completely up to date in the contemporary specialized discourse; his institute in Frankfurt had even made a significant contribution to theoretical research in human genetics in 1938, when one of Verschuer's staff members, Bruno Rath, on the basis of a family study of a "bleeder clan," succeeded in finding the first proof of a crossing-over (exchange of genes or gene sections through the recombination of chromosome fragments) in humans. ${ }^{26}$ Against the background of higher Mendelism, Verschuer was fully aware that the previous conception of human genetics required greater differentiation, an expanded catalog of questions, and a larger arsenal of methods. Fischer's suggestions could hardly have come at a better time.

In his Breslau lecture Verschuer first related the success story of human genetics. By that time around 1,000 of the estimated 30,000-60,000 genes in humans were known, along with several hundred hereditary diseases, for most of which the heredity had been illuminated. "The human being is an object of the human sciences that has been examined in manifold ways [...]." Yet there remained much to be done. Genetic analysis could no longer be content with using the methods of family and twin research to reveal the dominant or recessive mode of inheritance of a gene. On the contrary, a whole bundle of new questions had to be posed:

What meaning does a gene have for development? At what point in time and at what location does it become visible? What changes in the tempo or in the chronological sequence of certain developmental processes does it cause? Is there the possibility of preventing pathological consequences? How do the individual genes work together? Do certain genes reveal peculiarities according to the race or constitution of the individual human being??

In summary it can be stated that the cognitive advances in the field of human genetics in the 1930s practically forced an expansion of classical Mendelian genetics. Theoretically, expansion was conceivable in various directions - from mutation research, to the "synthetic theory of evolution," all the way to molecular genetics. However, considering its own resources, and also with a view to the orientations of competing research institutions, the paradigm of phenogenetics seemed most promising for the KWI-A. Moreover, it was quite advantageous for Verschuer, because his personal research interest in clinical genetic pathology dovetailed perfectly with the new paradigm. As such - another point that must not be overlooked - it was practically tailored to Verschuer and provided him a weighty advantage over Lenz as a potential rival for Fischer's succession.

\footnotetext{
${ }^{25}$ This final aspect is placed all too strongly in the foreground by Roth, Schöner neuer Mensch, esp. pp. 22, 25, 39f., 54-56.

${ }^{26}$ Rath, Rotgrünblindheit. Verschuer reported about this before the fact in January 1938, to the Frankfurt Medical Society. Cf. Verschuer, Erster Nachweis von Faktorenaustausch; idem., Frage des Faktorenaustausches.
}

${ }^{27}$ Verschuer, Erbbild vom Menschen, pp. 5 f. 


\subsubsection{The Succession Issue}

At this juncture our discussion turns to the thesis by Niels C. Lösch, who goes into great detail about the changes that took place under the banner of phenogenetics at the KWI-A in the years 1938-1940. However, because he is fixed too one-sidedly on personnel-policy strategies, he interprets the development as a kind of "false label" designed to "prepare the ground for Verschuer." 28 There is no question that Fischer, who celebrated his 65th birthday on June 5, 1939, had been building up his pupil and friend Verschuer as his successor for a long time already, and that the establishment of the new paradigm of phenogenetics was linked intimately with Verschuer's person. It is also indisputable that Fischer had long since begun taking precautions to nip in the bud any aspirations Fritz Lenz might have for the post of the institute director - although, it must be added, there are no indications that Lenz pursued ambitions in this direction.

In September 1934, when Fischer, much to his dismay, learned of the plans to call Verschuer to Frankfurt, he immediately began considering whether the chair in Frankfurt could serve Verschuer as a stepping stone on the path to succeeding Fischer. In November 1938 - that is, while the Würzburg lecture was being printed - Fischer then set the course for the future development of the institute in a talk with Ernst Telschow, General Secretary of the Kaiser Wilhelm Society: "For the case of his departure upon reaching the age limit in 3-4 years, Professor Fischer nominated Professor Verschuer of Frankfurt as his successor."29 In March 1939 Fischer informed Verschuer of this conversation, after congratulating him for the most recent evidence of the Kaiser Wilhelm Society's favor - "exchange professor in London! Speaker at the general meeting [...] Some time ago Mr. Telschow and I had a long talk, during which we also discussed you in great detail. He is informed for now and for the future and was entirely of my opinion." ${ }^{30}$ In his exchange of opinions with Telschow, Fischer had indicated that he rejected the plan to set up a major institute for anthropology at the Friedrich Wilhelm University in Berlin, advising Telschow "to pare this institute down considerably and plan it [...] merely as an institute for race hygiene. As director Prof. Lenz would then be suitable on a full-time basis." ${ }^{31}$ This is yet another indication of Fischer's strategy of strengthening Lenz's role at the university and pushing him to the margins of the KWI-A, even though at this point in time he was still advocating Lenz's appointment as

\footnotetext{
${ }^{28}$ Lösch, Rasse, p. 374.

${ }^{29}$ File note by Telschow about a meeting with Fischer on 18/11/1938, 21/11/1938, MPG Archive, Dept. I, Rep. 1 A, No. 2399, p. 130.

${ }^{30}$ Fischer to Verschuer, 9/3/1939, MPG Archive, Dept. III, Rep. 86 A (Münster), No. 9. The KWG had appointed Verschuer for an exchange of professors with the Royal Society in London, which took place in June 1939. Cf. Verschuer, Erbe - Umwelt, Führung, "Professor in Frankfurt (19351942)" section, pp. 17-20, MPG Archive, Dept. III, Rep. 86 A, No. 3-1.

${ }^{31}$ File note by Telschow about a meeting with Fischer on 18/11/1938, 21/11/1938, MPG Archive, Dept. I, Rep. 1 A, No. 2399, p. 130.
} 
deputy director of the institute. In July 1940 - by this time Fischer had coordinated his plans for reorganizing the institute with Verschuer - the departing director expressed himself more clearly to Telschow:

In repetition of earlier conversations, Prof. Eugen Fischer designated Prof. von Verschuer in Frankfurt as a suitable successor. It would then be appropriate to grant Prof. Lenz the title of "Director" because of his age, without entrusting him with the direction of the institute. Prof. Fischer held it even more appropriate to transfer Prof. Lenz to the Institute for Race Hygiene at the University of Berlin, which - at present consisting of two rooms in the Hygiene Institute - would have to be expanded..$^{32}$

Then, in October 1940 Fischer got down to brass tacks:

Within his institute Prof. Fischer wants to have a special Institute for Race Hygiene under Prof. Lenz, who thus would receive the title of "director," as it were, but without becoming Prof. Fischer's deputy. On the contrary, Prof. Fischer wants to prevent this, in consideration of the proposed succession to his position by Prof. von Verschuer. ${ }^{33}$

At the same time Fischer conveyed his intention to rename his institute. In the future it was to be called the "Kaiser Wilhelm Institute for Genetic and Race Science" (Kaiser-Wilhelm-Institut für Erb- und Rassenkunde) and thus in its very name express the demarcation from race hygiene. ${ }^{34}$

Fischer's attitude toward race hygiene was expressed quite clearly 1 year later, in October 1941, when he argued - much more aggressively than Lenz, who lacked the requisite tact - for the expansion of the university's Race Hygiene Institute:

$[\ldots]$ today race hygiene [has] become a state policy, it no longer requires propaganda. Race hygiene is a required lecture and examination subject for medical students. I can no longer recognize race hygiene as such as a research subject; rather, the research subject is its substrata, first of all human genetics and then demographics. [...] For these reasons I hold the expansion of a university institute for race hygiene at the greatest German university to be a quite self-evident necessity. [...] Because of the auspicious historical development in the Third Reich, at the Kaiser Wilhelm Institute this race hygiene department must be dismantled rather than expanded. ${ }^{35}$

Race hygiene, as the theory of the practical implementation of the knowledge in human genetics and demography, one could summarize Fischer's argument, had a right to exist at the KWI-A during the Weimar Republic, but in the Third Reich race hygiene seemed to him unnecessary baggage that distracted the institute from its theoretical research. By no means did Fischer want to force Lenz out of the institute entirely - as an astute critic he made a major contribution to the conceptual foundations

\footnotetext{
${ }^{32}$ File note by Telschow about a meeting with Fischer, 24/7/1940, ibid., p. 141.

${ }^{33}$ File note by Telschow about a meeting with Fischer, 18/10/1938, ibid., p. 142.

${ }^{34} \mathrm{Cf}$. also the undated (written around April 1940) paper by Fischer, "Der Name des Institutes" ("The Name of the Institute"), MPG Archive, Dept. III, Rep. 86 A (Münster), No. 9 (here Fischer advocated renaming the institute to "Kaiser-Wilhelm-Institut für menschliche Erb- und Rassenforschung und Institut für Rassenhygiene" ("Kaiser Wilhelm Institute for Human Genetic and Race Research and Institute for Race Hygiene").

${ }^{35}$ Fischer to Reichsminister für Wissenschaft, Erziehung und Volksbildung, 20/10/1941, MPG Archive, Dept. I, Rep. 1 A, No. 2400, pp. 218-219 v, quote: pp. 218 v-219.
} 
of the research at the KWI-A. The fact that he did not want to see Lenz in the director's post concerned not only his lack of qualities as a science manager, and was not founded only in personal animosities between the two scientists - that, too - but above all Lenz was far too much a proponent of classical race hygiene, which Fischer did not believe had much potential for innovation.

The result is indisputable: Fischer machinated behind the wings in order to guarantee that Verschuer would be appointed director of the KWI-A and to prevent Lenz from offering himself as an alternative candidate. In contrast to Niels Lösch, however, this author advocates the thesis that the paradigm of phenogenetics was also, but by no means only a means to an end in order to prejudice an impending personal-policy decision. The realization of the newly developed research conception presupposed a kind of package solution: the new orientation of research in progress; opening up new areas of work, but also relinquishing areas that could not be fit into the new paradigm in a meaningful way; integrating scientists who fit into the new research profile; changes to the internal structure of the institute; the creation of an infrastructure to implement new methods in practice, and finally the solicitation of the additional financing these tasks would require. In the years 1938-1940 Fischer resolutely pushed ahead in all of these directions, but initially he met with considerable resistance.

\subsubsection{The Alliance Between Eugen Fischer and Leonardo Conti and the Decisive Board Meeting in 1941}

The first step turned out to be quite easy. In November 1938 Fischer submitted to the General Administration his plan to set up an external department of the KWI-A for tuberculosis research, in the TB hospital "Waldhaus Charlottenburg" in Sommerfeld near Beetz in the eastern Havel region, under direction of that institution's Directing Physician of the Surgical Department, Karl Diehl. Telschow indicated that there would be no problem providing the 3,000 RM needed to set up the outpost in the coming fiscal year, ${ }^{36}$ so that from 1939 on the KWI-A officially comprised four departments. Thus, the first phase of reorganization went off without a hitch.

But in July 1940, when Fischer submitted to Telschow his plan to found a Department for Experimental Genetic Pathology and asked for a budget increase of $10,000 \mathrm{RM}$ for this purpose, the general secretary was less forthcoming. An increase in financing, he replied to Fischer, probably would be impossible "as long as the war lasts." Apparently Telschow believed that the war would end in 1941, but he did not want to raise Fischer's hopes for more funding in that year, either. All the same, he announced that he would attempt to get Max Planck interested in the plan and encourage the provision of support from the Planck fund - a plan Planck rejected immediately upon Telschow's proposal. ${ }^{37}$

\footnotetext{
${ }^{36}$ File note by Telschow about a meeting with Fischer on 18/11/1938, 21/11/1938, MPG Archive, Dept. I, Rep. 1 A, No. 2399, p. 130.

${ }^{37}$ File note by Telschow, 24/7/1940, ibid., p. 141.
} 
This setback opened up a precarious phase in the reorganization of the institute, for the new Department for Experimental Genetic Pathology was to become one of the pillars supporting phenogenetic research, if not the supporting pillar. Fischer needed political protection to succeed in implementing his plan by circumventing the General Administration - but this strategy was also shaky, as Hans Nachtsheim was not exactly considered a convinced National Socialist. Nevertheless: Fischer sought and found the necessary patronage of a functionary located high in the machinery of the National Socialist regime: Leonardo Conti.

It was convenient that a connection to Conti already had been established, as mentioned above, albeit a loose one. In December 1936 Conti had taken over the duties of the Medical Councilor of Berlin. In this capacity he was entitled to a seat and vote on the boards of the KWI for Brain Research and the KWI-A. ${ }^{38}$ The KWI for Brain Research must have interested him less - in any case in November 1937 he appointed one of his closest staff members, Director of the Department for the Care of Genes and Race in the Main Health Office of Berlin, Dr. Theodor Paulstich $\left({ }^{*} 1891\right),{ }^{39}$ as his permanent representative on the board of this institute, although he reserved the right to participate in future board meetings himself. ${ }^{40}$ At first Conti did not have anything to do with the KWI-A, either - in the years from 1937 to 1940 no board meetings took place. Conti had since moved up to the pinnacle of civilian health care: In April 1939 Hitler had appointed him as Director of the Main Office for National Health (Hauptamt für Volksgesundheit) and "Führer of Physicians of the Reich (Reichsärzteführer) and awarded him the title of Reichsgesundheitsführer ("Reich Health Leader"). In August 1939 Conti was also appointed State Secretary for Health Care in the Reich Ministry of the Interior and thus held all of the reins to steer the health matters of the state and the party. ${ }^{41}$

When Fischer endeavored to call a Board Meeting in January $1940,{ }^{42}$ he discovered that the previous chairman of the board, the premier of Saxony, Landeshauptmann Richard Otto, who had resigned his office as senator of the Kaiser Wilhelm Society in 1937 "in quite an abrupt manner," ${ }^{43}$ no longer considered himself to be in office. ${ }^{44}$ Because the General Administration - after consulting with Ministry Director Mentzel - did not regard the option of convincing Otto to remain on the

\footnotetext{
${ }^{38}$ Planck to Conti, 1/12/1936, MPG Archive, Dept. I, Rep. 1 A, No. 2403, p. 97. Max Planck solicited Conti's interest insistently: "Because the next sessions of the two boards will probably not be held until the coming spring, perhaps you might first find an opportunity to tour the two institutes."

${ }^{39}$ For a biography: Klee, Personenlexikon, p. 452.

${ }^{40} \mathrm{Cf}$. Schmuhl, Hirnforschung, p. 585.

${ }^{41}$ Kater, Conti; Labisch/Tennstedt, Weg, vol. 2, pp. 393-395.

${ }^{42}$ Fischer to Otto, 10/1/1940, MPG Archive, Dept. I, Rep. 1 A, No. 2403, pp. 108-109. Justifying the long interruption in board meetings, Fischer stated that there had "never occurred anything in particular and on the other hand the years were so eventful politically that one wanted to dispose of the time of such very busy men as sparingly as possible."

${ }^{43}$ Note by Telschow, 13/3/1940, on a letter by Fischer to Telschow, 30/1/1940, ibid., p. 102.

${ }^{44}$ Otto to Fischer, 23/1/1940, ibid., p. 107.
} 
institute's board to be opportune,${ }^{45}$ the question of a successor was raised, an issue Fischer and Telschow discussed in a meeting on March 17, 1940. Apparently Telschow's first suggestion here was Leonardo Conti, followed by Walter Groß. On the following day Fischer expressed his opinion on these suggestions in writing, declaring himself

completely agreeable to State Secretary Dr. Conti. I find this proposal of yours especially good. Of course, I would have nothing against Dr. Groß either; on the contrary, I would be pleased. But here my good personal relationship with Groß should not be the crucial factor. As a responsible representative of race policy, Groß is not as professionally close to the objectives of my institute as Conti, the Director of the Medical and Race Hygiene Department of the Reich Ministry of the Interior. The connection to him would presumably be more important to the institute; in any case, I already have a connection with Mr. Groß. ${ }^{46}$

It would soon become apparent that this was quite a clever move, especially since Fischer's strongest ally in the Nazi health leadership up to that point, Arthur Gütt, had been ousted by an intrigue in 1938 , clearing the way for Conti. ${ }^{47}$ But Fischer needed strong political protection to realize his ambitious - and exceedingly costly - plans for the reorganization of the institute under the banner of phenogenetics. On October 18, 1940 the General Administration of the Kaiser Wilhelm Society officially filed Fischer's proposal to offer Conti the Chairmanship of the Board of Trustees of the KWI-A. Fischer, it was recorded there, wanted "first to personally approach [Conti] on this matter." 48 This personal meeting between Fischer and Conti took place on November 12, 1940. It can be presumed that Fischer took this opportunity to relate his plans for reorganizing the institute to the new strong man in the health policy leadership and acquire his support. In any case Conti declared himself willing to accept the Chairmanship of the Board of Trustees and call a board meeting immediately, which was initially scheduled for December 11, 1940, but then postponed to January 9, 1941 due to conflicts with Conti's schedule. ${ }^{49}$

\footnotetext{
${ }^{45}$ Telschow to Fischer, 13/3/1940, ibid., p. 105.

${ }^{46}$ Fischer to Telschow, 18/3/1940, ibid., p. 106.

${ }^{47}$ The situation was all the more piquant because Gütt remained a member of the board. Conti proved magnanimous. He informed Fischer that he woud find it "especially nice if Gütt were retained on the board without further ado." Fischer, as he let Telschow know, had "the sense that he, too, wanted to avoid the appearance of having forced him [Gütt] out." Fischer himself spoke for Gütt's remaining on the board: "Since Mr. Gütt always had especially friendly interest in the institute and did much for it, I, too, would be very pleased if he remained on the board. Of course, this is only possible if, first, the number of members would not be raised to beyond that allowed by any existing regulation, and second, if Mr. Gütt is not expressly nominated as a representative of his ministry." (Fischer to Telschow, 13/11/1940, ibid., pp. 112-112 v.) Both were not the case, and consequently Gütt remained a member of the board. Telschow to Conti, 15/11/1940, ibid., p. 114. ${ }^{48}$ File note by Telschow, 18/10/1940, ibid., p. 111.

${ }^{49}$ Fischer to Telschow, 13/11/1940, ibid., pp. 112-112 v; file note by Miss Reinold, 14/11/1940, ibid., p. 113; Reichsgesundheitsführer, Verbindungsstelle Berlin to Geschäftsführenden Vorstand der Kaiser-Wilhelm-Gesellschaft, 22/11/1940, MPG Archive, Dept. I, Rep. 1 A, No. 2399, p. 143; invitation to board meeting on 11/12/1940, 28/11/1940, ibid., p. 145; telegram from Conti to the KWG, 7/12/1940, MPG Archive, Dept. I, Rep. 1 A, No. 2400, p. 171; Telschow to the members of the Board of Trustees of the KWI-A, 17/12/1940, ibid., p. 175.
} 
Attending this decisive meeting were - besides Fischer and Conti - from the side of state and party, Walter Groß and Hans Reiter, further the Medical Councilor of Berlin, Theobald Sütterlin ( $\left.{ }^{*} 1893\right) ;{ }^{50}$ and - as representative of the German Council of Municipalities - from Kiel, Dr. Klose; then the Inspector of the Army Medical Corps, General and Chief Staff Physician Siegfried Handloser; from the side of the Kaiser Wilhelm Society, General Secretary Ernst Telschow and Friedrich Schmitt-Ott; as representatives of science, finally, Fritz von Wettstein, director of the KWI for Biology, Otmar von Verschuer, and - as a guest - Fritz Lenz. ${ }^{51}$ The new chairman of the board set a political signal right in his welcome message, by pointing out
that activity and research of the Kaiser Wilhelm Institute for Anthropology, Human Heredity and Eugenics is of particularly great importance for the state and that it would be wrong if - as it sometimes seems - interest in the meaning of issues of the heredity and race of our nation were to decline. The new Greater Germany needs such knowledge urgently, the next generation of scholars in this area must be provided for.

The KWI-A as the "first and most outstanding" in this area must "serve and influence other institutes as a model." ${ }^{52}$ For this reason he, Conti, had accepted the Chairmanship of the Board.

Telschow's comments about the institute's budget plans from 1937 to 1940 turned out to be considerably more sober. Cuts of 20,000 RM from the regular budget had been necessary. The Reich Education Ministry was not able to refrain from this cut, "although the other ministries relevant for the Kaiser Wilhelm institutes had not made such cuts in consideration of the institute's acknowledged status as essential for the war." On this subject, Fischer elaborated that the institute had been able to "get over" the reduction due to the decline in the personnel budget, which had been eased as staff members were called up for military service, and thanks to savings in the material budget achieved by the "restriction of experiments" - although, Fischer emphasized, at "the detriment to scientific achivement." However, a glance at the revenue and expenditure accounts of the institute and the auditing reports of the KWG for the fiscal years 1939 and 1940 indicate that Telschow and Fischer painted an exaggeratedly gloomy picture of the institute's financial situation, which did not correspond to reality - more on this later.

The fifth agenda item, the "Director's Report about the Erection of a New Department for Experimental Genetic Pathology" was the sensation. In a speech explaining the entire framework of his proposal, Fischer submitted to the board his plans to reorganize the institute under the paradigm of phenogenetics. He started by

\footnotetext{
${ }^{50}$ For a biography: Klee, Personenlexikon, p. 616.

${ }^{51}$ The invitation was declined by Arthur Gütt, who had been promoted to State Secretary after his resignation; General Director Vögler, Senator of the KWG; and Ministry Secretary Rudolf Mentzel of the Reich and Prussian Ministry for Science, Training and Education.. Anlage 1 zum Entwurf des Sitzungsprotokolls, n.d., MPG Archive, Dept. I, Rep. 1 A, No. 2400, p. 185.

${ }^{52}$ Niederschrift über die Sitzung des Kuratoriums des KWI-A am 9/1/1941, ibid., p. 186 and 195, quotes: p. 186.
} 
providing detailed reasons why, in the middle of the war, he was submitting a research plan that pointed so far into the future. "The impending victorious conclusion of the war and the vast expansion of the Greater German Reich," Fischer claimed, would also pose "great and new challenges" to the research institutes. While until now the institutes directly important for the war had stood at the foreground, like those in the areas of physics, chemistry, and technology, in the "near future" all institutes that dealt with "questions of genetic health, race, human selection, environmental influences" would become more important, as these were "of consequence for leadership." One could never know "how pure scientific research, often of a seemingly completely theoretical nature, will work out in practice in the future." And thus, Fischer added somewhat less than humbly, there had been no way of knowing that his bastard studies of 1908 "one day could lay a foundation for race legislation." Until 1933 his institute had transformed "the young field of human genetics into a securely founded, widely developed theory, [...] which measured up to all demands of practical application in genetic consulting, genetic legislation, and as a basis of race theory and race legislation." ${ }^{53}$ By this time human genetic research was so far, Fischer proclaimed boastfully, that the genes for all essential normal and pathological attributes were known "in principle," the external phenotype could be related to these genes and "to some extent [...] the approximate scope of the environmental effects" was known. ${ }^{54}$ Then came the transition to Fischer's project of phenogenetics:

But one large area here is still quite dark. This is the question of how a given genetic disposition actually develops, how it works, how the gene "does its thing" (metaphorically speaking) to obtain the external appearance it is due. The path from the finished genetic disposition to the completely developed genetic attribute is still unknown. ${ }^{55}$

To legitimate the new research program, Fischer's argumentation stressed applicability. Phenogenetics was not only of "greatest scientific interest;" beyond this it promised "practical medical utility, the direction of which I can only hint at: differentiability of genetic conditions, prophylaxis for the genetically encumbered and corresponding marriage consulting, treatment of symptoms." 56

Embedded in this context of justifications, Fischer concretized his ideas for reorganizing the institute: First he emphatically championed the hiring of Hans Nachtsheim. For because "human embryonic material with certain pathologically determined genetic dispositions [could be] received only in very restricted amounts," one had to rely on "model experiments" on animals - and Nachtsheim's rabbit breeding was the most suitable model by far. The study of genetic conditions of the rabbit must be linked closely with clinical research.

\footnotetext{
${ }^{53}$ Anlage 2 zur Niederschrift über die Sitzung des Kuratoriums des KWI-A am 9/1/1941: Bericht über die Neueinrichtung einer Abteilung für experimentelle Erbpathologie, erstattet vom Direktor, ibid., pp. 187-193, quotes: p. 187.

${ }^{54}$ Ibid., p. 189.

${ }^{55}$ Ibid., p. 189f. (original emphases).

${ }^{56}$ Ibid., p. 191.
} 
In order to establish a connection with embryology, too, Fischer demanded, second, the erection of a "Central Genetic Biology Collection," which was to include fetuses, miscarriages, and organ specimens from humans and animals, especially from twins, with a view to race attributes, genetic illnesses, and deformities.

\section{Central Genetic Biology Collection \\ - Phenogenetics of Humans and Mammals -}

\section{Twins}

1. Fetuses and newborn bodies of identical twins (IT) and fraternal twins (FT)

2. Organs of child and adult IT and FT

3. Dual deformities of all kinds

4. Animal multiple births and dual deformities

II. European races: fetuses, newborns, and organs

1. Belonging to the races of the German nation

2. Belonging to other nations of Europe

3. Jews

III. Non-European races: as above

1. Asia

2. Africa

3. South Sea and Australia

4. America

5. Arctic region

IV. Genetic illnesses: fetuses, newborns, and organs from families with certain genetic pathological dispositions (later sorting by illnesses)

V. Domestic animal races: fetuses and organs

VI. Animal genetic illnesses: fetuses, newborns, and organs from breeds with certain genetic pathological dispositions ${ }^{57}$

Lösch advances the thesis that this central collection was "a new label for the institute's already existing, extensive collection of specimens." ${ }^{\text {" }}$ This is a misinterpretation, however - there had not been an embryologically oriented collection of fetuses, premature births and stillborn children at the institute before this time. Back in 1939 Fischer had placed appeals in the Deutsche Medizinische Wochenschrift and the Wiener Klinische Wochenschrift ("Vienna Clinical Weekly"), asking practical physicians to supply the institute with such material. ${ }^{59}$ Moreover, Verschuer

\footnotetext{
${ }^{57}$ Anlage zur Niederschrift über die Sitzung des Kuratoriums des KWI-A am 9/1/1941, MPG Archive, Dept. I, Rep. 1 A, No. 2400, p. 194.

${ }^{58}$ Lösch, Rasse, p. 373.

${ }^{59}$ Fischer, Menschliche Erblehre (Deutsche Medizinische Wochenschrift); idem., sic (Wiener Klinische Wochenschrift). On this also the undated draft for this appeal in the MPG Archive, Dept. III, Rep. 86 A (Münster), No. 9.
} 
pursued his predecessor's ambitious goals. A note (undated) in Verschuer's handwriting, presumably made in preparation for the negotiations with the KWG about his appointment, outlining his ideas about the future development of the institute, includes mention of "studies of human embryos from genetically diseased families" and the "collection of all cases of embryos of women whose pregnancies were terminated." ${ }^{\circ 0}$ In November 1942, Verschuer announced that "from inside the institute" he would "set in motion an organization according to which all women's clinics in Germany that perform abortions on genetically ill women would collect the embryos and deliver them to us." ${ }^{61}$ It was emphasized in particular that this could only be realized in collaboration with the "Reich Committee for the Scientific Recording of Serious Genetic and Genetically Disposed Conditions" (Reichsausschu $\beta$ zur wissenschaftlichen Erfassung schwerer erb-und anlagebedingter Leiden), that is, with the steering apparatus of the children's "euthanasia" that decided when pregnancies should be terminated on the basis of a eugenic, race, or ethical indication. ${ }^{62}$

Third, Fischer proposed a reclassification of the institute, which was to comprise five departments in the future:

- Department for Human Genetics (Fischer)

- Department for Genetic Psychology (Gottschaldt)

- Department for Race Science (Abel)

- Department for Experimental Genetic Pathology (Nachtsheim)

- External Department for Tuberculosis Research (Diehl)

- Central Genetic Biology Collection (Fischer)

The Department for Human Genetics dissolved in 1935 thus was to be restored, whereby Fischer - so to speak as a placeholder for his successor Verschuer - was to take over direction, just as he intended to take care of the Central Genetic Biology Collection himself. Fischer's own Department for Anthropology, on the other hand - renamed the Department for Race Science - was to be handed over to his pupil Wolfgang Abel, who then was also to be appointed Fischer's successor to the chair for anthropology at the University of Berlin. Further additions were those conceptualized in the context of the phenogenetic project: the Department for Experimental Genetic Pathology under Hans Nachtsheim, and the External Department for Tuberculosis Research under Karl Diehl. The Department for Genetic Psychology under Kurt Gottschaldt was to survive, whereby Fischer certainly assumed that it would be integrated into the program of phenogenetics as envisioned in Gottschaldt's talk at the Würzburg congress in 1938.

\footnotetext{
${ }^{60}$ Note by Verschuer, undated, MPG Archive, Dept. III, Rep. 86 B, No. 35.

${ }^{61}$ Verschuer to Stadtmüller, 16/11/1942, MPG Archive, Dept. III, Rep. 86 B, No. 36, pp. 26-29, quote: p. 27. Shortly thereafter Verschuer wrote that it was his desire "that material of human embryos collected according to this plan, which came from families with certain genetic illnesses (in particular physical deformities), should be studied by a specialized embryologist here at the institute." Verschuer to Starck, 30/11/1942, ibid., pp. 38-40, quote: p. 38.

${ }^{62}$ Schmuhl, Rassenhygiene, Nationalsozialismus, Euthanasie, p. 226.
} 
The only problem left was what should become of Fritz Lenz and his Department for Race Hygiene. This was to "remain linked securely to the whole," 63 but granted autonomy as an "Institute for Race Hygiene" under "Director" Fritz Lenz. To the Board of Trustees, Fischer sang Lenz's praises as a race hygiene pioneer. His strength lay in "positive suggestions, consulting with the responsible offices and oral and written instruction for students, physicians and the general public." Due to his "unique character," however, he could "not be considered [...] for the organization of the institute - a Fritz Lenz needs and has received unreserved relief and liberation from simple administrative and other institute activities in the interest of his theoretical work." 64 This was an extremely elegant formulation to express that Fischer held his department head to be unsuited for the post of director. The fact that Lenz attended the meeting and did not contribute to the discussion again confirms the impression that Lenz was altogether satisfied with the solution of an "institute in the institute" to which Fischer aspired. As the negotiations concerning the extension of the Race Hygiene Institute commencing later that year showed, Lenz pinned his hopes on his institute in the institute receiving its own budget and the right to hire its own staff, and, if this would be guaranteed, was even willing to relinquish any claim to a larger Institute for Race Hygiene at the planned University Clinic. ${ }^{65}$

In closing Fischer addressed the delicate issue of financing. He offered to finance the equipment and furnishings of the new Department for Experimental Genetic Pathology from institute funds, since the budget offered some latitude as a consequence of the restrictions to its work necessitated by the war. But additional finances were required for future operating costs, of which the personnel costs of 23,800 RM comprised the lion's share, as Fischer intended to hire not only the department head, but also an assistant with experience in anatomy, pathology, and histology, a technical assistant, and an animal keeper. Fischer estimated the additional material costs incurred by keeping animals at 10,000 RM, so that the future additional requirements amounted to $33,800 \mathrm{RM}$ annually, and Fischer wanted this sum in the form of a regular budget increase rather than as a special allocation. Finally, new land was also required for the construction of stalls for the rabbits, as no more room was available on the grounds of the institute.

Lösch presumes that such a comprehensive concept for the reorganization of the institute "was expected by hardly any of those attending," and that it was "new in this dimension" 66 even for Telschow. However, this is not the case. In fact, Fischer had sent a written draft of his talk to both Telschow and Conti back on December 3,

\footnotetext{
${ }^{63}$ Appendix 2 to the protocol of the meeting of the board of the KWI-A on 9/1/1941: Bericht über die Neueinrichtung einer Abteilung für experimentelle Erbpathologie, erstattet vom Direktor, MPG Archive, Dept. I, Rep. 1 A, No. 2400, pp. 187-193, quote: p. 192.

${ }^{64}$ Ibid., p. 189.

${ }^{65}$ Lenz to Reichsministerium für Wissenschaft, Erziehung und Unterricht, 31/7/1941, MPG Archive, Dept. I, Rep. 1 A, No. 2400, pp. 212-213 v.

${ }^{66}$ Lösch, Rasse, p. 371.
} 
1940 ${ }^{67}$ Telschow thus would not have felt "affronted," as Lösch presumes; rather, his comments about necessary budget cuts simply made clear once and for all whence the funds for the institute's modernization would not come. In so doing he had hit the ball back into the politician's court, where it was readily received. The game was rigged. For back on October 18, 1940, in the very same conversation between Fischer and Telschow in which Fischer officially made the proposal to give Conti the chairmanship of the Board of Trustees, and offered "to personally approach [the Reichgesundheitsführer] on this matter," Fischer had laid out to the General Secretary of the KWG his plan to equip the Department for Experimental Genetic Pathology, applied for a 20,000 RM increase in the personnel budget and $10,000 \mathrm{RM}$ in the material budget, and for an investment of 7,000 RM for the rabbit hutches. Fischer even brought with him to this meeting Hans Nachtsheim, who used the opportunity to negotiate with Telschow about his future salary. His appointment was slated for January 1, 1941. At the same time, according to a file note by Telschow, agreement was reached that the additional funds would "of course not be demanded in Professor Fischer's budget request until after conclusion of the war." 68 Since, as we showed above, Telschow did not believe that the war would be over within the year 1940, only one conclusion is possible: Fischer and Telschow had agreed to ask Conti for help in procuring the missing money from other sources for the time being. The course of the board meeting makes unmistakably clear that Fischer had done precisely this in his meeting with Conti on November 12, 1940, and that Conti had pledged his support.

Under Conti's direction, the board thus recorded in the protocol that the discussion had reiterated for the record "the special importance of the new department"; the provision of 33,800 RM was also "designated as urgently necessary." As regards the purchase or leasing of property for the rabbit hutches, the Reichgesundheitsführer pledged his "active support." Conti's confidant Sütterlin seconded the motion, signalizing the interest of Berlin's City Medical Administration and promising its support as well. At the same time, Sütterlin stated for the record "his satisfaction with the cooperation with the institute achieved in the working group with Dr. Diehl in Sommerfeld." Even should the hospital change leadership, Sütterlin ensured, Diehl's research could be continued without restriction. Finally, Army Medical Inspector Handloser also wished to have "his special interest in the work on rabbit tuberculosis" written in the protocol. ${ }^{69}$ Yet again it must be emphasized that Fischer's push surprised neither Conti and his right hand Sütterlin nor Telschow, nor Verschuer and Lenz - in a sense, the roles had already been distributed in the preliminary talks, and the course and result of the consultations set beforehand. The entire meeting was completed in just $90 \mathrm{~min}$, and the society retired to Harnack House for a snack.

\footnotetext{
${ }^{67}$ This proceeds from the handwritten marginals on this draft by Telschow, dated to 4/12/1940. MPG Archive, Dept. I, Rep. 1 A, No. 2400, p. 159.

${ }^{68}$ File note by Telschow about a meeting with Fischer, 18/10/1940, MPG Archive, Dept. I, Rep. 1 A, No. 2409, p. 81.

${ }^{69}$ Niederschrift über die Sitzung des Kuratoriums des KWI-A am 9.1.1941, MPG Archive, Dept. I, Rep. 1 A, No. 2400, pp. 186 and 195, quotes: p. 195.
} 


\subsubsection{The Conversion Takes Shape}

On the very day after the board meeting, Conti turned to Telschow to coordinate the next steps. The General Secretary of the KWG drew up two letters in the name of the Reichgesundheitsführer, which he forwarded for Conti's signature. ${ }^{70}$ One was directed to Rudolf Mentzel, the president of the German Research Association. It contained a request to the DFG to approve Fischer's application for a research grant of 40,000 RM for the 1941/42 fiscal year to finance the Department for Experimental Genetic Pathology ${ }^{71}$ - the sum had increased over Fischer's original estimate, as Fischer now wanted to hire a clinical physician for the department as well. To the KWG Fischer justified this decision with the Board of Trustee's express wish "to bring the experimental [...] results in as rapid and lively connection with the humanclinical questions as possible." "From the close cooperation between the zoologist and theoretical genetic researcher Nachtsheim and a clinical physician [he hoped for] an acceleration of the results and and adaptation of the formulated questions to the burning questions of medicine." ${ }^{72}$ Fischer submitted the application heralded by Conti to the German Research Association on March 13, 1941, and the grant was issued by the Reich Research Council on March 26 without further ado. "The influence of Conti," Lösch established correctly, "was worth its weight in gold [...]."74

But Conti's patronage did more than make the money sources gush forth: The second letter Telschow prepared for Conti in January 1941 was directed to the responsible District Economic Office (Bezirkswirtschaftsamt) and applied that the KWI-A be recognized as strategically important for the war because of the research to be performed at the new Department for Experimental Genetic Pathology in the course of formation. Since the beginning of the war it had been a formidable obstacle to the work of the institute that it was the only one of the total of 14 Kaiser Wilhelm Institutes (including the General Administration of the KWG) in the region of the Mark Brandenburg province not to be classified as a "W" concern (for Wehrwirtschaft, army economy).$^{75}$ Here, too, Conti sought to remedy the problem,

\footnotetext{
${ }^{70}$ Telschow to Conti, 24/1/1941, MPG Archive, Dept. I, Rep. 1 A, No. 2399, pp. 199-200. In this Telschow complied with a request by Conti. Conti to Telschow, 10/1/1941, MPG Archive, Dept. I, Rep. 1 A, No. 2413, p. 64.

${ }^{71}$ Conti to Mentzel (draft), 23/1/1941, MPG Archive, Dept. I, Rep. 1 A, No. 2399, p. 201. The letter was actually sent in this form. Cf. Fischer to Deutsche Forschungsgemeinschaft, 13/3/1941, BArch. Koblenz, R 73/11.004.

${ }^{72}$ Fischer to KWG, 21/1/1941, MPG Archive, Dept. I, Rep. 1 A, No. 2413, pp. 65-65 v, Quotes: p. 65 v. On the very same day, 20/1/1941 Fischer had submitted the calculation without the clinical physician. Fischer to KWG (with handwritten supplement), 20/1/1941, MPG Archive, Dept. I, Rep. 1 A, No. 2409, pp. 90a-90a v.

${ }^{73}$ Fischer to DFG, 13/3/1941; Reichsforschungsrat to Fischer, 26/3/1941, BArch. Koblenz, R 73/11.004.

${ }^{74}$ Lösch, Rasse, p. 375.

${ }^{75}$ Conti to Bezirkswirtschaftsamt für den Wehrwirtschaftsbezirk III (draft), n.d., MPG Archive, Dept. I, Rep. 1 A, No. 2399, pp. 203-204.
} 
just as he also supported Telschow's request for the classifying the pathologist Otto Baader as "indispensable" with the responsible Military District Command (Wehrkreiskommando) after such an application by Fischer had been rejected. ${ }^{76}$

Conti supported the undertaking as best he could, even after Fischer had finally secured the appointment of Abel as his successor to the professorship for anthropology, and Verschuer as his successor for the directorship of the institute in winter 1941/42. Verschuer came to Berlin on May 5, 1942 and put his ideas and demands on record. In the case of his appointment, he guaranteed, he would continue the research under the banner of phenogenetics according to the wishes of Eugen Fischer, but in doing so would stick to his own research profile, shifting the emphasis to genetic pathology. Further, he and his pupils would continue the twin and family studies already begun. Accordingly, a small polyclinical and a small clinical department were to be created at the institute, which was to employ two national social workers (Volkspflegerinnen) and two nurses. His own Department for Human Genetics, for which Verschuer requested two further assistant positions, would continue to work closely with the Department for Experimental Genetic Pathology. "As a central, connecting node between these, a new Department for Embryology should be set up." The planned changes, so Verschuer calculated, necessitated an increase of 38,000 RM in the personnel budget and 23,000 in the material budget. Besides this, Verschuer's plan earmarked non-recurring expenditures - for a new stall building for Nachtsheim's rabbit breeding, a laboratory for the animal breeding, equipment of the clinical and polyclinical departments, etc. totaling 106,000 RM. Verschuer also requested, if possible, a full professorship at the Medical Faculty of the University of Berlin. ${ }^{77}$ Despite the strained financial situation, the KWG accepted Verschuer's ambitious plans surprisingly readily - after Verschuer had conducted a conversation with the president of the KWG on May 8, 1942, the fulfillment of his demands was approved, initially orally; and this approval - upon his express wish - was confirmed in writing shortly thereafter. ${ }^{78}$ There is no indication that the KWG, and be it "even only pro forma," had been on the lookout for another candidate for the post of director. Correctly, Lösch assesses: "Fischer had been successful with his tactics of making Verschuer out to be the only sufficiently qualified candidate." 79

In July 1942 Fischer received the message that his son Hermann had been killed in action on the Eastern Front - he lost any interest in the work of the institute and

\footnotetext{
${ }^{76}$ Telschow to Conti, 24/1/1941, MPG Archive, Dept. I, Rep. 1 A, No. 2400, pp. 199-200.

${ }^{77}$ Niederschrift vom 5.5.1942, ibid., pp. 225-227.

${ }^{78}$ Verschuer to Telschow, 10/6/1942, MPG Archive, Dept. I, Rep. 1 A, No. 2409, p. 125; Telschow to Verschuer, 13/7/1942 (transcript of excerpts), ibid., pp. 126-126 v. The request for a written confirmation, Telschow wrote, seemed to him "indeed somewhat unusual, since you know the Kaiser Wilhelm Society and therefore also know that oral approvals from the direction of the society are always observed and viewed as binding." The budget increase would presumably "not come into question until after the end of the war [...], because you could not use the increased budget now due to a lack of personnel." (ibid.).

${ }^{79}$ Lösch, Rasse, p. 390.
} 
moved to Freiburg in August. Due to an illness he was not able to resume the business of the institute. Since Verschuer was not able to take over direction of the institute until October 1, 1942, in September - irony of fate - Fritz Lenz was appointed interim director.

On October 28, 1942 Verschuer continued his negotiations with the KWG. During these negotiations he appeared full of self-confidence and demanded that the grants from the Reich and the Prussian state be increased considerably in the next fiscal year. ${ }^{80}$ Yet finances were not the decisive problem - although the increase in public grants demanded by Verschuer was rejected, he ultimately received the money from the DFG and from the "Sponsorship Association of German Industry" (Förderergemeinschaft der deutschen Industrie). More difficult to master, as the negotiations on October 28, 1942 evince, were the restrictions on facilities and personnel due to the war. Here, too, Verschuer pinned his hopes on Conti. With the assistance of the Reichgesundheitsführer, the new director hoped to win back the lower rooms of the institute, which had been used as sanitary facilities up to that time. Further, Conti was to procure the construction permit for extending the attic - until then the skull collection had been kept there, which now was to be transferred to the university - into a sickroom and rooms for the nurses. Further, Verschuer hoped to achieve with Conti's help that Gottschaldt and his colleague from Frankfurt Hans Grebe (1913-1999) be classified as "indispensable." 1 Originally Conti was to be addressed in a board meeting, but since this never took place, Verschuer and Walter Forstmann (1900-1956) from the General Administration visited Conti at his office on November 24, 1942. The Reichgesundheitsführer willingly pledged his support on all points, inquired as to the works in progress and promised to tour the institute over the course of the next 6 months.

\subsubsection{Conti's Interests: Tuberculosis Research and Population Policy in the East}

Whence the interest of the Reichgesundheitsführer? Why did he regard the research which the newly oriented institute intended to take on as a resource for his political ambitions? In any case the tuberculosis research performed by Diehl and Verschuer was highly interesting for the Reichgesundheitsführer. In late 1939 Conti still struck a positive balance: tuberculosis may have increased, but only because of improved diagnostics; the tuberculosis mortality, by contrast, had diminished. ${ }^{82}$ In a lecture not intended for the public - about the "Health Balance in the Second Year of the

\footnotetext{
${ }^{80}$ File note by Telschow about a meeting with Verschuer on 28/10/1942 (transcript of excerpts). MPG Archive, Dept. I, Rep. 1 A, No. 2409, p. 136.

${ }^{81}$ File note by Telschow about a meeting with Verschuer on 28/10/1942, MPG Archive, Dept. I, Rep. 1 A, No. 2400, pp. 239-239 v.

${ }^{82}$ Typed manuscript, based on the stenographic transcript of a lecture held by Conti in late 1939 in Münster. Estate of Leonardo Conti, private collection.
} 
War," which Conti held at the Humboldt Club in Berlin on August 7, 1941 for the editors of German journals, he expressly designated tuberculosis as

[L]east advantageous point [...]. Tuberculosis increased, especially in the areas with endangered air like Hamburg and Kiel. [... I I presumably do not need to indicate especially that we have not yet been able to implement a major social program. We have had no time for this since 1933. Before 1933 the German Volk was standing at the brink. Then came the political revolution. Many retrenchments had to be undertaken for the fortification of the German Volk. ${ }^{83}$

Under these circumstances the genetic research of tuberculosis had to be of immense interest for the Reichgesundheitsführer, especially as it can certainly be presumed that Fischer played this card in the decisive conversation with Conti. Back at the beginning of World War II he had justified his application to the General Administration for feed for the 200 rabbits in Beetz by claiming that there was "no doubt that these studies from the area of one of the worst national epidemics promise to be of great importance for fighting human tuberculosis" $" 84$ - a justification that was forwarded by the General Administration to the responsible Food Office (Ernährungsamt) almost word for word. ${ }^{85}$

That Conti was familiar with Diehl's and Verschuer's tuberculosis research can be proved on the basis of an (undated) typed lecture manuscript on the subject of "Genes and Performance" (Erbgut und Leistungsfähigkeit):

The genetic disposition also plays a role in infectious diseases. The views about heritability have oscillated extremely. First it was observed that tuberculosis occurred in certain families, then the pathogen was discovered and the way it befalls the diseased, namely in earliest childhood; the disease is then carried forth and does not break out until puberty and professional life and even later: at that point no one considered that the disease in question might have been acquired in childhood. It was twin research that illuminated us to the fact that this congenital inferiority is important in tuberculosis. It was possible to establish that identical twins who grew up separately nevertheless got tuberculosis. If a person is resistant he will not become ill if he is only susceptible. It is clear that someone who may be absolutely resistant, but becomes a tuberculosis doctor or nurse, ultimately does take in the bacillum, which then spreads in the body. A doctor who may come from a tuberculous family, but so far has remained entirely healthy, may not become a tuberculosis doctor, for the risk of infection is too great. In other respects the environmental influences are important in fighting tuberculosis; reasonable living conditions must be created. ${ }^{86}$

\footnotetext{
${ }^{83}$ Lecture by Reichgesundheitsführer State Councilor Dr. Conti, "Die Gesundheitsbilanz im zweiten Kriegsjahr," held on August 7, 1941, in the Humboldtclub Berlin for editors of the journal press, typed manuscript, pp. 15-16. Estate of Leonardo Conti. In the discussion Conti responded to an inquiry from the audience: "The possibilities of accommodating those who have just fallen ill are exhausted. It is a great effort for me to create new tuberculosis sanctuaries. All of the homes and sanatoriums I have today have been taken for resettlement. The SS, police and HJ and other institutions require rooms for their purposes. A vast lack of tuberculosis beds exists. I turned to the head of the district to request that beds be made available to us. The serial tuberculosis study can no longer be expanded, and because it also can no longer examine all suspects. Thus the series study must mark time. For the future it will be carried out without a doubt." Ibid., pp. 17-18.

${ }^{84}$ Fischer to Telschow, 8/9/1939, MPG Archive, Dept. I, Rep. 1 A, No. 2399, p. 136.

${ }^{85}$ Telschow to Ernährungsamt Berlin-Zehlendorf, 14/9/1939, ibid., p. 136 a.

86 "Vortrag: Erbgut und Leistungsfähigkeit," estate of Leonardo Conti.
} 
If any further proof is needed that tuberculosis research was irresistible bait for the Reichgesundheitsführer, it is provided by a letter which Verschuer wrote on January 27,1941 - that is, just 3 weeks after the decisive board meeting - to his friend Karl Diehl. The latter had asked for advice about whether he should set about expanding the rabbit hutches in Sommerfeld. Verschuer's advice ran as follows:

I would undertake absolutely everything that is at all possible. So build with all of the money and material you get! Since your research activity was acknowledged at the Board Meeting of the institute in Dahlem by the relevant people, above all by the City Medical Councilor and Reichgesundheitsführer, and its continuation declared to be urgently necessary, you need not have any concern about your future. Your tendency toward moving forward is thus altogether correct. ${ }^{87}$

In the end, Verschuer's assessment turned out to be right. Diehl's project enjoyed high priority up to the end of the Third Reich. Upon Verschuer's application, the Reich Research Council classified Diehl's research on tuberculosis as "important for war and state" and issued a corresponding research contract on August 18, 1943. Achim Trunk is correct to emphasize that Diehl's project was the only one of all of the research projects being conducted at the KWI-A in 1944 to be granted the higher priority of "SS." ${ }^{8}$ Since the costs of the project ultimately consumed a large portion of the institute budget, in February 1944 Verschuer submitted an application for funding of 10,000 RM to the Reich Research Council, which was also approved without a hitch. "It is truly unpleasant for me to be the greatest consumer of the institute's funds," Diehl commented about the application. "Couldn't money be saved? But where? Everything I have is still so meager and yet so much money. It embarrasses me. And if anything is to come of it, this is only the beginning." 90

Conti's interest in tuberculosis research is easy to understand. But here the thesis will be advanced that Conti was interested by no means only in genetic pathology research, but also in research under the banner of phenogenetics. This thesis is supported by a source from the estate of Leonardo Conti, which indicates that, at the time when the negotiations about the reorganization of the KWI-A were under way, the Reichgesundheitsführer was fervently interested in issues of "ethnic cleansing" in occupied Poland, the "Germanization" of Poland and the resettlement of German nationals. Conti was concerned with this complex of subjects because of the danger of epidemics associated with the resettlement of German nationals. At Himmler's request, in December 1939 the RuSHA had presented the draft of a "Selection System for the Settlement of the New Reich Districts" (Ausleseordnung für die Besiedlung der neuen Reichsgaue), which also entailed the participation of the Reichsgesundheitsführer. ${ }^{91}$ In this context Conti,

\footnotetext{
${ }^{87}$ Verschuer to Diehl, 27/1/1941, MPG Archive, Dept. III, Rep. 86 A (Münster), No. 7.

${ }^{88}$ Trunk, Zweihundert Blutproben, pp. $44 \mathrm{f}$.

${ }^{89}$ Verschuer to Diehl, 25/2/1944, MPG Archive, Dept. III, Rep. 86 A (Münster), No. 7.

${ }^{90}$ Diehl to Verschuer, 29/2/1944, MPG Archive, Dept. III, Rep. 86 A, No. 32.

${ }^{91}$ Heinemann, "Rasse," pp. $233 \mathrm{f}$.
} 
accompanied by the internist Heinz Kalk (1895-1973) $)^{92}$ flew to Przemysl on January 13, 1940, in order to personally witness the arrival of a trek of German nationals from Volhynia in the Ukraine. ${ }^{93}$ On February 29, 1940 Conti held a lecture for the SS Reichsführer to convey the impressions from his trip and to present his proposals for "ethnic cleansing." A handwritten sheet upon which Conti noted talking points for this meeting provides information about the Reichgesundheitsführer's ideas for the new population order:

East Prussia - Silesia - Danzig- W[est Prussia] - Warthegau[:] 26 million people, half of them German, 71/2 million Poles, 1/2 million Jews. Government: 14 million [,] of whom 21/2 million Jews. Problem must stop. Different types.

Nordic type who profess to be Polish, does not submit [.] Pure Huns, all variants of cross-breeds, made nations through our blood. Führer even solicited, for no order possible otherwise. First separation, then interbreeding, colonists fetched later. Power of the Reich diminishing, increasing. Ebb and flow, at times colonists fetched again. Language is accepted. [...] The Germans by blood then became the best Polish soldiers, always the bravest opponents. Endangers only our own blood. Let nothing more flow away, get it all back. Rigor in the goal, adaptability in the method. Elimination of leading personalities required.

Race and nationality mixed up [?]

Congress Poles in part better racially than Poles from Poznan, and Silesia Poles in part better than German nationals.

Volhynia and Galicia 135,000 (110,000 peasant families[,] rest tradesmen) Nat. Russia around 20,000[.] Southern Tyrol 230,000.

Germans elsewhere in the world is a question which may not be touched on. Likewise 40,000 Germans in Lithuania.

General government: Training [residential?] area: Polish self-administration required. 40,000 German nationals must be returned from Lublin and Chelm.

Polish workers marked. Strict segregation. Business, shopping for Poles only on certain day. Polish workers hanged for Rassen[schande?] ("race disgrace" - interracial intercourse). Polish women available for the Poles. German women to concentration camp.

Baltics: take luggage, all want to go to Poznan.

Volhynia Germans: fabulous. Believe in the Führer. Surrendered gold and food. Bought horses and brought with them. Wanted to surrender wedding rings.

Now there is no purchase of land, no application for settlement, etc. Those who have moved in may not have the feeling of discrimination and must not be discriminated against.

Improve climate in the East by planting.

Settle border zone and build bridges. Split up settlements as they were split up militarily.

Settle mixture of Volhynia Germans, German nationals and Reich Germans in village.

Inbreeding of German nationals ceases. Political fertilization.

Führer after the war: Off to the East.

Merge estates in the former Reich fragmented by distribution among heirs.

Racially and politically good people to the East. ${ }^{94}$

\footnotetext{
${ }^{92}$ For a biography: Klee, Personenlexikon, p. 296.

${ }^{93}$ On this the estate of Leonardo Conti includes a photo album compiled by Heinz Kalk, who accompanied Conti on this flight.

${ }^{94}$ Note by Conti, "Himmler, 29/2/1940," estate of Leonardo Conti (original emphases).
} 
In reality, Conti's influence on "Germanization policy" in the occupied areas remained marginal ${ }^{95}$ - but that could not be foreseen in 1940 . One can certainly presume that Fischer, in their conversation on November 12, 1940, drew the Reichgesundheitsführer's attention to the fact that Fritz Lenz had turned to the "burning issues of resettlement and race hygienic population policy" in 1939/40. Similarly, Fischer must have referred Conti to the KWI-A scientists' activity preparing evaluations for the Reich Genealogical Office. In his meeting with Conti Fischer probably also addressed the research on embryonic animal and human skulls carried out at the institute, which had the objective of determining race differences by means of embryological methods. Presumably he also mentioned the studies in progress on race dermatoglyphics, which were based on the serial anthropological studies Fischer had initiated in the Łódž ghetto. Finally, it cannot be excluded that Fischer presented in his talk with Conti considerations on a serological race diagnostics, like the one developed in connection with Engelhardt Bühler's project on the heritability of agglutinines in 1935. In any case, placing the KWI-A under his protection appeared to offer the Reichgesundheitsführer the chance to secure the political monopoly on potentially groundbreaking methods of race diagnostics, which would be far superior to the anthropometric methods applied in occupied Poland.

\subsection{Internal Structures}

\subsubsection{Finances}

The reorganization under the banner of phenogenetics had significant consequences for the institute budget. The size of the budget grew continuously in the war years. The sum of revenues and expenditures shown in the yearly accounts in the 1943/44 fiscal year was 208,000 RM, clearly higher than the 144,000 RM in the 1940/41 fiscal year - compared to the 1933/34 fiscal year, when the revenues and expenditures

\footnotetext{
${ }^{95}$ In the subsequent period Conti rarely succeeded in getting through to Himmler. His suggestion to resettle entire villages of German nationals from Bessarabia as communities was the subject of consultations between Himmler and SS Gruppenführer Ulrich Greifelt (1896-1949), the chief of the Office of the Reich Commissioner for the Consolidation of German Nationhood (Dienststelle des Reichskommissars für die Festigung deutschen Volkstums) in May 1942. Conti himself was no longer consulted. Cf. Witte et al., Dienstkalender Heinrich Himmlers, p. 432, note 66.

${ }^{96}$ Fischer, Tätigkeitsbericht 1939/1940, MPG Archive, Dept. I, Rep. 3, No. 17. In his activity report for 1940/41 Fischer wrote that Lenz had written several exposés on "The Population Policy of the Peasantry," on "Resettlement" and on "The Methodology of Race Research," the first two of which were not intended for publication. In the draft of the report he wrote: "Mentioned in particular are certain works by Mr. Lenz that are not intended for publication, on issues of resettlement and the assessment of demographic and population policy works and issues." Fischer, Tätigkeitsbericht 1940/1941 (draft, clean copy, resp.), MPG Archive, Dept. I, Rep. 3, No. 18.
} 
amounted to $104,700 \mathrm{RM}$, the total balance had nearly doubled. On the expenditure side, the personnel costs exploded as a result of the new hirings over the course of setting up new departments or reorganizing old ones. They climbed from around 76,500 RM (1940/41) to 131,500 RM (1942/43), while the material costs, aside from a temporary rise through new acquisitions in the 1942/43 fiscal year, persisted at around 50,000 RM. On the revenue side, the latitude for an increase in the grants from the Reich and Prussia was limited. This had not yet been a problem in the Fischer era, since the institute had significant reserves at its disposal, with which the rising costs could be defrayed initially. In the Verschuer era, by contrast, this financial padding dwindled rapidly, as the running expenditures peaked their pinnacle. Since the inflexible personnel costs made up the lion's share, savings measures were practically impossible without reducing personnel. From the 1942/43 fiscal year on, the institute lived beyond its means. In order to be able to continue working in the same order of magnitude as it had until then, it was dependent on the constant flow of third-party funds of considerable scope. This, in turn, had effects on the research program and practice.

The initial financial situation when Fischer set about to reorganize his institute was not as bad as he had portrayed it to the Board of Trustees. It had been possible to stop the gap left by the cuts at the start of World War II through the significant surpluses amassed in the years from 1933 to 1939. In September 1939 the subsidies from the Reich and Prussia planned for 1939/40 were cut to 150,500 RM, despite Fischer's vehement protest ${ }^{97}$ - the shortfall of nearly 10,000 RM resulting from this cut ate up around half of the credit balance from the previous years. ${ }^{98}$ In the 1940/41 fiscal year the subsidies from the Reich and from Prussia were cut by another 10,000 RM to 140,500 RM, but the expenditures dropped so sharply due to the drafting of nearly all scientific staff and "the cessation of research works associated therewith" 99 that a surplus of nearly 17,000 RM remained at the close of the fiscal year. This, together with the remaining surpluses from the previous years, yielded a credit balance of almost 27,000 RM, which was transferred to the new budget in view of the research projects the institute had been forced to defer because of the war. Added to this was a travel fund of 10,000 RM, leaving the

\footnotetext{
${ }^{97}$ Cf. Fischer to Generalverwaltung, 23/9/1939, MPG Archive, Dept. I, Rep. 1 A, No. 2409, pp. 52-52 v: "A certain reduction as a result of the war situation is certainly understandable. But the overall situation is not such that the institute will be closed. [...] All of our operations, which, of course, were greatly restricted in the past, first weeks of the war, are coming back into gear. It would be entirely wrong to perform exclusively chemical and physical science because these can be put directly in the service of military economy. Our studies about hereditary diseases are at least as important for the Volk." Thus Fischer rejected - successfully - huge cuts to his budget.

${ }^{98}$ Schröder, Bericht über die Prüfung des Rechnungsabschlusses zum 31/3/1940, 5/9/1940, ibid., pp. 74-76; Vermögensübersicht zum 31/3/1940, ibid., p. 77; Einnahmen- und Ausgabenrechnung für das Rechnungsjahr 1939, ibid., p. 78.

${ }^{99}$ Schröder, Bericht über die Prüfung des Rechnungsabschlusses zum 31/3/1941, 28/4/1941, ibid., pp. 99-101, quote: p. 99; Vermögensübersicht zum 31/3/1941, ibid., p. 102; Einnahmen- und Ausgabenrechnung für das Rechnungsjahr 1940, ibid., p. 103.
} 
KWI-A with "secret reserves" of around 37,000 RM in April 1941. In other words: The balances could barely conceal that Fischer was again hoarding money in his institute for future research projects.

In comparison to the balances for the 1940/41 and 1941/42 fiscal years, however, it becomes apparent that funds flowed even faster now. The subsidies from the Reich and Prussia increased by about 16,500 RM. They reached the level of $157,000 \mathrm{RM}$ and thus more or less that of the late 1930s. Despite the dramatically increased personnel costs - a consequence of founding the Department for Experimental Genetic Pathology - at the end of the fiscal year a new surplus of over 5,000 RM remained, so that the surpluses, including the full-to-bursting travel fund, totaled over 42,000 RM - and this although of the 40,000 RM earmarked for Nachtsheim's department from the German Research Association, only 22,000 RM were called in right away. And because this subsidy could not be spent in any reasonable way, with the consent of the General Administration it was used for the purchase of the library and collection of specimens from the private property of the departing director - the money thus flowed into Fischer's pockets. The rest could be transferred to the next accounting year. ${ }^{100}$ In other words: At the start of the 1942 budget year the institute had "silent reserves" of 70,000 RM at its disposal, more than a third of the entire KWI-A budget.

Not until the 1942/43 fiscal year did the unchecked expansion thrust result in a hefty deficit. The subsidies from the Reich and Prussia diminished to 140,000 RM, and although the oustanding payment of 18,000 RM from the DFG balanced this out, the revenues were not sufficient to cover the dramatically increased expenditures. The personnel costs were the largest post - in this fiscal year alone, three new scientific assistants and eight technical and administrative employees were hired. The deficit ultimately amounted to 29,000 RM, through which the accumulated reserves dwindled to just under 3,000 RM; however, this did not include the travel fund of over 10,000 RM, which remained untouched. ${ }^{101}$

The new director Otmar von Verschuer was faced with a weighty problem. The personnel costs had exploded so greatly as a consequence of creating the Departments for Human Genetics and Experimental Genetic Pathology that they far surpassed the level of the usual grants. In the negotiations with the General Administration about his appointment on October 28, 1942 Verschuer thus submitted a cost estimate of 234,000 RM for the 1943/44 fiscal year. In oral negotiations Telschow made clear that, while an increase had been requested from the Reich Education Ministry, it could not be expected in such an order of magnitude. ${ }^{102}$ This assessment was to prove correct: The allocations from the Reich and the Prussian state did

\footnotetext{
${ }^{100}$ Schröder, Bericht über die Prüfung des Rechnungsabschlusses des KWI-A zum 31/3/1942, 27/7/1942, ibid., pp. 127-129; Vermögensübersicht zum 31/3/1942, ibid., p. 130; Einnahmen- und Ausgabenrechnung für das Rechnungsjahr 1941, ibid., p. 131.

${ }^{101}$ Schröder, Bericht über die Prüfung des Rechnungsabschlusses des KWI-A zum 31/3/1943, 27/4/1943, ibid., p. 146 f.; Vermögensübersicht zum 31/3/1943, ibid., p. 148; Einnahmen- und Ausgabenrechnung für das Rechnungsjahr 1942, ibid., p. 149.

${ }^{102}$ File note by Telschow, 28/10/1942 together with the cost estimate for 1943/44, ibid., p. $135 \mathrm{f}$.
} 
increase back to $156,000 \mathrm{RM}$ in the $1943 / 44$ fiscal year, however, under the condition that the remaining funding gap of 77,000 RM be covered by another source. In this situation, Alfred Kühn, deputy director of the KWI for Biology, who had followed the reorganization of the KWI-A around phenogenetics since 1938 with interest, leapt into the breach. In his capacity as Chairman of the Biology and Medicine Section of the Academic Council of the KWG, he took part in the meeting of the KWI-A Board of Trustees on May 4, 1943, which was dominated by the financial crisis. Kühn suggested turning to the Association of Sponsors of German Science (Stifterverband der Deutschen Wissenschaft), which had free funds at its disposal at the time. To this effect Friedrich Schmidt-Ott, the Chairman of the Association of Sponsors, was to be addressed, who also belonged to the Board of Trustees, but had not attended the meeting on May 7. Also missing was Reichsgesundheitsführer Leonardo Conti, who had supported all of the institute's financial requests so effectively before. Conti's star was waning by this time, and it is striking that Fischer, Verschuer, Telschow, and Kühn, who were alone at the meeting on May 7, 1943, no longer included Conti in their calculations, but rather decided to arouse the interest of Conti's former rival, Karl Brandt (1904-1948), ${ }^{103}$ who had since overtaken Conti in importance as the "accompanying physician" of the Führer, one of the two figures responsible for the "euthanasia" program, and since July 1942 also Hitler's authorized representative for the Medical and Health Service, in the institute's work. ${ }^{104}$

Telschow took immediate action. Just 1 day after the board meeting, on May 8, 1943, he addressed Schmidt-Ott - with express reference to Kühn. ${ }^{105}$ Since the Association of Sponsors no longer had such a high sum at its disposal, Schmidt-Ott forwarded the letter from Telschow to Albert Vögler, president of the KWG since 1941, who suggested directing a petition to the "Sponsorship Association of German Industry" (Förder[er]gemeinschaft der deutschen Industrie), to request a nonrecurring grant of 100,000 RM. ${ }^{106}$ Verschuer kept this possibility under his hat for the moment. For in the meantime, on May 24, 1943, the German Research Association - in response to an application by Verschuer on March 23, 1943 - had approved 40,000 RM for the institute in Dahlem, for "studies in the area of comparative genetic pathology." 107 In June 1943 Verschuer reported that Kühn was

\footnotetext{
${ }^{103}$ Süß, Aufstieg; idem., "Volkskörper"; Klee, Personenlexikon, pp. $70 \mathrm{f}$.

${ }^{104}$ Niederschrift über die Sitzung des Kuratoriums des KWI-A am 7/5/1943, MPG Archive, Dept. I, Rep. 1 A, No. 2404, p. 68 f.

${ }^{105}$ Telschow to Schmidt-Ott, 8/5/1943, MPG Archive, Dept. I, Rep. 1 A, No. 2409, pp. 152-152 v: "Prof. Kühn is well disposed to instruct Your Excellency personally about the areas of work currently being worked on at the institute, especially about those we have just begun to study."

${ }^{106}$ Vögler to Telschow, 21/5/1943, ibid., p. 158. Schmidt-Ott belonged to the Administrative Council, Vögler to the Board of Trustees of the Sponsorship Association. Cf. Schulze, Stifterverband, pp. $91 \mathrm{f}$.

${ }^{107}$ Verschuer to Präsident des Reichsforschungsrates, 23/3/1943, BArch. Koblenz, R 73/15.342, pp. 97-98; Reichsforschungsrat to Verschuer, 24/5/1943, ibid., p. 96. Verschuer's application had been supported by Reichsgesundheitsführer Conti. Cf. Reichsgesundheitsführung, Verbindungsstelle
} 
negotiating with Schmidt-Ott about the remaining deficit of 37,000 RM. ${ }^{108}$ These negotiations ultimately resulted in resorting to Vögler's offer: on September 7, 1943 the Association of Sponsors of German Industry approved a 3-year research grant of 47,000 RM annually for the KWI-A. ${ }^{109}$

The Association of Sponsors of German Industry had been founded officially in November 1941. The motives that led to the founding of this organization were located on two levels: For one, in view of the profit restrictions imposed upon business by the National Socialist regime, sponsoring research was simply a possibility for "investing the considerable war profits, when the traditional possibilities for reducing profits, that is, increasing share capital and increasing capacity, no longer appeared interesting." Second, leaders in industrial circles were concerned about theoretical research and the sponsorship of young scientists - at a point in time that coincided with the "first disillusionment about Germany's chances of military success" and in view of "the future existence of business and research in a postwar period." Extremely interesting - and until now disregarded - is that the economic leaders assembled in the Association of Sponsors accorded such great importance to phenogenetic research in Dahlem in this context that they approved quite a considerable amount for the KWI-A. By way of comparison: In spring 1943 the Association of Sponsors had an endowment of 22 million RM, of which a total of around 800,000 RM in interest yields were available for distribution. ${ }^{110}$

In the 1943/44 fiscal year, besides the subsidies from the Reich and Prussia, the KWI-A received third-party funds from the Association of Sponsors and the DFG amounting to $87,000 \mathrm{RM}$. In the $1944 / 45$ fiscal year this total even increased, to 97,000 RM, as the DFG not only renewed its grant of 40,000 RM, ${ }^{111}$ but also, as mentioned above, responded to Verschuer's petition by providing an additional 10,000 RM for Diehl's tuberculosis research. ${ }^{112}$ In August 1944 Verschuer was able to state with satisfaction, in a letter to his friend Bernhard de Rudder:

\begin{abstract}
Surprisingly, the cutbacks I expected in my institute have not come to pass; on the contrary, great value is placed on continuing the research important to the war. And so the cogs remaining in my institute machine are turning at full speed, as if the entire machine were still running. But I am glad that so much remains in operation, and that thus still quite a bit of productive work can be performed. ${ }^{113}$
\end{abstract}

Berlin, to Geschäftsführender Beirat des Reichsforschungsrates, 24/5/1943, ibid., p. 95; Geschäftsführender Beirat des Reichsforschungsrates to Reichsgesundheitsführung, Verbindungsstelle Berlin, 2/6/1943, ibid., p. 94.

${ }^{108}$ Note for the file by Reinold, 8/6/1943, MPG Archive, Dept. I, Rep. 1 A, No. 2409, p. 158.

${ }^{109}$ Arndt to Deutsche Industriebank, 10/2/1944, ibid., p. 169.

${ }^{110}$ Schulze, Stifterverband, pp. 89-94, quotes: p. 90.

${ }^{111}$ Verschuer to Präsident des Reichsforschungsrates, 20/3/1944, BArch. Koblenz, R 73/15.342, pp. 78-78 v; Reichsforschungsrat to Verschuer, 16/5/1944, ibid., p. 77.

${ }^{112}$ Verschuer to Präsident des Reichsforschungsrates, 25/2/1944, ibid., pp. 92-92 v; Reichsforschungsrat to Verschuer, 6/4/1944, ibid., p. 91.

${ }^{113}$ Verschuer to de Rudder, 31/8/1944, MPG Archive, Dept. III, Rep. 86 A (Münster), No. 8. 
Since the subsidies from the Reich and Prussia had been fixed at 156,000 RM, the ratio of public subsidies to third-party funds was 3:2 in the final budget year. ${ }^{114}$ In other words: The subsidies from the German Research Association and the Association of Sponsors of German Industry were of vital importance for the institute from 1943 on.

\subsubsection{Hans Nachtsheim, Director of the Department for Experimental Genetic Pathology}

The new Department for Experimental Genetic Pathology was tailored precisely to the zoologist Hans Nachtsheim. He studied zoology in Bonn and medicine in Munich from 1909 to $1912 .{ }^{115}$ In 1913 he received his Ph.D. under Richard Goldschmidt at the University of Munich, where he became an intern at the Zoological Institute. In 1914 he moved to the Zoological Institute at the University of Freiburg under Erwin Baur, where he also met Eugen Fischer. In 1915 he was drafted into military service, where he spent most of his duty working as a censor at the military surveillance posts in Karlsruhe, Freiburg, and Munich. In summer 1919 he was a member of the Epp Freikorps. After working as an assistant to the zoologist Richard Hertwig (1850-1937) at the University of Munich from 1916 to 1921 and receiving his qualification as a professor there, in 1921 he joined Erwin Baur at the Institute for Genetic Research at the Agricultural Academy of Berlin in Dahlem, as Director of the Zoological Department. Nachtsheim spent the years 1926/27 as a Rockefeller Foundation scholar in the United States, where his experiences included sitting in at the laboratory of the drosophila geneticist Thomas Hunt Morgan at Columbia University in New York. Increasingly, Nachtsheim turned to the genetics of domesticated animals and began systematically breeding strains of rabbits with pathological attributes.

At the Congress of the German Society for Genetics in 1937, which took place at Verschuer's Institute for Genetic Biology and Race Hygiene in Frankfurt, Nachtsheim introduced his breeding experiments to the genetic community, and also aroused the attention of those geneticists working on the genetic pathology of humans. After the war, Fischer admitted that the idea of winning Nachtsheim for his institute occurred to him at this congress.

When Fischer approached Nachtsheim in September $1940,{ }^{116}$ the latter did not hesitate. In the very next month he gave notice that he would be leaving his senior

\footnotetext{
114 “Zusammenstellung über Einnahmen und Ausgaben 1937-1946” (MPG Archive, Dept. I, Rep. 1 A, No. 3025) lists the current private revenues of the institute: 42,430 RM (1941/42), 52,100 RM (1942/43), 82,000 RM (1943/44), 99,000 RM (1944/45), 13,700 RM (1945/46, actual amount) and 661 RM (1946/47, actual amount). This compilation does not reveal how the revenue post is put together. ${ }^{115}$ For a biography: Schwerin, Experimentalisierung, esp. pp. 338-341; Lösch, Rasse, p. 368.

${ }^{116}$ Fischer to Verschuer, 20/9/1940, MPG Archive, Dept. III, Rep. 86 C, No. 1: "Nachtsheim accepted in principle and very happily; next week we negotiate with Telschow."
} 
assistantship. His professional status was precarious. ${ }^{117}$ Since 1935, when the Institute for Genetic Research, along with the Agricultural Academy, had been integrated into the Agricultural Faculty of the Friedrich Wilhelm University, his room for maneuver had been severely restricted. Although Nachtsheim had been appointed associate professor of the university in 1939, there was no prospect of a regular professorship, especially since he was considered suspect in party circles. He never joined the NSDAP. ${ }^{118}$ In 1933 he had been dismissed as chairman of the Reich League of German Rabbit Breeders. For Nachtsheim entirely new possibilities for continuing to advance his research on comparative genetic pathology opened up with the switch to the KWI-A, on a secure material foundation, shielded by the Kaiser Wilhelm Society. The new orientation presented no difficulty for him, since his research on the genetic pathology of mammals had been conceived from the outset as a model for human genetics. In 1940 Nachtsheim then also switched from the agriculture to the mathematical-natural sciences faculty of the University of Berlin - he could not bring himself to decide to switch to the medical faculty.

As in the cases of Kurt Gottschaldt and Karl Diehl, ${ }^{119}$ in Hans Nachtsheim, too, Fischer opted for a scientist whose career seemed to have hit a dead end in the Third Reich - and who was rather distanced from National Socialism. This proved to be a skillful move, for Nachtsheim, too, justified the trust placed in him and built the new Department for Experimental Genetic Pathology into a supporting pillar of the KWI-A in a very short time.

\subsubsection{A Director for the Department of Embryology}

In Fischer's and Verschuer's plans for reorganizing the institute in Dahlem, the triangle of clinical genetic pathology of humans, the animal model and embryology was assigned decisive importance in terms of research strategy. The high value placed on embryology in this concept is often overlooked, because the planned Department for Embryology was never founded due to the war. This was not for Verschuer's lack of trying. In June 1942 - that is, a full three months before he took over as director of the institute in Dahlem - he began asking around in his circle of colleagues in order to find candidates for the position of director of the new "Department for Embryology or Genetic Developmental Physiology" in planning. Since the new department was not only to study animal embryos from Nachtsheim's Department for Experimental Genetic Pathology, but also "to build the bridge [...] to humans" and to work "on human material" as well, Verschuer elaborated to

\footnotetext{
${ }^{117}$ Schwerin, Experimentalisierung, pp. $248 \mathrm{f}$.

${ }^{118} \mathrm{He}$ did become member of the NS Dozentenbund, however. Kröner, Von der Rassenhygiene zur Humangenetik, p. 38 (note 105).

${ }^{119}$ Gottschaldt was not a member of the NSDAP, but had joined the NS League of Teachers in 1933 and left it in 1934. In 1936 he joined the NS Dozentenbund. Diehl did not join the NSDAP until 1937. Kröner, Von der Rassenhygiene zur Humangenetik, p. 38.
} 
inquiries that no zoologist, but only an "embryologist coming from the field of anatomy" scientist who was nevertheless well-versed in embryological methods - postdoctoral qualifications were not required. The survey produced very few indications of any utility. An acute lack of young anatomists was a problem at the time, and most of the few younger scientists in this area had been drafted, so that ultimately only one of the candidate's names seemed at all suitable to Verschuer: the university lecturer Dietrich Starck ( $\left.{ }^{*} 1908\right)$, prosector and senior assistant at the Anatomical Institute of the University of Cologne. Verschuer entered into detailed negotiations with Starck and his superior Franz Stadtmüller, the Director of the Anatomical Institute. Starck indicated that he was interested, but expressed from the very beginning reservations because he was "an anatomist, body and soul," 121 and could find that a move to Dahlem could " "sideline' [his chances as] an anatomist" 122 and end up doing himself out of a chair in anatomy. In early 1943 Verschuer and Starck agreed to put the negotiations about the appointment on ice for the time being. In May 1943, Verschuer invited the still hesitant Starck to hold a lecture at one of the upcoming "biological evenings" 123 in Harnack House. These evenings were presided over by Alfred Kühn - the invitation to Starck underlines an earlier indication by Verschuer that "through the close cooperation with the neighboring Kaiser Wilhelm Institutes, above all with von Wettstein, Kühn and Butenandt, quite special working possibilities are presented" for the new Department for Embryology, especially "in joint colloquia and team projects." 124

As becomes apparent in the correspondence between Verschuer and his friend de Rudder, in summer semester 1943 Starck actually did appear "at a Dahlem biological evening" and held a talk about "The Importance of Developmental Physiology for Comparative Anatomy, Explained on the Example of the Head of Vertebrates," which, according to Verschuer, was "outstanding in form and content." Personally, too, Starck had "made the best impression." Ultimately he rejected the appointment to Dahlem, however, because he did not wish to "endanger his anatomical career." "Despite the high qualification of Mr. Starck," Verschuer continued, he was "not unhappy about the rejection," as he had since believed to have found "another and [...] apparently more suitable candidate for the position of department director." The person in question here was the university lecturer Wouter Frans Hendrik Ströer, prosector at the Anatomical-Embryological Institute of the University of Groningen, who had worked as a guest scholar at the KWI-A for several months in 1943. "Ströer is a Dutchman, but entirely on our side." He was "an outstanding researcher personality" and "decidedly the best man

\footnotetext{
${ }^{120}$ Verschuer to Hermann Bautzmann, 2/7/1942, MPG Archive, Dept. III, Rep. 86 B, No. 36, pp. 8-9, quotes: p. 8.

${ }^{121}$ Starck to Verschuer, 9/12/1942, ibid., p. 41.

${ }^{122}$ Stadtmüller to Verschuer, 20/6/1942, ibid., pp. 24-25, quote: p. 24 (original emphasis).

${ }^{123}$ Verschuer to Starck, 7/5/1943, ibid., pp. 88-49, quote: p. 48.

${ }^{124}$ Verschuer to Stadtmüller, 16/11/1942, ibid., pp. 26-29, quotes: p. 28.
} 
I could think of for my institute." Nevertheless it was open to question whether his move to Dahlem would take place. Ströer himself had "doubtlessly the greatest inclination." However, "by order of the Reich Commissioner for the Netherlands," he was supposed "to take over a professorship at the new Reich University in Groningen." 125 The decision was still open.

Verschuer had informed the Reich Education Ministry of his intention to appoint Ströer to departmental director on July 12, 1943 - mediated by the General Administration of the KWG:

Dr. Ströer is a scientist known for his superior research work in the field of developmental history and genetic pathology [...]. He has been occupied with phenogenetic studies as a guest assistant at my institute for some time [...]. Politically I hold him to be altogether reliable and pro-German - he is a storm-trooper of the Germanic SS in the Netherlands. ${ }^{126}$

In the end Verschuer was not able to get his way. As late as September 1944 he reported to de Rudder that Ströer was "still being held back by the Reich University of Groningen (by now one must write 'former'!) for the time being," but his wife and three small children had been "sent here into my protection, as their lives were threatened directly by their fellow countrymen." "Emergency quarters" had been set up for them at the institute. ${ }^{127}$ In a further letter by Verschuer written a short time later, this time to Fischer, he stated that Ströer was "stationed with the SS in Arnheim" and "certainly took part in the heavy fighting there." 128

\subsubsection{Scientific and Non-scientific Personnel}

The total number of "working scholars" remained - on paper - nearly unchanged during World War II: From 37 (1939/49) it fell slightly to 35 (1940/41) and finally to $33(1941 / 42)$, and then rose again over the course of Verschuer's takeover, to 38 $(1942 / 43)$, then $39(1943 / 44) .{ }^{129}$ Yet this impression of relative stability is misleading,

\footnotetext{
${ }^{125}$ Verschuer to de Rudder, 7/11!1943, MPG Archive, Dept. III, Rep. 86 A (Münster), No. 8. In January 1943 Verschuer had proclaimed to Fischer: "As of 1/4/1943 Ströer is coming to the institute as a guest assistant. Perhaps he will be our future embryologist someday [...]." Verschuer to Fischer, 7/1/1943, MPG Archive, Dept. III, Rep. 86 A (Münster), No. 9.

${ }^{126}$ Verschuer to Reichserziehungsministerium, 12/7/1943, MPG Archive, Dept. I, Rep. 1 A, No. 2400 , p. 249.

${ }^{127}$ Verschuer to de Rudder, 16/9/1944, MPG Archive, Dept. III, Rep. 86 A (Münster), No. 8.

${ }^{128}$ Verschuer to Fischer, 29/9/1944, MPG Archive, Dept. III, Rep. 86 A (Münster), No. 9. In an earlier letter to Eugen Fischer, Verschuer mentioned that Ströer had "integrated himself into the German Wehrmacht." Verschuer to Fischer, 9/9/1944, ibid. - After World War II Ströer lived in the Netherlands, undisturbed. Cf. Verschuer to Fischer, 5/2/1953, MPG Archive, Dept. III, Rep. 86 C, No. 11, p. 4 f.

${ }^{129}$ Calculated according to the statements in the annual reports 1939/40, MPG Archive, Dept. I, Rep. 3, No. 17; 1940/41, MPG Archive, Dept. I, Rep. 3, No. 18; 1941/42, MPG Archive, Dept. I, Rep. 3, No. 19; 1942/43, MPG Archive, Dept. I, Rep. 3, No. 20; 1943/44, MPG Archive, Dept. I, Rep. 3, No. 21.
} 
for the numerous drafts into the Wehrmacht thinned out the scientific personnel extremely. As Fischer's activity report for the 1939/40 fiscal year shows, this began as early as spring 1939:

The activity of the institute was restricted, for even in the first five months of the year covered by this report, which were before the outbreak of the war, all assistants but one had been drafted for military drills, sometimes alternately, sometimes simultaneously. ${ }^{130}$

At the beginning of World War II, in addition to the Department Director Kurt Gottschaldt, all assistants of the KWI-A and the majority of the male doctoral students were drafted. Until late 1942 three assistant positions remained unfilled, and the remaining assistants - Wolfgang Abel, Otto Baader, Heinz Lemser, and Siegfried Tschamler ${ }^{131}$ - were in the Wehrmacht and held contact with the institute only sporadically. Thus, the "central block" was lost, so to speak, which not only had the consequence that all of the assistants' research projects lay idle. The supervision of the foreign guest scholars and the remaining doctoral students suffered as well. The fact that the assistants were drafted also meant that Eugen Fischer and Fritz Lenz had to take on more duties in academic instruction - in winter semester 1941/42, Fischer himself had to hold the practical course in anthropology at his university chair, which he had been able to load off to his assistant Abel until that time. ${ }^{132}$ Demands on Lenz's time were made by academic instruction duties, but primarily through the supervision of a great number of dissertations. Further, due to the loss of their assistants, Fischer and Lenz had to take on an even higher degree of activities in producing expert opinions and evaluations.

The situation remained unchanged in the 1940/41 fiscal year - despite Leonardo Conti's intervention there was no success "in freeing up even a single assistant from military service, through which the scientific activity of the institute is greatly

\footnotetext{
${ }^{130}$ Tätigkeitsbericht 1939/40, MPG Archive, Dept. I, Rep. 3, No. 17. The text here continues: "Through this not only their work, but also that of the doctoral students and guests was impeded severely, especially since those who were not drafted had to be drawn upon more frequently than usual to the extensive activity of producing expert opinions that is such a burden for the institute."

${ }^{131}$ Tschamler fell in action on October 1, 1943. Cf. "Meldung für die Ehrentafel," MPG Archive, Dept. I, Rep. 3, No. 21.

132 "When the semester began here, our personal scientific work practically came to a halt. For all that, I have six hours per week, have to take the subway into town twice, around one hour there and one hour back each trip. These two mornings are completely unavailable. For the major practical course I have to prepare myself first, because I have not held it for ten years now, but then have to prepare it technically as well, blood groups, order in twins, etc." Fischer to Verschuer, 2/7/1941, MPG Archive, Dept. III, Rep. 86 A (Münster), No. 9. On summer semester 1942 is written: "From April to July, increasing activity by his colleague took many claims on Professor Fischer's time, because the younger lecturers of the faculty were unavailable." Tätigkeitsbericht by Verschuer 1942/43, MPG Archive, Dept. I, Rep. 3, No. 20. - Considering that Fischer had gone to Rome for three months as an exchange professor after the decisive board meeting on January 9, 1941, and further that he lost any interest in the institute after the death of his son in July 1942, moved to Freiburg in August 1942, took ill there and never returned to Berlin, it becomes clear that Fischer hardly worked as a scientist in the last 2 years of his tenure as Director of the KWI-A. Cf. Lösch, Rasse, p. 389, 392.
} 
limited," 133 Fischer lamented. In the first draft of his activity report the final clause read as follows: "[...] since even among the doctoral students only one foreigner and two ladies remained, the scientific activity of the institute, aside from Professor Lenz, Professor Gottschaldt and the institute director, was completely extinguished." ${ }^{134}$ Fischer's final activity report as Director of the KWI-A, which referred to the 1941/42 fiscal year, began with the resigned observation:

Through the further duration of army service of all assistants, one departmental director [Abel] and at times a second [Gottschaldt], through the lack of nearly all male doctoral students, the institute has not been able to carry out scientific activities on a larger scale. ${ }^{135}$

Not until the change in institute leadership did the personnel situation improve. Wolfgang Abel, by now director of the Department for Race Science, was finally classified as "indispensable" in October 1942, ${ }^{136}$ as was Kurt Gottschaldt, so that all departmental director positions were filled. In the first round of negotiations with the KWG in May 1942, Verschuer had also, as mentioned above, managed to acquire two further assistantships for his own Department of Human Genetics to be reestablished, which he wanted to occupy with his closest colleagues from Frankfurt. In July 1942 Verschuer reported to the race biologist Wolfgang Lehmann of Strasbourg, a member of the "Dahlem circle": "I will take almost all of my staff from here, first of all [Heinrich] Schade and [Hans] Grebe, later [Josef] Mengele and Fromme [...]." ${ }^{137}$ In November 1942 Verschuer then was able to report to Fischer that starting on December 1 he would have "in addition to my Dr. Grebe from Frankfurt, further a Dr. [Siegfried] Liebau as assistant, whom the SS has commanded to us for training. Thus some operations should be able to get back into gear." 138

From December 1942 two assistants were thus on location in Dahlem again: Hans Grebe and Siegfried Liebau. The physician Hans Grebe had closed ranks with National Socialism at an early date, joining the NS Student League in 1931, the NSDAP and SA in 1933, and the NSDÄB in 1937. He took his Ph.D. under Verschuer with a dissertation about genetical and nongenetical blindness. After that he worked as an assistant at the Horst Wessel Hospital in Berlin, before becoming Verschuer's assistant at the Frankfurt Institute for Genetic Biology and Race Hygiene in 1937. Released from the Wehrmacht after he was seriously wounded, Grebe qualified as a professor under Verschuer in 1942 with a postdoctoral dissertation about chondrodysplasia. He moved to Berlin with his mentor, becoming an assistant at the KWI-A and lecturer at the university. From December 1942 on he was among the most active scientists at the KWI-A, until October 1944, when he was appointed at the age of just 31 to associate professor and Director of the

\footnotetext{
${ }^{133}$ Fischer's Tätigkeitsbericht 1940/41, MPG Archive, Dept. I, Rep. 3, No. 18.

${ }^{134}$ Fischer's Tätigkeitsbericht 1940/41 (draft), ibid. This passage was deleted from the final version.

${ }^{135}$ Tätigkeitsbericht 1941/42, MPG Archive, Dept. I, Rep. 3, No. 19.

${ }^{136}$ Verschuer to Fischer, 22/10/1942, MPG Archive, Dept. III, Rep. 86 A (Münster), No. 9.

${ }^{137}$ Verschuer to Lehmann, 11/6/1942, MPG Archive, Dept. III, Rep. 86 A (Münster), No. 5.

${ }^{138}$ Verschuer to Fischer, 23/11/1942, MPG Archive, Dept. III, Rep. 86 A (Münster), No. 9.
} 
newly founded Institute for Genetic Biology and Race Hygiene at the University of Rostock. ${ }^{139}$

Siegfried Liebau $\left({ }^{*} 1911\right)^{140}$ had worked at the RuSHA and as an adjutant of the SS Medical Academy of Berlin since 1938, from May 1940 to September 1942 he was a personal consultant in the SS Paramedical Office in Berlin. From December 1942 to October 1943 he was detached to the KWI "for professional training in the areas of anthropology, human genetics and race hygiene." 141 The posting of Liebau, whose wife Ingeborg, née von Ekesparre, was a close friend of the Verschuer family, ${ }^{142}$ apparently can be traced back to a request by Verschuer on November 10 , 1942. As will be shown below, Liebau carried out twin studies in Auschwitz during his time at the institute. In the further course of the war he became Chief Physician for the Higher SS and Police Leadership of the Adriatic coastal region and Italy.

The two assistants Grebe and Liebau were joined in the 1942/43 fiscal year by two auxiliary assistants: Karl Joachim Hene, who had entered Gottschaldt's Department for Genetic Psychology as an auxiliary assistant in 1939 and taken his Ph.D. in 1940 with a genetic psychology dissertation about twins in early childhood, returned from military service. Further, the teacher Hans Ritter $\left({ }^{*} 1903\right),{ }^{143}$ who had begun a second university degree in zoology, anthropology and psychology in 1941, but then had been drafted into military service, started work as an auxiliary assistant in Abel's Department for Anthropology, where he dedicated himself to "Gypsy twin research."

Additional reinforcements came in the course of 1943: Karin Magnussen (19081997), working at the KWI-A on a scholarship since 1941, was promoted to an assistantship - during the war period she was the only woman to hold this status. Finally, Heinrich Schade was also hired. Schade, member of the NSDAP and SA since 1931, had taken part, as already mentioned elsewhere, in the first yearly course held at the KWI-A for physicians from the SS in 1934/35. In 1935 he collaborated in the sterilization of the "Rhineland bastards." In the same year he started at the Frankfurt institute as Verschuer's assistant and senior physician. In 1939 he submitted his postdoctoral dissertation about the genetic biological inventory of the population of the Schwalm region, located between Treysa and Alsfeld in Hesse. In December 1942 he moved - on paper - to the KWI-A as Verschuer's

\footnotetext{
${ }^{139}$ For a biography: Lösch, Rasse, p. 566; Klee, Medizin, pp. 265-267; idem., Personenlexikon, p. 198. Cf. Reichsminister für Wissenschaft, Erziehung und Volksbildung to Grebe, 20/1/1945, MPG Archive, Dept. I, Rep. 1 A, No. 2400, p. 264.

${ }^{140}$ For a biography: ibid., p. 371.

${ }^{141}$ SS-Führungshauptamt to KWI-A, 12/11/1942, BArch. Berlin, BDC, RuSHA, Liebau's personal file.

${ }^{142}$ Cf. Massin, Mengele, p. 226 (note 93). On this also Liebau to Reichsführer-SS, 1/12/1935, BArch. Berlin, BDC, RuSHA, Liebau's personnel file (here Verschuer is named as a guarantor for Ingeborg von Ekesparre in the application for permission to engage and marry). The formulation in Verschuer's letter to Fischer of November 1942 (see note 139), however, indicates that Verschuer had not made Liebau's personal acquaintance at the time he was requested.

${ }^{143}$ For a biography: Lösch, Rasse, p. 573.
} 
senior physician. However, because he had been drafted into the Wehrmacht, he was not able to start his new position right away. Not until the turn of the year 1943/44 did Schade come to Berlin, in the course of a military command, ${ }^{144}$ where at times he was able to continue his work of evaluating the genetic biological inventory of the Schwalm region. He must have been detached to the front again later, for he experienced the end of the war as a Yugoslavian prisoner of war. ${ }^{145}$

Of the veteran scientific staff, only Georg Geipel remained at the institute over the entire period of the war. ${ }^{146}$ Otherwise German scientists could only be recruited sporadically, like the "lateral hire" Karin Magnussen, and - as a convalescent - the physician Gerhard Koch (1913-1999). ${ }^{147}$ The ranks were filled instead with foreign guest scholars from neutral or allied states. ${ }^{148}$ Their number initially dropped from five $(1939 / 40)$ to three $(1940 / 41)$, but then rose back up to eight (1942/43) and remained at this level to the end. The staff was joined by several foreign doctoral students. In the period from 1939 to 1945, guest scholars from Bulgaria (Nicolaus Ilkow), Finland (Magister Longfors), India (Sasankar Sekhar Sarkar), Japan (Masataka Takagi, Masaji Kamitake ${ }^{149}$ ), Croatia (Franjo Ivanicek), ${ }^{150}$ the Netherlands (Haring T. Piebenga, Wouter Ströer, Hendrik Scalogne), ${ }^{151}$ Norway (Thordar Quelprud), Portugal (José Ayres de Azevedo), Romania (Marius Sulica), Switzerland

\footnotetext{
${ }^{144}$ Verschuer, Tätigkeitsbericht 1943/44, MPG Archive, Dept. I, Rep. 3, No. 22.

${ }^{145}$ Sparing, Rassenhygiene; Lösch, Rasse, p. 573; Klee, Medizin, p. 267; idem., Personenlexikon, p. 522. - Also appointed to an assistantship in 1943 was the physician Walter Beck, but since he had been called up to the Wehrmacht he was hardly present at the institute.

${ }^{146}$ Max Fischer died in July 1940. Konrad Kühne was listed on paper as a scientific staff member until 1945.

${ }^{147}$ For a biography: Lösch, Rasse, p. 568; Klee, Personenlexikon, p. 323. - Koch joined the Hitler Youth in 1930, the Bund der Artamanen in 1932, then the NS Student League, the NSDAP, the SA and the SS. On October 26, 1942 Verschuer had asked the office of the Army Medical Inspector to grant Koch a 3-month working vacation at the KWI-A. Verschuer to Heeressanitätsinspektion Berlin, 26/10/1942, MPG Archive, Dept. I, Rep. 1 A, No. 2400, p. 238.

${ }^{148}$ Cf. also Fischer's Tätigkeitsbericht 1941/42, MPG Archive, Dept. I, Rep. 3, No. 19.

${ }^{149}$ Masaji Kamitake (1909-1983) had taken his Ph.D. in psychology at the Tokyo Bunri Daigaku University. He studied in Germany as a Humboldt scholar. From 1942 to 1945 he worked as a Japanese editor. After the war he became a professor for psychology at the Kyoiku Daigaku (Teacher's College) in Tokyo. In 1963 he published a work about "New Developmental Psychology," in 1971 one about "Heredity and Environment in their Effect on the Psychological Functions. Studies of Twins." Kamitake worked predominantly with the twin method. Warm thanks to Kazuko Kibata and Yasushi Maruyama for information on Kamitake's biography.

${ }^{150}$ Ivanicek had come to Dahlem as a doctoral student under Fischer. In October 1942 he conceived a plan to acquire his doctorate in medicine with the work on "Australian skulls" entrusted to him by Fischer. In this matter he intended to consult with the anatomist Hermann Stieve (1886-1952) in Berlin. "Apparently Mr. Ivanicek received funds from Croatia to extend his period of study." Verschuer to Fischer, 22/10/1942, MPG Archive, Dept. III, Rep. 86 A (Münster), No. 9. In February 1943 Verschuer wrote: "Ivanicek was absent here for several weeks, now he has turned up again. I think, however, only to conclude his work." Verschuer to Fischer, 9/2/1943, ibid. Cf. also Ivanicek, Beiträge.

${ }^{151}$ Piebenga, Ströer and Scalogne were the editors of the Netherlands Journal for Race Hygiene. Piebenga was supposed to become director of an institute "for the execution of certificates of ancestry and race" in 1942. To make inquiries about him, L. ten Cate, a consultant for questions
} 
(Erik Hug), ${ }^{152}$ Spain (Jésus Cabeza), Turkey (Senhia Tunakan) and Hungary (Mihali Malán, Lajos Csik, Anton Steif, Ladislaus Apor). ${ }^{153}$

The number of doctoral students at the KWI-A oscillated between 21 (1940/41) and eleven (1943/44), whereby the number of those who worked under Fritz Lenz - 14 in 1940/41 - is not included. The comparatively high numbers are deceiving in this case, too, however. Numerous doctoral students had been called up to the Wehrmacht - those who were able to work at the institute with any continuity were generally only the foreign doctoral students and the female doctoral students, whose number oscillated between two and four. ${ }^{154}$

Finally, a glance at the nonscientific personnel, which also grew considerably in the course of reorganizing and expanding the institute. At the beginning of World War II four technical assistants, eight secretaries, one nurse, and five "wage earners" (gardener, driver, keeper, cleaning ladies) had worked at the KWI-A; in 1943/44 there were five technical assistants, 14 secretaries, one photographer, one laboratory technician, one nurse, one auxiliary technical assistant, one caretaker, plus the married couple who worked as caretakers in the External Department for Tuberculosis Research in Sommerfeld, as well as four "wage earners" (keepers, cleaning ladies) and several "temps."155

Despite Verschuer's fears to the contrary, ${ }^{156}$ the institute was able to maintain all of its personnel in the second half of 1944 as well, as impending drafts were postponed for the time being:

Apparently it is primarily thanks to the vigorous action of Prof. Osenberg [Werner Osenberg (1900-1974)] of the Reich Research Council that research is so protected at the moment and should be continued to its full extent. Thus I have increased only the working

of ancestry at the Ministry of the Interior of the Netherlands, paid a visit to the KWI-A in October 1942. Cf. Verschuer to Fischer, 22/10/1942, ibid.

${ }^{152} \mathrm{Hug}$ apparently had a scholarship from the Alexander von Humboldt Foundation. Therefore, so Verschuer to Fischer in October 1942, he would "have to be retained as a guest for a while longer." Verschuer to Fischer, 22/10/1942, ibid. In February 1943 Verschuer then reported: "Hug did not receive a visa for Germany. He asked me to use my influence with the political offices on his behalf, but I was not willing to do so, since I do not know him and, according to everything I have heard about him, cannot take any responsibility for him." Verschuer to Fischer, 9/2/1943, ibid.

${ }^{153}$ According to Lösch, Rasse, p. 577, the guest scholar Ernst Wiedemann was also a foreigner, whereby his nationality is unclear. The doctoral student Martin Haetinger $(* 1915)$ came from Brazil; it is unclear whether or not he was a German citizen. Cf. idem., Stellung.

${ }^{154}$ These were Lieselotte Block (* 1918), Eva Justin (1909-1966), Ruth Rohloff $(* 1920)$, Clärchen Steer and Senhia Tunakan. Inez de Beauclair, who was counted as a doctoral student for the entire period of the war, was on a research trip to China. Lösch, Rasse, p. 571, also lists the doctoral student Margot Irene Oetting in 1943/44 (Cf. Oetting, Haut- und Fingerleisten). - Not taken into consideration here are the female doctoral students working under Lenz, like the social worker Gertrud Maas (*1894), the physicians Hildegard Schwarz and Johanna Schötzau (*1916). Cf. Lösch, Rasse, pp. 563, 570, 574.

${ }^{155}$ Aufstellung über die Personalzusammensetzung 1939/40 and 1943/44, respectively, MPG Archive, Dept. I, Rep. 3, Nos. 17 and. 21, respectively. Also, the salary cards and lists, MPG Archive, Dept. I, Rep. 3, Nos. 2 and 3.

${ }^{156}$ On August 11, 1944 Verschuer still expected that Abel and Gottschaldt would be called up again, and perhaps Nachtsheim as well, who had been ordered for a physical examination. 
hours of the institute - in keeping with the times - but only to such a degree that overstraining is avoided $[\ldots]{ }^{157}$

Verschuer's private household had initially employed foreign civilian workers. In the move from Frankfurt to Berlin in November 1942, the Verschuer family had a Croatian maid. ${ }^{158}$ At the beginning of 1944 the family appears to have employed an additional female "Eastern worker." In late February, Verschuer reported in a letter to Bernhard de Rudder, that there had been "all kinds of sagas with our Russian East worker." "It turns out there had been minor thievery, with which she provided provisions for all kinds of male compatriots [...]." Yet she had been "kept again on probation."159 Shortly thereafter Verschuer again complained of "troubles at home with our Russian (Bolshevik!)." ${ }^{160}$ Besides this, since 1943 at the latest, an additional female "Eastern worker" was working at the neighboring institute. In August 1944, after the renewed proclamation of "total war," Verschuer feared that he would probably "have to give up the two Eastern workers from the house and the institute." 161 Yet it never came to this. In late September 1944 Verschuer wrote to Fischer in Freiburg that the "Russian woman" in service in his household had "run away" - as once before in 1943, and this time "the Russian woman from the institute [...] ran away with her." 162

\subsection{Research Agenda and Research Praxis}

Between September 1939 and November 1942 most of the scientific work at the KWI-A - aside from the External Department for Tuberculosis Research in Sommerfeld and (from 1941) the Department for Experimental Genetic Pathology

\footnotetext{
"And for me, too, it will be a matter of course to put on the gray uniform again when the call is issued to me." Verschuer to Fischer, 11/8/1944, MPG Archive, Dept. III, Rep. 86 A (Münster), No. 9.

${ }^{157}$ Verschuer to Fischer, 31/8/1944, ibid.

${ }^{158}$ Verschuer to de Rudder, 4/11/1942, MPG Archive, Dept. III, Rep. 86 A (Münster), No. 8. On the basis of a recruting agreement Croatian workers came to work in the German Reich voluntar$i l y$, and thus were not among the compulsory laborers brought in from abroad. On the demarcation: Schmuhl, Zwangsarbeit.

${ }^{159}$ Verschuer to de Rudder, 29/2/1944, ibid. "You must be stricter with your Eastern girl," de Rudder responded. They were "on average poor things indeed," but one must not let them get away with anything. "Is she useful otherwise? Now your wife must learn Russian as well as Croatian! By the way, there are nice, simple little dictionaries for household purposes, I picked one up recently." De Rudder to Verschuer, 6/3/1944, ibid. On the "female Eastern household workers," cf. Winkler, "Hauswirtschaftliche Ostarbeiterinnen." For a definition of "Eastern worker," cf. Schmuhl, Zwangsarbeit.

${ }^{160}$ Verschuer to de Rudder, 10/3/1944, MPG Archive, Dept. III, Rep. 86 A (Münster), No. 8.

${ }^{161}$ Verschuer to Fischer, 11/8/1944, MPG Archive, Dept. III, Rep. 86 A (Münster), No. 9.

${ }^{162}$ Verschuer to Fischer, 29/9/1944, ibid. Foreign compulsory laborers were apparently also in service on the Verschuer family estate in Solz. In any case Verschuer reports in his memoirs about the end of the war at Easter 1945 in Solz: "One danger was the many foreign workers, who looted
} 
- came to a standstill due to the fact that so many departmental directors and assistants had been drafted. This was not immediately apparent to the outside world, however. Between 1940 and 1942 the institute still published 43 scientific papers; however, this was the result of a "publication backlog." Most of the publications from this period - to the extent that they were not simply overview papers, conceptual or methodological discussion papers - resulted from research projects that had been concluded before the outbreak of the war. Only very few papers, such as a paper by Karl Diehl and Eugen Fischer about the tuberculosis experiments on rabbits in Sommerfeld and the papers by Hans Nachtsheim about "The State of Convulsion Readiness and Genotype," referred to current projects.

The change came with the new director. Verschuer was successful in getting the departmental director Kurt Gottschaldt and Wolfgang Abel classified as "indispensable," filled the ranks of the assistants with Hans Grebe, Siegfried Liebau, Hans Ritter, and Karin Magnussen and obtained a larger number of foreign guest scholars. And - not to be forgotten - Verschuer achieved a budget hike and solicited considerable third-party funds. Thus research resumed on a large scale from December 1942 on. Of course, this was not immediately reflected in the publication lists. Even so, between 1943 and 1945 the institute in Dahlem produced another 46 publications, whereby - in addition to the general intensification of the war situation - it must be taken into consideration that nearly all of the publications that had accumulated in the prewar period were published at this time. The papers published in the last two years of the war were almost without exception minor works presenting intermediate findings from projects in progress, and some of them were based on material that had been collected previously. A number of publications that had been available in manuscript form or were even in print were lost in the chaos of the war's end; others were not completed before the collapse of the Third Reich. Some of these papers were still published after World War II, for others this did not seem opportune because they were all too closely associated with the state crimes of National Socialist Germany.

In the final 2 years of the war, the shift in emphases between the fields of research of the institute in Dahlem, observable since 1933, continued at a faster pace. Genetic pathology moved to center stage with 19 publications - and this was, so to speak, only the tip of iceberg, as several large-scale projects in the field of genetic pathology never found their way to publication. This dominance of genetic pathology had various reasons: First, the two departments that had been able to keep up their operations in the first war years, that is, the External Department for Tuberculosis Research and the Department for Experimental Genetic Pathology after 1941 - both worked in this area. Second, the focus of interest of the new director, Verschuer, remained on genetic pathology. Third, in bringing Hans Grebe from

and took revenge. Fortunately our farmer Cornelius had always treated them well, so that nothing bad happened on our estate." Verschuer, Erbe - Umwelt - Führung, "Direktor des KaiserWilhelm-Institutes für Anthropologie, menschliche Erblehre und Eugenik (seit 1942)" section, p. 16, MPG Archive, Dept. III, Rep. 86 A, Nos. 3-1. Cf. on compulsory workers in the service of the KWG Strebel/Wagner, Zwangsarbeit. 
Frankfurt to Dahlem, Verschuer had an assistant who, because of a project for the collection of stillborn fetuses in progress since the prewar period, and because of his postdoctoral dissertation about chondrodysplasia, had a rich fund of pathological material at his disposal, which could be evaluated without any great cost. Fourth, through the activities of preparing assessments and evaluations, individual cases of genetic pathological interest (including all of the important genealogical information required for their genetic pathological evaluation) came to the attention of the researchers in Dahlem. Fifth and finally, the findings of genetic pathology promised a direct practical utility with regard to the measures of both genetic health policy, as well as eugenic sterilization, marriage bans in accordance with the "marriage health law," the allocation of "matrimony loans" and so on. The KWI-A extolled this practical aspect of genetic pathology research quite audibly, which was evident in the mere fact that the research application which covered the major portion of the work in this area bore the keyword "race hygiene." 163 In total it can be asserted that the research field of genetic pathology increasingly pushed its way into race hygiene over the course of World War II: there was hardly a genetic pathology study that was not oriented to genetic health policy, and hardly a race hygiene paper without clear references to genetic pathology. ${ }^{164}$ The trend toward specialization observed in the final years before World War II, which inclined to lead race hygiene and genetic pathology (and race biology) away from each other, ${ }^{165}$ was reversed at the KWI-A from 1943 on.

For a concrete example, in the years 1943-1945 there were nine research contracts with the keywords:

- "genetic pathology research" (Hans Nachtsheim)

- "tuberculosis" (Karl Diehl)

- "specific proteins" (Otmar von Verschuer)

- "eye color" (Karin Magnussen)

- "twin camps" (Kurt Gottschaldt)

- "race hygiene" (Hans Grebe et al.)

- "genetic biological inventory" (Heinrich Schade)

- "stillborn fetuses" (Grebe)

- "pneumoconiosis" (Grebe) $)^{166}$

\footnotetext{
${ }^{163}$ Cf. Bericht über das Forschungsprojekt "Rassenhygiene," n.d. [March 1944], BArch. Koblenz, R 73/15.342,p. 67; ibid. [October 1944], ibid., p. 41 (a dissertation by Klaus Gnirke, "Kasuistischer Beitrag zur Klinik und erbpathologie der Myotonia congenita" ["Casuistic Contribution to the Clinical and Genetic Pathology of Myotonia congenita"] is also announced here).

${ }^{164}$ As, e.g. Maas, Kinderzahl.

${ }^{165}$ Weingart/Kroll/Bayertz, Rasse, pp. $436 \mathrm{f}$.

${ }^{166}$ Wehrmacht contract numbers: pp. 4891-5376 (1591/10) - III/43 ("genetic pathology research"), SS 4891-5377 (1592/10) - III/43 ("tuberculosis"), S 4891-5378 (1593/10) - III/43 ("specific proteins"), K RO/RFR-0295/1594/10 - III/43 ("eye color"), K RO/RFR-0296/1595/10 - III/43 ("twin camps"), K RO/RFR-0297/1596/10 - III/43 ("race hygiene"), K RO/RFR-0298/1597/10 III/43 ("genetic biological inventory"), K RO/RFR-0299/1598/10 - III/43 ("stillborn fetuses") and K RO/RFR-0300/1599/10 - III/43 ("pneumoconiosis").
} 
Five of these nine research contracts - "genetic pathology research," "tuberculosis," "race hygiene," "stillborn fetuses" and "pneumoconiosis" - were located directly in the field of genetic pathology, one further - "genetic biological inventory" - had strong bearings on genetic pathology. This illustrates the dominance of genetic pathology even more strongly than the analysis of the publication list. The genetics of normal attributes, even and especially under the aspect of race was relegated down to second place, with two research contracts - "specific proteins" and "eye color" - and a total of 13 publications. ${ }^{167}$

Weighting the individual research projects according to their financial, political, and research-strategic value, it becomes apparent that from 1943 on, four areas were of fundamental importance for the future of the institute: comparative genetic pathology (Nachtsheim), research on the heredity of tuberculosis (Diehl), the project on the phenogenetics of eye color (Magnussen), and the project to develop a serological race test (Verschuer). Their progress determined whether the budget could be fixed at a high level, whether sources of financing outside of the regular budget kept flowing, and whether research operations could be maintained in their entirety. They decided whether the project of phenogenetics, above all its integration into general genetics and biology, would succeed. And they were eminently important for genetic health and race policy.

\subsubsection{Genetic Pathology and Race Hygiene}

Verschuer energetically pushed ahead with the concept of phenogenetics developed by Fischer, but placed the emphasis on genetic pathology research, ${ }^{168}$ whereby, of course, he consequently conceived of genetic pathology as "medical genetics," thus embedding it in general human genetics. Besides, Verschuer understood genetic pathology as a principle encompassing and penetrating all subdisciplines of medicine and urged - in keeping with his concept of the "genetic doctor" - that it be indulged generously in both specialized and general medical practice. With his attempts to influence the medical students' conditions of study and examinations, his house journal Der Erbarzt, and - since 1937 - Fortschritte auf dem Gebiet der Erbpathologie, Rassenhygiene und ihrer Grenzgebiete ("Advances in the Field of Genetic Pathology, Race Hygiene and Their Boundary Areas"), ${ }^{169}$ and finally with

\footnotetext{
${ }^{167}$ The remaining areas had nearly no importance at all: In the area of geographic and paleoanthropology six papers appeared (mainly connected with colonial science research on "White Africa"); four papers dealt with subjects that were decidedly race hygiene; four works were dedicated to conceptual and methodological issues. No papers appeared on genetic psychology.

${ }^{168}$ Cf. e.g. Verschuer to Stadtmüller, 15/11/1942, MPG Archive, Dept. V a, Rep. 16, No. 2.

${ }^{169}$ Verschuer coedited this journal with the psychiatrist Johannes Schottky (*1902), director of the Hildburghausen Sanatorium in Thuringia. Cf. Klee, Personenlexikon, p. 558.
} 
his Leitfaden der Rassenhygiene ("Manual of Race Hygiene"), ${ }^{170}$ Verschuer contributed to the process of making the findings of genetic pathology research flow into practice.

The orientation on genetic pathology was also expressed in the erection of a genetic biological examination office in the attic of the KWI-A, which was to be expanded to a "clinical and polyclinical station [...] in order to be able to continue the activities of consulting and producing expert opinions and also genetic clinical and genetic pathology research." 171 Verschuer had already operated such an office in Frankfurt - the model for it had been the "Polyclinic for the Care of Genes and Race" in Berlin-Charlottenburg, which Verschuer had run in 1934/35. From Frankfurt he brought nurse Emmi Nierhaus ( $\left.{ }^{*} 1880\right)$ from the Protestant Social Services Association (Evangelischer Diakonieverein), who not only took over the administration of the institute as his "right hand," but also provided nursing care for the examination office. ${ }^{172}$

"For as intensive specialized study of the research material as possible" Verschuer further founded a "Genetic Pathology Working Group," to which he invited - besides the staff of the institute - prominent representatives of "pathological anatomy, radiology and all clinical specialities." This working group, which convened for the first time in March 1943, was also supposed to "discuss difficult questions in the practical care of genes and race and prepare the basic decisions for the state offices." ${ }^{\prime 13}$ In his journal Erbarzt, too, Verschuer emphasized the Genetic Pathology Working Group's orientation to practice: Over and again he was "enlisted for genetic medical consultations and evaluations, by the Health Offices as a genetic biology consultant, and by the Hereditary Health Courts and Appellate

\footnotetext{
${ }^{170}$ The 2nd edn. of Leitfaden der Rassenhygiene appeared in 1944. In 1943 Verschuer reported that a French edition was in printing, and a Portuguese one in preparation. Cf. Verschuer, Tätigkeitsbericht 1942/43, MPG Archive, Dept. I, Rep. 3, No. 20.

${ }^{171}$ Verschuer to the Evangelischer Diakonieverein, 22/5/1942, Archiv des Evangelischen Diakonievereins Zehlendorf, W 3848 (pre-archive). Cf. also Verschuer, Tätigkeitsbericht 1942/43, MPG Archive, Dept. I, Rep. 3, No. 20.

${ }^{172}$ Emmi Nierhaus started at Verschuer's institute in Frankfurt in September 1937, followed him to Dahlem in December 1942 and from there to the lay-by in Solm. After the war Nierhaus continued to work as Verschuer's assistant, from July 1947 on, officially in the service of Protestant Social Services (Evangelisches Hilfswerk). After a short interruption in 1951/52 she joined Verschuer at the University of Münster. Her responsibilities proceed from a letter by Verschuer from the year 1952: "I would like to assign nurse Emmi the same group of duties she used to perform for me in Frankfurt and then in Berlin in such an excellent manner: it means a great deal to me that those people who come to use for scientific examination (e.g. twins), for evaluation (e.g. paternity certificates) or for their own consulting and examinations (e.g. marriage counseling), enjoy nursing care. The help of a nurse during the examinations currently in progress at the institute would thus have the highest priority. Added to this would be the economic direction and administration of the institute, along with the many individual tasks associated with these duties, in which nurse Emmi has proved particularly invaluable in the past." Verschuer to Oberin Sprenger, Evangelischer Diakonieverein, 26/2/1952, Archiv des Evangelischen Diakonievereins Zehlendorf, W 3848 (pre-archive).
}

${ }^{173}$ Verschuer, Tätigkeitsbericht 1942/43, MPG Archive, Dept. I, Rep. 3, No. 20. 
Courts and other offices contracted to carry out race hygiene measures, as a chief evaluator." ${ }^{174}$ In Frankfurt, whenever a specialized medical examination became necessary, he had turned to his specialist friends and their clinics - the working group in Dahlem was supposed to serve an equivalent function. In his report about the 1943/44 fiscal year Verschuer reported that the Genetic Pathology Working Group had held "several sessions [...] at which not only scientific cases from the field of genetic pathology were presented and discussed, but also practical issues of the care of genes and race debated, in order to provide to the Reich Ministry of the Interior and the Hereditary Health Appellate Courts a position on evaluations." 175 The Erbarzt published the protocols of two meetings of the working group, those held on March 17 and May 19. ${ }^{176}$ In his memoirs, published in 1993, Gerhard Koch stated that he attended a further meeting of the Genetic Pathology Working Group in July or August 1943, in which the subjects were hip luxation and club foot and whose participants included the internist Friedrich Wilhelm Bremer, the orthopedic surgeon Lothar Kreuz (1888-1969), ${ }^{177}$ director of Oskar Helene Heim and the Orthopedic Clinic of the University of Berlin, and the pathologist Robert Roessle (1876-1956). ${ }^{178}$ On this occasion Kreuz claimed he advocated the elimination of these two congenital disabilities from the catalog of indications in the $\mathrm{GzVeN}$; his proposal had been agreed to, even "by the high-ranking medical officers of the army and Waffen-SS attending this session, whose names were not known to me." Koch presumes that the publication of the protocols of the meeting was "suppressed by the censors." 179 This could in fact be the reason why - in contrast to the original proclamation - after the first two, no further protocols of meetings by the Genetic Pathology Working Group were published. However, it must be taken into consideration that Koch's account is not confirmed by any other source and that Koch has a tendency to exaggerate the frictions between genetic pathology research at the institute in Dahlem and NS genetic health policy, not to mention the importance of censorship.

A key role in the area of genetic pathology was played by Hans Grebe, who came to Berlin from Frankfurt with Verschuer. It is essentially due to his influence that a new emphasis on the field of the differential diagnosis of congenital defects developed at the KWI-A from 1943 on. In 1938 Grebe had begun with comprehensive studies on chondrodysplasia (hereditary disproportional dwarfism). He wrote a circular to 98 health offices in southern, western, and northwestern Germany,

\footnotetext{
${ }^{174}$ Verschuer, Erbpathologische Arbeitsgemeinschaft, p. 91.

${ }^{175}$ Verschuer, Tätigkeitsbericht 1943/44, MPG Archive, Dept. I, Rep. 3, No. 22.

${ }^{176}$ Grebe, Hydrophthalmus; idem., Erbpathologische Arbeitsgemeinschaft.

${ }^{177}$ For a biography: Fuchs, "Körperbehinderte," pp. 126-130; Klee, Personenlexikon, p. 340.

${ }^{178}$ For a biography: ibid., p. 503.

${ }^{179}$ Koch, Humangenetik, p. 115. At Verschuer's institute in Frankfurt intensive work on hip luxation and club foot had been performed (cf. e.g. Dönges, Fragen; Schwarzweller, Beitrag), and at the DFA in Munich, too, these topics were dealt with during the war (cf. Idelberger, Frage der anlagemäßigen Entstehung; idem., Frage der exogenen Entstehung).
} 
with which the institute in Frankfurt had already been in contact regarding further professional training for medical officers. Eighty-five health offices responded to this survey and reported a total of 115 people with "dwarfism," nearly all of whom Grebe visited personally and subjected to a thorough clinical and radiological examination, together with the members of their families (parents, siblings, children, uncles, aunts, nieces, nephews, and cousins). Family tables were produced on the basis of registry office and church records, whereby particular attention was paid to the question of whether the parents were related by blood. For the purpose of comparison, Grebe consulted the specimens of miscarried and stillborn chrondodysplastic fetuses that had been dissected at the Pathological Institute of the University of Frankfurt in the years from 1936 to $1939 .{ }^{180}$ Grebe had to discontinue his work after the beginning of the war because he was called up for military service. In summer 1942 - as previously mentioned, Grebe had been discharged from the Wehrmacht because he was seriously wounded - the "main part" of the work performed at the University of Frankfurt was submitted as his postdoctoral thesis. The manuscript was sent to Thieme-Verlag in Leipzig for publication, but the proofs were destroyed there by a bombing - not until 1955 was the work published in Analecta Genetica, largely unchanged, by Luigi Gedda (1902-2000), the founder and director of the Mendel Institute in Rome. ${ }^{181}$

Grebe had examined a total of 118 families with around 9,350 persons, ${ }^{182}$ frequently against the bitter opposition of the subjects. One of the probands, who had been sterilized at the age of 41 in 1938, as Grebe reports casually in 1955, had reacted to "a clinical and radiological examination and especially the production of photographs [...] with the greatest resistance." Among these probands, he continued, there was the "highest degree of mental sensitivity, which was also shared by most of the members of the family." 183 Of one 43-year-old subject he writes that she was "very sensitive mentally" and seemed "decidedly depressive. For instance, during the examination, against which she put up vehement resistance, she began to cry. During a later visit, too, her mental behavior seemed melancholy." ${ }^{184}$ Only in the case of a 17-year-old girl, who had been sterilized in spite of an appeal to the Hereditary Health Court, did Grebe express a degree of sympathy: "The resistance brought against our examination was particularly great under these circumstances." 185 The boundaries between voluntariness and compulsion were blurred to the extent that some health offices used Grebe's survey to request an opinion as to whether a marriageability certificate could be issued for certain probands. ${ }^{186}$ Occasionally a Hereditary Health

\footnotetext{
${ }^{180}$ Grebe, Chondrodysplasie, pp. 53-55.

${ }^{181}$ Ibid., pp. VII-VIII.

${ }^{182}$ Ibid., pp. $355-366$.

${ }^{183}$ Ibid., p. 79. Grebe did not even hesitate to secretly take a picture of a female subject whose behavior was guarded and suspicious. Ibid., p. 69.

${ }^{184}$ Ibid., p. 116.

${ }^{185}$ Ibid., p. 202. Further indications of resistance on, e.g., pp. 86, 98, 100 p. 114, 119, 123.

${ }^{186} \mathrm{Cf}$. e.g. ibid., p. 105: "With the negative family finding and the particular professional prowess of the proband, who also successfully graduated from a rural vocational school," in this case
} 
Court requested that the Frankfurt Institute for Genetic Biology and Race Hygiene provide an evaluation in accordance with the $\mathrm{GzVeN}$ - in these cases it was not possible for the subjects to refuse an examination. As Grebe adhered strictly to his analysis of the conditions of heredity, he sometimes took a position against sterilization, ${ }^{187}$ yet this did not change the fact that in this situation he confronted his subjects in compulsory proceedings as an officially empowered evaluator with comprehensive powers of attorney. This constituted a transgression of the boundaries of scientific ethics of major importance, both potential and in principle.

The material Grebe had collected in the course of his study of chondrodysplasia constituted the basis for a series of publications in the years 1942-1945, as he had run across an abundance of additional physical defects, mental disabilities, and mental disorders in his comprehensive genealogical studies. ${ }^{188}$ This material increased when, after completing his postdoctoral dissertation, Grebe set about recording miscarried and stillborn fetuses on a large scale. By March 1943 he had examined nearly 100 families who had produced a stillborn child with a serious defect. ${ }^{189}$ Verschuer's activity report for the 1943/44 fiscal year relates:

Grebe concluded a major family research project using a non-selected series of deformed stillborn fetuses. Generally speaking he was able to prove that heritability plays a much greater role in the problem of stillbirths than was previously presumed. For the first time he was able to prove that certain forms of congenital defects are hereditary. ${ }^{190}$

Thus Grebe, proceeding from his collection of stillbirths, described three families in which multiple intestinal deformities had occurred (stenoses, atresias, ventricles, cysts). ${ }^{191}$ In 1944 he published a paper about the problem of a genetic disposition for hernias (inguinal and umbilical), based on observations of twins and families. ${ }^{192}$ Grebe attempted to prove that a hereditary factor was involved in the etiology of both cases. In other cases he endeavored to illuminate the hereditary precisely. In 1944, for instance, he published an essay that proceeded from the "Stillbirths" project, on the emergence of arhinencephaly (absence of olfactory tract, olfactory bulbs, and frequently the frontal lobe of the brain), whereby he presumed an

Grebe took a position for issuing a marriageability certificate. A case with similar circumstances is depicted on p. 182.

${ }^{187} \mathrm{Cf}$., for instance, ibid., pp. 104, 139. Perusing the book, indications of more than twenty sterilization trials are found, whereby in one case (p. 186) the application was supposed to have been submitted by the subject herself.

${ }^{188}$ Cf. Grebe, Fistula; idem., Struma; idem., Erblichkeit; idem., Akrocephalosyndaktylie; idem., Lipomatosis.

${ }^{189}$ Verschuer, Bericht über das Projekt "Totgeburten” für die Zeit vom 1/10/1943 bis zum 31/3/1944, 17/9/1944, BArch. Koblenz, R 73/15.342, p. 57.

${ }^{190}$ Verschuer, Tätigkeitsbericht 1943/44, MPG Archive, Dept. I, Rep. 3, No. 22. Cf. also Grebe, Todesursache.

${ }^{191}$ Grebe, Erblichkeit.

${ }^{192}$ Grebe, Hernien, pp. 66f. This study was based on a collection of material Grebe had collected during his previous work at the Horst Wessel Hospital and on cases from the twin files in Dahlem. It continued earlier works by Weitz and Verschuer. 
"irregularly dominant genetic disposition." ${ }^{193}$ In the same year he published a major paper on acrocephalosyndactylia (a syndrome characterized by skull deformation and webbing of the fingers). With reference to the etiology of this syndrome he rejected all "exogenous attempts at explanation (above all deficient amnion, lues and hypophysis damage)." Grebe assumed a specific mutation and concluded that "no race hygiene measures proceed from acrocephalosyndactylia at this time." 194

In all of his research Grebe endeavored to make as precise a differential diagnosis as possible. ${ }^{195} \mathrm{He}$ assumed that one congenital defect could have very different genetic or even exogenous causes (heterogeny). Verschuer emphasized the importance of Grebe's research in this direction in his activity report for the 1942/43 fiscal year:

In the area of the typical clinical picture [of chondrodysplasia] it was possible to establish several gene types that could be differentiated clinically and genetically. On the margins of the typical complex of symptoms there are many other genetic conditions of the cartilageskeletal system, some of which could be observed and described for the first time. The project thus yielded a very far-reaching heterogeny, which is of fundamental importance. ${ }^{196}$

This finding made it seem very important to demarcate the different clinical occurrences as precisely as possible, to explain the genes responsible in each of the hereditary forms, and to reveal genes that were manifested to a hardly perceptible degree or not at all. In the context of his study about chondrodysplasia Grebe published a family study in which he pursued the question as to whether the heterozygotic carriers of the recessive gene for chondrodysplasia could be recognized on the basis of minor, nonpathological varieties. In x-rays he established that the heterozygotic family members showed minimal changes in the bone structure of the hands and feet. "But should it not be possible," Grebe asked at the close of his article, "to find a way to recognize the heterozygotes in the future, for other recessive genetic conditions as well?" For the "practical care of genes and race" the importance of this question "could not be underestimated."197

Yet another study by Grebe of the year 1943 must be viewed against the background of his search for stigmata. This particular work dealt with a family with an increased frequency of lipomatosis (painless symmetrical diffuse deposits of fat), but also "mental anomalies (schizophrenia, schizoid psychopathy, feeble-mindedness to greater or lesser degree, suicide, epileptic-type fits, melancholy)" as well as physical deformities (chondrohypoplasy, microcephaly, wryneck, hernias). In this case, however Grebe discarded the hypothesis of a genetic connection. Rather, he traced the coincidence of the various anomalies back to "sifting by mating." Moreover, it was possible "that the effect of one or more pathological genes on the manifestation of other genes resulted from the particular frequency of anomalies in the family described." 198

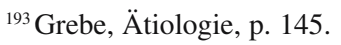

${ }^{194}$ Grebe, Akrocephalosyndaktylie, pp. 259 f. Cf. idem., Untersuchungen, which deals with disorders of the papillary lines in cases of syndactylia.

${ }^{195} \mathrm{Cf}$. also Grebe, Differentialdiagnose; idem./Weisswange, Chondrodysplasie.

${ }^{196}$ Verschuer, Tätigkeitsbericht 1942/43, MPG Archive, Dept. I, Rep. 3, No. 20.

${ }^{197}$ Grebe, Nachweis, p. 9.

${ }^{198}$ Grebe, Lipomatosis, p. 62.
} 
In a further essay entirely tailored to practical race hygiene, in 1943 Grebe discussed the question of how high the risk should be estimated that a mother who already had experienced a miscarriage or stillbirth would give birth to yet another child with defects. In the case of very serious defects that made survival impossible, Grebe summarized his considerations, "more or less complete destruction" resulted on its own. However, a "complete elimination" of all genes responsible for defects was not possible, "first of all because only some of the carriers of very frequent, irregularly dominant and recessive genes become phenically ill, and further, because constant new generation through mutation is possible." After all in many cases the probability that a further deformed child would be born after the birth of a non-viable, seriously deformed child was so low that there was no need to advise against a new pregnancy. And even for minor changes "that can hardly be addressed as defects" there was no need to take action. "On the other hand, great misgivings about the conception of additional children must be expressed in cases of defects which allow the affected child to survive and reproduce, but reduce to some degree the capability of the adult to work or perform military service." In every consultation, however, "the total value of the given family [must be] considered."199

Methodologically speaking, genetic pathology research at the KWI-A was committed to higher Mendelism at the time of the World War II, and its objectives thus differed from those of practical race hygiene. In terms of contents a clear emphasis on the area of physical defects emerged, due above all to Grebe's research interests. In the Department for Race Hygiene the research "about the heritability of deaf-muteness and the race hygiene prospects of its prevention" 200 begun in the prewar period was continued. Hereditary blindness, too, remained an object of interest. ${ }^{201}$ Finally, these were joined by the research on epilepsy in the Department for Experimental Genetic Pathology. This constitution of emphases entailed a clear division of labor with the German Research Institute for Psychiatry and the Kaiser Wilhelm Institute for Brain Research in Berlin-Buch, both of which, closely connected with the Nazi "euthanasia," were concerned with the differential diagnostics of the various forms of mental disability, schizophrenia, and neurodegenerative diseases at this time. This area played no further role at the KWI-A during World War II. ${ }^{202}$

\footnotetext{
${ }^{199}$ Grebe, Mißbildung, pp. $488 \mathrm{f}$.

${ }^{200}$ Fischer, Tätigkeitsbericht 1939/40, MPG Archive, Dept. I, Rep. 3, No. 17.

${ }^{201}$ Cf. Grebe, Häufigkeit; idem., Hydrophthalmus.

${ }^{202}$ However, the typed list of publications for the year 1943/44 lists an essay by Hans Grebe about "Eine Sonderform der Athetose mit Hörstörung und Schwachsinn" ("A Special Form of Athetosis with Hearing Defects and Feeble-Mindedness)", which was to be published in the PsychiatrischNeurologische Wochenschrift, but had not been published by the end of the war. Gertrud Veit was listed as coauthor; she may be identical to the author of a short study "Über Dornfortsatzbrüche" ("About Breaks of the Spinal Process") (1936). Athetoses (clinical pictures with incessant, slow, involuntary movements of the members) were the focus of interest in the cooperation between the Histopathological Department of the KWI for Brain Research unter Julius Hallervorden and the T4 "research center" in the State Institution at Brandenburg-Görden under Hans Heinze. Cf. Schmuhl, Hirnforschung. - Under the umbrella of the Department for Race Hygiene, in 1942 Werner Wolfslast published a genealogical study about Pelizaeus-Merzbacher syndrome, a condition
} 
Yet the withdrawal from the areas of psychiatry and neurology was only in part the result of a conscious demarcation of the fields of work. It was much more a result of the fact that the large-scale project on the genetic biological inventory of 18 peasant villages in the Schwalm region of Hesse, which was begun in Frankfurt and was supposed to be continued in Dahlem, was not making any headway. Originally, the project was one of those taken on by Walter Scheidt as part of the "German Race Science" campaign. At Scheidt's request church records had been catalogued, scholars had begun to compile family tables from the around 65,000 excerpts from church records - the declared objective was to establish the genealogy of the peasant population of Schwalm from 1575 to the present. In 1935 Scheidt had turned the project over to the Frankfurt Institute for Genetic Biology and Race hygiene, which used funds from the Reich Committee for National Health Service to hire an assistant to complete the family tables. Further, Verschuer's institute set about recording the living population in these villages, whereby not only the usual anthropometric examinations took place, "but rather beyond these also comprehensive clinical-physiological and pathological findings [were to be] recorded" - this was the reason for handing the project's direction over to the physician Heinrich Schade. As the counterpart of the long-time resident population of the Schwalm region, a parallel genetic biological inventory of the city of Frankfurt south of the Main was to be carried out using the same methodology. The objective of the genetic biological inventories was to link together the fields of race anthropology, genetic pathology, and race hygiene:

These studies are suitable for elucidating even precisely this difficult question of the meaning of race, miscegenation and constitution for pathological events in the human body. Moreover it will be possible, on the basis of such comprehensive genetic biological material on a population, to study theoretical issues of the genetic biology of humans, whose study was not previously possible because the necessary data were lacking. Genetic biological inventory goes beyond this in performing a quite essential service to the practical tasks of the care of genes and race, by supplying data for the further expansion of sterilization, marriage consultation and other measures. ${ }^{203}$

Schade and his staff had been working in the Schwalm region since winter 1935/36 - with the active support of the district administration, the mayors, the health offices, the schools, and the party offices. In February 1936 they had concluded their studies in two villages. In addition they evaluated the patient files of the relevant institutions of the treatment and care, hospitals, welfare offices, and practical physicians. All findings were recorded in the family tables and files, which were made accessible by a personal card index.

named for the neurologists Friedrich Pelizaeus (1850-1917) and Ludwig Merzbacher (18751942) with nystagmus, progressive psychomotoric retardation and other neurological symptoms (Wolfslast, Sippe). The paper was based on examinations Wolfslast had performed back in 1936 under the direction of Horst Geyer. In 1942 Grebe had published a case of "Dysplasia of the Right Half of the Body in One of Two Identical Twin Sisters" (Grebe, Dysplasie).

${ }^{203}$ Verschuer to Deutsche Forschungsgemeinschaft, 20/2/1936, BArch. Koblenz, R 73/15.341, pp. 31-34, quotes: p. 32f. 
In late 1937 Schade - with financial support from the DFG - had over 10,000 excerpts from the case histories of the University Clinics in Marburg and the files of the Ziegenhain Health Office, the State Insurance Institute in Kassel and from army physicals. Schade and his colleague Günter Burkert had personally examined 1,124 patients. ${ }^{204}$ By March 1939 over 15,000 excerpts from patient files and Health Office certificates had been produced. ${ }^{205}$ In the framework of the project, Schade's interest was directed primarily to the distribution of "feeble-mindedness" in the "inbreeding area" of the Schwalm region, with a strong practical orientation to race hygiene. ${ }^{206}$ Burkert dealt with "acts of selection" through immigration to and emigration from the Schwalm region. ${ }^{207}$ A study about the "character and aptitude of the Schwalm population" apparently was never concluded. The project staff member Heinz Koslowski performed anthropological studies in one of the region's communities, which had been founded as a Hugenot settlement, establishing there "demonstrable differences with regard to the population of purely German descent." 208

Schade submitted his postdoctoral thesis about the genetic biological inventory of the Schwalm region in 1939 - it appeared in print in $1950 .{ }^{209}$ At the beginning of the war the evaluation of the daunting mountain of material was far from concluded, however. Schade was drafted into military service. In December 1942 - on paper - he followed his mentor Verschuer to Dahlem, but continued to serve as a surgeon major on the front and was not able to work at the institute himself. A new "auxiliary statistical assistant" continued to evaluate the genealogical, anthropological and medical data. ${ }^{210}$ Not until the turn of the year 1943/44 could Schade, as mentioned above, come to Berlin in the course of a military command and resume his work at the institute. In his activity report for the fiscal year 1943/44 Verschuer reported that Schade had

[T]he essential task of processing the great amount of material on the genetic biological inventory for an old-established peasant population (from the pre-war period) continues to be sponsored. The population movements over 340 years have been established, the average burden with numerous illnesses determined and the question as to the importance of heredity for early invalidity investigated. ${ }^{211}$

\footnotetext{
${ }^{204}$ Verschuer, Bericht über die im Jahre 1937 durchgeführten und für das Jahr 1938 geplanten Forschungen, 21/12/1937, BArch. Koblenz, R 73/15.342, pp. 162-165, here: p. 164. Cf. Schade, Erbbiologische Bestandsaufnahme.

${ }^{205}$ Verschuer, Bericht über die im Jahre 1938 durchgeführten und für das Jahr 1939 geplanten Forschungen, 9/3/1939, BArch. Koblenz, R 73/15.342, pp. 125-127, here: p. 126.

${ }^{206}$ Schade, Häufigkeit; idem./Küper, Schwachsinn. Cf. also idem., Beitrag; idem., Befunde.

${ }^{207}$ Burkert, Auslesevorgänge.

${ }^{208}$ Verschuer, Bericht über die im Jahre 1938 durchgeführten und für das Jahr 1939 geplanten Forschungen, 9/3/1939, BArch. Koblenz, R 73/15.342, pp. 125-127, here: p. 127. Cf. Koslowski, Einfügung. The genetic psychology part of the project was to be carried out by a "Miss Dorer."

${ }^{209}$ Schade, Ergebnisse. Cf. also idem., Untersuchung.

${ }^{210}$ Verschuer, Bericht über das Projekt "Erbbiologische Bestandsaufnahme," n.d. [September 1943], BArch. Koblenz, R 73/15.342, p. 59.

${ }^{211}$ Verschuer, Tätigkeitsbericht 1943/44, MPG Archive, Dept. I, Rep. 3, No. 22.
} 
Two publications that had been announced never came to be, however. ${ }^{212}$ Consequently there was a great deal of material available at the KWI-A that could have been evaluated with regard to aspects of genetic pathology, in particular with regard to mental disabilities, had there not been a dearth of personnel.

In other areas, too, such as internal medicine, for practical reasons it was hardly possible to perform genetic pathology research during the war. Back in 1938 Grebe had begun a large-scale study in Frankfurt on the question of a "constitutional conditionality" of pneumoconiosis ("black lung" disease) on behalf of the Reich Labor Ministry. Through his service at the front this study was interrupted for 3 years and was supposed to be brought to its conclusion in Dahlem in 1943. But the air war made it impossible "to perform systematic examinations in the Ruhr area at this time, whence the majority of the cases originated," 213 such that completion of the study was delayed even further. By then Grebe had recorded over 20,000 cases of black lung, which had been treated in social miner's hospitals or discovered during the series of x-ray examinations performed by the SS. The twins had been determined by means of inquiries at the offices of vital statistics. Grebe had contacted over 100 twins and requested file data and photographs. The clinical examination of the twins was interrupted by the start of the war, however, and the study had run aground in the second half of the war.

In the area of infectious diseases, genetic pathological research in the last 2 years of the war concentrated exclusively on tuberculosis research, after another longterm project had remained without any concrete results. Around 1937 Verschuer, together with the biologist Richard Prigge (1896-1967) ${ }^{214}$ of the State Institute for Experimental Therapy in Frankfurt, had begun a "heredity experiment" on the "natural resistance of the guinea pig to diphteria toxin." ${ }^{215}$ In their final report published in 1943, Prigge and Verschuer reached the conclusion that "the question of hereditary differences in resistance to diptheria toxin in the guinea pig clearly must be answered in the negative." 216 Of the 769 guinea pigs tested, only two survived, which had been "taken into breeding." 217 The production of a diptheria-resistant

\footnotetext{
${ }^{212}$ Erkrankungsstatistik einer Wohnbevölkerung ("Illness Statistics of a Residential Population") and Bevölkerungsbewegung in drei Jahrhunderten in acht Dörfern ("Population Movement over Three Centuries in Eight Villages"). Cf. Verschuer, Bericht über das Projekt "Erbbiologische Bestandsaufnahme," n.d. [October 1944], BArch. Koblenz, R 73/15.342, p. 40.

${ }^{213}$ Verschuer, Bericht über das Projekt "Staublungenkranke," n.d. [September 1943], ibid., p. 58. Through Grebe's move to Rostock the "Pneumoconiosis" and "Stillbirths" projects were delayed further. Cf. Verschuer to Präsident des Reichsforschungsrates, 4/10/1944, ibid., p. 37.

${ }^{214}$ For a biography: Klee, Personenlexikon, p. 473. On the inception of the project cf. Verschuer, Bericht über die im Jahre 1938 durchgeführten und für das Jahr 1939 geplanten Forschungen, 9/3/1939, BArch. Koblenz, R 73/15.342, pp. 125-127, here: p. 125 v (by this time ten pairs of twins with pneumoconiosis had been discovered).

${ }^{215}$ Verschuer, Tätigkeitsbericht 1942/43, MPG Archive, Dept. I, Rep. 3, No. 20.

${ }^{216}$ Prigge/Verschuer, Resistenzunterschiede, p. 162.

${ }^{217}$ Verschuer, Tätigkeitsbericht 1943/44, MPG Archive, Dept. I, Rep. 3, No. 22. Cf. Prigge/ Verschuer, Resistenzunterschiede, p. 162 (note 1).
} 
guinea pig through pure breeding was not successful, however. Instead, it seemed that the breeding of a tuberculosis-resistant rabbit was within reach.

\subsubsection{Tuberculosis Research}

Since tuberculosis research using the twin method had hit a dead end in the 1930s, ${ }^{218}$ Karl and Anne Diehl - in close collaboration with Verschuer and Fischer - had been experimenting with rabbits in the "Waldhaus Charlottenburg" since 1934. ${ }^{219}$ Diehl infected his experimental animals with a constant strain of the bovine tuberculosis bacillum by means of intravenous injection, but not until sufficient progeny were available for further breeding. The infected animals were held in a secluded stall and dissected after their death. Clear differences, interpreted as conditioned by heredity, became apparent as regarded the time of survival after injection and the infestation of the individual organs. Interest was directed primarily to two breeding lines - the one, "central" type developed a serious tuberculosis of the lung, while the other organs were hardly affected at all; in the other, "peripheral" type, by contrast, the sources of infection emerged primarily in the peripheral tissues, like in the kidneys or the nerve tissue. "A heritability of this organ specificity in the reaction to tuberculous infection," Fischer announced in his 1940/41 annual report, was "thus proven experimentally for the first time." ${ }^{220}$ In the next annual report Fischer added that the results of the rabbit experiments could be "conferred without further ado [...] to humans. This also yields important prospects for combatting tuberculosis in humans." According to Fischer, at the tuberculosis congress in Baden-Baden Diehl "held a lecture that aroused great attention and was received with much applause." 221 From 1940 on Fischer and Diehl presented the results of the rabbit experiments in Sommerfeld to the experts. ${ }^{222}$

The two different manifestations of tuberculosis could be bred constantly and in a pure form through eight generations of rabbits. The hereditary character of the clinical picture remained completely preserved, "even when animals were pre-treated with human tuberculosis bacilla, which are avirulent for rabbits." 223 Now Diehl attempted to get to the bottom of the riddle of organ resistance in animal experiments:

It was attempted to modify the type of tuberculosis manifestation by inbreeding specimens.

For this ink blocking, re-infections and organ transplants were performed. The persistence

\footnotetext{
${ }^{218}$ Twin research was not abandoned altogether, however. In his report to the Reich Research Council of September 1943, Verschuer wrote: "The research on the tuberculous twins are being continued through the collection of futher material and catamnestic analysis of the pairs of twins studied so far." Verschuer, Bericht über das Projekt “Tuberkulose," n.d. [September 1943], BArch. Koblenz, R 73/15.342, p. 54.

${ }^{219}$ Verschuer to Diehl, 29/6/1935, MPG Archive, Dept. III, Rep. 86 A (Münster), No. 7.

${ }^{220}$ Fischer, Tätigkeitsbericht 1940/41, MPG Archive, Dept. I, Rep. 3, No. 18.

${ }^{221}$ Fischer, Tätigkeitsbericht 1941/42, MPG Archive, Dept. I, Rep. 3, No. 19.

${ }^{222}$ Fischer/Diehl, Experimente; Diehl, Tierexperimentelle Erbforschung; idem., Erbe.

${ }^{223}$ Verschuer, Wirkung von Genen, p. 385.
} 
of the way in which tuberculosis is manifested appears to be very great in the bred specimens. These experiments will be expanded further, since it is possible that their result can be of fundamental importance for the medical therapy of humans. The endeavors to obtain clarity about the status of individual organs in the process of infection in the bred specimens aimed in the same direction. What was particularly interesting here was the status of the liver. ${ }^{224}$

In addition to these experiments, Diehl began crossing the two pure breeds with each other. When in the period from April to July $1943^{225}$ he set about infecting the animals proceeding from the crossbreeding experiments with tuberculosis, he believed that his research was entering a decisive phase:

\begin{abstract}
Crossing the two pure breeds has now yielded a large F 1 . Seventeen animals from the pure breeding experiments were taken as the point of departure. The F 1 amounts to around 50 animals. From the F 2, which we generated from animals born the previous year, we unfortunately lost quite a few because of the wet weather and the consequently wet feed. Now we have only about 40 animals. In the coming year the F2 will then appear in full force. I am glad that these animals were "vaccinated away"without having been able to reproduce. Only the desired "immune" animals will reproduce. I believe that if I aim for an F2 of about 300 animals that should be sufficient. ${ }^{226}$
\end{abstract}

The approach was clear: Through crossing the two pure breeds Diehl hoped to be able to cultivate "tuberculosis-resistant" rabbits. Thus, he continued working as if obsessed, although he felt miserable and exhausted at the time, since the late consequences of a lung tuberculosis contracted in his youth became noticeable. Diehl and Verschuer were feeling time pressure, too, not least because they had heard about rabbit experiments by the American tuberculosis researcher Max Bernhard Lurie (* 1893). In January 1943 - the catastrophe of Stalingrad was imminent Diehl was still filled with hope by the sight of the dying rabbits:

I go into the stalls in Sonnenberg often. Biological events are taking place there with a cruel consequence. It seems obvious that I hold the key in my hand. The decision will be made this summer! $!^{227}$

The hope for tuberculosis-resistant rabbits was not fulfilled, however. Nevertheless, Diehl continued working doggedly on crossing the two pure breeds until the end of the Third Reich. In October 1944 he had dissected nearly 700 rabbits originating from

\footnotetext{
${ }^{224}$ Verschuer, Tätigkeitsbericht 1943/44, MPG Archive, Dept. I, Rep. 3, No. 22. In Diehl's draft the final point was explained in more detail: "In order to obtain clear results, pieces of the liver were surgically removed from members of the last two inbred generations, these pieces tested in terms of their antibacterial power and the animals, after recovering from surgery, tested as usual. The antibacterial power of the liver proved to be very different among the animals. The lung is currently being examined in the same direction." Diehl's draft for the Tätigkeitsbericht 1943/44, ibid. Similarly: Bericht über das Projekt "Tuberkulose," n.d. [March 1944], BArch. Koblenz, R 73/15.342, pp. 65-65 v.

${ }^{225}$ Diehl's draft for the Tätigkeitsbericht 1943/44, MPG Archive, Dept. I, Rep. 3, No. 22; Bericht über das Projekt “Tuberkulose," n.d. [March 1944], BArch. Koblenz, R 73/15.342, pp. 65-65 v. ${ }^{226}$ Diehl to Fischer, 10/8/1942, MPG Archive, Dept. III, Rep. 86 A (Münster), No. 7. Cf. also Fischer, Tätigkeitsbericht 1942/43, MPG Archive, Dept. I, Rep. 3, No. 20.

${ }^{227}$ Diehl to Verschuer, 23/1/1943, MPG Archive, Dept. III, Rep. 86 A (Münster), No. 7.
} 
these crosses and performed statistical analyses of the results - but without attaining any final certainty. Nonetheless, Diehl - and Verschuer as well - still believed that this was the way to achieving a breakthrough in tuberculosis research. ${ }^{228}$

Biochemists were also interested in Diehl's experiments. The specifically genetic resistance of the organs had to be effected through the production of a substance in the organism, which prevented or hindered the tuberculosis bacillus from settling in certain organs. Thus the search was on for a biochemical compound. If they succeeded in isolating and identifying it, this would yield far-reaching consequences for tuberculosis therapy as well. This is the background of the lateral contacts between the external office of the KWI-A in Beetz and the KWI for Biochemistry under Adolf Butenandt. The connections extended all the way back to 1942. To keep from distorting the results of his study, Diehl required for his injections an emulsion that was completely dispersed, i.e. the tuberculosis bacilla had to be distributed as regularly as possible without any clumping. To solve this problem, Diehl had arranged with Gerhard Schramm $\left({ }^{*} 1910\right)$ of the KWI for Biochemistry to use the colloid mill located there, which could liquidify the tissue by rotating it at high speeds, in late August or early September 1942. ${ }^{229}$ Verschuer made Adolf Butenandt himself aware of Diehl's experiments in July 1944, who proved to be "extraordinarily" interested. "Unfortunately," Verschuer reported to his friend Diehl, "we were interrupted, so that our conversation did not come to a conclusion. Thus I cannot give you any result yet today. Yet I will come back to the matter upon the next opportunity." ${ }^{230}$ In a telephone conversation just a few days later, Butenandt expressed his wish to meet Diehl personally as soon as possible and learn about his experiments. Verschuer asked Diehl to bring "some of his family tables, tables, pictures or specimens." 231 The meeting was supposed to take place in July or August, but apparently was delayed until October. ${ }^{232}$ This is in keeping with the comment in a report by Verschuer to the DFG of September 1944, that contact had been established with Butenandt in connection with the tuberculosis project in order to accomplish the biochemical analysis. ${ }^{233}$ The collaboration between Diehl and Butenandt survived the Third Reich, but Diehl's research ultimately fizzled out. ${ }^{234}$

\footnotetext{
${ }^{228}$ In October 1944 they expressed themselves optimistically to the Reich Research Council - and not entirely truthfully - that "the heredity can already be surveyed" in the hybrids. Bericht über das Projekt "Tuberkulose," n.d. [October 1944], BArch. Koblenz, R 73/15.342, p. 48.

${ }^{229}$ Diehl to Fischer, 10/8/1942, MPG Archive, Dept. III, Rep. 86 A (Münster), Nr. 7.

230 Verschuer to Diehl, 17/7/1944, ibid.

${ }^{231}$ Verschuer to Diehl, 20/7/1944, ibid.

${ }^{232}$ Verschuer to Butenandt, 30/9/1944, MPG Archive, Dept. III, Rep. 84/2, wiss. Korrespondenz. Verschuer's report to the Reich Research Council of October 1944 reads: "For the continuation of these studies using biochemical methods contact with Professor Butenandt has been established." Bericht über das Projekt “Tuberkulose,” n.d. [October 1944], BArch. Koblenz, R 73/15.342, p. 48.

${ }^{233}$ Verschuer to DFG, Kennwort: Tuberculosis (Bericht für den Zeitraum vom 1. April bis zum 30. September 1944), 4/10/1944, ibid., p. 48.

${ }^{234}$ On this: Trunk, Zweihundert Blutproben, p. 47.
} 
Through Diehl's rabbit experiments, Butenandt became aware of the entire range of genetic pathological research performed under the banner of phenogenetics at the KWI-A. On November 16, 1944 Verschuer held a lecture to the Prussian Academy of Sciences about "Heredity in Infectious Diseases," 235 in which he attempted to link the results of the phenogenetically oriented research - especially Diehl's rabbit experiments - with the work by Alfred Kühn and Adolf Butenandt on gene action chains. It was no longer possible to publish the text of the lecture before the imminent collapse of the Third Reich, but it appeared - unaltered, as far as we can judge - in 1948 under the title Die Wirkung von Genen und Parasiten im Körper des Menschen ("The Effect of Genes and Parasites in the Human Body"). Verschuer's argumentation is still entirely fixed upon the problem of the interaction between infection and hereditary disposition, but also picked up on some thoughts of Butenandt's to touch on issues that are highly relevant today. For instance, Verschuer emphasized the importance of infectious diseases that jump from animals to humans, which is nothing short of prophetic in the age of BSE and SARS. He further indicated the similarity between viruses and genes - today we know that a significant part of the human genome consists of incorporated viral material. In Butenandt Verschuer found an attentive listener; the two even had "an especially pleasant (post-)meeting over a cup of tea at home." ${ }^{236}$

\subsubsection{Experimental Genetic Pathology}

On January 1, 1941 the Department for Experimental Genetic Pathology under the direction of Hans Nachtsheim began its work. In the meeting of the Board of Trustees on January 8, Fischer explained - presumably above all for Leonardo Conti - the key role of the new department. In the science of genetics, Fischer claimed, "the animal experiment [had] always been in the lead"; "human genetic research" had "always [received] directions and stimulation from the former." Nachtsheim's great service had been "to have recognized the fundamental importance of this wonderful research material and to have set about its evaluation [...]. This new ground he has broken must become ours." 237 This ground was not entirely new, as since the institute's founding in 1927 Fischer had occasionally provided for experiments to be performed on rats, rabbits or guinea pigs in order to get to the bottom of the genetics of normal attributes, especially race attributes, through the

\footnotetext{
${ }^{235}$ Verschuer to de Rudder, 4/10/1944, MPG Archive, Dept. III, Rep. 86 A (Münster), No. 8.

${ }^{236}$ Verschuer to de Rudder, 20/11/1944, ibid. Similarly, Verschuer to Fischer, 20/11/1944, MPG Archive, Dept. III, Rep. 86 A (Münster), No. 9: "I am pleased to have at least him [Butenandt] here from time to time. Otherwise things have become very quiet scientifically."

${ }^{237}$ Anlage 2 zur Niederschrift über die Sitzung des Kuratoriums des KWI-A am 9/1/1941: Bericht über die Neueinrichtung einer Abteilung für experimentelle Erbpathologie, erstattet vom Direktor, MPG Archive, Dept. I, Rep. 1 A, No. 2400, pp. 187-193, quotes: fol. 190 (original emphasis).
} 
study of embryos. ${ }^{238}$ But now Nachtsheim's preliminary works opened up the possibility of continuing this research on a grand scale and, what was even more important, expanding it to the area of genetic pathology. Although Nachtsheim's papers since 1941 fit into the leading research paradigm of phenogenetics and were not designed for rapid and direct application to race hygiene, Fischer never tired of emphasizing the practical importance of experimental genetic pathology before the board and also to the DFG, to whom he applied for 40,000 RM in research funds for Nachtsheim's department on March 13, 1941:

What is most important is the corresponding examination of those genetic diseases that are important for humans. These are then model experiments for human genetic pathology. They will teach us why the same genetic condition often occurs in such different intensities; it will give us tips as to whether the development can be steered by external influences.

At the same time, Fischer stressed again that there was no alternative to the animal model:

Such studies are practically impossible on humans, because it is never possible to know with any certainty what would have become of a dead embryo.

As Fischer elaborated to the German Research Association, Nachtsheim and his staff were to perform three parallel series of experiments on the diseases and anomalies to be studied: The first were breeding experiments. Nachtsheim's group of scientists was to detect rabbits with pathological genes, to propagate these "in pathologically pure culture" to the extent that pregnant females could be killed at all stages of embryonic development, and finally the heredity of the pathological genes be elucidated in crossbreeding experiments. Second, the dead embryos - in close collaboration with the Department for Embryology, still to be founded - were to be examined pathologically and histologically, in order to be able to study the inception of pathological processes during ontogenesis by comparing findings from various embryonic stages. Third and finally, it was to be attempted to influence the outbreak of disease by environmental stimuli (poisons, chemicals, feeding), not least in order to be able to differentiate between a "general" and a "genetically increased" susceptibility, which, according to Fischer, was "of particular importance in view of the most modern methods of treating diseased humans." At the close of his application Fischer stated his conviction "that these theoretical and experimental studies will be of benefit to suffering humanity and serve the preservation of the genetic health of our Volk." Mentioning discreetly that the Reichsgesundheitsführer shared his views, Fischer guaranteed that he could "carry the full responsibility" for the importance of Nachtsheim's research "even now at a time of war."

\footnotetext{
${ }^{238}$ Fischer referred to this in his application to the DFG of $13 / 3 / 1941$, BArch. Koblenz, R 73/11.004. Among the works mentioned at this juncture Fischer were Kim's paper on embryonic pig skulls and Hauschild's on embryonic "negro skulls." All subsequent quotes also come from this application.
} 
When Nachtsheim started in Dahlem, he had at his disposition, as Fischer informed the DFG, a series of rabbit strains that exhibited genetic diseases or disabilities: These were "genetic epilepsy [...], shaking palsies and other nervous diseases; glaucoma and other eye diseases; deformation of the limbs, the external sex organs (similar to those of humans), harelip and cleft palate and many others." 239

From Nachtsheim's report to the German Research Association of January 14, 1941 - the first he submitted from his new position in Dahlem - proceed the work emphases of the group of scientists around Nachtsheim in 1940, that is, still at the Institute for Genetics and Breeding Research. At the very foreground was epilepsy research. Nachtsheim had bred from Vienna White rabbits a pure "strain of epileptics" and shown "through crossing with strains free of epilepsy [...] that one recessive gene [was] responsible for the increased convulsion-readiness." However, this gene was subject to certain fluctuations in manifestation: "In the pure-bred epileptic strain the condition becomes manifest in about $70 \%$ of individuals." ${ }^{240}$ Nachtsheim had also made some progress in the search for a genetic marker, although no real breakthrough had been achieved. According to Nachtsheim's observations, the gene responsible for the increased convulsion-readiness must also grant leucism (the white color of the coat), although Nachtsheim was forced to admit that not every form of leucism could be traced back to this gene. Moreover, the influence of other genes, such as those for albinoism or "sooty coloring," could suppress the occurrence of leucism. The breeding experiments were complemented by a largescale series of experiments on nearly 600 rabbits of different races, both from the "epileptic" and the "non-epilectic" lines, in which an injection of cardiazol induced convulsions to test their convulsion readiness.

In addition to epilepsy research, pathogenetic research on eye diseases, especially on the progressive heredity of certain forms of cataracts, constituted a second working emphasis, in collaboration with Hellmuth Gürich of the Charité Ophthamalogical Clinic. A third and final emphasis emerged from the work of the two doctoral students Christian Schnecke ( $\left.{ }^{*} 1917\right)$ and Harry Suchalla (1912-1985), who concerned themselves with growth anomalies. Schnecke's studies on the "lethal dwarfism in rabbits led to the result, also important for the assessment of corresponding conditions in humans, that while the recessive dwarf factor in general may lead to a pathological form only in the homozygotes, but that there are genes that are harmless in and of themselves, which, when linked with the dwarf

\footnotetext{
${ }^{239}$ In his report to the Board (MPG Archive, Dept. I, Rep. 1 A, Nr. 2400, p. 190) Fischer further mentioned rabbits "with a kind of St. Vitus' dance." "Genetic St. Vitus' Dance," one of the indications in the GzVeN, was the contemporary term for Huntington Chorea. It is unclear whether this might have indicated the rabbits with "shaking palsy," which is a general lay term for Morbus Parkinson. In his activity report for the 1940/41 fiscal year Fischer also mentioned rabbits with "skin diseases" (Fischer, Tätigkeitsbericht 1940/41, MPG Archive, Dept. I, Rep. 3, No. 18).

${ }^{240}$ Nachtsheim, Bericht über die im Jahre 1940 mit Unterstützung des Reichsforschungsrates durchgeführten Untersuchungen zur vergleichenden Erbpathologie, 14/1/1941, p. 1, BArch. Koblenz, R 73/13.328 (original emphasis). For the basics on Nachtsheim's epilepsy research: Schwerin, Experimentalisierung, pp. 282-288.
} 
factor in the homozygous form, yield a combination with lethal effects, even if the dwarf factor is only present in a single dose." Suchalla crossed giant and dwarf varieties of rabbits. This paper, Nachtsheim emphasized, represented "the first attempt to achieve an analysis of skull genetics by performing experiments with modern methods on large amounts of material." ${ }^{241}$ Here the research projects of the Department for Experimental Genetic Pathology overlapped with Hans Grebe's studies on chondrodysplasia - Nachtsheim and Grebe did, in fact, work together closely, for instance, on a genetic biology dictionary. ${ }^{242}$

In 1941, the first year for the Department for Experimental Genetic Pathology, the group around Nachtsheim was able to continue its research only on a very restricted scale. Because it was increasingly difficult to obtain feed for the experimental animals, it was necessary to reduce their number and restrict the "consumptive research." The apparatus applied for arrived only after major delays - as, for instance, the "convulsator" for the generation of electric spasms - or were not delivered at all, as was the case for a slit lamp, a Zeiss microscope and a binocular eyepiece. The greatest problem was that all of the staff was called up for military service, such that the experiments could only be continued by Nachtsheim on his own. The fact that epilepsy research remained at the focus, although it had come to a preliminary conclusion in 1940, was grounded first of all in pragmatic reasons: The research on eye diseases could not be continued because Hellmuth Gürich, the partner in this collaboration at the ophthamalogical clinic, was drafted to the Wehrmacht. The same was true for research projects on growth anomalies. By this time Christian Schnecke and Harry Suchalla had also been drafted. The planned genetic pathological studies on a syndrome observed in dachhunds (characterized by hypodactyly or hyperdactyly, respectively, and hereditary blindness) never really got in gear. The resumption of research on the "Pelger anomaly" (today: Pelger-Huët nuclear anomaly), an autosomal-dominant hereditary anomaly of the leucocytes that occurs in both humans and rabbits, was just getting started - the first task that kept Nachtsheim busy was breeding a "pure Pelger-Huët strain," ${ }^{243}$ on the basis of which the characteristics of the gene it was based on could be studied.

When an epidemic broke out among the laboratory rabbits in summer of 1942 , which necessitated halting the epilepsy experiments temporarily, the research on the Pelger anomaly shifted far into the foreground. Moreover, in this area Nachtsheim was able to present a sensational finding. While up until that time it had been assumed that "this deviation of the blood count from the normal [was] to be observed in both humans and animals as a harmless variety of blood without any further clinical manifestations," Nachtsheim produced evidence that in a rabbit

\footnotetext{
${ }^{241}$ Ibid., p. 5. Cf. Schnecke, Zwergwuchs; Suchalla, Variabilität.

${ }^{242}$ Schwerin, Experimentalisierung, pp. $278 \mathrm{f}$.

${ }^{243}$ Nachtsheim, Bericht über die im Jahre 1941 mit Unterstützung des Reichsforschungsrates durchgeführten Untersuchungen zur vergleichenden und experimentellen Erbpathologie, 27/3/1942, here: pp. 1, 5-7, BArch. Koblenz, R 73/13.328. Cf. Schwerin, Experimentalisierung, pp. 263-268.
} 
which inherited the Pelger gene from the maternal and paternal side, and was thus homozygous with reference to the Pelger gene, "most serious impairments" 244 were to be expected. According to Nachtsheim's observations, most of the homozygous Pelger rabbits died in the womb. The few survivors - the "über-Pelger," as Nachtsheim called them - showed not only a changed blood count, but also a whole bundle of other clinical symptoms: "meager growth, serious deformation of the limbs, especially the forelegs, with shortening and twisting of the long, hollow bones and synostoses [fusion of bones], rashes of scurf around the muzzle and nose, salivation, anorexia." 245

These findings, Nachtsheim explained, were of extraordinary importance for humans. True, no human "homozygous Pelgers" had been encountered as yet. Yet, trusting in the soundness of the animal model, Nachtsheim predicted that in humans, too, the homozygous carriers of the Pelger gene, if they were able to survive at all, would "thus certainly be greatly weakened in their vitality and deformed." In any case it is clear that the Pelger anomaly did not constitute a "harmless "play of nature" " in humans either, but was an "erroneous mutation [...], whose propagation, in terms of race hygiene, [was] altogether undesirable." Here Nachtsheim opened up a new race hygiene perspective. The only way to be able to follow this perspective was to link the research on animal models with the genetic pathology of humans. The mission of the research would be, in Nachtsheim's words, "to carry out exhaustive surveys about the propagation of the Pelger gene in human populations." At the same time it would have to be investigated "whether among the stillbirths or behind an already familiar clinical picture, especially among cases with certain deformations of the limbs, homozygous Pelgers are to be found."246 This suggested building a bridge from experimental genetic pathology to the genetic pathological research by Heinrich Schade and Hans Grebe, namely to Grebe's series of studies on stillbirths. In his report about the 1943 fiscal year Nachtsheim remarked that work in this direction had been "initiated," but had "not yet led to positive results." He further announced embryological studies in order to clarify in "which embryonic stage the homozygous Pelgers die and what the cause of this death" and "what, on the other hand, [is] the cause of the survival of individual homozygous Pelgers of certain parents." ${ }^{247}$ The clinical and histopathological diagnostic

\footnotetext{
${ }^{244}$ Nachtsheim, Bericht über die im Jahre 1942 mit Unterstützung des Reichsforschungsrates durchgeführten Untersuchungen zur vergleichenden und experimentellen Erbpathologie, 22/3/1943, BArch. Koblenz, R 73/15.342, pp. 99-112 (no continuous pagination), quote: p. 100.

${ }^{245}$ Nachtsheim, Bericht über die im Jahre 1943 im Auftrage des Reichsforschungsrates durchgeführten Untersuchungen zur vergleichenden und experimentellen Erbpathologie, 15/3/1944, ibid., pp. 79-84, quote: p. 82 .

${ }^{246}$ Nachtsheim, Bericht über die im Jahre 1942 mit Unterstützung des Reichsforschungsrates durchgeführten Untersuchungen zur vergleichenden und experimentellen Erbpathologie, 22/3/1943, ibid., pp. 99-112 (no continuous pagination), quotes: p. 100.

${ }^{247}$ Nachtsheim, Bericht über die im Jahre 1943 im Auftrage des Reichsforschungsrates durchgeführten Untersuchungen zur vergleichenden und experimentellen Erbpathologie, 15/3/1944, ibid., pp. 79-84, quote: p. 82. Cf. Nachtsheim, Pelger-Anomalie I und II.
} 
picture of the homozygous Pelgers also demanded closer study. Since these formulations were repeated word for word in Nachtsheim's final report, which was dated March 15, 1944, it must be assumed that the studies never picked up speed.

In 1942 Nachtsheim turned his attention to another hereditary blood anomaly of the rabbit, which had its parallel in humans: Erythroblastosis, which occurs in rabbits as hereditary, general dropsy (Hydrops universalis congenitus). Today we know that this form of newborn jaundice in cases of incompatible rhesus factors in the blood of mother and child is caused by the formation of antibodies in the mother and their transition into the circulatory system of the fetus, where they destroy red blood cells. In 1942, however, Nachtsheim traced erythroblastosis in rabbits back to a gene that was "inherited recessively." But, Nachtsheim continued, this was "not a case of simple heredity" - indeed, it appears "that a wide variety of factors besides the remaining genotype, also those of a peristatic nature - had an influence on the manifestation of the condition." ${ }^{248}$ In 1943 Nachtsheim presumed that "several genes" were involved. Perhaps there must also be "a certain conditional factor present [...] so that the actual dropsy gene [could] become effective." Possibly, however - and Nachtsheim was on the right track here - "in addition still other factors located in the mother but outside the embryo [played] a role." As far as erythroblastosis in humans was concerned, Nachtsheim's judgement in 1943 was more cautious, stating that it was "still quite contested," whether a hereditary condition was involved or not - much spoke against, some for heredity. ${ }^{249} \mathrm{In}$ his penultimate report of March 15, 1944 Nachtsheim suggested that "certain observations on humans [made] probable a connection between the fetal blood diseases and certain serum characteristics of the blood." Thus it appeared desirable "to test experimentally for existing connections of this kind in animals, too." Again, he states that experiments in this direction had been "initiated." ${ }^{250}$ By the way, the serological studies on Hydrops universalis congenitus in rabbits were conducted in collaboration with the Serological Department of the Reich Health Office, and the histopathological studies by Hans Klein (1912-1984). Klein was Senior Physician in the Pathological Department of the Rudolf Virchow Hospital in Berlin under Berthold Ostertag (1895-1975), who, however, was dispatched along with part of the Pathological Institute to the SS Sanatorium Hohenlychen at the time. ${ }^{251}$

\footnotetext{
${ }^{248}$ Nachtsheim, Bericht über die im Jahre 1942 mit Unterstützung des Reichsforschungsrates durchgeführten Untersuchungen zur vergleichenden und experimentellen Erbpathologie, 22/371943, ibid., pp. 99-112 (no continuous pagination), quotes: p. 111.

${ }^{249}$ Nachtsheim, Bericht über die im Jahre 1943 im Auftrage des Reichsforschungsrates durchgeführten Untersuchungen zur vergleichenden und experimentellen Erbpathologie, 15/3/1944, ibid., pp. 79-84, quote: p. 83.

${ }^{250}$ Nachtsheim, Bericht über die im Halbjahr 1943/44 im Auftrage des Reichsforschungsrates durchgeführten Untersuchungen zur vergleichenden und experimentellen Erbpathologie, 15/3/1944, ibid., pp. 61-63, quotes: p. 63.

${ }^{251}$ Verschuer, Tätigkeitsbericht 1943/44, MPG Archive, Dept. I, Rep. 3, No. 22; Nachtsheim, Bericht über die im Halbjahr 1943/44 im Auftrage des Reichsforschungsrates durchgeführten Untersuchungen zur vergleichenden und experimentellen Erbpathologie, 15/3/1944, BArch. Koblenz, R 73/15.342, pp. 61-63, here:p. 63; idem., Bericht über die im Halbjahr 1944 im Auftrage des
} 
While the research on fetal blood diseases of the rabbit was an emphasis of the work in the Department for Experimental Genetic Pathology in 1942, in 1943 the research on the growth anomalies of the rabbit swung into full gear, when Wouter Ströer, the designated director of the planned Department for Embryology, took on the histological study of the rabbits with "lethal dwarfism" during his residency in Dahlem. ${ }^{252}$

In addition to these working areas, in the final 2 years of the war, epilepsy research moved back up to the top of the agenda of the Department for Experimental Genetic Pathology. In further breeding experiments Nachtsheim investigated the heredity of genuine epilepsy. Here it had become apparent, he reported in 1944, that the "epilepsy gene," although its behavior was "generally recessive," and thus had to be inherited homozygously in order to take effect, was also able "to let the diagnostic picture of epilepsy develop" even in cases of heterozygous heredity, "in combination with certain genes." As such, "the carrier of two albino genes and one epilepsy gene can become an epileptic." The situation was similar for the allele closest to the albino gene, the "black factor." 253 In addition to his breeding experiments, from 1943 Nachtsheim performed a great number of experiments on producing spasms through oxygen deprivation. Since these experiments led him directly into the research accompanying the Nazi "euthanasia" program, they are described in detail in another section.

\subsubsection{The Genetics of Normal Attributes}

This field of research now lagged behind, also and primarily because of problems acquiring material. Much of genetic pathology research was based on clinical material, which Verschuer and his staff had brought with them from Frankfurt, and which could be supplemented continuously through individual cases brought to the institute for evaluation. The genetic pathology research by Diehl and Nachtsheim also used the animal model - and the rabbit stocks were safeguarded by the elevation

Reichsforschungsrates durchgeführten Untersuchungen zur vergleichenden und experimentellen Erbpathologie, 15/3/1944, ibid., pp. 42-43, here: p. 63. The publication of the results took place in 1947 (Nachtsheim/Klein, Hydrops congenitus universalis). Nachtsheim also collaborated with Hans Klein in his research on the Pelger gene (cf. Klein, Pelger-Anomalie). - Ostertag and Klein performed autopsies of children from the Wittenau Sanatoriums murdered as part of the Nazi "euthanasia" program. In early 1945, Klein also studied the lymph nodes from the armpits of twenty Jewish children upon whom Kurt Heißmeyer (1905-1967), senior physician at the SS Sanatorium Hohenlychen, performed criminal human experiments for tuberculosis research in the period from December 1944 to April 1945 at the Neuengamme concentration camp near Hamburg. For details on these indirect connections: Weindling, Genetik und Menschenversuche.

${ }^{252}$ Verschuer, Tätigkeitsbericht 1943/44, MPG Archive, Dept. I, Rep. 3, No. 22.

${ }^{253}$ Nachtsheim, Bericht über die im Halbjahr 1943/44 im Auftrage des Reichsforschungsrates durchgeführten Untersuchungen zur vergleichenden und experimentellen Erbpathologie, 15/3/1944, BArch. Koblenz, R 73/15.342, pp. 61-63, quotes: p. 61. 
of the KWI-A's status into that of a military economic enterprise. General human genetic research, in contrast, was based essentially on the combination of twin and family research. Yet these methodological approaches were nearly completely obstructed in the second phase of the war. As Fritz Lenz lamented in his annual report for the "Institute for Race Hygiene" in 1943/44:

The work of research has been quite impeded by the circumstances of the war, especially since summer 1943. It is very difficult and frequently impossible to acquire sufficient observation material for certain essential scientific and practical problems. As a consequence of the evacuation of women and children, family research and twin studies are practically impossible. Not even surveys can be conducted any more. ${ }^{254}$

Conventional twin research in this area apparently did not come to complete standstill, ${ }^{255}$ but the difficulty in acquiring subjects for both twin research and family research soon became an obstacle that could hardly be surmounted. Thus it is no coincidence that the research in the area of the genetics of normal attributes in the year 1943 was restricted to two projects - "Specific Proteins" and "Eye Color" which made use of the unfettered access to subjects in the Auschwitz concentration and extermination camp - more on this later.

\subsubsection{Genetic Psychology}

In the Department for Genetic Psychology, Gottschaldt, who was called up to the Wehrmacht for a time, and his staff continued even after the start of World War II with the evaluation of the enormous amount of material they had compiled in the twin camps in 1936/37, and working through it "in a new methdological way." Preliminary results were published in 1942 in the first issue of Erbpsychologie, a new series of publications edited by Eugen Fischer and Kurt Gottschaldt. Through this work genetic psychology received a new foundation.." 556 Analysis continued in the final war years, accelerated after the Department for Genetic Psychology was

\footnotetext{
${ }^{254}$ Lenz, Tätigkeitsbericht 1943/44, 28/3/1944, MPG Archive, Dept. I, Rep. 3, No. 21. Quite similarly, Verschuer: "The twin and family research projects in progress continue to be extremely restricted by the war conditions." Verschuer, Tätigkeitsbericht 1943/44, MPG Archive, Dept. I, Rep. 3, No. 22. Cf. Verschuer, Bericht über das Forschungsprojekt "Rassenhygiene," n.d. [September 1943], BArch. Koblenz, R 73/15.342, p. 56.

${ }^{255}$ Thus the Portuguese guest scholar José Ayres de Azevedo investigated "the quantitative course of blood-group reactions for a large amount of material from identical and fraternal twins," establishing "that in this regard, too, a clear hereditary conditionality is demonstrated" (Verschuer, Tätigkeitsbericht 1942/43, MPG Archive, Dept. I, Rep. 3, No. 20). Cf. on this Müller-Hill, Blut, p. 196. - "A paper initiated and advised by Lenz about the body length and weight of identical twins in comparison with fraternal twins, which yielded that identical twins are somewhat shorter and lighter on average than fraternal twins, was published by its Hungarian author Dr. L.[adislaus] Apor, unfortunately only in the Magyar language." (Lenz, Tätigkeitsbericht 1943/44, 28/3/1944, MPG Archive, Dept. I, Rep. 3, No. 21).

${ }^{256}$ Verschuer, Tätigkeitsbericht 1942/43, MPG Archive, Dept. I, Rep. 3, No. 20.
} 
removed to Stavenhagen castle in Mecklenburg in September 1943. ${ }^{257}$ These tasks of evaluation were extremely elaborate: In the 6 months from October 1943 to March 1944, Gottschaldt reported, "around 25 psychological analyses [were dictated], each of which was 200 pages long." ${ }^{258}$ By October 1944 Gottschaldt and his staff had put to paper around 65 psychological analyses, "which cover extraordinarily comprehensive material, prepared for statistical evaluation, of more than 120,000 individual findings." ${ }^{259}$ And for the coming 6 months Gottschaldt requested another 10,000 sheets of writing paper.

During the war period, Gottschaldt could not simply retire to his ivory tower. More and more he worked together with state and party offices, and endeavored to make the methods of genetic psychology useful for genetic health, race and colonial policy - be it voluntarily or under the pressure of the conditions must remain an open question. Even today, almost nothing is known about most of these projects. In the 1941/42 fiscal year, Gottschaldt's department, in collaboration with the Department for the Protection of Children and Youth (Kinder- und Jugendschutz) of the NSV, began with "catamnestic surveys of children formerly under the care of state welfare." 260 The 1942/43 business report also stated that the "Polyclinic for Nervous and Difficult Children," whose resources "increasingly [were] claimed for the scientific evaluation of the very extensive material on families that accumulates there," 261 and that this would continue. From 1941/42 Gottschaldt held lectures and training courses, connected with the German Labor Front (Deutsche Arbeitsfront), the Department for Professional Training and the Improvement of Efficiency (Abteilung für Berufsausbildung und Leistungsertüchtigung) in the Reich Chamber of Commerce and the Colonial Policy Office of the NSDAP. ${ }^{262}$ A deeper collaboration arose from the contact with the Colonial Policy Office - more on this later.

With the excursion into colonial science, Gottschaldt set out on the field of race psychology, which he had only skirted before World War II. Thus it was fitting that he prepared an article about "Race Psychology" for the fifth edition of "BaurFischer-Lenz."263 Also to be viewed in this context are the Untersuchungen über

\footnotetext{
${ }^{257}$ Verschuer to Fischer, 20/9/1943, MPG Archive, Dept. III, Rep. 86 A (Münster), No. 9. The castle belonged to an acquaintance of Gottschaldt's. Fischer managed to wrangle an "allocation" with the assistance of the Gauleiter (District Leader) of Mecklenburg, Friedrich Hildebrandt (1898-1948). Cf. Gottschaldt, Bericht über das Forschungsprojekt “Zwillingslager," 25/9/1943, BArch. Koblenz, R 73/15.342, p. 70.

${ }^{258}$ Gottschaldt, Bericht über das Forschungsprojekt “Zwillingslager," 14/3/1944, p. 66.

${ }^{259}$ Gottschaldt, Bericht über das Forschungsprojekt “Zwillingslager," 4/10/1944, p. 49.

${ }^{260}$ Fischer, Tätigkeitsbericht 1941/42, MPG Archive, Dept. I, Rep. 3, No. 19. These studies were continued well into the final years of the war. Cf. Verschuer, Tätigkeitsbericht 1942/43 and 1943/44, respectively, MPG Archive, Dept. I, Rep. 3, No. 20 and No. 22, respectively.

${ }^{261}$ Verschuer, Tätigkeitsbericht 1942/43, MPG Archive, Dept. I, Rep. 3, No. 20.

${ }^{262}$ Fischer, Tätigkeitsbericht 1941/42, MPG Archive, Dept. I, Rep. 3, No. 19; Verschuer, Tätigkeitsbericht 1942/43 and 1943/44, respectively, MPG Archive, Dept. I, Rep. 3, No. 20 and No. 22, respectively.

${ }^{263}$ Gottschaldt's catchwords for the 1942/43 Jahresbericht, MPG Archive, Dept. I, Rep. 3, No. 20. An article about "genetic psychology" was also planned. Cf. Fangerau, Etablierung, pp. 60-62.
} 
den Rassenruf mongolider Völker im Rassenbewußtsein von Japanern ("Studies about the Race Reputation of Mongoloid Nations in the Race Consciousness of Japanese"), which were carried out in the Department for Genetic Psychology in collaboration with the Cultural Department of the Japanese Embassy - presumably by the two Japanese guest scholars, the doctoral student Masataka Takagi and Professor Masaji Kamitake. The fact that Gottschaldt participated in a "GermanJapanese Science Camp" together with the two guest scholars in summer 1942 suggests that he, too, was actively involved in these obscure studies. Finally, it must be added that a doctoral student of Gottschaldt's, Inez de Beauclair (1897-1981), carried out "Examinations of Physical Constitution on Southern and Northern Chinese" in Japanese-occupied China during World War II. ${ }^{264}$

\subsection{The Kaiser Wilhelm Institute for Anthropology, Human Heredity and Eugenics and the State Crimes of the Nazi Regime, 1939-1945}

\subsubsection{Fischer, Verschuer, and the NSDAP}

Since mid-1938 deliberations had been in progress about admitting Eugen Fischer and Fritz Lenz ${ }^{265}$ to the NSDAP. It can be presumed that Fischer's political allies, Arthur Gütt and Walter Groß, exerted pressure on Fischer and his institute to this end once the NSDAP lifted its ban on admitting new members in $1937^{266}$ - in any case at least ten members of the KWI-A staff joined the party on May 1, 1937. ${ }^{267}$ That Fischer yielded to the pressure of his political patron and made active efforts to join the party from mid-1938 on was probably also a matter of calculation, and

\footnotetext{
${ }^{264}$ Fischer, Tätigkeitsbericht 1941/42, MPG Archive, Dept. I, Rep. 3, No. 19; Gottschaldt's catchwords for the 1942/43 Jahresbericht, MPG Archive, Dept. I, Rep. 3, No. 20. After 1945 de Beauclair lived in Taiwan. She published a series of ethnological works on China and the South Pacific.

${ }^{265}$ It is not entirely clear when Lenz joined the NSDAP. Klee, Personenlexikon, p. 367, names May 1, 1937 as his date of admission and adds that Lenz was also a member of the NSDÄB and the NSDozentenbund. Rissom, Fritz Lenz, p. 24, in contrast, cites a postwar deposition by Lenz, which states that he had become a party member in 1938 upon Gütt's urging. Kröner, Von der Rassenhygiene zur Humangenetik, p. 37, dates Lenz's admission to 1937. - Lenz's denazification document of 6/6/1949 states that Lenz had been a member of the NSV since 1935, and joined the NSDÄB, supposedly under compulsion, on May 1, 1937, and the NSDAP, also in the year 1937. MPG Archive, Dept. II, Rep. 1 A, PA Lenz. No indication of Lenz is included in the BDC Inventory 3100 (NSDAP central records) and 3200 (NSDAP local group file) in the Federal Archive in Berlin.

${ }^{266}$ According to Kröner, Von der Rassenhygiene zur Humangenetik, p. 28, who sees - besides Walter Groß - Leonardo Conti as the driving force in the background. However, Conti was not yet in such a key position in 1937/38 and did not participate actively in the fortunes of the KWI-A.

${ }^{267}$ Ibid., p. 39. Of the assistants at the KWI-A, it appears that Peter Emil Becker was the only nonmember of the NSDAP after 1933. Verschuer's Frankfurt institute, in contrast, was "a real reservoir of old combatants" (ibid.).
} 
closely connected with his plans for reorganizing the institute, which were not to be realized without strong political cover. An evaluation by the Race Policy Office of the NSDAP, no longer preserved in the archives, apparently reached a positive assessment. Reichsführer SS Heinrich Himmler, when asked for an opinion by the staff of the office of the Führer's deputy, offered support for Fischer and Lenz in 1938, arguing

[T] hat through their scientific work in recent years both have made significant contributions to the fortification and scientific acknowledgement of the racial elements of the National Socialist world view. I am convinced that both Fischer and Lenz, despite a few remaining misgivings, can be admitted to the party. I even believe that the admission is a political necessity of sorts, for we cannot use the power of these two men for the scientific fortification of the party on the one hand, and reject them as party comrades on the other. ${ }^{268}$

Meanwhile, the admission proceedings dragged on exceedingly long. On December 12, 1939 the staff of the Führer's Deputy informed the Reich Treasurer of the NSDAP that Reichsgesundheitsführer Conti approved Fischer's application for admission and that Staff Chief Martin Bormann (1900-1945) had also given his go ahead. Rapid processing was requested. ${ }^{269}$ According to this letter, Fischer had submitted his official application for admission on November 17, 1939. According to the files of the local NSDAP group, admission was not applied for until December 28, 1939. Whatever the date of the application: From January 1, 1940 on Eugen Fischer was a member of the NSDAP. ${ }^{270}$ At the same time Fischer apparently induced his designated successor Verschuer to join the NSDAP. The latter became a party member on July 1, 1940, while still in Frankfurt. ${ }^{271}$ Fischer congratulated Verschuer upon his admission to the party, commenting "I believe that the affiliation is correct and necessary, apart from the associated internal attitude [...]." ${ }^{272}$ After taking over the institute in Dahlem, Verschuer went even further and joined the NSDÄB. ${ }^{273}$

At this point in time, Verschuer - despite his enduring links to the Bekennende Kirche ("Confessing Church") - had long since come to terms politically with the National Socialist regime. He had even made himself indispensable as a human geneticist, race hygienist, and "genetic physician" and cooperated with the regime. The lecture about "The Genetic Image of Humans," which Verschuer held for the

\footnotetext{
${ }^{268}$ Himmler to Stab des Stellvertreters des Führers, 17/8/1938, BArch. Berlin, BDC, DS G 117. Lösch, Rasse, p. 276, also cites this letter, but does not mention any date. And indeed, the date would not fit in well with his hypothesis that Fischer changed his opinion about joining the party only under the impression of the outbreak of the war, as he then had the need "to want to and have to prove his patriotism." (ibid., pp. $275 \mathrm{f}$.).

${ }^{269}$ Ibid., p. 276 (note 103).

${ }^{270}$ BArch. Berlin, BDC, 3200, E 0051.

${ }^{271}$ Ibid., S 0085 and X 0063.

${ }^{272}$ Fischer to Verschuer, 30/9/1941, MPG Archive, Dept. III, Rep. 86 A (Münster), No. 9. The membership card had been issued to Verschuer on April 30, 1941.
}

${ }^{273}$ Kröner, Von der Rassenhygiene zur Humangenetik, p. 33. 
Main Assembly of the Kaiser Wilhelm Society in Breslau on May 24, 1939, culminated in a clear avowal to scientific policy consulting:

The parallel progression of political and scientific thought is no coincidence, but an internal necessity. [...] We genetic biologists and race hygienists [...] remain in the peace of our scientific research activity from the interior conviction that on this field, too, battles of major importance are being fought for the continuity of our Volk. ${ }^{274}$

However, even as director of the KWI-A he was sometimes subjected to political pressures. With his very first lecture as a newly appointed member of the Prussian Academy of Sciences on November 10, 1943 he offended party circles. Under the title Erbanlage als Schicksal und Aufgabe ("Genetic Disposition as Fate and Function") Verschuer took his audience on a tour d'horizon through the regions of higher Mendelism and phenogenetics. Certainly: Verschuer criticized the naive dogma of heredity predominant in higher Mendelism. "For in many cases genotype and race were regarded far too simplistically in terms of materialistic determinism - as the sole source of all life performance, even of intellectual power, especially for culture and history." 275 But at the same time Verschuer made it perfectly clear that it was hardly his intention to explode the structure of genetic determinism:

\begin{abstract}
After these results of genetic and race research, is it justified to assert that genetic disposition is fate? Yes and no! Through genetic disposition, certain fateful limits are determined for the development of each individual. A Negro cannot produce any white children, the genetically feeble-minded have predominantly feeble-minded children, certain defects are passed down according to familiar rules, etc. These are limits that are becoming ever more clearly and definitely demarcated through our research. They cannot be transcended. ${ }^{276}$
\end{abstract}

What could appear offensive, however, were the social and moral conclusions Verschuer drew from the insights of higher Mendelism and phenogenetics: In terms of their genetic dispositions, Verschuer grouped people into a three-level model, arrayed between the two poles of "fate" and "function." Verschuer located the majority of people on the third and highest level: In their genetic dispositions lay "a fateful predetermination only very weakly [...] concealed," they had a "great breadth of possibilities for development." 277 The shaping of the phenotype on this third level was the task of the individual and of society. The people on the second, intermediate level may carry the disposition for serious diseases and disabilities with them, but these appear either not at all or only weakly in the phenotype due to the oscillation of manifestation, and in any case can be compensated for by measures of prevention or rehabilitation. On this second level the molding of the phenotype lay between fate and function. As examples Verschuer named club foot and congential hip luxation. ${ }^{278}$ From his comments clearly proceeded that he believed that all possibilities for orthopedic rehabilitation must be exhausted - he was well

\footnotetext{
${ }^{274}$ Verschuer, Erbbild vom Menschen, p. 12.

${ }^{275}$ Verschuer, Erbanlage als Schicksal und Aufgabe, p. 24 (original emphasis).

${ }^{276}$ Ibid., p. 16 (original emphasis).

${ }^{277}$ Ibid., p. 19 (original emphases).

${ }^{278}$ Ibid., pp. 10 f., 18.
} 
advised to factor out the question of race hygiene sterilization at this juncture, since both conditions were officially considered to be indications for sterilization, a position that Verschuer and his colleagues, as we will show later, did not share. On the first and lowest level, finally, Verschuer placed people with serious genetic defects, whose manifestation was not mediated by other factors - "association with other genes," "course of development," "external influences." ${ }^{279}$ On this level the phenotype was "to be accepted as determined by fate." Nevertheless, with a view to these humans as well, Verschuer argued in terms of the dualism of fate and function. Although their genetic dispositions had to be "accepted as given by fate," the affected confronted a double function:

First, even with a serious genetic defect, it is possible to give one's own life higher value and deeper meaning. Just think of the extraordinary achievements of the blind and deafmute. Yes, even a mentally retarded person can still carry out useful work and distinguish himself through loyalty, love and the spirit of sacrifice. Second - and this demands a selfless readiness to make sacrifices - for the welfare of the Volk, the serious genetic defect must be eliminated by forgoing propogation. ${ }^{280}$

This passage could be understood as a criticism of the "euthanasia" under way since 1940, which had already claimed the lives of over 100,000 mentally ill and mentally disabled by this time - and it appears that party circles understood it as such. Even more important: It was probably so intended. At this juncture Verschuer made clear that he would continue to actively support eugenic sterilization that could be legitimated with the moral philosophy and theology of the idea of sacrifice - a position which Verschuer had advocated since the final years of the Weimar Republic -, but rejected for ethical reasons the murder of the mentally ill and mentally disabled. What's more, he openly repudiated the "breeding of the Übermensch" in Friedrich Nietzsche's terms as the basic motif for race hygiene - he wanted to restrict race hygiene to its function as "custodian of the genotype of the race." 281

As demonstrated, Verschuer's lecture included some critical tones that could not have pleased the makers of National Socialist genetic health policy. But an entry in the diary of Ulrich von Hassell (1881-1944) shows that Verschuer's lecture could be interpreted differently as well:

For me, a lecture on race policy for the Berlin circle of the German Academy was indicative of the level of some sectors of German science. The speaker was Prof. von Verschuer, the man whom E. Fischer dared to propose as his successor in the Mittwochs-Gesellschaft. Superficial prattle tailored to the purposes of party politics, truly a disgrace. ${ }^{282}$

Nevertheless: what appeared as pseudoscientific party propaganda to a member of the resistance provided for unrest in sectors of the party. On April 25, 1944,

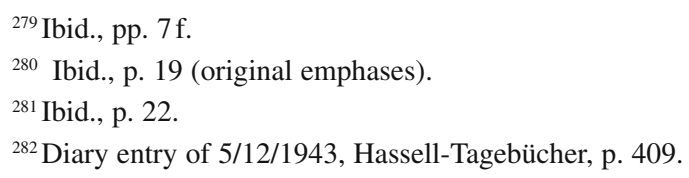


that is, a considerable time after the lecture, ${ }^{283}$ Verschuer related in a letter to Fischer:

Yesterday afternoon I visited [Walter] Groß in his new office in Babelsberg, a country house in a beautiful setting. We conversed for $2 \frac{1}{2}$ hours in a very friendly and mutually obliging tone. He confirmed that he found nothing objectionable in the content of my lecture to the academy, and that my depiction and my standpoint were irreproachable. Incorrect reporting and the misleading interpretation of individual passages have caused political turbulence. However, I got the impression that he will put an end to the matter. I made an agreement with him to submit to him any publications that encroach upon the area of race policy for fine tuning. So I hope that our friendly terms are restored, and that in future he will not be so easily disquieted by such yapping and put the over-zealous curs back on their chains. ${ }^{284}$

The incident is further exemplary evidence of the fact that, within the alliance between science and politics, it was ultimately the political decision makers who made the rules. Hans-Peter Kröner's interpretation must be endorsed, that Verschuer's account of his meeting with Groß promoted his own self-deception: With the arrogant gesture of the academic, he required every effort to conceal from himself and his mentor that he - the director of a Kaiser Wilhelm Institute - had been "muzzled" 285 by one of the National Socialist satraps. After the war, Verschuer, together with his "whitewashers," greatly exaggerated the danger that threatened him from this direction. ${ }^{286}$ Politically, he deviated from the line of state and party only in part. Aside from the issue of "euthanasia," broad consensus predominated in genetic health and race policy. As will be shown in the next section, Verschuer and his staff legitimated and propagated this policy, tended to the scientific substrate, provided practical support and did not hesitate to use the National Socialist politics of genocide in order to acquire scientific "material."

\subsubsection{Lecturing Activity}

Until well into the year 1944, the staff of the KWI-A, hardly hampered by the circumstances of the war, undertook lecture trips all over Germany and Europe. The lectures at universities and to scientific societies were attended by "science camps"

\footnotetext{
${ }^{283}$ Thus it is hardly possible to say that Verschuer was "invited to report" to Groß. According to Kröner, Von der Rassenhygiene zur Humangenetik, p. 34.

${ }^{284}$ Verschuer to Fischer, 25/4/1944, MPG Archive, Dept. III, Rep. 86 A (Münster), No. 9.

${ }^{285}$ Kröner, Von der Rassenhygiene zur Humangenetik, p. 34. In his memoirs, Verschuer stated that, because of his membership in the Prussian Academy of Sciences, Groß understood that he "could not muzzle" Fischer in a public lecture. Verschuer, Erbe - Umwelt - Führung, "Direktor des Kaiser-Wilhelm-Institutes für Anthropologie, menschliche Erblehre und Eugenik (seit 1942)" section, p. 11, MPG Archive, Dept. III, Rep. 86 A, Nos. 3-1.

${ }^{286} \mathrm{Cf}$. on this Adolf Butenandt/Max Hartmann/Wolfgang Heubner/Boris Rajewski, Denkschrift betr. Herrn Prof. Dr. med. Otmar Frhr. v. Verschuer, September 1949, Archive of the University of Frankfurt/Main, Dept. 13, No. 347, pp. 473-485, here: p. 477; Fricke, Kirchliches Urteil über die Persönlichkeit und die wissenschaftliche Arbeit von Herrn Professor Dr. Freiherr v. Verschuer, 26/10/1945, ibid., pp. 427-428, here: p. 428.
} 
(Wissenschaftslager) - thus in April 1942 the entire staff of the institute participated in a "Science Camp of the Race Biologists" (Wissenschaftslager der Rassenbiologen) in Bad Nauheim, held by the Reichsdozentenführung ("Reich Leadership of Lecturers"), at which Fischer and Verschuer held the main lectures. ${ }^{287}$ This scientific lecturing activity in the wider sense was supplemented with appearances at events organized by the Reichsgesundheitsführer, the Reich Youth Leadership and the Inspector of the Army Medical Corps. ${ }^{288}$ In January 1942, for instance, Karin Magnussen gave a lecture about "Population Policy Problems in the War" to youth group leaders of the Nazi Women's Association (NS-Frauenschaft), ${ }^{289}$ and in February 1944 Hans Nachtsheim spoke to the Greifswald branch of the German Society for Race Hygiene on the topic "What Can the Study of Genetically Diseased Mammals Contribute to the Investigation of Human Genetic Diseases?". 290

Of particular importance were the lectures by the director and departmental chiefs of the KWI-A in occupied and allied Europe. In the 1941/42 fiscal year Eugen Fischer held lectures in Bucharest, Brasov, Sibiu, Temesvar, Cluj, Budapest, Paris, Paris, and Zagreb, Kurt Gottschaldt in Helsinki and Jyväskylä. "All of these lectures," which, as Fischer emphasized in his activity report, were held at the request of the Foreign Office and the Reich Ministry for Education, "served to promote cultural solidarity with these countries and spread propaganda for Deutschtum ('Germanness')." ${ }^{\prime 291}$ Otmar von Verschuer continued the foreign activities of his predecessor. In December 1942 he held lectures in Brussels "on behalf of the military commander for Belgium" (to members of the military administration) and at the University of Ghent "to establish contact with Flemish cultural circles." ${ }^{292}$ In

\footnotetext{
${ }^{287}$ Verschuer, Tätigkeitsbericht 1942/43, MPG Archive, Dept. I, Rep. 3, No. 20.

${ }^{288}$ Verschuer, Tätigkeitsbericht 1943/44, MPG Archive, Dept. I, Rep. 3, No. 22.

${ }^{289}$ According to her own statements, in addition to this talk Magnussen held only two other "purely scientific" lectures in 1944 (about "twin research and modern genetic research"). After leaving the KWI-A, from September 1944 to January 1945 she held "scientific lectures (as lecturer of the Race Policy Seminar) about genetic theory (cytology, chromosome theory, modification, and mutation, selection, the laws of heredity and speciation, the bastardization problem, heredity in humans, twin research, breeding research in animals and plants, etc.) for the staff of the Race Policy Office. Voluntarily!” Karin Magnussen, Verzeichnis meiner Veröffentlichungen, MPG Archive, Dept. I, Rep. 3, No. 26.

${ }^{290}$ Nachtsheim's notes for Tätigkeitsbericht 1943/44, MPG Archive, Dept. I, Rep. 3, No. 22.

${ }^{291}$ Fischer added: "Indirectly, in the same sense it must be designated as effective that a relatively large number of foreigners work at the institute as guest scholars." Fischer, Tätigkeitsbericht 1941/42, MPG Archive, Dept. I, Rep. 3, No. 19.

${ }^{292}$ Verschuer to Fischer, 22/10/1942, MPG Archive, Dept. III, Rep. 86 A (Münster), No. 9. Cf. Verschuer to Fischer, 7/1/1943, ibid.; Verschuer, Tätigkeitsbericht 1942/43, MPG Archive, Dept. I, Rep. 3, No. 20; Verschuer, Erbe - Umwelt - Führung, "Direktor des Kaiser-Wilhelm-Institutes für Anthropologie, menschliche Erblehre und Eugenik (seit 1942)" section, p. 3, MPG Archive, Dept. III, Rep. 86 A, No. 3-1. At this opportunity Verschuer made the acquaintance of the Belgian fascist leader Léon Degrelle (1906-1994). Cf. Verschuer, Stellungnahme zu den Angaben, die sich auf meine Person beziehen und in der "Neuen Zeitung" No. 35 of 3/5/1946 unter der Rubrik "Kunst und Kultur in Kürze" in der Notiz "Vertriebene Wissenschaft" erschienen sind, Archive of the University of Frankfurt/Main, Dept. 13, No. 347, p. 178.
} 
1943/44 he spoke in Prague, Danzig, Zagreb, Graz, Vienna, and Mähritz. ${ }^{293}$ Gottschaldt, too, continued to travel through occupied Europe. In 1942/43 lectures in Vienna, Budapest, Strasbourg and Innsbruck were on his itinerary; he further participated in the above-mentioned German-Japanese Science Camp in summer 1942. ${ }^{294}$ In May 1943 and January 1944 Hans Nachtsheim appeared in Vienna. ${ }^{295}$ In addition to their foreign travels, in February 1941 Fischer and Verschuer held lectures at the Führerschule der deutschen Ärzteschaft ("Leadership School of the German Medical Fraternity") on the occasion of a "joint camp" for physicians from Alsace, Luxembourg and the Netherlands in Alt-Rehse. ${ }^{296}$

Beyond their general foreign policy function, many of the lectures abroad apparently had the additional task of bringing functional elites from the field of medicine in the occupied and allied states "on course" with National Socialist genetic health and race policy. Thus in a dual sense they were a "service" the institute performed for the political rulers. However, they were also in the institute's own interest, as they can be regarded as part of a strategy to shape a continental European research alliance under German leadership after the collapse of the international scientific community. In this view, utilizing a large number of foreign guest scholars at the KWI-A, too, made a virtue of necessity. Beyond this Fischer and Verschuer endeavored to cultivate good relations with scientists from the allied and neutral countries, e.g. George Montandon, professor of ethnology at the Ėcole d'Anthropologie in Paris, and Guido Landra of Italy. ${ }^{297}$ When the Foreign Office of the Dozentenschaft in Frankfurt offered in November 1940 to cover the costs of sending scientific publications abroad as a gift to foreign scholars, Verschuer's list of recipients included Ernst Hanhart (Zurich), Elis Essen-Möller ( ${ }^{*} 1870$, Lund), Torsten Sjögren

\footnotetext{
${ }^{293}$ Verschuer, Tätigkeitsbericht 1943/44, handwritten marginal, MPG Archive, Dept. I, Rep. 3, No. 22, Verschuer, Erbe - Umwelt - Führung, "Direktor des Kaiser-Wilhelm-Institutes für Anthropologie, menschliche Erblehre und Eugenik (seit 1942)" section, pp. 9f., MPG Archive, Dept. III, Rep. 86 A, No. 3-1. In Zagreb Verschuer spoke "to the Croatian medical fraternity" about "twin research," in Graz to the "local association of physicians," in Vienna to the "Freundeskreis der Deutschen Akademie". - In April 1943 Verschuer was apparently also on a lecture tour through Holland. Verschuer to Fischer, 31/3/1943, MPG Archive, Dept. III, Rep. 86 A (Münster), No. 9. In a further letter to Fischer Verschuer reports that he held two lectures at a congress of German physicians near Bratislava, Slovakia. Verschuer to Fischer, 20/9/1943, ibid.

${ }^{294}$ Gottschaldt, notes for Tätigkeitsbericht 1942/43; Verschuer, Tätigkeitsbericht 1942/43, MPG Archive, Dept. I, Rep. 3, No. 20.

${ }^{295}$ Erbkrankheiten beim Tier in ihrer Bedeutung für die menschliche Erbpathologie ("Genetic Diseases in Animals and their Importance for Human Genetic Pathology"), joint session of the Vienna Medical Society and the Vienna Veterinary Society on May 12, 1943, "Erbkrankheiten des Blutes in vergleichender Betrachtung" ("Genetic Diseases of the Blood in the Comparative Perspective"), lecture to the Wiener Kulturvereinigung (Vienna Federation of Culture) on January 27, 1944. These data are found in Nachtsheim's draft for Tätigkeitsbericht 1943/44, MPG Archive, Dept. I, Rep. 3, No. 22.

${ }^{296}$ Fischer to Verschuer, 20/2/1941, MPG Archive, Dept. III, Rep. 86 A (Münster), No. 9.

${ }^{297} \mathrm{Cf}$. the expert opion about Landa issued by Eugen Fischer, ibid. - Montandon was the translator of the French edition of Verschuer's Leitfaden zur Rassenhygiene.
} 


\title{
(Göteborg), Tage Kemp (Copenhagen), Thordar Quelprud (Oslo), ${ }^{298}$ Wouter Ströer (Groningen), Petrus J. Waardenburg (Arnhem) and Mihali Malán (Budapest). ${ }^{299}$
}

Contacts to scientists from the "antagonistic foreign countries" were disrupted as a natural course of the war. However, Otmar von Verschuer regarded science, too, as part of the military campaign. While he was at pains to keep himself up-todate on the scientific production of the "enemy states," he did his best to conceal this from foreigners. This became particularly clear in March 1944, when he rejected Fischer's proposal to publish the Swiss guest scholar Erik Hug's summary of the last volumes of the most important anthropological and eugenic journals from the Great Britain and the USA in one of the journals he edited:

\begin{abstract}
I believe [...] that we [should] take cognizance of the journals from enemy countries for internal use only and evaluate the most important results of these in our own scientific work. In contrast, I have reservations about giving a complete summary of the journals of the enemy foreign states in a German journal. I hardly believe that the Americans or English, who have taken so little notice of German scientific production, now during the war present summaries about German scientific journals. Therefore my standpoint for the duration of the war is: To the extent it is possible, monitor the enemy foreign literature secretly, but give notice of this to the outside world only when citing especially important works in scientific journals. ${ }^{300}$
\end{abstract}

\footnotetext{
${ }^{298}$ In 1942 the National Socialists appointed Quelprud director of a new Genetic Biology Institute (Arvebiologisk Institutt) at the University of Oslo. Fischer pulled the strings in the background, whereby he did not shrink from denouncing Norwegian colleagues: "About him [Quelprud] I may inform you in confidence that he is repressed by the Oslo zoologist and geneticist Professor Mohr, who is a Socialist married to a Communist, and also by the professor for genetics in Oslo, Mrs. Kristine Bonnevie [1872-1949], a half-Jew, and by others of that circle because he is sympathetic to Germany [...]." Fischer to de Crinis, 2/2/1942, quoted in Kröner, Von der Rassenhygiene zur Humangenetik, p. 58. After belonging to the National Socialist Party of Norway (Nasjonal Samling) from 1933/34 to 1936, Quelprud left the party because of the biological ideas in the party newspaper, rejoining in 1941 only to leave again in 1944. Cf. Roll-Hansen, Nowegian Eugenics, pp. 179f., 193 (note 88).

${ }^{299}$ Verschuer to Fischer, 19/11/1940, MPG Archive, Dept. III, Rep. 86 A (Münster), No. 9.

${ }^{300}$ Verschuer to Fischer, 2/3/1944, ibid. It was, Verschuer continued, "extremely desirable" that knowledge about the research in the allied states made its way to Germany, and he supported all endeavors in this direction, e.g. "setting up an international, neutral, bibliographic service by Staehelin or Brugger in Switzerland." On the initiative of the director of the Department for Genetic Research at the Psychiatric Clinic of the University of Basel, John E. Staehelin, Verschuer remarked on March 27, 1943, that it meant "a gap for our research work that the literature of enemy foreign states and overseas is practically inaccessible. The collection of all relevant offprints and monographs proposed by Professor Staehelin and the publication of a periodical, complete bibliographic directory therefore finds my support. In contrast, I reject the publication of an annual information bulletin about the works in progress of the individual scientists for the duration of the war. This would give insight into inter-German circumstances that could not be reconciled with the conditions of war" (Verschuer to the Reichsministerium für Wissenschaft, Erziehung und Volksbildung, 27/3/1943, BArch. Berlin, R 4901/3199, p. 5).
}

In his letter of March 2, 1944 Verschuer further informed Fischer that he had registered with the "Procurement Office of German Libraries for several journals and from there recently received 5 issues of the Annals of Eugenic[s], which were loaned out to me for 10 days. The time was just sufficient for me to have the works most important for us photocopied." After all, he was a subscriber to the journal Fortschritte der Medizin ("Progresses in Medicine"), which had developed into a "reference work of the foreign medical press." "However, this journal is only dispensed for 


\subsubsection{Race Hygiene, Sterilization, and "Euthanasia"}

On May 10, 1940, Fritz Lenz addressed an extensive letter to the editorship of Das Schwarze Korps. He took reference to an article of April 11, 1940 entitled Eine Frau hat das Wort ("A Woman Has Her Say"). The anonymous author had demanded, in view of the surplus of women after World War I, that the state should create incentives for women of 30 who were still single to become unmarried mothers: Such single mothers should receive a higher income than childless married women of the same age; their dual role as mother and career woman should be accommodated by flexible working hours; they should receive a one-off benefit similar to the marriage loan; "for the less well off," further, "current state supports [were] to be guaranteed." Prerequisite for this benefit was the "genetic health" of the mother and the father - sperm donations were to come from single young men who had not yet started their own families. Finally, the anonymous author, "for the protection of the honor" of the single mothers, had demanded that "anyone who reproached the morals of a single mother" be sentenced to prison on principle.

Lenz responded to these proposals with sharp critique. Higher income for single mothers which, as Lenz emphasized, would have to be financed by state subsidies, was not only economically intolerable, especially since, for reasons of equal treatment, the demand would "as a consequence [...] would have to amount to ongoing support for all mothers." Under aspects of race hygiene, too, it would always make more sense to support married mothers. The particular displeasure of the Nestor of the race hygiene movement was evoked by the proposal to guarantee ongoing support for single mothers who were less well off: "A similar demand was raised in the Reichstag of the Weimar system by the Communists." Lenz warned that measures of this kind would "encourage the propagation of elements that [could not] demonstrate any sufficient performance as a result of mental or physical weakness and thus also [could not] exhibit any sufficient income." There was the danger of "adverse selection," which, as Lenz argued with reference to possible concealed genetic dispositions, could not be avoided by making the "genetic health" of the men and women involved a prerequisite, either: "By no means can the danger of a preferential propagation of inferior race elements be averted in this manner."

Under quasi educational aspects Lenz pointed out that the proposals would make necessary "special legislation" to expressly exempt the fathers of the children from support payments, "while in recent years the tendency has been to increase the responsibility of the father, in economic terms as well." The whole scheme boiled down to "state-approved temporary marriages of uncertain duration, which moreover would even be privileged by the fact that the state would take over the costs of

official use and under the obligation that it be kept under lock and key, to certain subscribers who must pledge their confidentiality with a signature on the back cover."

At another juncture Verschuer reported that he received, "from the exchange service," the Eugenics Review, of which he had photocopies made. Verschuer to Fischer, 11/8/1944, MPG Archive, Dept. III, Rep. 86 A (Münster), No. 9. 
bringing up the children.” This would have to weaken marriage as such. Here Lenz argumented quite conservatively and fundamentally, but not consistently in terms of race hygiene. He did see the childlessness of many women from the generation of the World War I as a race hygiene problem, but to him illegitimate motherhood did not seem a suitable solution under moral aspects - when, then polygamy instead: "Purely objectively" he would hold the "permission of a [...] limited number of second wives to be the relatively best solution; but the moral tradition of the German Occident appears to virtually exclude such a solution." "Breaking the moral tradition of a nation" was, however, "always perilous." ${ }^{301}$

Lenz did not insist that his reply be printed in Das Schwarze Korps. But he did call upon both the editorship and the author to enter into a critical dialog - to no avail, as the editorial board of Das Schwarze Korps did not react at all. Lenz addressed copies of his letter to the RuSHA, the Race Policy Office and the German Family League of the Reich (Reichsbund Deutsche Familie).

At the close of his letter Lenz illustrated his conception of state measures to increase the birthrate among married couples. A "state obligation to bring up children" should be introduced, in keeping with the principle "Every member of the nation capable of living has the duty to bring up at least four children." Anyone who did not fulfill this obligation should ante up "substitute payments in percentages of his income," which corresponded to "approximately the cost of bringing up children."

Lenz elaborated on this basic idea in an exposé about "Ways to Further Advance in Population Policy," which he wrote at the same time as the protest letter to Das Schwarze Korps. The French campaign had not yet entered its decisive phase, but Lenz appeared optimistic that the end of the war was immediately imminent and would offer "a unique opportunity for generous population policy." Because the birth cohorts since 1915, which were already not terribly strong as a consequence of World War I, had been weakened further by the losses in the war from 1939 to 1940, the idea was to induce the birth cohorts before 1914 to bring up as many children as possible. "Against birth premiums and child subsidies," Lenz announced yet again apodictically, there were "serious race hygiene objections." The experiences with marriage loans were, under quantitative aspects alone, "by no means encouraging." Each marriage supported by a marriage loan accounted for "slightly less than one child." What is more: "From the perspective of race hygiene there is hardly a reason to regret that only meager funds are available for such benefits at this time." ${ }^{302}$ In contrast, Lenz expressly advocated burden sharing for families through higher taxes for families with no or only few children. The tax increases dictated by the war seemed to offer a convenient opportunity to engineer such a

\footnotetext{
${ }^{301}$ Lenz to the editorship of Das Schwarze Korps, 10/5/1940, MPG Archive, Dept. III, Rep. 86 B, No. 10, pp. 8-14, quotes: pp. 9-14.

${ }^{302}$ This view was backed up by a later study from the KWI-A: "Gründler performed follow-up examinations on pairs who were denied the marriageability certificate, and in doing so found important new aspects for marriage consulting and the execution of the marriage health law." Verschuer, Tätigkeitsbericht 1942/43, MPG Archive, Dept. I, Rep. 3, No. 20. Gründler was listed as a doctoral student of the KWI-A in this year.
} 
burden-sharing scheme; the idea was "to make a demographic policy virtue out of the financial necessity of the war." 303 The core of the tax policy concept worked out to the last detail by Lenz was the proposal that the war surtax on income be eliminated after the end of the war only for families with four or more children. Tax advantages for childless married couples were to be omitted, just as the temporary tax relief for young couples and the enduring tax break for couples with grown children. Both parents of illegitimate children were to be allowed to deduct a child from their taxes, but only by half. Only families with many children were to enjoy full deductions from property and inheritance taxes. Finally, Lenz developed a mandatory savings system for peasant families, to finance the compensation paid out to the daughters and sons who did not inherit property - if a peasant family had fewer than four children, part of the money saved would fall to the state. In fact, Lenz's proposals - measured against the tax level before the beginning of World War II - amounted to a constant tax burden for families with many children and enormous tax increases for everyone else.

What is interesting is that Verschuer, to whom Lenz sent both of his documents for his perusal, responded immediately and declared himself in complete agreement with the contents. He expressly subscribed to Lenz's thesis that the propaganda for illegitimate children evoked the "race hygiene danger" of "adverse selection." He proposed publishing Lenz's tax policy exposé in the Erbarzt. ${ }^{304}$ Yet Lenz had misgivings, since his proposals collided with the tax policy of the relevant state secretary in the Reich Finance Ministry, Fritz Reinhardt (1895-1969), whom he did not want to provoke by publishing the exposé. However, Lenz reported, it had been forwarded to Reinhard via the Race Policy Office. ${ }^{305}$

In 1943 Lenz decided to publish his ideas after all, in the Archiv für Rassen- und Gesellschaftsbiologie under the title Gedanken zur Rassenhygiene (Eugenik) ("Thoughts on Race Hygiene (Eugenics"). With this he spurred into action the press department of the Reich government in the Reich Ministry for Propaganda and Enlightenment of the Nation, which ordered that the passages about relieving families of the tax burden be struck. ${ }^{306}$ New in this version of 1943 was that Lenz demanded compulsory employment for childless and "child-poor" women. ${ }^{307}$

While Lenz continued his efforts on the path of scientific policy consulting to secure recognition in population policy for a program of positive eugenics, Verschuer and his staff continued to be in demand as experts and evaluators whenever questionable cases arose in the application of the $\mathrm{GzVeN}$. As has been shown above, after the changing of the guard at the head of the institute, genetic pathology research in Dahlem was consistently oriented toward this practical application, in

\footnotetext{
${ }^{303}$ Lenz, Wege weiteren Vormarsches der Bevölkerungspolitik, n.d. [June 1940], MPG Archive, Dept. III, Rep. 86 B, No. 10, pp. 15-21, quotes: p. 15.

${ }^{304}$ Verschuer to Lenz, 12/6/1940, ibid., p. $22 \mathrm{f}$.

${ }^{305}$ Lenz to Verschuer, 17/6/1940, ibid., p. 24f.

${ }^{306} \mathrm{Cf}$. the documents printed as facsimiles in: Koch, Humangenetik, pp. 108-110.

${ }^{307}$ Lenz, Gedanken zur Rassenhygiene, p. 97.
} 
order to "clear the complex jungle of the activity of producing expert opinions." 308 Due to the incomplete knowledge about the heredity of the diseases and disabilities listed in the catalog of indications of the GzVeN, since 1934 a jumble of contradictory decisions had resulted, and the initial enthusiasm of the race hygienists had given way to a kind of "hangover." 309 In accordance with the insights of higher Mendelism, since 1938 Verschuer had urged that the Hereditary Health Court proceedings be based not on the clinical diagnosis, but solely on the genetic diagnosis, to be reached through intensive genealogical studies. ${ }^{310}$ This had the consequence that in some cases which had fallen under the GzVeN as a matter of course up to that point, Verschuer and his staff advised against sterilization. In one case this consistently pursued line went too far for even Verschuer's friend and teacher Fischer. When in 1940 Verschuer's employee Heinrich Schade advocated the interpretation that certain defects of the limbs were not genetic and thus, must be excepted from sterilization, ${ }^{311}$ Fischer lodged vehement protest with Verschuer:

\begin{abstract}
With a degree of shock I read the paper by Schade about the defects of the limbs. I do not hold to be correct the conclusions that heredity was not present in general, presented here in apodictic form. Here Goethe is wrong!! All fun aside. Schade is, of course, right, that heredity is not proved in these cases. But for schizophrenia we also do not know what kind of and how many genetic factors are the basis. For the limbs there could hardly be any single, separate gene for each form and each location of defects, but rather different kinds, such as those which govern the development processes chemically. [...] There is not only this theoretical side to the matter, however. In terms of praxis, Schade arrives at the conclusion that one may not sterilize these cases unless another identical case was found to have occurred in the family. And this is extremely rare for today's small families. Then we would have the situation, which seems intolerable to me, that conditions like cleft palate, club foot and hip luxation are sterilized as serious physical defects, but when an entire extremity is missing, or when both hands are completely crippled, sterilization does not take place. The public knows both groups as congenital. Now the one defect, in fact the lesser, is regarded as congenitally inherited and thus to be sterilized; the other, more serious one, is regarded as congenital but not inherited, and thus not to be sterilized. The Volk does not understand this. And for us, too, it goes against every feeling of justice. Perhaps we were really somewhat hasty with the presumption of heredity in the case of defects. If one believes that, then the consequences must also be drawn for luxation, harelip, etc. I do not believe it personally. I am of the opinion that Schade went too far and allow only that while we do not know the individual genetic process, genes are the cause. ${ }^{312}$
\end{abstract}

Here Fischer pursued the dual logic of an applied science, which must always attempt to combine the logic of science with the logic of politics. Its recommendations to politics are always the product of several factors: scientific knowledge, the consideration of the practical utility of a measure, the expectation of its political feasability and its cultural acceptance, and finally its ethical admissibility. Thus,

\footnotetext{
${ }^{308}$ Weß, Humangenetik, p. 174.

${ }^{309}$ Ibid.

${ }^{310} \mathrm{Cf}$. e.g. Verschuer, Unfruchtbarmachung.

${ }^{311}$ Schade, Untersuchungen.

${ }^{312}$ Fischer to Verschuer, 2/7/1941, MPG Archive, Dept. III, Rep. 86 A (Münster), No. 9. Cf. also Weß, Humangenetik, p. 176.
} 
many scholars of the human sciences in the Third Reich advocated large-scale eugenic sterilizations, although it was quite clear to them that they were on shaky ground scientifically. The heritability of one or the other clinical picture constituted a plausible assumption, but one that in many cases required further empirical confirmation. That this assumption was sometimes presented to the outside world as a fact - to the public, but also to the state - is by no means unusual, but rather is part of everyday science even today. They believed that the empirical proof for the seemingly evident facts of the case could be presented afterward, sooner, or later. ${ }^{313}$ Fischer's stated opinion is practically paradigmatic for this position.

Yet Verschuer did not follow his mentor on this path. On the contrary: he countered Fischer's argument that if one did not want to sterilize people with deformed limbs, then "cleft palate, club foot and hip luxation" would also have to be deleted from the GzVeN's catalog of indications, by aspiring to that very end. As regarded cleft lip, cleft jaw, and cleft palate, since the late 1930s Verschuer had proceeded from the assumption of a high degree of heterogeny - based on Josef Mengele's dissertation, by the way. But the consequence of this was that heredity had to be checked for in each individual case. And according to the testimony of Gerhard Koch mentioned above, in July or August 1943 the Genetic Pathology Working Group under Verschuer's direction argued that club foot and congenital hip luxation should no longer be recognized as "genetic conditions" in the sense of the GzVeN. In the first, still-documented sessions of the Genetic Pathology Working Group, the participating scientists had also been extraordinarily reluctant to recommend sterilization in individual cases ${ }^{314}$ - in principle they were in agreement that the heritability of a condition had to be proved with certainty on the basis of family anamnesis in the individual case, whereas the logic of the GzVeN had saddled the subject to be sterilized with the burden of proof: He or she had to prove that in his or her case the general assumption did not hold that the condition was hereditary.

In the judgement of concrete cases, Verschuer consistently held fast to the genetic diagnosis. As a rule, he was extremely reluctant to acknowledge nonscientific considerations, even when they spoke for the subject. This became apparent, for instance, in the different judgements of the very first case dealt with in the Genetic Pathology Working Group, by Verschuer and Lenz. It involved a 35-yearold man, who had gone completely blind at the age of 18 due to Hydrophthalmus congenitus (congenital glaucoma), but had nevertheless graduated from secondary school, worked as a music teacher and piano tuner and led the Association of the Blind of his district, and finally studied law. In 1939 he wanted to marry a healthy teacher, but he was denied the marriageability certificate and an exemption from the regulations of the marriage health law. An application for sterilization in accordance with the GzVeN was rejected, however. The case had been submitted to Verschuer for his expert opinion. In the ensuing discussion about the race hygiene consequences, Lenz argued that the risk of rare, recessive genetic conditions

\footnotetext{
${ }^{313}$ Cf. Roelcke, Programm, p. 57. In general: Schlich, Wissenschaft.

${ }^{314} \mathrm{Cf}$. Grebe, Erbpathologische Arbeitsgemeinschaft.
} 
occuring in the couple's progeny was so low that the couple, which consisted of "personalities of above-average talent and prowess," should not be deprived of the possibility of having children. Verschuer argued against sterilization as well, but believed that according to the GzVeN the man "would have to be sterilized because of genetic blindness, if the hydrophthalmia was definitely genetic in his case, which he [Verschuer] personally did not hold to be proved." By contrast, Lenz was steadfast in his judgement "that even if the heritability of the condition was presumed, the man was not be sterilized, because there was no high probability that genetically ill individuals were to be expected among the progeny. The probability of this was less than $1 \%$, and one may not do without 99 healthy children because of one that might be genetically ill." In the end Lenz and Verschuer came to an agreement, "albeit for slightly different reasons," 315 that in the given case neither sterilization nor a marriage ban was justified. The salient point is that in his argumentation Lenz adhered closely to the letter of the law, to his official interpretation, and above all to the jurisdiction of the Hereditary Health Courts, which had long since begun to grant broader latitude to the criterion of "preservation of life" in their judgements. Verschuer's standpoint that upon proof of genetic blindness the subject was to be sterilized in any case, regardless of all other aspects, amounted in fact to an intensification of the existing legislation and administration of justice. That he decided against sterilization in this concrete case was due solely to the fact that he did not consider the proof of heritability to have been adduced. Here it becomes apparent how misleading it is to use the individual cases in which Verschuer and his staff advised against sterilization as an indication for the fact that the scientists of the KWI-A attempted, as a rule, to exert a moderating influence on the praxis of sterilization. ${ }^{316}$ They wanted to place the sterilization program on a new scientific basis that did justice to the insights of higher Mendelism: Some of the subjects to be sterilized, who up until that time had been sterilized without any hesitation, were thus spared from sterilization. In other cases Verschuer and his staff judged even more harshly than the Hereditary Health Courts.

What is more: as a consequence of Verschuer's position, sterilization legislation had to be extended to the heterozygotic bearers of recessive genes, who had no

\footnotetext{
${ }^{315}$ Grebe, Hydrophthalmus, p. 93.

${ }^{316}$ So Koch, Humangenetik, p. 95. In a case of Paramyotonia congenita (Eulenburg syndrome), a dominant autosomal genetic disorder with occasional muscular rigidity, primarily induced by physical excercise and cold, Gerhard Koch indicated that sterilization was not appropriate. In his memoirs Koch emphasizes that this work "despite my critical opinions on the "Gesetz zur Verhütung erbkranken Nachwuchses,' [was] released for publication in the Erbarzt by the military censors." (ibid., p. 104). Of course, from the perspective of Nazi genetic health policy, there could hardly have been anything objectionable about this article. The passage in question reads: "[Heinz] Boeters holds an application of the G.z.V.e.N. to be unnecessary due to the rarity of myotonical clinical pictures ( 1 of every 30,000-50,000 affected). In the case before us now, too, sterilization does not appear suitable because of the intellectual abilities of the subject. But since it is not to be expected that the disorder will become extinct through self-selection, as a rule marriage and having children should be urgently advised against. [...] Patients with myotonic apraxia are, of course, of no use for military service." Koch, Paramyotonia, p. 173.
} 
clinical symptoms. Verschuer - in contrast to Lenz ${ }^{317}$ - was too cautious to make such a demand publicly, for after all - to the disappointment of many a eugenicist and race hygienist - Hitler and the National Socialists had excepted the healthy bearers of genetic dispositions in their formulation of the $\mathrm{GzVeN}$ (which the Prussian draft of 1932 had not, by the way). Under conditions of war it was not to be expected that they would consent to such an explosive expansion of the sterilization program, which had been geared down in 1939 anyway. Nonetheless, Verschuer and his staff attempted to lay the scientific foundations for such an expansion, as shown by research like Grebe's search for stigmata that would allow healthy bearers of the genes for chondrodysplasia to be identified. In principle and potentially, Verschuer's position amounted to a further intensification of the sterilization legislation.

While the KWI-A continued to fulfill an important consulting function as regarded the sterilization program, as mentioned above, Verschuer distanced himself publicly from the Nazi "euthanasia." In contrast, Fritz Lenz cooperated with the "euthanasia" planning staff to create a legal foundation for the mass murder of the mentally ill and mentally disabled. It has been asserted on several occasions that Lenz had changed his opinion on the question of the "annihilation of life unworthy of life" at the beginning of World War $\mathrm{II}^{318}$ - but this is only partially true. In the third edition of his work Menschliche Auslese und Rassenhygiene (Eugenik) - that is, the second volume of "Baur-Fischer-Lenz," which appeared in 1931 - Lenz had expressed his views on the issue of "euthanasia" at great length, after having made the impression on the public that he unreservedly advocated "euthanasia." On the contrary, Lenz emphasized "that so-called euthanasia [is out of the question] as an essential means of race hygiene." Taking reference to intensified postwar discussion about medically assisted suicide, killing on request and the "annihilation of life unworthy of life," Lenz pled for the view that "euthanasia" was "preeminently a question of humanity. Even the ancient Spartan abandonment of deformed children is still incomparably more humane than today's practice of rearing even the most unfortunate creatures in the name of 'compassion' [...]." ${ }^{319}$ With reference to race hygiene, however, "euthanasia" had no great importance to the extent that the circle of those affected would hardly have the opportunity to propagate - if this danger existed, then it could be prevented by sterilization. What did speak for the painless killing of disabled children from the standpoint of race hygiene is that it would enable the parents to bring another, healthy child into the world. This would also mean that "the question of the marriageability of encumbered persons [could be] judged much more generously than it is today." ${ }^{320}$ For instance, there would be

\footnotetext{
${ }^{317}$ Lenz, Gedanken zur Rassenhygiene, p. 100. At this juncture Lenz also openly demands the inclusion of "asocial" subjects in the sterilization legislation. Ibid., pp. $100 \mathrm{f}$.

${ }^{318}$ So runs the presumption of Rissom, Fritz Lenz, p. 69.

${ }^{319}$ Lenz, Auslese, 3rd edn, p. 306. Here Lenz took express reference to the publication by Karl Binding and Alfred Hoche about the "deregulation of the annihilation of life unworthy of life."

${ }^{320}$ Lenz, Auslese, 3rd edn, p. 307. Lenz argued very similarly in 1938. Cf. idem., Häufigkeit.
} 
fewer misgivings about permitting a marriage between partners who were healthy themselves but known to be bearers of a recessive gene for deaf-muteness, because the deaf-mute children from such a marriage could be killed and thus the parents given the opportunity to have as many healthy children as their economic situation allowed. Although Lenz thus indirectly attributed a eugenic function to "early euthanasia," he persisted in his opinion that "euthanasia" was "hardly $[\ldots]$ so effective a means" under race hygiene aspects "that race hygiene must advocate it." Decisive for Lenz was that through "euthansia" the "respect for individual life, which is an essential foundation of our social order, would experience a critical loss." Although more than a few infanticides occurred for the purpose of family planning even in the Western cultures, "the moral consciousness in the Occident [excluded] a legal license for infanticide." ${ }^{\prime 32}$

In other words: Lenz did hold the killing of disabled newborns to be justifiable in principle as an act of "humanity," but in the early 1930s he still believed that deregulating "early euthanasia" would shock the "moral consciousness" and the "social order." It is presumably not incorrect to presume that Lenz feared "early euthanasia" could become the gateway to the deregulation of abortion for social indications. In principle Lenz adhered to his position. After including the passage about "euthanasia" unchanged in the fourth edition of his work in 1938, in the preface to the publication by Wolfgang Stroothenke about Erbpflege und Christentum ("Care of Genes and Christianity") published in 1940, in which "early euthanasia" was demanded on as a measure of caring for the genetic pool, Lenz reaffirmed his standpoint that "euthanasia" was primarily a question of "humanity." ${ }^{322}$ What Lenz did not write openly, however: apparently he believed the time had come to set about resolving this question.

In any case Lenz - presumably in his capacity as a member of the Expert Council for Population and Race Policy - proved ready to participate in a commission, which probably convened in October 1940, to debate and finalize a draft law to legalize the "euthanasia" program under way since the change of years $1939 / 40 .{ }^{323}$ A number of the physicians represented in this commission belonged to the medical staff of the "euthanasia" program - among them Georg Renno, who had passed through the KWI-A's first annual course for SS trainees - as well as several representatives of the medical administrations of the states, and, finally, the Chief of the Security Police and the SD, Reinhard Heydrich (1904-1942), who was interested in the procedure because at this time he was concerned with the planning for a "Community Alien Law" (Gemeinschaftsfremdengesetz). ${ }^{324}$ The draft law

\footnotetext{
${ }^{321}$ Lenz, Auslese, 3rd edn, p. 307.

${ }^{322} \mathrm{Cf}$. the preface in Stroothenke, Erbpflege.

${ }^{323}$ On the previous history: Roth/Aly, "Gesetz über die Sterbehilfe"; Gruchmann, Euthanasie; Klee, "Euthanasie,” pp. 241 f.; Schmuhl, Rassenhygiene, Nationalsozialismus, Euthanasie, pp. 291-297.

${ }^{324}$ Cf. on this: Ayaß, "Asoziale," pp. 202-209. Otmar von Verschuer also got involved in this discussion. He approved the establishment of a register of "community aliens" in order to attain a "differentiation between those to be eliminated and those to be supported" (Erbarzt 8, 1940, pp. 234f.).
} 
ultimately worked out by this body then presumably bore the title proposed by Fritz Lenz, "Law About Euthanasia for the Incurably Ill." 325 The final version of the draft was not preserved, but the contents of its six articles can be reconstructed on the basis of some of the surviving commission protocols. Apparently the preamble states that people "who because of an incurable disease long for [an end to their suffering]" or "as a consequence of an incurable chronic condition are incapable of productive life," 326 were to be afforded assisted suicide. The first two articles represented slightly modified versions of a draft law debated by the official Criminal Law Commission on August 11, 1939:

\section{$\S 1$ : Anyone who suffers from an incurable disease [that presents a great burden to himself or others or is certain to lead to death] can receive euthanasia upon his express request with the approval of a specially authorized physician. ${ }^{327}$ \\ $\S 2$ : The life of a patient who otherwise would require lifelong custody as the consequence of incurable mental disease can be ended through medical measures unnoticeable for the patient. ${ }^{328}$}

The following four articles regulated the process. The patients were to be registered - unless the patient himself submitted the petition - by the public health officers and institutional physicians. Thereupon an evaluation was to take place by "expert committees," each of which was to include a "specially authorized" public health officer and two medical assessors (psychiatrists). The committees were to be assembled by a "Reich Deputy" to be appointed for the execution of the law. This special agent, vested with far-reaching powers, was also to make the final decision about the petitions for "medical assistance" on the basis of the expert opinions submitted by the expert committees, and to appoint the physicians to perform the procedure. If an executing physician stated that he did not agree with the vote of an expert committee, he could submit a detailed written explanation of his reasons and apply for a new expert opinion by another expert committee.

What role did Lenz play on this commission? According to the protocol he was one of the most eager discussants, and many of the essential formulations of its content were based on his proposals. This began with the title of the draft law. Upon Lenz's suggestion, the word "deliverance" was struck, "which, originating from the world of Christian ideas, would evoke negative feelings against the law." ${ }^{329}$ The wording of article 2 also came from Lenz. He had rejected the original term of "abnormal disposition" as "too indefinite and vague." In some cases it was

\footnotetext{
${ }^{325}$ Cf. Meinungsäußerungen zum Gesetz, BArch. Berlin, R 96 I/2, pp. 126.659-126.690, here: pp. 126.662 (as a facsimile, also in: Roth/Aly, "Gesetz über Sterbehilfe", pp. 140-172, here: p. 143).

${ }^{326}$ Ibid., p. 126.663. Formulation proposal by Ernst Wentzler, in square brackets: formulation proposal by Lenz. Wentzler's version read: "who long for deliverance because of an incurable disease."

${ }^{327}$ Ibid., p. 126.666. Formulation proposal by Lenz, in square brackets: formulation proposal by Kurt Pohlisch, in Lenz's version there is an omission here.

${ }^{328}$ Ibid., p. 126.668. Formulation proposal by Lenz.

${ }^{329}$ Ibid., p. 126.663.
} 
"not at all clear whether abnormal genes or external damage was the basis"; "idiotic or seriously deformed children" 330 would thus not be included by the concept of abnormal disposition - for these, moreover, "a special legal determination was required." ${ }_{331}$ Therefore Lenz pled for restricting the law only to the mentally ill for the time being. Presumably with a view to Heydrich and his interests, Lenz added that one would also have to define expressly "that criminal psychopathy is a mental illness in the sense of the law." ${ }^{332}$ Lenz did not want to make exceptions, but he held the inclusion of "senility of the mind" 333 to be unsuitable. All in all the impression arises that Lenz was one of the driving forces in the discussion and that he left his mark on the draft law. Repeatedly he pushed for precise specifications - in the interest of legal certainty. It was also due to this interest that Lenz wanted to make sure that the law would be applied initially only to cases of serious mental disease, whereby he urged a regulation of "early euthanasia" at a later point in time. That it was by no means his concern to check the "euthanasia" program in progress is apparent in the fact that he was ready to include the "criminal psychopaths" in the sense of the "Community Alien Law" planned by Heydrich.

In the end the draft law discussed remained nothing more than paper. Hitler rejected a legal enclosure for the "annihilation of life unworthy of life." "Euthanasia" continued to proceed in the unlawful cavity of the National Socialist "prerogative state," flanked by an ambitious program of genetic psychiatry and genetic pathology research. In one case the KWI-A, too, profited from the unfettered access to human subjects in sanatoriums and hospitals.

\subsubsection{Nachtsheim and the Low-pressure Experiments on Epileptic Children}

Back in 1940 Hans Nachtsheim, as mentioned above, had performed a large-scale series of experiments on almost 600 rabbits of different races, both from the "epilectic" and the "non-epileptic" breeds, in which convulsions were induced through cardiazol injection to check their compulsion-readiness. As explained, the point was first to theoretically illuminate "the connections between convulsion-readiness and genotype." The series of experiments also pursued a second, entirely practical purpose, however: they were supposed "to provide a contribution to the question so debated in psychiatry, as to whether a genuine epileptic responds to a lower dose of cardiazol with convulsions than does a symptomatic epileptic or a non-epileptic, and thus whether inducing convulsions by cardiazol is of value for differential diagnostics." In this respect the experiments ended in failure. It became apparent that the convulsion-readiness of the rabbits was dependent on their age: Young rabbits

\footnotetext{
${ }^{330}$ Ibid., p. 126.668 .

${ }^{331}$ Ibid., p. 126.673.

${ }^{332}$ Ibid., p. 126.668.

${ }^{333}$ Ibid., p. 126.688
} 
convulsed at a lower dose of cardiazol than older animals; convulsion-readiness in response to cardiazol thus, appeared to diminish with increasing age. This alone would not have debased cardiazol convulsions as a differential diagnostic instrument, as the rabbits of the purely bred "epilectic strain" reacted more sensitively to cardiozol at all ages than did other rabbits. However, at the same time it turned out that the convulsion-readiness of the "epileptic" rabbits was subject to frequently occurring, strong individual oscillations, so that the animals sometimes did not respond to a high dosage - at which even a high percentage of "non-epileptic" animals convulsed, and at other times convulsed even at low doses that would never have triggered convulsions in "non-epileptic animals." In view of these findings Nachtsheim had to admit that cardiazol convulsions possessed "only limited differential diagnostic value." 334

Although the hope for a direct practical use of the convulsion experiments had not been fulfilled, Nachtsheim continued to grant high priority to his research on the "epileptic" Vienna Whites even after starting at the KWI-A on January 1, 1941. From this point on the research projects on epilepsy pursued modified research questions: The direct perspective on differential diagnostics was abandoned, and epilepsy research oriented instead entirely toward the paradigm of phenogenetics. What appeared as a mere disruptive factor in the experimental arrangement under the aspect of differential diagnostics - the modifying influence of age, time of year and season on the convulsion-readiness of the rabbits-, became the actual object of research when embedded in the paradigm of phenogenetics, for apparently the convulsion-readiness of the experimental animals was the result of an interplay among genetic and peristatic factors, which intertwined to cause, enable and induce. If research succeeded in exposing the complex reciprocal actions of genetic disposition, maturation, and environment, science would be much closer to illuminating the process of the pathogenesis of epilepsy.

In his activity report about the 1941/42 fiscal year, Eugen Fischer quite skillfully referred to Nachtsheim's "investigations about the epilepsy of rabbits, which corresponds completely to that of humans." The experiments "to use cardiazol to induce epileptic convulsions like those in humans" were "in full swing," and promised "a more precise analysis of the genetic and non-genetic conditions of the convulsion-readiness of vessels in the brain." 335 Here Fischer did imply that the studies in progress could contribute to the demarcation between genuine and symptomatic epilepsy, yet he painstakingly avoided the term "differential diagnostics," selecting a more open formulation. On the other hand, he left no doubt as to the applicability of the animal model.

However, Nachtsheim had to struggle with some exceptions voiced from the ranks of his critics on precisely this point. Concerns, such as the fact that the structures

\footnotetext{
${ }^{334}$ Nachtsheim, Bericht über die im Jahre 1940 mit Unterstützung des Reichsforschungsrates durchgeführten Untersuchungen zur vergleichenden Erbpathologie, 14/1/1941, pp. 2 f., BArch. Koblenz, R 73/13.328. Cf. Nachtsheim, Krampfbereitschaft und Genotypus I-III.

${ }^{335}$ Fischer, Tätigkeitsbericht über das Geschäftsjahr 1941/42, MPG Archive, Dept. I, Rep. 3, No. 19.
} 
of the human and rabbit nervous systems were too different for the findings obtained with rabbits to be applied to humans without further ado, were forestalled by Nachtsheim himself, who raised the conjecture that the pathological processes which also occurred in humans might possibly be better studied on rabbits, because in the rabbit the convulsion takes place in a much more primitive form, "without all of the accessory parts that have accrued in humans," 336 - an argument based on an abridged mechanistic concept of the organism, which was not terribly solid. After brashly asserting the applicability of the animal model at the outset, over the course of time he sought refuge in more careful formulations:

In this we are certainly aware that a result in an animal experiment can be translated to humans only with caution, especially when the substrates in question are as different as the rabbit brain and the human brain. However, a result for rabbits can be regarded as at least pointing the way to the conditions in humans. ${ }^{337}$

Nachtsheim also had to struggle with the clinicians' critical pointer to the polymorphy of the various clinical pictures subsumed under the concept of epilepsy. He thus toned down his pretense of using the animal model to explain the epilepsy of humans and hence aspired only to relate "rabbit epilepsy to a certain 'variety' of human epilepsy." 338

The most serious was the objection of leading psychiatrists that cardiazol convulsions in rabbits were not comparable to spontaneous convulsions in humans this critique was aimed straight at the experimental arrangement, which made the animal model organism available for human genetic research. Nachtsheim and his staff therefore, also tested other possibilities such as insulin and acetylcholine shock as well as electric spasms. In the course of these tests they concluded that the convulsions in Vienna White rabbits artificially triggered by cardiazol most closely approximated the spontaneous convulsions of the human epilepsy victim.

According to the concept of convulsion-readiness, every human could suffer convulsions - in the case of epilepsy Nachtsheim imagined the boundaries between health and illness to be fluid. Epileptics were different from other humans, he presumed, in that their convulsion threshold was significantly lower. Now, under the banner of higher Mendelism, this was no longer simply regarded as genetic, but rather - in terms of phenogenetics - as the result of a causal chain, the first cause of which is to be sought in the genotype, but which was also influenced by factors in the internal and external milieu. When an organism in a condition of heightened convulsion-readiness was subjected to an adequate environmental stimulus, this would trigger a convulsion - the epilepsy became manifested clinically. The point of Nachtsheim's experiments was thus to manipulate the convulsion-readiness of

\footnotetext{
${ }^{336}$ Nachtsheim, Krampfbereitschaft und Genotypus III, p. 60.

${ }^{337}$ Ruhenstroth-Bauer/Nachtsheim, Bedeutung des Sauerstoffmangels, p. 18. No qualification in Nachtsheim, Modelle menschlicher Erbleiden.

${ }^{338}$ Nachtsheim, Krampfbereitschaft und Genotypus II, p. 242. Cf. also Nachtsheim to Koch, 7/8/1944, MPG Archive, Dept. I, Rep. 3, No. 1: "What you write about the different types of fits in humans corresponds entirely with my opinion. 'Epilepsy' is a collective term, and it would be urgently required that a systematic order be brought into this area."
} 
his rabbits by changing the intervening peristatic variables that modified the effect of the gene. The comparison of young and mature animals was an obvious choice for the first series of tests, as Nachtsheim believed he had determined in his cardiazol experiments, performed to resolve the differential diagnostic problem, that the convulsion-readiness was dependent on age. Therefore, in a paper for the Zeitschrift für Altersforschung in 1941 Nachtsheim reevaluated his previous experimental results under this aspect, and in so doing also introduced them into the still young discipline of geriatrics. ${ }^{339}$ In the field of psychiatric research it was controversial at what point in time and in what form the various types of epilepsies became manifest, whether the clinical picture changed over the course of life, and whether such age differences occurred only in symptomatic epilepsy or in genuine epilepsy as well. Nachtsheim wanted to attempt to pursue these questions using a comparative experimental system on the animal model.

In summer 1942 an epidemic raged among Nachtsheim's experimental animals and forced him to temporarily suspend the experiments on epilepsy, ${ }^{340}$ because the stocks had to recover before this form of "consumptive research" could be continued - in the artificially provoked convulsions, especially when cardiazol was used, it was not seldom for the experimental animals to suffer broken bones or collapse. ${ }^{341}$ When Nachtsheim resumed the experiments in early 1943, he changed the method. He no longer resorted to cardiazol, which had the disadvantage in Nachtsheim's view that its toxic effect was superposed upon the convulsion events and made their observation more difficult. ${ }^{342}$ Therefore, it must have been easy for him to give up this method, especially since cardiazol was difficult to obtain during the war as it was urgently needed for therapeutic purposes. The electric spasm attempts conceived as an alternative to the cardiazol experiments in 1942 had "not proceeded beyond certain preliminary tests," 343 not least because the "convulsator" by the Siemens-Reiniger plant procured in 1941 proved unsuitable for animal testing. ${ }^{344} \mathrm{~A}$

\footnotetext{
${ }^{339}$ Nachtsheim, Krampfbereitschaft und Lebensalter. Cf. in general: Hahn, Altersforschung.

${ }^{340}$ Nachtsheim, Bericht über die im Jahre 1942 mit Unterstützung des Reichsforschungsrates durchgeführten Untersuchungen zur vergleichenden und experimentellen Erbpathologie, 22/3/1943, BArch. Koblenz, R 73/15.342, pp. 99-112 (incorrect pagination), here: p. 99.

${ }^{341}$ Nachtsheim, Bericht über die im Jahre 1941 mit Unterstützung des Reichsforschungsrates durchgeführten Untersuchungen zur vergleichenden und experimentellen Erbpathologie, 27/3/1942, BArch. Koblenz, R 73/13.328.

${ }^{342} \mathrm{~A}$ further practical disadvantage was that repeated injection of cardiazol destroyed the veins. Nachtsheim, Bericht über die im Jahre 1940 mit Unterstützung des Reichsforschungsrates durchgeführten Untersuchungen zur vergleichenden und experimentellen Erbpathologie, 14/1/1941, p. 4, ibid.

${ }^{343}$ Nachtsheim, Bericht über die im Jahre 1942 mit Unterstützung des Reichsforschungsrates durchgeführten Untersuchungen zur vergleichenden und experimentellen Erbpathologie, 22/3/1943, BArch. Koblenz, R 73/15.342, pp. 99-112, here: p. 112.

${ }^{344}$ In October/November 1942 this convulsator was loaned out to the "Waldhaus Berlin-Nikolassee" Clinic for Psychiatric and Emotionally Disturbed Patients, an institution that belonged to the Inner Mission of the Protestant church. In return, Nachtsheim received from the clinic a convulsator of Swiss manufacture, which, despite expectations, proved to be just as unsuitable. The trade was then reversed. Cf. on this the correspondence in BArch. Koblenz, R 73/13.328.
} 
change in the experimental arrangement was thus essential, and this led Nachtsheim to high altitude medicine.

Crucial for the further development was the incipient collaboration between Hans Nachtsheim and Gerhard Ruhenstroth-Bauer (1913-2004). ${ }^{345}$ After completing his studies of physics, in September 1939 Ruhenstroth-Bauer had come to Adolf Butenandt at the KWI for Biochemistry to write a dissertation in the area of hormone chemistry. When this dissertation project hit a snag due to the war, Ruhenstroth-Bauer turned to research on the regeneration of red blood cells (hemopoiesis). He had been forced to interrupt this research when he was drafted into the Luftwaffe as a military physician and sent to the Eastern Front. Butenandt lobbied Erich Hippke (1888-1969), ${ }^{346}$ head of the Luftwaffe Medical Corps, to have Ruhenstroth-Bauer reassigned to Berlin, and Hippke - it is not clear whether upon Butenandt's urging or on his own initiative - ordered the young military physician to Berlin in June 1942, in order to perform special research on hemopoiesis. Ruhenstroth-Bauer was searching for a substance that was capable of effecting a prolonged propagation of the red blood cells (erythrocytes) - he assumed that it would be a hormone, which he intended to name hemopoietin. The potential military importance of the project for air warfare was obvious: pilots who were injected with the blood-enriching substance before takeoff would be able to fly at higher altitudes in air with less oxygen, without any decrease in performance. In a series of preliminary tests, Ruhenstroth-Bauer endeavored to research the process of generating blood cells in various experimental animals in different test arrangements, and in so doing also experimented with oxygen deficiencies and low air pressure. At this point the research interests of Ruhenstroth-Bauer and Nachtsheim overlapped. Convulsions are a characteristic symptom of altitude sickness - RuhenstrothBauer's research practice was oriented around raising the threshold for altitude convulsions by increasing the number of red blood cells. For its part, epilepsy research was close to altitude research because oxygen deprivation had long been discussed as a possible trigger for epileptic convulsions. The possibilities of high altitude medicine to generate oxygen deprivation experimentally in vacuum chambers thus also opened up new ways for Nachtsheim to move his experiments with the "epilectic" Vienna Whites forward. Nachtsheim was interested in collaborating with Ruhenstroth-Bauer because the latter experimented with rabbits deprived of oxygen, was well familiar with the physiology of blood and respiration and brought along biochemical expertise. For Ruhenstroth-Bauer's part, Nachtsheim's research on the phenogenetics of convulsion-readiness must have been of fundamental importance - and added to this was the fact that Nachtsheim developed an interest in blood and hemopoiesis starting around mid-1942.

The initiative for collaboration probably came from Hans Nachtsheim, although it can be presumed that the two men were already acquainted due to the tight net of

\footnotetext{
${ }^{345}$ For a biography: Schwerin, Experimentalisierung, pp. 389-392; Klee, Personenlexikon, p. 514. As a physician of the Luftwaffe Ruhenstroth-Bauer had performed clinical experiments on "48 Russian edema patients" (Soviet prisoners of war). Schwerin, Experimentalisierung, pp. 302f. (note 91).

${ }^{346}$ For a biography: Klee, Personenlexikon, p. 258.
} 
contacts between the Kaiser Wilhelm Institutes. Ruhenstroth-Bauer had contacted Hubertus Strughold (1898-1986), ${ }^{347}$ the head of the Reich Ministry of Aviation's Research Institute for Aeronautical Medicine (Luftfahrtmedizinisches Forschungsinstitut des Reichsluftfahrtministeriums), for assistance in conducting the low-pressure experiments involved in his hemopoietis project. Nachtsheim, too, through his former doctoral student Harry Suchalla, who had found a position on the "top floor" of the institute, ${ }^{348}$ had contacts to Strughold, whose institute, which was housed in the Military Physicians' Academy (Militärärztliche Akademie) along the bank of the Spandauer Schiffahrtskanal on Scharnhorststrasse in Berlin, had several vacuum chambers at its disposal. Around June 1943 Nachtsheim and Ruhenstroth-Bauer began with their rabbit experiments in the vaccum chamber of the Research Institute for Aeronautical Medicine.

Yet these low-pressure experiments constituted only a small portion of the around 150 experiments that Nachtsheim and Ruhenstroth-Bauer performed in 1943, with support from the Reich Research Council and the third-highest priority rating of " $S$," for the purpose of depriving their test subjects of oxygen in various ways. The two scientists advanced a concise justification for their experimental program:

The results of the cardiazol experiments on epileptic and non-epileptic rabbits in previous years made it seem desirable to investigate the importance of oxygen deprivation for the inducement of the epileptic attack in special experiments on young and mature animals. ${ }^{349}$

Through the experiments in the vacuum chamber Nachtsheim saw his view confirmed that convulsion-readiness depended on age. "Normal mature animals" subjected to oxygen deprivation in the vacuum chamber, which corresponded to a height of 4,000-7,000 m, showed no reaction at all, and this was also the case for "normal young animals" and "mature epileptic animals." In contrast, "young epileptic animals aged 2-3 months" nearly always suffered at least a rudimentary epileptic attack under these conditions, and in cases of a "generalized attack with all phases of spontaneous convulsions" the frequent result was "the sudden death of the animals." 350

Further series of tests "proved" to Nachtsheim that it was the oxygen deprivation ensuing from the low pressure that induced the convulsions: for one, the same result could also be attained when the test subjects were subjected not to low pressure, but to a mixed nitrogen-oxygen atmosphere that corresponded to a height of around 7,000 $\mathrm{m}$. Second, it turned out that an epileptic attack could also be induced in the rabbits by interrupting the flow of blood to the brain, again, particularly "promptly and impressively" in the "young epileptic animals."

\footnotetext{
${ }^{347}$ For a biography: ibid., p. 610.

${ }^{348}$ Schwerin, Experimentalisierung, pp. 300, 312.

${ }^{349}$ Nachtsheim, Bericht über die im Jahre 1943 mit Unterstützung des Reichsforschungsrates durchgeführten Untersuchungen zur vergleichenden und experimentellen Erbpathologie, 21/9/1943, BArch. Koblenz, R 73/15.342, pp. 71-75, here: p. 71.

${ }^{350}$ Ibid., p. $71 \mathrm{f}$.
} 
For a more precise analysis of the effect of oxygen deprivation, in further tests the rabbits were "set in part into a proconvulsant, in part into an anticonvulsant condition." So some animals were tested in the condition of alkalosis or acidosis (shift in the acid-base balance in the blood toward the alkaloid or acidic side, respectively). Others were placed in a mixture of air and carbonic acid, or treated with bromural, luminal, or caffeine before the oxygen deprivation test. It proceeded from all tests, Nachtsheim proclaimed, "that in the epileptic rabbit oxygen deprivation is the root cause for the inducement of the epileptic attack." The term "myoclonic threshold" is largely identical to the term "sensitivity to oxygen deprivation of the brain cells inducing the attack." 351

This very assertion was disputed from an influential quarter. A group of scientists around Alois Kornmüller (1905-1968), ${ }^{352}$ Director of the Department for the Experimental Physiology of the Brain at the KWI for Brain Research, had been studying epilepsy for a long time - also in collaboration with Strughold - and was already looking into the connections between epilepsy and altitude sickness. The junior physician J. Gremmler, who belonged to the "Brain Research Office of the Air Force" (Gehirnforschungsstelle der Luftwaffe) under Hugo Spatz, performed a series of experiments in which (adult) epileptic patients from sanatoriums and hospitals were experimentally put into a condition of hypoxemia and then their brain waves measured. This experiment brought Gremmler to the conclusion that oxygen deprivation must be excluded as the trigger for epileptiform convulsion fits. ${ }^{353}$ This result constituted a double challenge to Nachtsheim: not only were Gremmler's findings on the importance of oxygen deprivation diametrically opposed to his own, but Gremmler also cast doubt as to whether the convulsions in altitude sickness could be equated with the epileptic attack at all. In so doing, he also questioned the very foundations of the animal model developed by Nachtsheim and Ruhenstroth-Bauer, for if the convulsions generated in rabbits by low pressure were not epileptiform, then the results on varying convulsion thresholds in young and mature animals could not be translated to human epileptics. Unless Nachtsheim and Ruhenstroth-Bauer wanted to call Gremmler's findings into question in principle and they did not, because they saw nothing objectionable in the experiments - there was only one way for them "to salvage" their own research findings:

Elsewhere it has been proved for humans that adult epileptics do not respond to oxygen deprivation with an attack. Since a significant difference in the behavior of mature and young epileptics was yielded in our animal experiments, we tested epileptic children at low pressure in a similar manner. ${ }^{354}$

\footnotetext{
${ }^{351}$ Ibid., p. 72.

${ }^{352}$ For a biography: Klee, Personenlexikon, p. 332.

${ }^{353}$ Gremmler, Beziehungen.

${ }^{354}$ Nachtsheim, Bericht über die im Jahre 1943 im Auftrage des Reichsforschungsrates durchgeführten Untersuchungen zur vergleichenden und experimentellen Erbpathologie, 21/9/1943, BArch. Koblenz, R 73/15.342, pp. 71-75, here: p. 73. Cf. also Ruhenstroth-Bauer/Nachtsheim, Bedeutung des Sauerstoffmangels, p. 20: "The characteristic difference in the behavior of young
} 
If they were successful in inducing epileptic attacks in epileptic children through low pressure, Gremmler's negative findings would be relativized - in Gremmler's experimental arrangement, it could be argued, the oxygen deprivation was simply not great enough to induce a convulsive attack in the adult test subjects - and the hypothesis of oxygen deprivation as the trigger of the epileptic attack would be saved. Beyond this, if the epileptic children reacted to low pressure in the same way as the young epileptic rabbits, this would furnish impressive evidence of the animal model's applicability. Paradoxically, in this case the human experiment was to function as the confirmation for the animal experiment, which was originally conceived of as a substitute for human experiments.

There are only two written sources on the further course of events, both of them quite meager - a report by Nachtsheim to the Reich Research Council of September 21, 1943 or March 15, 1944, respectively, and a short letter from Nachtsheim to Gerhard Koch of September 20, 1943 - as well as several testimonials put down in writing by Gerhard Ruhenstroth-Bauer at great intervals of time. These sources document without a doubt that at least one such human experiment took place. However, we know hardly anything about how this experiment came about and how it proceeded in detail. For the present we also remain in the dark about what happened to the human "guinea pigs" later and whether further experiments of this kind followed.

Apparently Nachtsheim, in his search for epileptic children for the planned tests, turned to Gerhard Koch, who was convalescing in Berlin from June to August 1943 and worked as a guest scholar at the KWI-A during this period. At the time Koch's research included work on "residual epilepsy." As he wrote in his memoirs, he and Nachtsheim "repeatedly [conducted] instructive and useful conversations about the etiology and heritability of the various epileptic convulsive conditions in humans and animals and about the convulsion-readiness behind these conditions which is so different for each individual." ${ }^{355}$ It was presumably Koch who drew Nachtsheim's attention to the Berlin-Wuhlgarten Sanatorium and Hospital (Heil- und Pflegeanstalt Berlin-Wuhlgarten), in which a large number of epileptics were housed. Koch had worked there from 1937 to 1939 on "family studies" in the context of his dissertation about Sturge-Weber disease (today: Sturge-Weber-Krabbe syndrome). He had maintained contact afterward - as late as 1943 Julius Hallervorden sent Koch the pathological report of a test subject who died after the family study was concluded. ${ }^{356}$ While still working in Dahlem in summer 1943, Koch, assisted by Hans Grebe and

and mature epileptic animals in response to oxygen deprivation made it appear desirable to investigate on humans a comparison of young and adult epileptics. Gremmler investigated only adults, and was not successful in inducing an epileptic attack in them through hypoxemia. After conclusion of our own studies of young epileptics, which are also interesting to the clinic, we intend to report about the detailed results." - On the human experiment described in the followiing, cf. Müller-Hill, Genetics after Auschwitz; Deichmann, Biologen, pp. 308-314; idem., Hans Nachtsheim, pp. 146-148; Koch, Humangenetik, pp.120-148; Knaape, Medizinische Forschung, p. 227; Klee, Auschwitz, pp. 228-230; Proctor, Adolf Butenandt, pp. 18-20; on the basics, see the recent work: Schwerin, Experimentalisierung, pp. 302-319.

${ }^{355}$ Koch, Humangenetik, p. 103.

${ }^{356}$ Schwerin, Experimentalisierung, p. 308 (note 115). 
the photographer of the KWI-A, Ingeborg Hellhoff, produced photographs of the patient with Sturge-Weber disease who had been the point of departure for his genealogical studies over the course of his dissertation. ${ }^{357}$ On September 20, 1943 Nachtsheim informed Koch, who had since moved on to Neubrandenburg:

\begin{abstract}
Dr. Ruhenstroth had, in the meantime, already established contact with Wuhlgarten and learned that only adult epileptics are there. He was referred from Wuhlgarten to Görden, and from there, through the kindness of Senior Medical Councilor Dr. [Karl] Brockhausen [ $\left.{ }^{*} 1890\right]$, received 6 epileptic children (4 genuine, 2 symptomatic epileptics), with whom we did experiments last Friday [September 17, 1943] in Prof. Strugholt's [sic] vacuum chamber. Yet the tests came out just as negative as those Gremmler performed on adult epileptics. But at the moment it is not possible to say that rabbits and humans respond differently to low pressure, for the children we tested were aged 11-13, which corresponds to a rabbit aged 5-6 months. However, epileptic rabbits of 5-6 months do not show the reaction-readiness of 2-3-month-old animals, which nearly always had attacks. We would have to be able to test epileptic children of 5-6 years of age, but this is not possible at the moment because this age group is not present at Görden. ${ }^{358}$
\end{abstract}

So from Wuhlgarten, Ruhenstroth-Bauer and Nachtsheim had been referred to the State Institute in Brandenburg-Görden directed by Hans Heinze, which played an important role in the Nazi "euthanasia" program. It remains unclear who ultimately established contact with Görden. In the 1990s Ruhenstroth-Bauer claimed that Nachtsheim had enjoyed good contacts to Görden and was involved in the treatment of epileptic children there, so that he addressed the children by their first names and elucidated their anamneses, ${ }^{359}$ while he - Ruhenstroth-Bauer - met the children for the first time in the vacuum chamber on September 17, 1943, had never seen them before and did not even know where they came from. Considering the letter from Nachtsheim to Koch, there is certainly reason to regard this testimony as an attempt at self-justification, but it is indeed conceivable that Nachtsheim had been in contact with Görden for some time previously. This could have come about via the KWI for Brain Research, which was, for its part, linked closely with Görden through Julius Hallervorden, who was both Director of the Department for Histopathology at the KWI for Brain Research and Prosector of the Brandenburg State Psychiatric Institutes from 1938 onward - in fact the Department of Pathology located in Görden from 1938 had been officially transferred to the KWI for Brain Research in Berlin-Buch, and the laboratory in Görden was run as an outpost of the KWI. Through the department of pathology in Görden and other channels, over 700 brains of "euthanasia" victims made their way to the KWI for Brain Research, where they were subjected to pathological examination by Julius Hallervorden and Hugo Spatz. Nachtsheim had good contacts to the KWI for Brain Research - for years he had sent his rabbits from the epilepsy experiments to Gerd Peters (19061987) for postmortem examination. As mentioned above, Nachtsheim also had

\footnotetext{
${ }^{357}$ Koch, Humangenetik, pp. 101, 104.

${ }^{358}$ Nachtsheim to Koch, 20/9/1943, printed as a facsimile in: Koch, Humangenetik, pp. 125 f., quote: p. 125 (original emphases).

${ }^{359}$ Schwerin, Experimentalisierung, p. 307 (note 111).
} 
close contact with the pathologist Hans Klein, who performed postmortem examinations on rabbits with dropsy for him starting in 1943, but also participated in the autopsies of the victims of the "Special Children's Department" at Wiesengrund. What should not be forgotten is that Fritz Lenz was familiar with a number of physicians from the staff of the "euthanasia" program from his consulting activities on the draft law for euthanasia, including Hans Heinze. Pointing out these entanglements is important to the extent that it can be presumed with a high degree of security that Nachtsheim was aware of the "euthanasia" program still in progress.

As the available sources testify unanimously, the experiment did not produce any tangible result - it did not succeed in inducing an epileptic fit in the children through low pressure. Consequently it did not cause them any suffering - but Ruhenstroth-Bauer and Nachtsheim could not have foreseen this. According to Nachtsheim's account, the children were subjected to a low-pressure situation that corresponded to an altitude of $6,000 \mathrm{~m}$ (not to mention the mental strain of being locked into the vacuum chamber). According to the knowledge available to altitude medicine at the time, at this altitude the onset of threatening conditions had to be expected even for adults - all the more so for children. Moreover, there was no possibility of resorting to any previous experience with epileptic humans in lowpressure situations. Furthermore, Ruhenstroth-Bauer and Nachtsheim knew from the animal experiments that young epileptic rabbits reacted to low pressure with violent, often fatal convulsions - and they expected (and hoped!) that the children would react like the rabbits. In other words: the scientists knowingly accepted the risk that the children could be placed in fatal danger. Ruhenstroth-Bauer's reassuring statement that he himself, Nachtsheim and an additional physician of the Luftwaffe had been in the vacuum chamber with the children and had been able to abort the experiment at any time - as could the children themselves - thus fails to get at the root of the matter.

There is no doubt that Ruhenstroth-Bauer and Nachtsheim planned further tests with younger children after the failed first experiment. Whether these came about cannot be determined with any certainty. However, it is probable that it was no longer possible to realize these tests. Of the six children in the first experiment, there is proof for only one having survived the Third Reich; ${ }^{360}$ the fate of the other children must remain an open question. Perhaps they fell into the gears of the "euthanasia" program - in contrast to the clinical examinations and tests in the two "research departments" of the "euthanasia" apparatus in Brandenburg-Görden and Wiesloch/Heidelberg, however, it went against the logic of the experiment to kill the children and examine them pathologically as long as they had not suffered an epileptic attack.

Nonetheless: the low-pressure experiments by Nachtsheim and RuhenstrothBauer ignored the Reich Health Council's regulations on human experiments from the year 1931 as a matter of course. For the most part, these regulations, as adduced elsewhere, had already been ignored by research back in the 1930s. Yet this experiment

${ }^{360}$ Knaape, Medizinische Forschung. 
marked a further boundary crossing, as the experimenters unscrupulously subjected the children to an incalculable health risk, even accepting a potentially fatal outcome of the test - and all of this needlessly, for the utilization of the vacuum chamber was by no means imperative. Oxygen deprivation could have been effected in other ways, especially as Gremmler, upon whose work the experiment was based, had not worked with low pressure. Apparently the standards of scientific ethics had shifted further. A comment with which Nachtsheim and Ruhenstroth-Bauer preceded their short report about the low-pressure experiments on rabbits implied as much:

For the clinician working on patients experimentally, the possibilities are always restricted, for he has to take the welfare of his patients into consideration. Only in exceptional cases will a researcher dare to perform an experiment on a patient in the interest of future patients, the outcome of which cannot be predicted with any certainty. Here a method assists the field of medicine, which allows these difficulties to be circumvented at least for a few genetic illnesses, the model experiment on animals. ${ }^{361}$

Alexander von Schwerin is correct to emphasize that this opens up a new moral dimension. While up to this point Nachtsheim had designated the human experiment as morally inadmissable without restriction, and recommended the animal experiment as a morally unobjectionable alternative, he now no longer categorically excluded the possibility of research on humans for the benefit of others, even if the outcome was uncertain. In this case human and animal experiments no longer appear as mutually exclusive alternatives; on the contrary, it suggests a complementary relationship. Schwerin lists a number of factors that contributed to the erosion of the ethical standards of science: the objectifying linguistic usage, which not only blurred the boundaries between humans and animals (Nachtsheim, for instance, referred to both as simply "epileptics") and transformed both into "material," but also elevated the "genotype epilepsy," detached from the human patient, to the actual scientific object; and also the "militarization" of altitude research. ${ }^{362}$ Two other aspects deserve special emphasis: First it must be kept in mind that the newly developed coma and shock therapies (insulin coma treatment, cardiazol convulsion treatment, and electric shock therapy in the first years of World War II) had been widely adopted in German institutional psychiatry since the mid-1930s, although these "heroic therapies" put the patients in horrible states of anxiety, often inflicted serious injury to their health, and in some cases even resulted in their deaths. Therapeutic ambition was willing to accept high risks ${ }^{363}-$ thus, it is no wonder that artificially inducing convulsive fits in epilepsy research was not questioned. Second it must be considered that by 1943, somewhere around 100,000 mentally ill, epileptic, or mentally disabled patients from the sanatoriums and hospitals of the German Reich already had been murdered in the course of "euthanasia" - and thousands of infants, children, and teenagers had also been killed in the course of the children's "euthanasia," the "Aktion T4" and "decentral euthanasia"

\footnotetext{
${ }^{361}$ Ruhenstroth-Bauer/Nachtsheim, Bedeutung des Sauerstoffmangels, p. 18 (original emphasis).

${ }^{362}$ Schwerin, Experimentalisierung, pp. 312f., $318 \mathrm{f}$.

${ }^{363} \mathrm{Cf}$. Kersting/Schmuhl, Einleitung, pp. $37 \mathrm{f}$.
} 
since August 1941. This undermined the moral status of the children from Görden. Now they were little more than readily available, not terribly valuable "material" for "consumptive research."

\subsection{5 "The Problems of White Africa": Colonial Science Ambitions}

With the entry of the German Reich into the circle of colonial powers, German anthropology and ethnology - like the other sciences - felt challenged to make their knowledge useful for the justification and legitimation, execution, and consolidation of colonial rule. A relationship of mutual engagement emerged: The sciences aligned themelves with colonial interests in their selection of subjects and objects, their theoretical and methodological approaches, and made the knowledge thus obtained available to the colonial administration. In return, the colonial state furnished the colonially oriented scientific disciplines and subdisciplines with financial resources, granted them privileged status in the institutional structures and raised their value in the public. Colonial interest groups mediated between state and science. "In this system of mutual obligations between state, political parties, interest associations, and sciences after 1885, a spectrum of new areas of knowledge developed in the German science landscape, which was known as the 'colonial sciences' in the contemporary diction [...]." 364

Fischer's study on the "Bastards of Rehoboth" of the year 1913 was conceived and intended as a contribution to colonial science, apparent in the fact that the author drew practical consequences for colonial policy from his research findings in its concluding chapter, Die politische Bedeutung der Bastards ("The Political Importance of the Bastards"). Despite his heterosis thesis, according to which a "population of bastards" is located between the "source races" as regarded their physical, mental, and intellectual characteristics, he took a clear position on the ban on mixed marriages in the colonies so hotly debated at the time:

Every European nation without exception [...] that has assimilated the blood of inferior races

- and that Negroes, Hottentots and many others are inferior can be denied only by dreamers

- has paid for this assimilation of inferior elements with intellectual, cultural decline.

At the end of his colonial policy conclusions, Fischer designed a system of apartheid for German Southwest Africa, long before such a system was introduced in South Africa: The Ovambo and Herero were to be deployed as agricultural laborers, the Hottentots as herders. The "bastards of Rehoboth," in contrast, were assigned an important function as a privileged intermediate class, "as native craftsmen and manual laborers [...], as policemen, i.e. minor officers, foremen, and leaders of the entire supply lines and vehicle pool of the government, troops and

${ }^{364}$ Grosse, Kolonialismus, p. 35. 
private persons, in part as small farmers in their bastard country, to which everyone returns after serving their time." Despite his paternalistic attitude toward the "little nation of bastards," Fischer regarded the Rehoboths from the perspective of the colonial masters:

So they will be granted just that degree of protection which they need as a race inferior to us, in order to endure, no more and only as long as they are useful to us - otherwise free competition, i.e. in my opinion, here downfall! $!^{365}$

This last comment by Fischer reads like a retrospective justification of the war of extermination the German colonial troops had led against the rebellious Herero and Nama from 1904 to $1908 .{ }^{366}$ Fischer had profited from this genocide directly, for he apparently brought skulls and skeletons of "Hottentots" with him from Southwest Africa, ${ }^{367}$ which may have come from the internment camps on Shark Island, where people died like flies. ${ }^{368}$ The skeleton of the Nama leader Cornelius Frederiks ( ${ }^{\dagger}$ 1907) also supposedly came into Fischer's collection in this way. ${ }^{369}$

As mentioned above, Fischer continued his studies of the "bastards of Rehoboth" until 1942. ${ }^{370}$ Yet the "bastard studies" by Fischer and his pupils were no longer embedded in a colonial science and colonial policy context, but rather in the concept of anthropobiology: With its particular methodology, which combined anthropometry, genealogy, genetics, and ethnology, they were supposed to bring together anthropology and human genetics. However, "bastard research" had not lost its practical application, as the role of the institute in Dahlem in the sterilization of the "Rhineland bastards" quite impressively evinced.

After World War I the colonial sciences became part of the "colonialism without colonies," which blossomed so lushly in Germany between 1918 and 1943. Colonial research did not simply cease after the loss of the colonies. On the contrary, in view of a future German colonial empire, it was even intensified. Until the German defeat in Stalingrad, when colonial planning was officially discontinued, a perfect colonial empire had been designed on the drawing board. "One can only ask with astonishment," in the words of Wolfe W. Schmokel, "whether at any point in history a non-existent empire had ever been so well administered [...]." ${ }^{371}$ Increasingly, colonial planning was based on a scientific foundation. Tropical medicine,

\footnotetext{
${ }^{365}$ Fischer, Rehobother Bastards, pp. 302, 305, 302 (original emphases). Cf. also Gessler, Eugen Fischer, pp. 73 f.; Lösch, Rasse, pp. 72-77.

${ }^{366}$ On this, still the best: Drechsler, Südwestafrika.

${ }^{367} \mathrm{Cf}$. Uhlebach, Messungen, p. 449, where the author thanks Eugen Fischer for "material" from his collection. Apparently this collection was destroyed by the bombing of the Freiburg Anatomical Insitute in 1917. In 1921 Fischer addressed the readers of the Deutsche Kolonialzeitung asking them to provide him with material. Cf. Eckart, Medizin, p. 257.

${ }^{368}$ Cf. ibid., pp. $283-290$.

${ }^{369}$ Dierks, Chronologie, pp. 98, 101. It is possible that this is mistake. Cf. Fetzer, Untersuchungen.

${ }^{370}$ On the history of the "bastard studies of Rehoboth" up to Fischer's death, cf. also Schmuhl, "Neue Rehobother Bastardstudien."

${ }^{371}$ Schmokel, Traum, p. 159. On this, now also: Kundrus (ed.), Phantasiereiche.
} 
tropical technology, geography, regional development, demography, anthropology, social hygiene, and eugenics dealt intensively with colonial policy issues.

At this time there is no indication that the KWI-A was included in colonial policy planning in the late 1930s - be it by the Race Policy Office of the NSDAP, which was closely linked with the institute in Dahlem through its director Walter Groß, and which had presented the main features of a future National Socialist race policy in the colonies in 1938 with a tract entitled Kolonialfrage und Rassegedanke ("The Colonial Question and Race Theory"): ${ }^{372}$ The plan was for strict race segregation, a ban on mixed marriages, the restriction of contact between blacks and whites to a minimum, and so on. In an article for the periodical Rassenpolitische Auslandskorrespondenz (Race Policy Foreign Correspondence), Eugen Fischer legitimated such forms of apartheid with reference to "indisputable and provable facts, to the fact that mental attributes are based on genetic dispositions, that race differences are genetic differences, that mental attributes are different for each races, and that there are thus mental differences between races." ${ }^{373}$ Fischer's admonition to investigate such "mental race differences" scientifically and to lay a scientific foundation for race policy fell on deaf ears, however. That the "Law for the Protection of Colonial Blood" drafted by the Colonial Policy Office in 1940 equated the "half-breeds with an admixture of native blood" with the population of color as regarded the ban on mixed marriages ${ }^{374}$ was certainly in accordance with Fischer's wishes, but the notion upon which this passage was based, that the "halfbreed" was under both "source races" in terms of his or her mental and psychic attributes, ${ }^{375}$ stood in blatant opposition to Fischer's theory of heterosis.

In the course of World War II, however, as mentioned above, collaboration developed between the Colonial Policy Office and Gottschaldt's Department for Genetic Psychology. In September 1940 Gottschaldt took on the article about "Psychological Problems and Methods in Colonial Science" for the Afrika Handbuch der angewandten (kolonialen) Völkerkunde (“Africa Manual of Applied (Colonial) Ethnology") 376 contracted by the Colonial Policy Office of Hugo Adolf Bernatzik (1897-1953). The manuscripts were ready for printing in fall 1943, but were destroyed as a result of a bombing, so that the Handbuch der angewandten Völkerkunde could not be published until 1947 - including the article by Gottschaldt along with a "Questionnaire for the Psychological Evaluation of Native Workers" he had developed. ${ }^{377}$

\footnotetext{
${ }^{372}$ Hecht, Kolonialfrage.

${ }^{373}$ Fischer, Geistige Rassenunterschiede, p. 4. In 1936 Fischer felt compelled to protest vehemently in Volk und Rasse, the organ of the National Committee for the National Health Service, against an article by the Catholic theologian Theodor Gentrup (Berlin), who had advocated "racially mixed marriage" in the colonies on the authority of Fischer's work on the "bastards of Rehoboth." Fischer, Frage "Rassenmischehe."

${ }^{374}$ Reprinted in: Kum'a N' Dumbé III, Pläne, p. 179. On the political background: Hildebrand, Reich.

${ }^{375}$ Hecht, Bedeutung, here: No. 11, p. 8.

${ }^{376}$ Byer, Fall Bernatzik, p. 295.

${ }^{377}$ Gottschaldt, Psychologische Probleme in der Kolonialforschung (the questionnaire is on pp. 180-186).
} 
Another, entirely unexpected possibility to reestablish himself in the field of colonial science emerged from one of Fischer's other research interests: his search for the "Cro-Magnon race," whose traces he believed to have discovered back in 1908 upon his return journey from Southwest Africa, and then on a further research trip in 1925 in the population of the Canary Islands, and finally also in the contemporary European "Phalian type." 378 On a research journey to Spanish Morocco, planned for the 1934/35 fiscal year, Fischer apparently had intended to track down the Cro-Magnon type in Northern Africa as well, yet this research plan was delayed indefinitely because of Fischer's heavy workload at the rectorate.

With the formation of the German Africa Corps in January 1941 and the conquest of Cyrenaica in March/April 1941, when the plans for founding a German colonial empire in Northern Africa took on more concrete shape, Cro-Magnon research, little more than a hobbyhorse of Fischer's for so many years, quite surprisingly took on political importance. The virtuosic research strategist Eugen Fischer immediately recognized the emerging possibilities. On May 8, 1941 he lectured to the Prussian Academy of Sciences about "The Problems of White Africa." Proceeding from the term "White Africa," coined by Dominik Josef Wölfel (1888-1963), Fischer claimed that the part of Africa located north of the Sahara, in terms of climate, geology, zoology, and botany, but above all "according to human races and cultures, clearly and fundamentally departs and stands out from the remainder of Africa, from the Africa of the Negroes, from Black Africa." ${ }^{379}$ Fischer presumed that the entire Mediterranean region was settled by a "Mediterranean race," in which shares of other races had been incorporated in the historical era - Arab, Nordic, Alpine, Negroid. Fischer saw one of the roots of the "Mediterranean race" in the prehistoric Cro-Magnon race, which was characterized by "blondness and blue eyes." 380

The line of attack is clear: Through the anthropological-ethnological differentiation between Black and White Africa, Fischer supplied the scientific basis to legitimate pushing forward the borders of the emerging Greater European Empire under the hegemony of National Socialist Germany to the northern edge of the Sahara, without any race policy scruples. It can come as no surprise that Fischer, in return, demanded funds to accelerate the advancement of the scientific exploration of Northern Africa.

Following his lecture, Fischer - along with the Africanist Dietrich Westermann (1875-1956) and the Egyptologist Hermann Grapow (1885-1967) - thus proposed to the Prussian Academy of Sciences the establishment of an interdisciplinary research commission on White Africa. In their proposal the three scholars urged for haste, for "after the war the development of the Sahara areas with automotive and aeronautic routes, and through the construction that has just commenced of a $[\ldots]$ trans-Saharan railway, will certainly restart in full strength, and thus an increasing

\footnotetext{
${ }^{378}$ Cf. also Ritter, Cro-Magnon-Merkmale.

${ }^{379}$ Quoted in Lösch, Rasse, p. 376. Reworked version of the lecture: Fischer, Weißafrika.

${ }^{380}$ Ibid., p. 132.
} 
destruction of the remaining witnesses of the White African past set in." 381 The academy approved the proposal immediately. In 1942/43 Fischer held "soliciting lectures" 382 on the topics surrounding White Africa.

The commission instigated by Fischer had no opportunity to develop any activities of note - Germany's colonial dreams were over too soon. When the commission's three subject groups convened for the first time at the invitation of the Colonial Science Department of the Reich Research Council and the German Research Association on January 27, 1943 - a few days before the defeat in Stalingrad - for a 3-day conference about "Colonial Ethnology, Colonial Linguistic Research and Colonial Race Research" in Leipzig, all of the colonial science plans were already scrap.

The speakers in the "Colonial Race Research" section - besides Otto Reche, Director of the Institute for Race Science and Ethnology at the University of Leipzig, and Egon von Eickstedt (1892-1965), ${ }^{383}$ Director of the Institute for Anthropology at the University of Breslau - were Eugen Fischer and Wolfgang Abel. Based on a reworked version of his lecture for the academy, Fischer outlined the anthropological concept of White Africa once again. Abel dealt with "Race Problems in Sudan and Its Borderlands." This harmless title concealed extremely explosive subject matter. Abel presented numerous photographs of anthropological types from the Sahel zone, most of which depicted French prisoners of war. As Abel mentioned in passing, he had been detailed to the "Inspection of the Personnel Controlling of the Army (Army Psychology)" (Inspektion des Personalprüfwesens des Heeres (Heerespsychologie), to perform series of anthropological examinations of French colonial soldiers in a number of war prison camps. ${ }^{384}$ "Hereby the residents of different areas or different tribes of Sudan were put together in large groups and the number of the persons best rendering the type were always photographed." Thus, "good illustrative material" 385 was created, comprising the photographs of around 350 persons. According to statements made in the 1980s, in the context of this activity Abel was also at a "leper station in Bordeaux" 386 - what was probably meant was the Special Military Hospital for Colonial Medicine in St. Médard near Bordeaux - in order to examine the changes in the pattern of fingerprints caused by the disease. The footprints of "Guinea Negroes" from the Special Military Hospital for Colonial Medicine in Georg Geipel's estate were quite probably taken by Abel. ${ }^{387}$

\footnotetext{
${ }^{381}$ Quoted in Lösch, Rasse, p. 376.

${ }^{382}$ Fischer, Tätigkeitsbericht 1942/43, MPG Archive, Dept. I, Rep. 3, No. 20.

${ }^{383}$ Eickstedt himself was not present in Leipzig, his lecture must have been read by a deputy. Cf. Verschuer to Fischer, 9/2/1943, MPG Archive, Dept. III, Rep. 86 A (Münster), No. 9.

${ }^{384}$ On Hitler's orders, a large portion of the African prisoners of war - around 80,000 men - had been deported to Southern France (Bordeaux). Cf. Klee, Auschwitz, p. 257.

${ }^{385}$ Abel, Rassenprobleme im Sudan, here: p. 144.

${ }^{386}$ In an interview with Benno Müller-Hill, Abel stated that he was "in a leper station in Bordeaux visiting Dr. Weddingen in the tropical medicine military hospital." Müller-Hill, Tödliche Wissenschaft, p. 146.

${ }^{387}$ MPG Archive, Dept. III, Rep. 48, Box 4, "Pictures for the Work on Pygmy Soles of the Foot".
} 
Abel was not alone: Otto Baader, too, combed through the war prison camps in France in his search for Cro-Magnon types. ${ }^{388}$ Both scientists presented their findings to the Berlin Anthropological Society. ${ }^{389}$ Those involved apparently had no grasp of the fact that such examinations in prison war camps signified a subtle, but nevertheless fundamental boundary crossing - for the first time, scientists of the KWI-A researched on people who were capable of giving consent, but whose possibilities for refusing the examination were at least restricted because they were imprisoned. Even though the examinations as such were harmless, and the probands had to suffer neither pain and fear nor abasement and were not subjected to any health risks, abandoning the principle of informed consent signified a deep rupture.

The war prison camps of the French campaign amounted to a sort of laboratory for race anthropology research. The special conditions of such research resulted in a process of radicalization, which is to be illustrated with a further example: Robert Stigler (1876-1975), ${ }^{390}$ Director of the Institute for the Anatomy and Physiology of Domestic Mammals at the University of Vienna, and his five assistants, performed a series of race anatomy and race physiology tests in a war prison camp near Vienna in July 1940.

In the camp, besides around 15,000 white French, Alsatians, Flemish and Walloons there were also around 2,400 Moroccans, Tunesians and Algerians, 63 Tonkinese, 2 Annamese, 12 Negroes, among them 9 from West Africa, 3 from tropical America, and 16 European Jews, among them several diamond merchants from Antwerp.

As in the examinations by Abel and Baader, here to the question as to the consent of the probands was not posed at all. Even so:

Our examinations met with no resistance at all from the prisoners. The colored were intially very shy, but soon began to trust us and many cheerful scenes ensued. I had the Negroes perform their dances and sing their songs for us. The Moroccans, Tunisians and Algerians were much more negative, the little yellow Tonkinese were the shyest of all $[\ldots] \cdot{ }^{391}$

Recorded in the examinations was the clotting time of the blood, the sinking speed of the blood, the viscosity of the blood, blood pressure, pulse rate, respiration, the upper hearing limit, the threshold of the sense of touch, reaction speed, right-handedness and left-handedness, hair growth on the genitals, and sexual characteristics - the last of these substantiated by numerous photographs. In comparison to the examinations by Abel and Baader, further boundary trangressions can be determined: Not only would the measurements of the naked body and the photographing of the genitals have been perceived by the probands as humiliating and a violation of modesty. In taking blood samples the scientists had gone a step further - this was

\footnotetext{
${ }^{388}$ Baader, Cro-magnide Typen. Baader summoned colonial soldiers from Morocco, Algiers and Tunis. Cf. also Fischer, Tätigkeitsbericht 1942/43, MPG Archive, Dept. I, Rep. 3, No. 20: "Examinations were made of Northern African prisoners (Dr. Baader), a possibility for examining the bones of Guanche limbs as compared to Nordic ones is being worked out in detail."

${ }^{389}$ Fischer, Weißafrika, p. 133.

${ }^{390}$ For a biography: Klee, Personenlexikon, pp. $603 \mathrm{f}$.

${ }^{391}$ Stigler, Untersuchungen, quotes: pp. 26, 27.
} 
a first, albeit minimal, invasive approach. The examinations of the group of researchers around Stigler were thus positioned between those of Abel and Baader and the examinations and experiments of Karl Horneck, which will be depicted at a later juncture.

\subsubsection{Fischer, Verschuer, and the "Final Solution" to the Jewish Question}

Even after the start of World War II, Eugen Fischer and Otmar von Verschuer brought their national and international reputations to bear in order to provide a scientific foundation to legitimate the "total solution to the Jewish question" tackled by the National Socialists, which by late 1941 early 1942 had taken on the character of the "Final Solution" once and for all. For Fischer and Verschuer there could hardly have been a doubt as to what the measures aimed to achieve. They were guests of honor to a working congress at the inauguration of the "Frankfurt Institute for the Investigation of the Jewish Question" (Frankfurter Institut zur Erforschung der Judenfrage) on March 27/28, 1941. The aspired goal of the "total solution" to the "Jewish question," as was bluntly stated here, was the Volkstod ("death of the nation"). The economist Peter-Heinz Seraphim (1902-1979) 392 $^{2}$ pointed out for consideration that the deportation for forced labor in camps in Poland or an overseas colony could also have the consequence of "social pauperization and upheaval," but "by no means the physical self-disintegration of Jewry, for the death of a nation is never a fast death." ${ }^{393}$ The logical conclusion from these comments was, as Benno Müller-Hill emphasizes correctly, that the "physical self-disintegration" would require some assistance. When the deportation of the German Jews began in October 1941, nobody who had participated in the congress in March could have been in doubt as to what was in store for the Jews deported to the East.

This did not prevent Fischer from making an appearance in late 1941/early 1942 as part of a lecture series organized by the German Institute in Paris. In his lecture about "Race and German Legislation," Fischer certified that the "Bolshevist Jews" were of "monstrous mentality" and assigned them to a "different species." Fischer himself emphasized in a report about his trip to Paris that he had found much acknowledgement among the attendant French scientists for his discussion held of the "Negro problem" and the "Jewish problem" in a "very candid, but in purely scientific form" 394 - and this right before the deportation of 165,000 Jews from France was discussed at the Wannsee Conference.

\footnotetext{
${ }^{392}$ For a biography: Klee, Personenlexikon, pp. $579 \mathrm{f}$.

${ }^{393}$ Quoted in Müller-Hill, Tödliche Wissenschaft, p. 48.

${ }^{394}$ Quoted in Weiss, Sword. A German translation of the French text of the lecture is also in Müller-Hill, Tödliche Wissenschaft, p. 49.
} 
As mentioned previously, in 1944 Fischer and the theologian Gerhard Kittel published a book about the "world Jewry of antiquity," essentially a selection compiled by Kittel of ancient sources with a decidedly anti-Semitic perspective. Kittel supplemented the written sources with illustrations of Egyptian mummy tablets, which supposedly constituted further evidence for the worldwide propagation of Jewry. ${ }^{395}$ At Kittel's request, Fischer undertook to determine the "race type" of the persons illustrated. This was not the first time Fischer had done something like this (for instance, he had studied the illustrations on Etruscan tombs and the masks found during excavations in Mycenae), yet in this publication it was practically tangible that Fischer's interpretations of the pictures completely abandoned the basis of precise anthropometry and relied only on intuition - and that his intuition was distorted by anti-Semitism:

Granted, the expert sees for all races, and also for the basic races of the Jews, a number of physiognomic details which we cannot name and fit into the usual model: shape of nose, shape of face, shape of skull, etc. Often a Jew is recognized as a Jew with complete certainty even though he does not have [...] a so-called "Jewish nose." There is something $[\ldots]$ in the Jewish physiognomy that cannot be measured, and can hardly be described in detail such that the reader or listener can visualize it clearly. But no one will doubt that very many Jews can be picked out from groups of non-Jews with complete certainty. [...] It is not permissible to disqualify as unscientific the statement of a general "impression" of "Jewish" in the evaluation of the pictures. ${ }^{396}$

The attempt by Niels C. Lösch to play down Fischer's participation in this antiSemitic pamphlet as an expression of senility ${ }^{397}$ deserves vehement contradiction Fischer, 69 years old at the time, was of remarkably fresh intellect, and his scientific publishing activities extended well into the 1960s. It must also be kept in mind that Fischer's studies on "Jewish physiognomy" were by no means the concern of an individual scholar in retirement, but rather were based on preliminary work performed at the KWI-A at the beginning of World War II.

In late 1939/early 1940 - probably in the first 3 months of 1940 - one assistant and three students made several trips to Łódž ("Litzmannstadt") on Fischer's behalf, ${ }^{398}$ where the group - in a cauldron of executions, pogroms, and synagogue

\footnotetext{
${ }^{395} \mathrm{Cf}$. also Heiber, Walter Frank, p. 463. Upon Fischer's request, Verschuer had copies of the "Jew pictures of Egypt" slides made for the collection of the KWI-A. Cf. Verschuer to Fischer, 31/3/1943, MPG Archive, Dept. III, Rep. 86 A (Münster), No. 9.

${ }^{396}$ Fischer/Kittel, Weltjudentum, p. 113.

${ }^{397}$ Lösch, Rasse, pp. $291 \mathrm{f}$.

${ }^{398}$ The travel costs are accounted for in the cost report for the closing of accounts on March 31, 1940 (for the 1939 fiscal year). The controlling report states: "For a trip undertaken to Lodsch [sic!], now Litzmannstadt, 1853.96 RM were spent. There are discrepancies in the accounting, which could no longer be clarified, as the participants are no longer in the institute's service." On this Telschow commented in the margins: "Seems very expensive to me. Duration how long?" (Bericht über die Prüfung des Rechnungsabschlusses des KWI-A zum 31. März 1940, MPG Archive, Dept. I, Rep. 1 A, Nr. 2409, pp. 74-76, quotes: p. 76). Fischer explained the costs, stating that "all four gentlemen occasionally traveled and worked independently, so that I was not able to give the entire sum of the expenses to the assistant, so that he could pay out the individual amounts, but occasionally had to pay all gentlemen individually. [...] And in so doing the account between their own funds and those of the institute occasionally were somewhat mixed up." Fischer to Generalverwaltung, 11/10/1940,
} 
desecrations, while at the same time ten thousands of Jews were deported from the city and carried off to concentration camps - performed series of anthropological examinations on more than 250 Jews. Among the students were also Harry Suchalla and Christian Schnecke, who were still working as doctoral students of Nachtsheim's at the Institute for Genetic and Breeding Research and were "loaned out" by Fischer, presumably for want of manpower of his own. ${ }^{399}$ This circumstance indicates that the opportunity was favorable and time was pressing. It can be presumed that Herbert Grohmann, a graduate of the first annual SS course at the KWI-A and an assistant to Fischer in the years 1938/39, made the "field research" in Łódž possible, having held the position of senior medical councilor at the newly founded Health Office of "Litzmannstadt" since September 1939.

In a letter of the year 1950 Suchalla willingly provided information about the kind of material collected on these visits and what became of it:

Prof. Dr. Eugen Fischer had authorized me to evaluate the fingerprint and handprint material in 1940 and thus it initially remained in my possession. When I was called up for military service the further analysis remained unfinished and the documents remained in my apartment in Berlin until I found time to hand over the complete materials to the Anthropological Institute in fall 1944. Among the material was a directory of persons with complete data about gender, age, place of birth, descent and social status, ordered sequentially. The material also included the standard anthropometric data recorded in series of anthropological examinations, including index calculations. At the time there was talk of moving the material with the institute archives to somewhere near Neuruppin. ${ }^{400}$

Not only photographs taken by Suchalla and his comrades on their trips to Łódž were included in Fischer's and Kittel's book about "Ancient world Jewry." After the war the fingerprints and handprints from the Łódž ghetto were recovered in Hans Nachtsheim's Institute for Comparative Genetic Biology and Genetic Pathology of the German Research Academy in Dahlem, where they were discovered by Georg Geipel, who, as elaborated elsewhere, had worked at the KWI-A as an expert for dermatoglyphics (and who had introduced Suchalla to the technique of dactyloscopy in 1940). As late as the end of 1950, the publication of this material was discussed in all earnestness in the context of dermatoglyphic race research, but was stopped, presumably upon Fischer's advice. The fingerprints and handprints themselves are untraceable today. However, the anonymized fingerprint formulas of 169 "Litzmannstadt Jews" are included in Geipel's scientific estate. ${ }^{401}$

The incident shows that Fischer was willing to use the "total solution of the Jewish question" at short notice in order to obtain research material, and in return

ibid., pp. 80a-80a v, quote: p. 80a. - The trips must have taken place between September 8, 1939, the day on which Łódž was occupied by the Wehrmacht, and the close of accounts on March 31, 1940. In retrospect, Harry Suchalla dated his stay in Łódž to the year 1940.

${ }^{399}$ The incident shows that a close connection between Fischer and Nachtsheim must have existed before October 1940.

${ }^{400}$ Suchalla to Geipel, 29/12/1950, MPG Archive, Dept. III, Rep. 48, No. 6.

${ }^{401}$ Portfolio "Material Suchalla. Polnische Juden. Fingerleistenmuster, 20/11/50," MPG Archive, Dept. III, Rep. 48, box 3. 
to place the results of his research, as dubious as they might have been, unquestioningly at the service of "Jewish policy." That Fischer regarded his anthropological studies as a contribution to the "total solution of the Jewish question" was demonstrated quite clearly in June 1944, when Alfred Rosenberg (1893-1946), Minister for the Occupied Eastern Territories, invited Fischer to act as one of the presidents of an international "Anti-Jewish Congress" to be convened in Kraków. Fischer accepted the invitation, explaining:

I hold [...] your intention to found a scientific front to defend against the influence of Jewry on European culture and to call together the scientists of all of the nations in conflict with Jewry to be very good and altogether necessary. Yes, it is high time for such an action, for Jewry has been battling us for decades not only politically, but quite certainly in terms of pure intellectural history as well..$^{402}$

The congress never took place. Nevertheless the incident shows how loyally Fischer supported the "Final Solution" even at a point in time when the collapse of the National Socialist state was already clearly imminent. This was also true for his successor, friend and pupil Otmar von Verschuer. In late 1941/early 1942 - the deportation of German Jews had begun a few months previously - he wrote in the Erbarzt:

Never before in history has the political importance of the Jewish question emerged so clearly as today: The whole of Europe in alliance with Japan-led East Asia is battling against the English-American-Russian world power jointly led by Jewry. The nations unified with us recognize more and more that the Jewish question is a question of race, and that they therefore must find a solution like the one we initially introduced for Germany. ${ }^{403}$

This was open approval for the deportation of Jews from the Third Reich, and pled for its expansion to German-dominated Europe. In evaluating this statement it must be kept in mind that the mass murder of mentally ill and mentally disabled people in the gas chambers of the "Aktion T4" in 1940/41 was known to large sectors of the German population, and that information had leaked quickly about the massacres committed by the task groups of the security police and the SD in the occupied territories of Poland and the Soviet Union. When the systematic deportation of German Jews began in October 1941, a significant degree of self-deception was needed to accept the official version of "resettlement" and "work assignment in the East."

As late as 1944 Verschuer, as mentioned above, demanded a "new total solution of the Jewish problem," now that the "historical attempts at solution" - "absorption of the Jews," "seclusion of the Jews through the ghetto" and "the emancipation of Jewry" - had failed. ${ }^{404}$ As to what the "total solution" looked like in the ghettos and extermination camps, there was hardly a scientist in the German Reich who had such profound information as Otmar von Verschuer. Yet, with his research on the development of a serological race test all the way into the final months of the war he made his contribution to this "total solution."

\footnotetext{
${ }^{402}$ Fischer to Rosenberg, 10/6/1944, quoted in Müller-Hill, Tödliche Wissenschaft, p. 80. At Fischer's suggestion Lothar Loeffler also took part in the organization of the congress.

${ }^{403}$ Verschuer, Erbarzt an der Jahreswende, p. 3.

${ }^{404}$ Verschuer, Leitfaden, 2nd edn., pp. 138f., 137.
} 
In addition, under Verschuer's directorship the KWI-A continued, albeit to a diminished degree, to contribute practical legwork on "Jewish policy" in the form of certificates of race and descent. In 1942/43, for instance, Verschuer and his staff members Schade, Grebe, Mengele, Fromme, Baader, and Liebau produced evaluations bringing in a total of 2,340 RM. 405 "As a special war service" the institute also provided "Certificates of Wehrmacht Members (racial descent, marriage permits)." ${ }^{406}$

That Verschuer used his activities as an evaluator to help those suffering racial persecution methodically and systematically, as a war legend claimed, ${ }^{407}$ must be challenged on the basis of today's state of knowledge. It is indisputable that he delivered a judgement advantageous for the individual involved in individual cases. It is also obvious that the test subjects enjoyed his sympathy in these cases. Yet for the assertion that one of his closest friends, the Frankfurt pastor Otto Fricke, made in his denazification testimony of October 1945, that Verschuer had gone "to the limit of scientific credibility [...] in order to prevent people from fall victim to the methods of the National Socialist state," 408 there is no believable source evidence.

Important in this context is a letter by Verschuer to Karl Diehl of February 12, 1942. The subject was the case of the "half-Jewish" physician Werner Wund (1911-1990), to whom approbation was denied in National Socialist Germany and who had found employment in May 1941 as an intern in the remote Eckardtsheim Branch Institute, one of the Von Bodelschwingh Bethel Institutes. His situation had become precarious in September 1941, when the Reich Ministry of the Interior had rescinded the employment permit it had initially granted for Wund. Thereupon Bethel endeavored to procure a certificate of exemption from the Reich Chamber of Physicians. ${ }^{409}$ In this context a file on the "Wund case" must have made its way via the channels of the deaconry to the practicing Catholic Karl Diehl. Diehl had submitted the case to his friend Verschuer, requesting his assistance. However, in a letter of February 12, 1942 Verschuer expressed his regret that he could not undertake anything, "as the question of the racial descent is undisputed." "For such applications a race biology certification plays no role. For it is of no consequence whether or not the individual involved looks Jewish." Verschuer recommended a

\footnotetext{
${ }^{405}$ Lösch, Rasse, p. 407.

${ }^{406}$ Verschuer, Tätigkeitsbericht 1942/43, MPG Archive, Dept. I, Rep. 3, No. 20. The same formulation is included in Verschuer's Tätigkeitsbericht for 1943/44 (MPG Archive, Dept. I, Rep. 3, No. 22), only here he elaborates that this certificate concerned "racial descent, paternity evaluations, marriage permit."

${ }^{407}$ Cf. e.g. Adolf Butenandt/Max Hartmann/Wolfgang Heubner/Boris Rajewski, Denkschrift betr. Herrn Professor Dr. med. Otmar Frhr. v. Verschuer, September 1949, Archives of the University of Frankfurt/Main, Dept. 13, No. 347, pp. 473-485, here: p. 476; Dekan der Medizinischen Fakultät Frankfurt to Hessisches Staatsministerium für Kultus und Unterricht, 9/9/1949, ibid., pp. 414-422, here: p. 418.

${ }^{408}$ Fricke, Kirchliches Urteil über die Persönlichkeit und die wissenschaftliche Arbeit von Herrn Professor Dr. Freiherr v. Verschuer, 26/10/1945, ibid., pp. 427 f., here: p. 428.

${ }^{409}$ On this in detail: Schmuhl, Ärzte in der Anstalt Bethel, pp. 63-66.
} 
"clemency plea to the Reich Chancellory," whereby he was skeptical about the success of such a petition from the outset. Interesting in this context is a passage of his letter in which Verschuer went into his role as an assessor:

Only in those cases in which doubts exist as to the correctness of the blood descent am I consulted as an expert, and in many such cases I have been able to help the people involved decisively. Just recently, for instance, a physician from Stuttgart came to me, whose wife was hitherto supposed to be a full-blooded Jew. From her appearance alone doubts as to this descent were justified. The couple also had four children, who now were supposed to be taken out of school and who would be banned from all higher professions as " 1 st degree mixed-race." In this case I could supply evidence that the woman was not descended from her Jewish father, but had a German physician, since deceased, as her biological father. This just as an example of the cases in which my involvement can be successful. ${ }^{410}$

Here Verschuer was probably alluding to the case of the professor's wife Luise S., in which he had been consulted as an assessor. Verschuer's expert opinion had in fact been successful in declaring Mrs. S., who had been considered a "full Jew" until that time, to be a "half-Jew," by abnegating the biological paternity of her legal father. By no means did this close the case, however, for the husband of Mrs. S. fought for the recognition of his wife as "German-blooded" by questioning the biological maternity of her legal mother as well. The Race Policy Office, to which he addressed his petition, called in the race biologist Wolfgang Lehman from Strasbourg, who, as already mentioned, was a member of the "Dahlem circle." Lehman was to examine photographs to ascertain whether they yielded "indications for a Jewish descent" of Mrs. S. ${ }^{411}$ Since he gathered from the files that Verschuer had already submitted an expert opinion, Lehmann turned to Verschuer first before delivering an opinion himself. The characteristic style of Lehmann's letter to his former colleague makes apparent that he was disposed to agree with the standpoint of Professor S., and that he proceeded from the assumption that Verschuer would agree as well.

The response was different than expected, however. While Verschuer allowed that Mrs. S. belonged to the cases "in which nobody would suspect a Jewish influence. As such one can concede to her husband that she appears to be a 'pure German woman' [...]." But in his expert opinion at the time he had not been able to "lend support for the assumption that she was not the child of her mother. She received notification from the Reich Heritage Office that she was $[\ldots]^{412}$ degree mixed race, and I believe," Verschuer added with slight irritation, "Professor S. ${ }^{413}$ should be content with this." ${ }^{414} \mathrm{He}$ had already delivered a second expert opinion to this end in February 1943. Keep in mind: In June 1943 it would have been easy for Verschuer - based on her external appearance and seconded by a further full

\footnotetext{
${ }^{410}$ Verschuer to Diehl, 12/2/1942, MPG Archive, Dept. III, Rep. 86 A (Münster), No. 7. ${ }^{411}$ Lehmann to Verschuer, 23/6/1943, MPG Archive, Dept. III, Rep. 86 A (Münster), No. 5.

${ }^{412}$ Omission in the original. From a handwritten marginal it can be induced that Verschuer submitted this information later along with a copy of his expert opinion on July 2, 1943. It should read: " 1 st degree mixed race."

${ }^{413}$ Verschuer accidentally used Mrs. S.'s maiden name here.

${ }^{414}$ Verschuer to Lehmann, 26/6/1943, ibid.
} 
professor for race biology and the Race Policy Office of the NSDAP - to relieve Mrs. S. of the stigma of being a "half-Jew," and her children "quarter-Jews" - had he only been willing, despite his scientific conviction, to depart from the result of his first expert opinion in the interest of this human being. This case confirms the judgement Hans-Peter Kröner made about Verschuer as an evaluator on the basis of a case of "race treason" from 1937: ${ }^{415}$ Verschuer was neither one of those scientists who provided incorrect opinions knowingly and deliberately in order to save people, nor one of those who interpreted the race laws extensively to the disadvantage of their subjects. Verschuer was the type of the "correct, law-abiding but merciless evaluators." 416 Of course, Verschuer abetted the emergence of his legend by portraying to his friend Diehl his first expert opinion as emergency assistance for a subject suffering racial persecution, although he did not claim at this juncture to have falsified the findings of the paternity examination. Through this it was possible for the impression to emerge in Verschuer's circle of friends - and also among the affected ${ }^{417}$ - that he used his position as an evaluator to help the persecuted. However, all cases documented by sources prove that Verschuer followed the exact letter of the law and that "scientificity" was the only criterion for his expert opinions.

\subsection{7 “Generalplan Ost” and Wolfgang Abel's Research on Soviet Prisoners of War}

With his appointment to "Reich Commissioner for the Fortification of German Volkstum" Himmler was entrusted with the "ethnic cleansing" of the occupied Eastern territories. Consequently he set a mighty population transfer in motion, whereby the settlement of German nationals in the conquered areas and the deportation of Poles and Jews from these spaces drove each other like cogs in a powerful machine. Yet the forced migration, which was effected starting in winter 1939/40, constituted only a fraction of the planned resettlement program, which was worked out by Himmler's accomplices between 1940 and 1942 and entitled the Generalplan Ost ("General Plan for the East"). ${ }^{418}$

The original Generalplan Ost, which was reworked several times, has not survived. But through two written position papers from the pen of the head of the Race Division in Alfred Rosenberg's Reich Ministry for the Occupied Eastern Territories, Erhard Wetzel (1903-1975), ${ }^{419}$ we know its contents down to the details. Within 20 years at least 10 million Germans were to be resettled in the East. The territories

\footnotetext{
${ }^{415}$ This case was mentioned for the first time by Müller-Hill, Tödliche Wissenschaft, p. 39. A detailed depiction in: Kröner, Von der Rassenhygiene zur Humangenetik, pp. 42-44. Cf. also Meyer, "Jüdische Mischlinge," p. 130.

${ }^{416}$ Kröner, Von der Rassenhygiene zur Humangenetik, p. 42.

${ }^{417} \mathrm{Cf}$. the "Denazification Certificate" printed as a facsimile in Koch, Humangenetik, p. 94.

${ }^{418} \mathrm{Cf}$. in general Heiber, Generalplan Ost; Rössler/Schleiermacher (eds.), Generalplan Ost; Aly/ Heim, Vordenker, pp. 394-440; Madajczyk (ed.), Generalplan Ost.

${ }^{419}$ For a biography: Klee, Personenlexikon, p. 673.
} 
slated for settlement were the occupied areas of Poland, the Baltic countries, Belarus, parts of Russia, Ukraine and Crimea. The population in these areas was estimated at about 45 million, including 5-6 million Jews, whose extermination Wetzel presupposed as a matter of course in his position paper of April 27, 1942. In total, 31 of the 45 million people who lived in the territory destined for German settlement were categorized as "racially undesirable." They were to starve or be expelled to Siberia. According to Generalplan Ost, $80-85 \%$ of the population of Poland, $64 \%$ of the population of western Ukraine and $75 \%$ of the population of Belarus was to disappear. The remainder was to be "Germanized" or to serve the German "master race" as "helot folk." As such, Generalplan Ost was the blueprint of a gigantic program of extermination, expulsion and enslavement. Three scientists from the KWI-A were involved directly or indirectly in elaborating the plan.

Eugen Fischer took part in a meeting in the Ministry of the East protocolled by Wetzel on February 4, 1942 "about the questions of Germanization, especially in the Baltic countries," in which a draft of Generalplan Ost, presumably worked out by Group III B of the RuSHA in late 1941 was discussed - by the way, side by side with his old nemesis Bruno K. Schultz, by now head of the Race Office in the RuSHA. According to the protocol, in this meeting Fischer gave one of the introductory position papers and spoke once during the discussion, when Wetzel asked the group to consider "whether through the industrialization of the Baltic region it might not be possible to scrap the racially undesirable sectors of the population," rather than forcibly deporting them to Siberia. With the formulation "scrapping through industrialization" Wetzel did not mean "extermination through labor." By way of explanation he added, namely: "If they [the 'racially undesirable' sectors of the population] were given suitable pay, in particular, if their cultural condition were to be raised, a drop in the birthrate would be expected." Wetzel thus set his hopes in the regularly observed drop in birthrates in the industrialized states as a means of making the sectors of the Baltic population that were not to be "Germanized" vanish in subsequent generations. In opposition Fischer expressed misgivings: The "better standard of living" could, contrary to Wetzel's expectation, "easily lead to a rise in birth rates." Wetzel admitted that Fischer's view was "correct to the extent that $[. .$.$] those concerned are unmistak-$ ably anti-social." ${ }^{\prime 20}$ In short the brief exchange between Fischer and Wetzel amounted to the scholar coming out against the representatives of the Ministry of the East and with the representatives of the SS for large-scale deportations from the Baltics to Siberia, and thus giving preference to a more radical variant of "ethnic cleansing." In spite of this, Fischer's consulting activity continued to enjoy high estimation in the Ministry for the East. He played a key role in Rosenberg's plans for the founding of a "Reich Headquarters for Research on the East." In a file note for Hitler of March 23, Rosenberg informed the Führer that he had "thought of" Fischer to fill the position at the Reich Headquarters, "as a representative personality for biological research and a leading member of the Kaiser Wilhelm Society."

\footnotetext{
${ }^{420}$ Quoted in Heiber, Generalplan Ost, p. 295.

${ }^{421}$ Quoted in Müller-Hill, Tödliche Wissenschaft, p. 52.
} 
In a detailed position paper on Generalplan Ost of April 27, 1942, Wetzel took reference to Fritz Lenz and Eugen Fischer in the section about "German Settlement Issues." This section concerned the question as to whether southern Ukraine and Crimea would come into question for German settlement because of the climate there. Lenz, as Wetzel reported, had "taken the standpoint that the climatic conditions in these regions were detrimental for the settlement of the Nordic-Phalian appointed race." In this Wetzel must have referred to Lenz's exposé submitted to the RuSHA in January 1940, Bemerkungen zur Umsiedlung unter dem Gesichtspunkt der Rassenpflege ("Remarks on Resettlement under the Aspect of the Care for the Race"). Lenz continued to concern himself intensively with the issues involved in "East settlement," and advised the SS physician Hellmuth Thieme ("1917), who had been involved with the processing of marriage applications at the RuSHA since 1942, on his dissertation on the topic of "The Selection of New Peasants and Their Importance for a Race Hygenic Population Policy." ${ }^{422}$ In December 1941, Eugen Fischer, too, expressed his opinion on the question of German settlements in southern Ukraine and on the Crimean peninsula. Wetzel cited him with the words "that a settlement of German people in these regions could only be considered if there was a conscious effort to create rich wooded regions all over and thus bring about a change in climate." 423

In his exposé of April 27, 1942 Wetzel finally cited a third scholar from the institute in Dahlem: Wolfgang Abel. After being called up for military service, Abel had first seen action in the Luftwaffe, but after he was wounded he was transferred to the Department for Army Personnel Controlling as a consulting anthropologist. As mentioned above, in this capacity he had examined colonial soldiers held in war prison camps in occupied France in 1940. In winter 1941/42, accompanied by two army psychologists, he then visited various war prison camps in which soldiers of the Red Army were crowded together in close quarters. ${ }^{424}$ On behalf of the Superior Command of the Wehrmacht, he subjected the Russian prisoners of war to crude anthropological evaluation. His findings, which he presented to a larger public in a lecture at the "East Conference of German Science" (Osttagung

\footnotetext{
${ }^{422}$ Thieme, Neubauernauslese. For a biography: Lösch, Rasse, p. 575. However, Lenz was disappointed with his dissertation, completed in 1943. Cf. ibid., pp. $378 \mathrm{f}$.

${ }^{423}$ Quoted in Heiber, Generalplan Ost, p. 322. Wetzel's comments on the "streaming in of alien, non-European blood into our Volkskörper (national body)" could also be traced back to research performed at the KWI-A: "The investigations performed by the Race Policy Office of the NSDAP have yielded the fact that interbreeding with Germans takes place continuously as a consequence of the foreigners residing in the territory of the German Reich. The German woman plays a role in this that is anything but honorable. At issue here are Chinese, Near Easterners, Indians and other kinds of foreigners, who engage themselves with German women today in a manner that has provoked great strife in the Volk. Hundreds of births of half-breed children have already been registered. Very numerous are the half-breed children of Chinese and Near Easterners. Here one can almost establish the rule of thumb that every foreigner leaves at least one illegitimate child here "(quoted in ibid., p. 323). This passage apparently incorporates the findings of the dissertation by Yun-kuei Tao about "Bastards of Chinese Men and European Women."

${ }^{424}$ Müller-Hill, Tödliche Wissenschaft, p. 141.
} 
der deutschen Wissenschaft) flowed directly into Wetzel's exposé. According to Wetzel, Abel had reached the conclusion:

[T]hat in the Russians much stronger Nordic race elements are present than had been presumed up to this time. In addition to these truly Nordic race elements, the great mass of which probably have been located in this region for some time now, especially in the northwestern areas of Russia, and which cannot be traced back solely to Germanic, especially Varangian immigrants, there are a predominant number of light-skinned, primitive Caucasian, more or less long-headed race types, who by no means fall under the 6 races of Günther's system, ${ }^{425}$ and cannot be explained as Caucasian-Mongoloid hybrid forms either, but rather constitute the undoubtedly ancient Caucasian race forms that have yet to be described in detail. Also present among the Russians, primarily in the western regions, are eastern Baltic influences. However, these eastern Baltic race characteristics are by no means as strong as was previously presumed.

At the congress, Wetzel continued to relate, Abel had proposed two different "solutions" to this delicate race question, which showed how Abel's advantageous judgement about the racial composition of the Russian nation ultimately cut both ways:

Either the eradication of the Russian nation, or alternatively, the Germanization of the portion of the Russian nation with Nordic characteristics. [...] This concerns not only the annihilation of the culture of the Muscovites [...]. Rather, it concerns the annihilation of Russian Volkstum itself, splitting it up. Only if the problems here are viewed consistently from the biological, especially race biological standpoint, and if, accordingly, German policy is established in the East, will we have the possibility of meeting the danger threatening us from the Russian Volk.

The "very serious comments by Abel," according to Wetzel, deserve "the very greatest attention." The "path of liquidating Russian Volkstum" suggested by Abel, however, aside from the fact that its "execution [was] hardly possible," was "out of the question for political and economic reasons." ${ }^{26}$ However, the strategy that Wetzel himself developed in the following - fragmentation of the Russian population, "racial lixiviation of Russian Volkstum," the "singling out the Nordic clans present in the Russian nation and gradual Germanization," 427 sinking of the Russian birthrates - was largely oriented to Abel's biologistic perspective. What is more: Because Abel in all seriousness posited the idea of physically exterminating many millions of people, he set a negative precedent against which all other proposed solutions, no matter how radical they were, seemed moderate.

Abel continued his anthropological examinations of Russian prisoners of war, intensifying his connection to the SS Ahnenerbe ("Ancestral Heritage Society") at the beginning of 1943 - presumably not least with a view to his own uncertain future prospects, as the call to Fischer's vacated professorial chair met with

\footnotetext{
${ }^{425}$ Hans F. K. Günther differentiated between the Nordic, Phalian, Mediterranean, Dinaric, Alpine and eastern Baltic races.

${ }^{426}$ Wetzel, Stellungnahme und Gedanken zum Generalplan Ost des Reichsführers SS, 27/4/1942, reprinted in: Heiber, Generalplan Ost, pp. 297-324, quotes: p. 313.

${ }^{427}$ Ibid., p. 315.
} 
unexpected resistance. ${ }^{428}$ Abel sought cover with the ornithologist and SS Sturmbahnführer (Major) Ernst Schäfer (1910-1992). ${ }^{429}$ After three expeditions to Tibet - he had just returned from the last in August 1939, Schäfer had taken over the "Department for the Central Asian Research and Expeditions" of the Ahnenerbe society in 1940, which developed to become a "Reich Institute" of its own under his direction. The "Sven Hedin Institute for Central Asia and Expeditions," soon the largest department of the Ahnenerbe, with its own domicile in the medieval castle of Mittersill in Pinzgau, had been opened on January 16, 1943 on the occasion of the 470th anniversary of the University of Munich and the awarding of the honorary doctorate to Sven Hedin (1865-1952). One week later, on February 23, 1943, Abel, who had performed anthropological examinations of around 7,000 Soviet prisoners of war by this time, turned to Schäfer with a request for support - a clever move, as Schäfer had since encroached on the entire area of the natural sciences within the Ahnenerbe organization. Abel's concrete request was that the anthropologist and SS Hauptsturmführer (Captain) Bruno Beger (* 1911) ( $^{430}$ be assigned to him. ${ }^{431}$ Beger had originally belonged to the RuSHA, then was transferred to Himmler's personal staff, took part in Schäfer's expedition to Tibet in $1938 / 39$ as an anthropology student, entered Schäfer's Department for Central Asian Research and Expeditions in the Ahnenerbe in 1940, and took his doctorate in anthropology with Ludwig Ferdinand Clauss.

On March 8, 1943 Schäfer forwarded Abel's remarks to Himmler's personal assistant Rudolf Brandt (1909-1948), ${ }^{432}$ with the request that he report them to the Reichsführer SS. ${ }^{43}$ After intial skepticism, Himmler's staff received Abel's research plans quite positively. Not wanting to make a decision without consulting the directors of Ahnenerbe, however, the managing director of this organization, Wolfram Sievers (1905-1948) was called in. ${ }^{434}$ Sievers first consulted with a number of staff members at the "Institute for Military Science Application Research" (Institut für wehrwissenschaftliche Zweckforschung) under his direction, which, founded in 1942, functioned like a "state within the state of the 'Ahnenerbe'," 435 which also approved Abel's research plans. On May 3, 1943 he wrote to Brandt that he held

\footnotetext{
${ }^{428}$ Lösch, Rasse, pp. 401 f. Even though Abel had been drafted into military service, he was still a departmental director at the KWI-A and maintained constant contact with the institute. As such, his examinations of Soviet prisoners of war and the demands and recommendations derived from these studies cannot be factored out of the KWI-A's responsibility, especially since Abel's anthropological studies in war prison camps were a direct continuation of his prewar work in the context of the institute.

${ }^{429}$ For a biography: Kater, “Ahnenerbe,” pp. 79f., 211-218; Klee, Personenlexikon, p. 523.

${ }^{430}$ For a biography: Kater, “Ahnenerbe," pp. 208-211; Klee, Personenlexikon, p. 36.

${ }^{431}$ Kater, “Ahnenerbe," p. 208.

${ }^{432}$ For a biography: Ebbinghaus/Dörner (eds.), Vernichten, p. 626; Klee, Personenlexikon, p. 71.

${ }^{433}$ Schäfer to Brandt, 8/3/1943, Cf. Lösch, Rasse, p. 402.

${ }^{434}$ For a biography: Ebbinghaus/Dörner (eds.), Vernichten, pp. 643f.; Klee, Personenlexikon, p. 583.

${ }^{435}$ Kater, “Ahnenerbe," pp. 255-257, quote: p. 257.
} 
[T] he evaluation of the examination material to be very imporant in order to obtain reliable documents and then affect the execution of the measures. Therefore we should make the anthropologists slated for the Caucasus project, Dr. [Heinrich] Rübel, Dr. [Hans] Endres ${ }^{436}$ and Dr. [Hans] Fleischhacker, ${ }^{437}$ available until the analysis has been completed. If the Reichsführer-SS approves the application, however, then we must come to a precise agreement with Prof. Abel as to how long the designated anthropologists will have to be available for the evaluation. ${ }^{438}$

What was the "Caucaus project" mentioned here? On August 10, 1942, 2 days after the Wehrmacht had captured the oil fields of the Caucasus, Heinrich Himmler ordered the "Ahnenerbe" to prepare a scientific expedition led by Schäfer in order to explore the Caucasus under the aspects of botany, zoology, entomology, geophysics, and also anthropology. The planning for this Unternehmen $K$ as Michael H. Kater establishes, "exceeded in scale everything that came before it." ${ }^{439}$ With the defeat of Stalingrad the plan for an SS expedition to the Caucasus may have lost any basis in reality, but Unternehmen $\mathrm{K}$ was not abandoned for good until January 1944. Thus it was from the pool of scientists involved in this planned Caucasus expedition that three anthropologists were detached temporarily for Abel's project of an anthropological study of Russian prisoners of war.

In a further letter to Brandt of May 22, 1943 Sievers stated more precisely that the evaluation of the material from the study was "extraordinarily important, because labor is to be assigned, and also for demographic, economic and cultural reasons. [...] However, Prof. Dr. Abel should be disposed to concentrate his work above all on the question of the individual groups' treatment and utilizability for labor in the war and to orient his work toward the solution of these questions." 440 As such, Abel's examinations were embedded in a new context. After the defeat at Stalingrad, the labor administration under the direction of the "General Deputy for the Employment of Labor," Fritz Sauckel (1894-1946), made every effort to effect the deployment of foreign forced laborers under the banner of "European Workers against Bolshevism." ${ }^{441}$ Anthropological expertise was welcome in the attempt to

\footnotetext{
${ }^{436}$ The psychologist Hans Endres (* 1911) was employed by the RuSHA in 1942. Cf. Klee, Personenlexikon, p. 135.

${ }^{437}$ Hans Fleischhacker (* 1912) worked at the RuSHA in 1941 and served as an aptitude tester for the Germanization of Poles, especially in Łódž. Cf. Klee, Personenlexikon, p. 155.

${ }^{438}$ Sievers to Brandt, 3/5/1943, quoted in Lösch, Rasse, pp. $402 \mathrm{f}$.

${ }^{439}$ Kater, "Ahnenerbe," p. 214. - Independent of this large-scale project, the Institute for Political Geography of the NS Ordensburg (official SS training center) "Falkenburg am Krössinsee" addressed the KWI-A in June 1942, requesting that it make available "for preparatory works for deployment in the future Reich Commissariat in the Caucausus [...] data and material about population density, races, nations and religions in the Caucasian and central Russian areas, respectively." Institut für politische Erdkunde to KWI-A, 9/6/1942, MPG Archive, Dept. I, Rep. 1 A, No. 2400, p. 230.

${ }^{440}$ Sievers to Brandt, 22/5/1943, quoted in Lösch, Rasse, p. 403. Sievers had expressed himself quite similarly in a letter to Richard Korherr (*1903), the Inspector for Statistics at the Reichsführer-SS Office, on 29/4/1943. Cf. Kater, “Ahnenerbe,” p. 209.

${ }^{441}$ For background: Schmuhl, Arbeitsmarktpolitik, pp. 307-317.
} 
differentiate from the giant army of "Eastern workers" individual "racially more valuable" groups, who were supposed to be spurred on to higher performance by offering them better living and working conditions, or so the apparent calculation of the Ahnenerbe. By way of precaution, Sievers had Rübel, Endres, and Fleischhacker exempted from the staff of Unternehmen K on the very same day.

Sievers further proposed in his letter to Brandt of May 22, 1943 that the three anthropologists to be detached to Abel could take care of an additional mission on this opportunity:

Once access to the Auschwitz camp is possible again, these anthropologists could also perform the examination there for that collection of 150 persons of which you are familiar. Since at this time, as SS Obersturmbannführer ( $1^{\text {st }}$ Lieutenant) [Adolf] Eichmann informed me, there is especially suitable material available, the time would be particularly opportune for this examination. ${ }^{442}$

In this Abel's project was linked with another one that had been pursued for quite some time by the Ahnenerbe: the erection of a "Jewish skeleton collection." ${ }^{43}$ The first impetus for this project proceeded from Bruno Beger in December 1941. On the search for a scientist who was to take control over the setting up of the collection, the organization quickly hit on August Hirt (1898-1945), ${ }^{444}$ who held the chair for anatomy at the newly founded "Reich University" in Strasbourg. From late 1941/early 1942 he was courted by Sievers, Brandt, and Himmler, so that he took over a primary role in the framework of the natural science research empire that was to emerge under the protectorate of the SS. On December 29, 1941 Brandt passed on to Sievers a generally formulated directive of Himmler's that Hirt should be "given the possibility to engage in experiments of every kind that could support his research work, using prisoners, professional criminals who will never be released anyway, and persons awaiting execution." 445 Initially the Jewish skeleton collection was an issue. Rather, the hope was to win over Hirt for the directorship of a planned Institute for Entomology. The anatomist had made a name for himself with his work in the fields of the sympathetic nervous system and intravital microscopy, and especially this latter area was to be used in the research of new possibilities for pest control. In the end, Hirt's criminal experiments with poison gas (mustard gas) on prisoners at the Natzweiler concentration camp emerged from these plans. ${ }^{446}$ Yet back in January 1942 there was also talk of "anthropological studies" 447 Hirt was supposed to perform. Probably the Jewish skull collection was meant with this. In any case, a report by Hirt about his research fields, which

\footnotetext{
${ }^{442}$ Sievers to Brandt, 22/5/1943, quoted in Lösch, Rasse, p. 403.

${ }^{443}$ On the following: Mitscherlich/Mielke (eds.), Medizin, pp. 174-182; Kater, "Ahnenerbe," pp. 245-255; Klee, Auschwitz, pp. 356-391; Wojak, Das "irrende Gewissen”; Lang, Grab.

${ }^{444}$ For a biography also: Klee, Personenlexikon, p. 259.

${ }^{445}$ Brandt to Sievers, 29/12/1941, BArch. Berlin, BDC, Wi A-0494. Cf. Sievers to Hirt, 3/1/1942, BArch. Berlin, BDC, B-254.

${ }^{446}$ Cf. on this: Klee, Auschwitz, pp. 361-366; Schmaltz, Kampfstoff-Forschung, pp. 349-584.

${ }^{447}$ Quoted in Kater, “Ahnenerbe,” p. 247.
} 
Sievers forwarded to the Reichsführer SS on February 9, 1942, was appended by an exposé in which the plan for establishing the Jewish skull collection was explained in greater detail:

Comprehensive skull collections exist for nearly all races and nations. Only of the Jews are there so few skulls available to science that their processing does not permit any certain results. The war in the East now offers us the opportunity to remedy this lack. In the JewishBolshevist commissars, who embody a disgusting, but characteristic class of sub-humans, we have the possibility to acquire a concrete scientific document by securing their skulls. ${ }^{448}$

The plan was frustrated by the reality of the war. Hirt, Sievers, and Beger thus agreed to procure the material not from the front, but from a concentration camp and then not just skulls, but entire skeletons. On November 2, 1942, in a secret letter to Brandt, Sievers wrote, "for certain anthropological examinations [...] 150 skeletons of prisoners (Jews) [were] required, which are supposed to be provided from the Auschwitz concentration camp." ${ }^{49}$ The Head Office for Reich Security was instructed to issue a corresponding directive. Brandt forwarded this request to the SS Obersturmbannführer Adolf Eichmann (1906-1962), head of the Department for Jews (Judenreferat) IV B 4 in the Head Office for Reich Security.

As the letter from Sievers to Brandt of May 22, 1943 indicates, Eichmann had just sent word that "at present especially suitable material" was available in Auschwitz for the Jewish skeleton collection. On June 6, 1943 Bruno Beger arrived in Auschwitz, surveying technician Willi Gabel having been sent ahead. On June 10 Fleischhacker followed, temporarily detached from the RuSHA to the Ahnenerbe. By June 15 Beger had selected and, assisted by Fleischhacker, Gabel, and several prisoners, measured the victims. In total Beger had selected, as Sievers wrote Eichmann on June 21, " 115 persons, of which 79 were Jewish men, 2 Polish men, 4 central Asian men, and 30 Jewish women." 450 The unfortunate were deported to the Natzweiler concentration camp in August 1943 and murdered there in a specially furnished gas chamber under Hirt's direction, and some parts of their bodies conserved, others preserved.

So how was Abel's project of anthropological examinations of Soviet prisoners interlocked with this complex of crimes? And how did it continue? At present these questions can be answered only in part due to the fragmentary sources available. What is clear is that Abel, armed with a research contract from the Reich Research Council, ${ }^{451}$ continued working on his "race biological studies of Eastern nations." In September 1943, with Sievers' help, he managed to extend his "indispensable"

\footnotetext{
${ }^{448}$ Quoted in Mitscherlich/Mielke (eds.), Medizin, p. 174.

${ }^{449}$ Quoted in Kater, “Ahnenerbe,” p. 249.

${ }^{450}$ Quoted in Mitscherlich/Mielke (eds.), Medizin, p. 175. Beger's own interest focused on the four "central Asian" prisoners. "Two Usbeks, 1 Usbekian-Tadjik mixed-race and 1 Chuvash from the Kasan region [were] measured and cast," Beger reported to his superior Schäfer on June 24, 1943. "In addition, just for our institute" (quoted in Kater, "Ahnenerbe," p. 251).

${ }^{451}$ Abel to Breuer, 13/12/1944, BArch. Koblenz, R 73/10.005. Cf. Müller-Hill, Tödliche Wissenschaft, p. 109 (note 74).
} 
status. This was justified with the fact that it was absolutely necessary that the examinations of war prisoners be concluded, "since it is imperative that the racebiological selection and evaluation of the Great Russians be clarified for later deployment, for up to this point we knew almost nothing about them and were misguided by incorrect conceptions." ${ }^{452}$ Sievers' intercession can be interpreted as an indication that Abel's research on Russian prisoners of war continued to be performed in cooperation with the Ahnenerbe. This fits in with the fact that in October 1943, Beger suggested continuing the anthropological studies begun in Auschwitz on the "Mongoloid" types among the Soviet prisoners of war "by taking advantage of the material handed to us by this war in the form of prisoners." 453 With the help of Schäfer and Sievers, in spring 1944 Beger succeeded in deploying the wounded anthropologist Rudolf Trojan $\left({ }^{*} 1917\right)^{454}$ to various camps in order to measure "central Asian" prisoners of war.

Another question is whether and to what extent the SS was involved directly in Abel's anthropological examinations. In response to his letter of May 3, 1943, in which he suggested providing Abel with three assistants, the anthropologists Rübel, Endres, and Fleischhacker, Sievers received an answer on June 23, 1943. Brandt had presented the plan to Himmler and now imparted the decision of the Reichführer SS:

One of the 3 anthropologists can be detached for the short term, for 3, 4 or 5 weeks, while instead of the other two suitable inmates of the Sachsenhausen concentration camp should assist. For this it would be necessary that Prof. Dr. Abel and one of the three SS Führer move out to Sachsenhausen for this period to take care of their work there [....$^{455}$

Whether Fleischhacker - for only he came in question under the circumstances, as Endres and Rübel were no longer available ${ }^{456}$ - was actually dispatched to Abel's project after his assignment in Auschwitz, and whether Abel actually set up a base in the Sachsenhausen concentration camp, must remain an open question at the current state of knowledge. The assumption that Abel's examinations of Soviet prisoners of war took place in the Sachsenhausen camp is highly plausible. For one, Sachsenhausen was very conveniently located, not only near Berlin, but more importantly, not far from the KWI-A's External Department for Tuberculosis Research in Sommerfeld/Beetz. Secondly, a large number of Soviet prisoners of

\footnotetext{
${ }^{452}$ File note by Sievers about a meeting with Abel on 18/9/1943, 30/9/1943, BArch. Berlin, R 26 III/122. I thank Helmut Maier for the reference to this document. - In a letter of June 23, 1943 Sievers mentioned that Abel "occasionally is mobilized for collaboration by the "Ahnenerbe" (Sievers to Persönlicher Stab des Reichsführers-SS, 23/6/1943, IfZ, MA 287, p. 9443). Sievers was referring to a devastating expert opinion by Abel about abstruse proposals by the selfproclaimed breeding researcher Kurt F. König of the "Internal Office for Speciation Research" (Eigenstelle für Artungsforschung) (cf. ibid., pp. 9444-9448).

${ }^{453}$ Beger to Sievers, 25/10/1943, quoted in Kater, "Ahnenerbe," p. 211.

${ }^{454}$ For a biography: Klee, Personenlexikon, pp. $630 \mathrm{f}$.

${ }^{455}$ Quoted in Lösch, Rasse, p. 403.

${ }^{456}$ Cf. ibid., p. 404.
} 
war were held in Sachsenhausen, such that this would open up a further field of activity for Abel's ambitions. Since 1942 Abel had pursued the idea "of an instructive collection for the race history of Europe and the world, the development of race, population movements domestic and international, etc." ${ }^{57}$ Should this idea have taken on shape over the course of the war, a portion of the material could have come from Sachsenhausen. From the testimony of witnesses we know that skulls, skeletons, and other body parts were sent from the Sachsenhausen concentration camp to universities and other anatomical institutes. ${ }^{458}$ But specimens could also have come from Auschwitz - at least the former prison physician Miklos Nyiszli (1901-1956) mentions in his memoirs that Jewish skeletons were sent from Auschwitz to Berlin for a "race exhibition." 459

\subsubsection{The Kaiser Wilhelm Institute for Anthropology, Human Heredity and Eugenics and the Research Accompanying the Genocide of the Roma and Sinti}

In the first years of the Third Reich, "Gypsy policy" for the most part remained in the trails blazed for it in the Weimar Republic. ${ }^{460}$ The outlines of a new "Gypsy policy" began to emerge as individual Sinti and Roma were subjected to compulsory sterilization in accordance with the GzVeN. From fall 1935 on they also fell under the "blood protection" law, which enacted bans on marriage between "Germans" and "members of alien races" - besides Jews, as the commentators of the Nuremberg Race Laws emphasized expressly, this meant above all the Sinti and Roma - and also under the "marriage health law," which prohibited marriage for the "inferior," regardless of their ethnic heritage. This complex of laws signaled a shift in "Gypsy policy." Had the "Gypsy question" been conceived as a problem of regulatory policy up to that time, now it was reinterpreted, like the "Jewish question," as a "race problem." As such the Sinti and Roma found themselves doubly suppressed: Like the Jews they were stigmatized as an "alien race" in terms of race anthropology; as mentally ill and mentally disabled they were also considered to be "genetically inferior aliens to the community" in terms of race hygiene. The supposed

\footnotetext{
${ }^{457}$ Abel to Sievers, 6/6/1942, BArch. Berlin, BDC, Research Wolfgang Abel.

${ }^{458}$ Hrdlicka, Alltag, p. 107. - Prisoners with unusual physical attributes like bone deformations or abnormalities of the limbs were also murdered in Sachsenhausen in order to make their corpses available to science. Cf. e.g. Naujoks, Leben, p. 81. In these cases the KWI-A was one of the potential recipients. In this the specialist was Hans Grebe, who worked at the reception center of the KWI-A in the "Haus am See" in Beetz starting in September 1943, in the direct vicinity of the External Department for Tuberculosis Research and not far from the Sachsenhausen camp. Cf. Verschuer to Fischer, 20/9/1943, MPG Archive, Dept. III, Rep. 86 A (Münster), No. 9.

${ }^{459}$ Nyiszli, Jenseits, pp. 125-128. Cf. also Sachse/Massin, Forschung, pp. $27 \mathrm{f}$.

${ }^{460}$ On the preliminary history: Hehemann, "Bekämpfung des Zigeunerunwesens." For the basics of the following: Zimmermann, Rassenutopie, esp. pp. 125-152.
} 
"anti-sociality" of the Sinti and Roma was interpreted to be the consequence of a genetic defect, which, in term, was traced back to the interbreeding of the "genuine Gypsy lineage" with the "German-blooded" lower classes.

The racist conception of National Socialist "Gypsy policy" necessitated the collaboration of scientific functionary elites. The scientific center to "combat the Gypsy nuisance" was the "Race Hygiene and Population Biology Research Office," which was founded in spring 1936 at the Reich Health Office in Berlin-Dahlem. It was headed by Robert Ritter (1901-1951), ${ }^{461}$ who was chief physician in the Youth Department of the Tübingen University Psychiatric Clinic before turning to the research of "vagabond stock" and "Gypsy half-breeds" full time in 1934/35. From spring 1937 on, the research office dispatched "mobile working groups," which sought out Sinti and Roma at gathering places, in camps, prisons, and institutions, subjected them to anthropometric examination and interrogated them - even under the application of threats and violence - to ascertain their family backgrounds. This information was supplemented by genealogical material from church and civic registries, private and state archives, as well as communications from the police, the courts, community authorities, welfare institutions, prisons, and penitentiaries. The information was compiled into family tables at the "Gypsy Clan Archive" of the Research Office, which, in turn, served as the data source for the expert opinions produced by the Research Office. By March 1944 the Research Office produced almost 24,000 such expert opinions, in which the subjects were classified according to a sophisticated system as "Gypsies" or "Gypsy half-breeds" of various degrees. The staff of the Research Office was aware of the deportation of the German Sinti and Roma to the Auschwitz concentration and extermination camp in March 1943. In spite of this they continued to write their certified expert opinions, which constituted a decisive foundation for internment in Auschwitz.

The Research Office also took on consulting duties. It advised the offices of the criminal police on the application of the "Gypsy legislation," the Wehrmacht and the Reich Labor Service on physical inspections, the groupings of the NSDAP on the admission and expulsion of members, the school boards on school admissions, factory managers on hiring and labor offices on the provision of labor, rural authorities on the issuing of peddling licenses, mayors, National Socialist Welfare Offices in welfare questions, and tax offices regarding the granting of child subsidies. Above all, however, Ritter and his staff instructed medical officers and registry officials about how to behave when Sinti and Roma applied for banns and marriage loans. By the second half of the war, the Research Office also delivered recommendations for sterilizations and abortions among Sinti and Roma. Finally, by 1938 at the latest, Ritter intervened in the discussion about a "Reich Gypsy Law," but this legislation was never introduced.

Shortly after the founding of the Race Hygiene and Population Biology Research Office, close connections developed with the nearby KWI-A. Wolfgang Abel, who, as mentioned above, had undertaken a "study trip" to Romania in 1935/36 in order

\footnotetext{
${ }^{461}$ For a biography: Hohmann, Robert Ritter, esp. pp. 133-184; Zimmermann, Rassenutopie, pp. 127-130; Klee, Personenlexikon, pp. 499 f.
} 
to examine the Roma living there with regard to "the question crossbreeding," established contact with Ritter in March 1937 in order to draw his attention to the supposed importance of fingerprints in differentiating between "purebred Gypsies" and "Gypsy mixed-breeds". At Abel's instigation, from this time forth the anthropological files of the Sinti and Roma collected by the "mobile working groups" of the Research Office also included fingerprints, which were registered by the police as a matter of routine. ${ }^{462}$ At the beginning of World War II, two doctoral students and scientific staff members of the KWI-A moved to Ritter's Research Office: Adolf Würth, ${ }^{463}$ as mentioned above, had earned his doctorate under Eugen Fischer in 1937 with a dissertation on the emergence of flexion creases on the human palm. Immediately thereafter, Würth, who had also been interested in the "Gypsy question" since 1931/32, started at Ritter's Research Office. Working independently on Ritter's behalf from the Criminal Police Office in Karlsruhe, in 1937/38 he examined of the Sinti and Roma in southern Germany. On September 17/18, 1937 he represented his boss at the annual conference of the German Society for Race Research in Tübingen. At the conclusion of his lecture, Würth expressed his conviction that the National Socialist state, just as it had "solved the Jewish question," would "also settle the Gypsy question in principle." 464 In 1939 Ritter's group of scientists was joined by Brigitte Richter (married: Hercher), who, as also mentioned above, had earned her Ph.D. in 1936 in the context of the the large-scale "German Race Science" project with a dissertation about the Upper Hessian villages of Burkhard and Kaulstoß. Until her departure in 1943 she was responsible for registering the descent of Sinti and Roma. ${ }^{465}$ Gerhart Stein (1910-1971) also had connections to Ritter. ${ }^{466}$ In 1936 he had approached Verschuer with the request that he serve as advisor for a dissertation on the "Gypsy question." In summer 1936 Stein performed the first anthropological examinations for his dissertation in Berlin, where around 600 Sinti and Roma had been arrested and sent to the newly established internment camp in Marzahn in preparation for the Olympic Games. ${ }^{467}$ In late 1938 Stein submitted his dissertation, which was based on the anthropometric measurement of 247 Sinti and Roma that he had performed in summer 1937, predominantly in Berlin, ${ }^{468}$ but in part in Frankfurt. Stein determined the blood groups of samples from 244 Sinti and Roma in the second half of 1937 in the laboratory of the Institute for Genetic Biology and Race Hygiene. In 1939, even before the dissertation was printed in 1941, Verschuer used Stein's study to extol the pioneering

\footnotetext{
${ }^{462}$ Hohmann, Robert Ritter, p. 221.

${ }^{463}$ On the following: ibid., pp. 275-280.

${ }^{464}$ Würth, Bemerkungen, p. 98.

${ }^{465}$ Lösch, Rasse, p. 572; Hohmann, Robert Ritter, p. 314.

${ }^{466}$ On the following, ibid., pp. 291-296; Sandner, Frankfurt. Auschwitz, pp. 184-196.

${ }^{467}$ Cf. Milton, Vorstufe; Brucker-Boroujerdi/Wippermann, “Zigeunerlager” Berlin-Marzahn.

${ }^{468}$ There is no concrete evidence that Stein was in contact with the KWI-A while performing research in Berlin in 1936/37, yet in view of the close collaboration between Fischer and Verschuer this may be presumed.
} 
role of his own institute as opposed to Ritter's Research Office. ${ }^{469}$ What Verschuer neglected to mention at this juncture: After he left the institute in Frankfurt, Stein had participated in one of Ritter's "mobile working groups" from January to April 1938. The entanglements of the various personnel show that there were close contacts between the KWI-A and the Reich Health Office's Research Office, even though Fischer and Verschuer had strong reservations about Ritter.

Under shady circumstances, Eugen Fischer helped Eva Justin (1909-1966), ${ }^{470}$ Ritter's "right hand," obtain her Ph.D. in 1943. After training as a nurse, Justin had begun work as an intern in Ritter's Genetic Biology Laboratory at the University of Tübingen Clinic in 1934. In the Race Hygiene and Population Biology Research Office she effectively acted as Ritter's deputy. In 1937 she registered as a student at the University of Berlin, where she supposedly studied anthropology, genetic psychology, race hygiene, criminal biology, and ethnology - although she could not provide evidence of a methodical program of study when she registered for her doctorate in 1943. She had accepted a dissertation topic proposed by Kurt Gottschaldt, but then changed it without consulting Gottschaldt, and then on her own, so to speak, written her dissertation about "The Fates of Gypsy Children Raised as Aliens and their Progeny." Upon Fischer's recommendation, on the basis of this dissertation she was permitted to register for the doctorate with a major in anthropology and minors in ethnology and criminal biology. Fischer, Ritter, and the ethnologist Richard Thurnwald (1869-1954) passed the dissertation, which quite obviously did not meet basic scientific standards. The oral examination by Fischer, Abel, Thurnwald and Ritter took place on March 24, 1943 in Ritter's private residence. Why Fischer, Abel, and Thurnwald were willing to issue positive evaluations as an obvious favor to Ritter becomes clearer upon perusal of Justin's references: The documents include letters of recommendation from Hans Reiter, President of the Reich Health Office; Herbert Linden, Hitler's Reich Deputy for Sanatoriums and Hospitals, one of the key figures in the NS "euthanasia" program; as well as the ministry official Paul Werner (1900-1970), ${ }^{471}$ Deputy Director of the Reich Criminal Police Department, responsible for "preventative crime-fighting," "Gypsies," "juvenile delinquency" as well as concentration camps for juveniles, and who had assisted the "euthanasia" planning staff by procuring medications for the murder of patients. Justin's dissertation picked up directly on the debates about the "limits of educability" underway since the 1920s in the area of corrective training. She subjected Sinti children, who were accommodated in the Catholic St. Josefspflege home in Mulfingen/Württemberg, because their parents were interned (most of them in the concentration camps at Buchenwald and Ravensbrück), to "psychological" tests. On May 9, 1944, 2 months after Justin's dissertation appeard in print, the 39 children were deported to Auschwitz-Birkenau - only four survived. ${ }^{472}$

\footnotetext{
${ }^{469}$ Verschuer, Vier Jahre Frankfurter Universitätsinstitut.

${ }^{470}$ On the following: Gilsenbach, Lolitschai; Hohmann, Robert Ritter, pp. 238-271.

${ }^{471}$ For a biography: Klee, Personenlexikon, p. 670.

${ }^{472}$ On this also: Meister, "Zigeunerkinder."
} 
Also in 1943, Georg Wagner (" 1898$)^{473}$ submitted his dissertation about "Race Biology Observations on Gypsies and Gypsy Twins." The trained farmer had spent the years from 1923 to 1939 abroad, where he apparently worked as a correspondent for German newspapers and as a "nationalist political writer." In 1940 he began studying natural sciences at the University of Berlin. He must have joined up with Ritter's Research Office shortly thereafter, for the material upon which Wagner's dissertation was based had been collected in the framework of the total inventory of the Sinti and Roma in Germany and the occupied territories initiated by Ritter. As such, Wagner - like Eva Justin - was at the same time an employee of Ritter's Research Office and a doctoral student at the KWI-A. His doctoral research was advised by Verschuer, although Verschuer requested that Fischer step in as the official doctoral advisor for Wagner, whom he described as "a somewhat peculiar fellow." "474

In the introduction to his dissertation Wagner proudly remarked "that for the examinations of the probands around $14,000 \mathrm{~km}$ had to be traveled, and over 100 locations of the old Reich and the protectorate had to be visited." $475 \mathrm{He}$ had examined 209 persons and categorized them according to Ritter's classification system. He characterized the "pure Gypsies" as the descendants of the Aryans. Thus, Wagner was the right man for the SS Ahnenerbe, which was searching for a scientist to "research the Gypsy attributes derived from Aryans" in November 1943. On behalf of the Ahnenerbe and with the consent of Arthur Nebe (18941945), Head of the Reich Criminal Police Department until 1944, Wagner settled in Königsberg, intending to survey the "Gypsies" in Latvia, Estonia, Lithuania, and Finnland first, and to visit the "Gypsy settlements" in the Białystock district. Hence, Wagner, despite an unmistakable fondness for the "pure Gypsies," was party to creating the scientific foundations for the extermination of the Sinti and Roma. Wagner was still working on his research project in March/April 1945. On this Joachim S. Hohmann fittingly remarks, "Apparently Wagner was to merely record the evidence of life of an ethnic minority sentenced to extinction, before its genocide was completed. That he obstinately continued working on this just days before the end of the war is presumably one of the many paradoxes of the racist 'Third Reich'."'476

Wagner drew the attention of twin researchers to the Sinti and Roma, as he had examined 74 "Gypsy twins" himself as part of his dissertation, and had reached the conclusion that twin births occur nearly twice as often among Sinti and Roma than in the remaining population. ${ }^{477}$ Wagner reported to his colleague Karin Magnussen about "Gypsy twins" among whom he had noticed certain eye anomalies - Wagner's scientific curiosity brought these people directly to their death.

\footnotetext{
${ }^{473}$ On the following: Hohmann, Robert Ritter, pp. 281-286; Lösch, Rasse, pp. 383-387.

${ }^{474}$ Verschuer to Fischer, 9/3/1943, MPG Archive, Dept. III, Rep. 86 A (Münster), No. 9.

${ }^{475}$ Wagner, Beobachtungen, p. 1.

${ }^{476}$ Hohmann, Robert Ritter, p. 286.

${ }^{477}$ Wagner, Beobachtungen, pp. 56, 58, 61. Cf. Massin, Mengele, pp. $234 \mathrm{f}$.
} 


\subsubsection{Verschuer, Mengele, and the Interconnections Between Dahlem and Auschwitz.}

Josef Mengele, ${ }^{478}$ born in Günzburg, Bavaria in 1911 as son of an agricultural machinery manufacturer, studied medicine at the Universities of Munich and Bonn from 1929 to 1932. He passed the intermediate examinations to become a doctor in Bonn in 1932, before continuing his study of medicine, and now of anthropology as well, in Vienna and Munich. In 1935 he received his Ph.D. in Munich with a dissertation in the field of classical physical anthropology - on the morphology of the anterior section of the mandible in four racial groups. ${ }^{479}$ Mengele's doctoral advisor Theodor Mollison, Director of the Anthropological Institute of the University of Munich, one of the joint editors of the Archiv für Rassen- und Gesellschaftsbiologie and Chairman of the Munich Society for Race Hygiene, was one of the leading race hygienists of the Third Reich. He advocated an interlocking of race hygiene and race anthropology. Accordingly, at the course for psychiatrists organized by the German Research Institute for Psychiatry in January 1934, he warned against the "invasion of races of Asian origin" (with this he meant both "the yellow race" and "the Jews") ${ }^{480}$ to Europe. Mengele must have been just as well acquainted with his doctoral advisor's race policy positions as he was with Mollison's attempt to develop a serological race test using the "precipitine reaction" - more on this later.

In 1936 Mengele passed his state medical examinations and received his approbation as a physician in 1937. After a four-month internship at the University Clinic in Leipzig, in 1937 Mengele became an assistant at Verschuer's Frankfurt Institute for Genetic Biology and Race Hygiene. Here he took his second, medical Ph.D. with a dissertation about "family examinations in cases of cleft lip, cleft jaw, and cleft palate." ${ }^{\prime 81}$ Mengele proceeded from a group of 17 children with cleft lip, cleft jaw and cleft palate, who had undergone surgery at the Surgical Clinic of the University of Frankfurt/Main between 1925 and 1935. For these 17 children Mengele produced "family tables" covering a total of 1,222 "clan members," 583 of whom Mengele visited personally. He had the remainder examined by their local health offices. The genetic evaluation of the genealogical material, as Mengele summarized his results, made it possible "to recognize an irregular, singly dominant heredity of the disposition, whereby the manifestation depends on other developmental disorders" - among others, Mengele mentioned serious defects of the limbs, the lack of a closed spine and closed cranial bones, "as well as feeble-mindedness and mental disorders." ${ }^{482}$ In addition, Mengele established the frequent occurrence

\footnotetext{
${ }^{478}$ For a biography: Lifton, Ärzte, pp. 392-449; Zofka, Josef Mengele; Posner/Ware, Mengele; Roth, Normalität; idem., Josef Mengele; Kubica, Mengele; Völklein, Josef Mengele. On the "Auschwitz-Dahlem connection": Massin, Mengele; Trunk, Zweihundert Blutproben.

${ }^{479}$ Mengele, Untersuchungen des vorderen Unterkieferabschnittes.

${ }^{480}$ Mollison, Rassenkunde und Rassenhygiene, p. 44.

${ }^{481}$ Mengele, Sippenuntersuchungen.

${ }^{482}$ Ibid., pp. 23-25, 41 f., quotes: p. 42. Cf. also Massin, Mengele, pp. 209 f.
} 
in the families he examined of rudimentary forms of clefts in the area of the lips, the jaw and the palate, which suggested strong variations in the manifestation of the gene. Mengele's work made an important contribution to the elucidation of the disputed question as to the heredity of cleft lip, cleft jaw, and cleft palate, ${ }^{483}$ whereby the evidence of variations in manifestation fit in well with the recent findings of higher Mendelism. Moreover, the work was located in the area of arrested development malformations, in which a certain embryonic state of development remains intact, even when development ceases prematurely. Such arrested development malformations were of central interest under the aspect of phenogenetics, however - Mengele's later attachment to the KWI-A was due not only to his personal relationship with Verschuer, but also predisposed by his research emphasis.

The "cum laude" 484 dissertation met the scientific standards of the time and was published in 1939 in the renowned Zeitschrift für menschliche Vererbungs- und Konstitutionslehre. It immediately attracted considerable attention, not only on the national, but also on the international level, after Verschuer referred to Mengele's findings in his paper at the International Congress for Genetic Science in Edinburgh. ${ }^{485}$ Well into the 1960s Mengele's dissertation was well-received internationally and considered to be the standard work on its topic. ${ }^{486}$

Until 1941 Mengele published several short articles and reviews in Verschuer's journal Der Erbarzt ${ }^{487}$ Interesting to note is that he worked not only in the field of hereditary defects, but also undertook an excursion into neurology: after the death of the assistant Ottwil Reichert in 1939, Mengele completed Reichert's genealogical study "On the Heritability of Thrombangitis obliterans"(today: thrombangiitis obliterans, Winiwarter-Buerger disease), which was oriented toward the question of the heritability of rheumatism. ${ }^{488}$ Mengele also produced expert opinions in Frankfurt. Verschuer even entrusted him with the scientific evaluation of the comprehensive material that accrued in the "certificates of race and descent." ${ }^{399}$ In one case this yielded a short genealogical study on the heredity of Fistula auris congenita (branchiogenic syrinx, a special form of the cervical syrinx). ${ }^{490}$

\footnotetext{
${ }^{483}$ Mengele Sippenuntersuchungen, pp. 18-20.

${ }^{484}$ Massin, Mengele, p. 219.

${ }^{485}$ Verschuer, Bemerkungen zur Genanalyse, p. 67.

${ }^{486}$ Seidelman, Mengele Medicus, p. 604.

${ }^{487}$ For example, Mengele, Tagung der Gesellschaft für physische Anthropologie; idem., Review: Lothar Stengel von Rutkowski, Grundzüge der Erbkunde und Rassenpflege; idem., Review: Gerhard Venzmer, Erbmasse und Krankheit; idem., Review: Gottfried Pressler, Untersuchungen über den Einfluß der Großstadt; idem., Review: Georg von Knorre, Vererbung angeborener Herzfehler.

${ }^{488}$ Reichert, Erbbedingtheit, p. 53 (note 1): "Completed and published by Dr. J. Mengele after the death of Ottwil Reichert." On the discussions about the naming of this disease in the Third Reich, cf. Schmuhl, Ärzte in der Westfälischen Diakonissenanstalt Sarepta, pp. $72 \mathrm{f}$.

${ }^{489}$ By January 1941 Verschuer and his staff had produced 448 paternity opinions. Verschuer, Vaterschaftsgutachten, pp. $25 \mathrm{f}$. Cf. also idem., Vaterschaftsbestimmung.

${ }^{490}$ Mengele, Vererbung der Ohrfisteln.
} 
Whether Mengele was actually Verschuer's "pet pupil," 491 as Hans Grebe asserted in the 1980s, remains to be seen. Certainly Verschuer saw in Mengele great promise for the future. It was Verschuer's suggestion that Mengele attend the International Congress for Anthropology and Ethnology in Copenhagen in 1938, and the International Congress for Genetics in Edinburgh in $1939^{492}$ - and that in both cases Mengele was not able to participate was due to foreign exchange difficulties, but changed nothing about Verschuer's special esteem, which left no doubt that the young scientists included in his list of proposals were the only ones who came into question for him as future university instructors. ${ }^{493}$ The judgement of Benoît Massin, that Mengele, had there been no war or had Germany not lost the war, in all probability would have made the leap to a professorial chair - like his associates in Frankfurt, Ferdinand Claußen, Heinrich Schade, and Hans Grebe - must be confirmed wholeheartedly. ${ }^{494}$

It was probably Mengele's tremendous ambition that led him into the temptation to take a shortcut against the background of World War II to drive his career forward more quickly and further than his associates, by unscrupulously taking advantage of the unfettered access opened up to him by the world of the National Socialist camps. His close connections to the SS constituted free admission to this world. From 1931 to 1934 Mengele was a member of the Stahlhelm; after this organization was subsumed by the SA he remained a member until October 1934. In 1937 he joined the NSDAP, in 1938, the SS. Called up to the Wehrmacht in 1940, Mengele volunteered for the Waffen-SS, where he was assigned to the Medical Corps Inspection Office. In November 1940 he was transferred to the RuSHA, where he worked in Department II of the Family Office, responsible for "care of genetic health" and "genetic health tests." ${ }^{495}$ What his job was and where he was deployed has yet to be clarified conclusively. Presumably, for a time at least, he wrote expert opinions about the "Germanizationability" of "German national" resettlers at an office of the Reich Commissioner for the Fortification of German Volkstum in Posen. ${ }^{496}$

In late 1941/early $1942^{497}$ Mengele was sent to the eastern front with the SS Division "Viking," after he had been promoted from SS-Untersturmführer (lieutenant)

\footnotetext{
${ }^{491}$ Quoted in Müller-Hill, Tödliche Wissenschaft, p. 158.

${ }^{492}$ Massin, Mengele, p. 221. Extensive documents in: BArch. Berlin, R 4901/3016.

${ }^{493}$ Massin, Mengele, p. 221.

${ }^{494}$ Ibid., pp. $221 \mathrm{f}$.

${ }^{495}$ Sanitätsinspektion der Waffen-SS to RuSHA, 5/11/1940, BArch. Berlin, BDC, SSO Mengele, p. 403.

${ }^{496}$ Such the portrayal by Zofka, Josef Mengele, p. 254, and Völklein, Josef Mengele, pp. $90 \mathrm{f}$,, which was not documented, however. Heinemann, "Rasse," p. 626, states - here, too, without any proof - that Mengele's job at the RuSHA predominantly concerned the "genetic health examination" of candidates for the SS, but that he was detached to Posen for a short period to evaluate the racial status of "German nationals." Cf. Trunk, Zweihundert Blutproben, pp. 12f., which, however, also believes that Mengele was temporarily employed in this function in Posen.

${ }^{497}$ The central file card in Mengele's personnel file as an SS officer lists January 1942. In the recommendation for promotion of 24/11/1941, however Mengele, was already designated as "physician SS Viking Division.” BArch. Berlin, BDC, SSO Mengele, p. 395, 405.
} 
to Obersturmführer (1st Lieutenant). During his military deployment he received the Iron Cross, 2nd and 1st class, the Eastern Campaign 41/42 Medal and the Kriegsverwundetenkreuz (Germany's Purple Heart), 2nd class with swords. In July 1942 - probably due to a wound - Mengele was transferred to the office of the "Reich Physician SS and Police" Ernst Grawitz in Berlin, ${ }^{498}$ i.e. to the office responsible for oversight of the concentration camps and the human experiments performed there. It is questionable whether he actually reported for service there, however, for he apparently remained with the "Viking" division - perhaps he was posted to the "Viking" Division by the Reich Physician SS and Police. In any case he was still on the rolls of this unit as physician for the troops in October 1942 and recommended for a further promotion. ${ }^{499} \mathrm{He}$ also participated in the Battle of Stalingrad. ${ }^{500}$ As proceeds from a letter by Verschuer to Fischer of January 25, 1943, Mengele did not return to Berlin until early 1943:

A few days ago my assistant Mengele flew 2 days long from Salsk [a city east of Rostow on the Don] to Germany. He took part in all of the battles with the SS division Viking, was decorated with the Iron Cross and has been transferred to an office here in Berlin for the time being, so that he can also be active at the institute in addition to his duties there. ${ }^{501}$

In February 1943 Mengele was assigned to the SS infantry substitute batallion "East," which was stationed in Berlin. He used his time in Berlin - from late January to late May 1943 - to consolidate his relationship with his doctoral advisor Verschuer. As mentioned above, Verschuer already had the intention of bringing Mengele to Dahlem once he had established himself there. At the institute Mengele was apparently regarded as a guest scholar, although he did not sign a regular employment contract with the KWG. His name appeared on an internal list of birthdays, apparently as a matter of course. ${ }^{502}$ As also mentioned above, Verschuer again entrusted him with expert opinions. ${ }^{503}$ However, the official version was that Mengele was on combat leave from the University of Frankfurt/Main until the end of the war - the position as a regular assistant under Verschuer's successor Heinrich

\footnotetext{
${ }^{498}$ Personnel command of 17/7/1942 (signed by Siegfried Liebau), ibid., p. 406.

${ }^{499}$ Recommendation for promotion of $13 / 10 / 1942$ by Battallion Commander Schäfer of SS Pioneer Dept. 5, a sub-division of the SS Division "Viking," ibid., p. 412.

${ }^{500}$ Mengele was not deployed in Stalingrad (as stated in Kröner, Von der Rassenhygiene zur Humangenetik, p. 53), but took part in the battles around Stalingrad.

${ }^{501}$ Verschuer to Fischer, 25/1/1943, MPG Archive, Dept. III, Rep. 86 A (Münster), No. 9. Verschuer continued: "He [Mengele] accounted very interestingly that the entire disaster came about to the right and left of Stalingrad through a collapse of the Romanian Army. The officers ran away and left their soldiers in the lurch. Thus in the end everything degenerated into chaotic flight. Several German tank divisions then stuck into this confusion, but they were forced to retreat in the face of immense Russian superiority." - In his response of February 2, 1943 Fischer remarked, "I am very happy for you that you have Mr. Mengele, at least part time." Fischer to Verschuer, 2/2/1943, ibid.

${ }^{502}$ Reprinted as a facsimile in Müller-Hill, Blut, p. 197.

${ }^{503}$ Verschuer to the KWG, 29/6/1943, MPG Archive, Dept. I, Rep. 1 A, No. 577.
} 
Wilhelm Kranz was reserved for him. ${ }^{504}$ Nevertheless one may presume that Mengele saw his future in Berlin. Verschuer certainly regarded him as a candidate for professorship, and it probably can be assumed that the two discussed possible topics for his postdoctoral dissertation during Mengele's stay in Berlin.

On May 24, 1943 Mengele, who had been promoted to captain of the reserves of the Waffen-SS shortly before, was transferred effective May 30, 1943 to the SS Main Economic and Administration Office, Group D III (Medical Care and Camp Hygiene for Concentration Camps) and sent to the Auschwitz concentration and extermination camp, ${ }^{505}$ where he worked as Executive Camp Physician in the "Gypsy camp" (Section B II e Auschwitz-Birkenau). ${ }^{506}$ Whether Mengele was assigned to Auschwitz through no fault of his own, or, as Verschuer claimed after the war, against his will, ${ }^{507}$ or whether, on the contrary, he took steps himself to effect a transfer to Auschwitz, and whether Verschuer pulled some strings ${ }^{508}-$ these questions cannot be answered conclusively based on today's state of knowledge. Ulrich Völklein argues that Mengele ended up in Auschwitz more or less by coincidence: The SS physician initially assigned to the "Gypsy camp" at AuschwitzBirkenau, Benno Adolph (1912-1967), had fallen ill with scarlet fever in April 1943 and was unable to work until November 1943 - thus a short-term replacement was sought, and Mengele was available at the time. Völklein can support his argumentation with the fact that Mengele's transfer orders expressly noted "Reference: None." 509 This can be assessed as a certain indication that no written transactions existed. In other words: A voluntary enlistment by Mengele in written form was in all probability not submitted. But this was not absolutely necessary. It cannot be excluded that Mengele - possibly with Verschuer's support - contrived behind the scenes for a transfer to Auschwitz. This is the gist of Benoît Massin's argument, whereby he assigns a key role to Siegfried Liebau and even alleges that there was an "alliance between Verschuer and the SS" arranged by Liebau. ${ }^{510}$ It is documented

\footnotetext{
${ }^{504} \mathrm{Cf}$. excerpts from the course catalog of the University of Frankfurt in Koch, Humangenetik, pp. $130 \mathrm{f}$. - Koch believes it is possible that Mengele wanted to keep open his options for qualifying as a professor in Frankfurt (ibid., p. 133). There is no evidence of collaboration between Mengele and Kranz, however. It is much more probable that Mengele wanted to qualify under Verschuer. ${ }^{505}$ SS-Führungshauptamt to WVHA, 24/5/1943, BArch. Berlin, BDC, SSO Mengele, p. 409.

${ }^{506}$ From August to November 1944 Mengele also held the position of $1^{\text {st }}$ Camp Physician of the Auschwitz II-Birkenau concentration camp. After the re-integration of the Auschwitz II camp into the main camp in November 1944 he became Executive Camp Physician in the men's hospital area B II f. Kubica, pp. 377 f.; Lasik, p. 314.

${ }^{507}$ Verschuer, Stellungnahme zu den Angaben, die sich auf meine Person beziehen und in der "Neuen Zeitung" Nr. 35 vom 3.5.1946 unter der Rubrik "Kunst und Kultur in Kürze" in der Notiz "Vertriebene Wissenschaft" erschienen sind, Archives of the University of Frankfurt/Main, Dept. 13, No. 347, p. $178 \mathrm{f}$.

${ }^{508}$ Thus, e.g. Zofka, Josef Mengele, p. 255; Posner/Ware, Mengele, p. 37; and quite emphatically: Massin, Mengele, pp. 224-233.

${ }^{509}$ Völklein, Josef Mengele, p. 92.

${ }^{510}$ Massin, Mengele, p. 228.
} 
that Liebau, in his capacity as head of the personnel division in the Office of the Waffen-SS Medical Corps, signed the order of July 17, 1942 which provided for Mengele's transfer from the "Viking" division to the "Reich Physician SS and Police." Also documented is the fact that Liebau, at Verschuer's request, was detached to the KWI-A for specialized training from December 1942 to October 1943 and thus present there in the period when Mengele was a regular guest at the institute. Finally, it is also documented that Liebau spent the first half of 1943 there - before Mengele's transfer to Auschwitz - and brought with him photographs of a "Gypsy clan" with heterochromous eyes for Karin Magnussen. Massin finds support for his theory in a statement by Hans Münch (1911-2001), who was the Director of the SS Hygiene Institute in Auschwitz from 1943 to 1945 and worked closely with Mengele in this capacity. Münch, as he stressed later in an interview with Robert Jay Lifton, had the impression that Mengele had "requested his transfer to Auschwitz, apparently because of the great research possibilities." 511

Münch further testified that Mengele had worked on a postdoctoral project in Auschwitz - and this claim, regardless of how Mengele ended up at Auschwitz, can arrogate a high degree of probability. In retrospect Münch described Mengele's mentality with the words, "it would be a sin, it would be crime ... that it was irresponsible not to take advantage of the opportunity presented by twin research in Auschwitz. If they were going to be gased anyway ... This comes around only once, this chance." 512 Regardless of whether Mengele caught wind of this chance on the basis of information from the office of the "Reich Physician SS and Police" and thus actively instigated his transfer to Auschwitz, or whether he did not recognize this chance until he reported for duty - it is clear that Mengele unscrupulously exploited the opportunities presented to him there. Before long he built up his own research empire. From among the prisoners, he recruited a group of medical specialists for pathology, pediatrics, gynecology, ophthamology, ear, nose and throat medicine, and dentistry, along with technical assistants, nurses, kindergarden and nursery-school teachers, and secretaries. Mengele's laboratory barracks in the "Gypsy camp" - after its liquidation the laboratory was moved to Block 15 in Section B II f of the camp - was directed by the internationally respected pediatrician Berthold Epstein (1890-1962) from the University of Prague, supported by Charles Sigismund Bendel from the University of Paris. For the analysis of blood, urine, feces, saliva and tissue, Mengele had the SS Hygiene Institute in Rajsko at his disposal. ${ }^{513}$ But above all, the selection of new arrivals on the platform gave him unlimited possibilities to access humans completely devoid of rights and protection. From the endless stream of deportation trains he could single out any human "guinea pigs" he pleased - Jews, "Gypsies" and other "alien nationals," people with

\footnotetext{
${ }^{511}$ So Lifton paraphrased Münch's testimony. Lifton, Ärzte, p. 398.

${ }^{512}$ Quoted in ibid., p. 418 (original omissions). This also explains Mengele's obsession, who - in contrast to his colleagues - often came to the platform even when he was not on duty. Ibid., pp. 399-401.

${ }^{513} \mathrm{Cf}$. Kieta, Hygiene-Institut.
} 
physical anomalies, entire families ${ }^{514}$ and, best of all, twins. Mengele created a "twin camp" in Auschwitz, the sheer population of which exploded all dimensions previously known. The exact number of twin pairs that fell into his hands in Auschwitz is unknown - Massin estimates that at least 900 children went through Mengele's "twin camp." 515 Moreover, twin research under the conditions of the Auschwitz concentration and extermination camp presented the unique opportunity to supplement the clinical and anthropological examination of twins with the pathological examination of their corpses, as Mengele could murder, or have murdered, both twins at any time. Miklós Nyiszli already pointed out this circumstance:

An event never before experienced in the history of medicine worldwide is realized here: Twins die at the same time, and there is the possibility of subjecting their corpses to an autopsy. Where in normal life is there the case, bordering on a miracle, that twins die at the same place at the same time? [...] A comparative autopsy is thus absolutely impossible under normal conditions. But in the Auschwitz camp there are several hundred pairs of twins, and their deaths, in turn, present several hundred opportunities! $!^{516}$

Massin characterizes Mengele's research empire at Auschwitz as the "Auschwitz Branch Office" 517 of the KWI-A. I find this analysis problematic for two reasons. First, it suggests a formal institutional connection, which certainly did not exist in this form - Mengele's position in Auschwitz did not at all correspond to Diehl's position in Sommerfeld. Secondly, Massin's interpretation constructs all too great a dependence of Mengele's on Verschuer. Certainly: Mengele's interests in twin research, in chondrodysplasia, in physical defects and in eye anomalies were oriented toward the model of the Frankfurt Institute for Genetic Biology and Race Hygiene, according to which the institute in Dahlem was also reorganized from 1943 on. Even his interest in Noma facies (gangrenous stomatitis, water cancer), a rare deficiency disease caused by extreme hunger, which raged among the children in the "Gypsy camp," presumably had a genetic pathology background. In this case Mengele probably continued with his mentor Verschuer's research strategy of scrutinizing all kinds of forms of disorders - from cancer to tuberculosis, to diabetes, to diptheria, and pneumoconiosis - to see if they were hereditary. This orientation is ultimately not surprising. Mengele shaped his own research empire in accordance with the institutes at which he had worked before, but in Auschwitz he was his own master.

On the other hand it is indisputable that Mengele, at his outpost in the no-man's-land of the world of National Socialist camps, was interested in being integrated into the scientific community and sought contact and collaboration with other scientists and research institutions - consider, for instance, his pharmacological investigations for

\footnotetext{
${ }^{514}$ Massin, Mengele, p. 234, points out that Auschwitz, in contrast to all other concentration camps, had sections of the camp in which entire families were imprisoned together: the "Gypsy camp" (from February 1943 until late July 1944) with around 23,000 inmates and the "family camp" for the Jews from the Theresienstadt ghetto (from September 1943 to July 1944) with more than 18,000 inmates. This was an essential aspect for a scientist interested in "family research."

${ }^{515}$ Ibid., pp. 235 f.

${ }^{516}$ Nyiszli, Jenseits, p. 42. Cf. Massin, Mengele, pp. 210-217.

${ }^{517}$ Massin, Mengele, p. 236.
} 
I.G. Farben. ${ }^{518}$ His most important cooperation partners by far, however, were and remained Verschuer and his group of researchers in Dahlem (all the more so if the assumption is correct that Mengele intended to write his postdoctorate dissertation under Verschuer). In any case Mengele upheld contact with Verschuer from Auschwitz, and paid at least one visit to the institute in Dahlem during this time - in his memoirs based on his diary of the time, Gerhard Koch reports meeting Mengele sometime around July 1943 in the KWI-A library. ${ }^{519}$ In at least two cases this contact resulted in concrete collaboration: In the first case, in 1943/44, Mengele delivered the heterochromous pairs of eyes belonging to several members of a Sinti family to Karin Magnussen, on the other, between October 1943 and März 1944, he joined in Verschuer's "Specific Proteins" project, providing his mentor with around 200 blood samples from persons of various races. As the prisoners' physician Miklós Nyiszli reported, Mengele was also interested in inmates with growth anomalies ("dwarfism" or "gigantism") or physical defects. According to Nyiszli, Mengele picked out such persons during the selections on the platform, and then had his assistants examine, kill and dissect them. Mengele ordered that some of the specimens obtained from these autopsies be sent to Dahlem:

The scientifically interesting parts of the corpse are preserved, so that Dr. Mengele can take
a look at them. I have to keep anything that could be of interest to the institute in Dahlem.
These specimens then come into a package for the journey, and a special stamp sees to it that
it is dispatched more quickly: 'Urgent, contents of strategic importance for the war.' During
my stay at the crematorium I expedited countless packets of this kind to Berlin-Dahlem, in
response to which extensive replies with scientific opinions or instructions came in. I put
together a special dossier for the purpose of storing this correspondence. For the rare materi-
als we sent, the institute almost always expressed its deepest thanks to Dr. Mengele. ${ }^{520}$

Elsewhere Nyiszli depicts the case of two Jews, father and son, who were deported to Auschwitz on a train from the Łódž ghetto and had piqued Mengele's scientific interest. The father suffered from scoliosis as a long-term consequence of rachitis, the son from hypomelia (a disorder that affects the development of the limbs). After a clinical examination, Mengele had them murdered and commanded that "the skeletons [must be] dissected and sent to the Anthropological Museum in Berlin'., On the basis of this testimony, the authenticity of which is estimated to be very high, there is the suspicion that Mengele's deliveries to Dahlem took place on a large scale, and that not only eyes and blood, but also internal organs and skeletons found their way to the KWI-A. The most likely recipients are Hans Grebe and Wolfgang Abel: Grebe as a specialist for chondrodysplasia and physical defects, ${ }^{522}$ Abel with his plan for an "instructive collection for the race history of Europe."

\footnotetext{
${ }^{518}$ On this, the letter by Wilhelm R. Mann, the director of I.G. Farben, to Verschuer, in: Koch, Menschen-Versuche, p. 179 (without annotation of its source).

${ }^{519}$ Koch, Humangenetik, p. 130.

${ }^{520}$ Nyiszli, Jenseits, pp. $45 \mathrm{f}$.

${ }^{521}$ Ibid., pp. 123-128, quote: p. 126.

${ }^{522}$ Müller-Hill, Blut, p. 205, writes, one can "presume" that the specimens ended up on Grebe's desk. It must be emphasized that this is merely a justified suspicion. Also along these lines: Klee, Auschwitz, p. 473.
} 
In addition to Mengele, two other scientists connected with Verschuer's institute worked at Auschwitz. One of them was Siegfried Liebau, who performed research on "Gypsy" twins in Auschwitz during the period when he was detached to Dahlem for further training - as mentioned above, he may have been the one who initiated the contact to Auschwitz and arranged for Mengele's transfer there. The other was the SS-Obersturmführer and physician at the SS military hospital in BerlinLichterfelde, Erwin von Helmersen (1914-1949), who took his doctorate with Fritz Lenz in August 1943, with a dissertation on "The Descendants of an Armenian Family in a Village of the Bukovina Settled by Germans." 523 Helmersen had been listed as a doctoral student since 1942, and thus was connected with the KWI-A at the same time Mengele was spending time as guest scholar there. After receiving his Ph.D., followed by a short assignment in the Oranienburg concentration camp, Helmersen went to Auschwitz, where he worked as camp physician in the "Gypsy camp" in section B II e and in the prisoners' hospital B II f. Helmersen, who was also involved in medical experiments at Auschwitz, was thus one of Mengele's subordinates for a time. ${ }^{524}$

Consequently, a network of lines emerge connecting Dahlem and Auschwitz, which cannot yet be tracked down into its finest nooks and crannies on the basis of the contemporary state of research. Clear is that Magnussen received from Mengele a series of pairs of eyes for her "eye color" project, and Verschuer around 200 blood samples for his "specific proteins" project. It is also clear that the two "not only knew of the provenance of these specimens, but that, in this knowledge, they used their contact to Mengele in order to obtain these specimens." ${ }^{525}$ What is not clear, however, is the question as to whether they knew under what circumstances and in what manner the specimens were extracted in Auschwitz. During interrogation by the American military authorities on May 13, 1947, Verschuer denied that he had known about the events in Auschwitz, but did admit to having heard the rumors abounding at the time. During a visit by Mengele, Verschuer testified further, he had asked Mengele "just to explain if there was actually anything true about these rumors." In response Mengele had reported "about factories located there, his camp hospital, the excellent harmony that existed between him and his patients." "He knew absolutely nothing about inhuman treatment or any other kinds of atrocities." ${ }^{526}$ Whether Mengele completely denied the industrially mass murder perpetrated in Auschwitz, or simply let the matter rest with these sinister intimidations, ${ }^{527}$ it is highly improbable that he confronted his collaborative partners at the KWI-A with the whole truth.

\footnotetext{
${ }^{523}$ Helmersen, Nachkommenschaft. Cf. also Lösch, Rasse, p. 379.

${ }^{524}$ Lasik, Personalbesetzung, pp. $307 \mathrm{f}$.

${ }^{525}$ Sachse/Massin, Forschung, pp. 24.

${ }^{526}$ Quoted in Kröner, Von der Rassenhygiene zur Humangenetik, p. 129.

${ }^{527}$ In an interview with Benno Müller-Hill, Verschuer's son Helmut recalls that his mother had told him about dining with Mengele in Berlin. In response to her inquiry, Mengele is supposed to have replied that his job in Auschwitz was "horrible," but that he could not talk about it. MüllerHill, Tödliche Wissenschaft, p. 129.
} 
However, it can also be assumed that they did not harry him to do so. They certainly knew enough to not want to know more. In general it can be said - with all due reservations - that only a few Germans knew everything about the "Final Solution," but likewise, only very few knew nothing at all. Those working at the KWI-A certainly did not know everything, but quite a bit indeed: "In hardly any other scientific institution in Germany," in the judgement of Carola Sachse and Benoît Massin fittingly, "could access to knowledge about the crimes in Auschwitz have been so easy [...]." 528 As discussed extensively elsewhere, the genocidal character of the "total solution of the Jewish question" must have been altogether clear to Fischer and Verschuer. Further, Fischer was familiar with the details of the Generalplan Ost, for which the extermination of the eastern European Jews was a prerequisite. Beyond this, the KWI-A enjoyed excellent connections to the RuSHA through Herbert Grohmann, Günther Brandt and Helmut Thieme. At least two scientists who worked at the KWI-A, Harry Suchalla and Christian Schnecke, knew about the crimes against Jews in occupied Łódź. Siegfried Liebau, Josef Mengele, and Erich von Helmersen amounted to three scientists with contact to the KWI-A who actually worked at Auschwitz. Wolfgang Abel, too, had indirect contacts at Auschwitz, and perhaps at the Sachsenhausen concentration camp as well, but in any case he had insight into the stalags for Soviet prisoners of war.

\subsubsection{Karin Magnussen and the Project on Heterochromia}

Karin Magnussen was born in Bremen in $1908 .{ }^{529}$ Her mother was a sculptor, her father a teacher at the Bremen School for Applied Arts. After graduating from secondary school, in 1928 she began studying biology, chemistry, geology, and physics - still quite unusual for a woman at the time - at the University of Göttingen. In 1929 she spent two semesters at the University of Freiburg, where she was influenced above all by the lectures of the developmental physiologist Hans Spemann. In 1932, back in Göttingen, she took her doctoral examinations in the subjects zoology, botany, and geology. Her dissertation, entitled Untersuchungen zur Entwicklungsphysiologie des Schmetterlingsflügels ("Studies on the Developmental Physiology of the Butterfly Wing") was advised by Alfred Kühn and published in 1933. This work concerned artificially induced defects in the rudimentary origins of the organs in caterpillars and their effects on the patterns and pigmentation of the fully developed butterfly wing - the influence of Spemann and Kühn is obvious. ${ }^{530}$

Göttingen had been a stronghold of National Socialism of the first hour, and the student body in Göttingen was particularly involved in the earliest successes of the NSDAP in the university town. ${ }^{531}$ Walter Groß, who had been involved in the very

\footnotetext{
${ }^{528}$ Sachse/Massin, Forschung, p. 26.

${ }^{529}$ For the basics on the following: Hesse, Augen, pp. 32-46; Klee, Medizin, pp. 357-371.

${ }^{530}$ Magnussen, Untersuchungen zur Entwicklungsphysiologie.

${ }^{531}$ Tollmien, Nationalsozialismus in Göttingen; Dahms, Universität Göttingen, p. 408.
} 
founding of the Göttingen branch of the NSDAP back in 1922, one of the first in northern Germany, established a university group of the National Socialist League of German Students (Nationalsozialistischer Deutscher Studentenbund) in Göttingen in 1926/27. The students in Göttingen who were active in the party included Rudolf Mentzel - as District Leader of the NSDAP ${ }^{532}$-, who became president of the German Research Association in 1937; and Achim Gercke, the organizer of the "Archive for Race Science Statistics on Professions" (Archiv für rassenkundliche Berufsstatistik) who later became "Race Science Expert" (Sachverständiger für Rasseforschung) to the Reich Minister of the Interior before advancing to the top of the Reich Genealogical Office. Magnussen found admittance to this network during her days as a student in Göttingen. In 1931 she became a member of the NSDAP - this, too, highly unusal for a woman, as only very few women joined the party at this time $\mathrm{e}^{533}$ - and was active in the National Socialist League of German Students. Her associates later remember that Magnussen had attracted notice in Göttingen as a "fanatic National Socialist." "534 After the Nazis took power she resolutely pursued her party career. In 1934 she became a member of the BDM, for which she held training lectures about race and demographic issues in the district of Bremen. From 1935 on she was also an employee of the Race Policy Office of the NSDAP in the district of Hanover.

Magnussen apparently also had contact with the Bremen branch of the German Society for Race Hygiene under its chairman, the lecturer Hans Duncker (18811961) since the Weimar Republic. ${ }^{535}$ In this framework, Magnussen may even have experienced the greats of Weimar Eugenics first hand - Fritz Lenz, Hermann Muckermann, Eugen Fischer, and Otmar von Verschuer - all of whom held lectures to the Bremen branch. ${ }^{536}$

There is no doubt that Karin Magnussen was a fervent National Socialist, race hygienist and anti-Semite. In 1936 - barely 27 years of age - she published her 150-page book Rassen- und bevölkerungspolitisches Rüstzeug ("The Munition of Race Policy and Population Policy"). The third edition appeared in 1943, now swollen to 230 pages. The tract, which propagated "population statistical and race statistical material" and discussed relevant "legislative measures," was conceived - as stated in the preface to the first edition - as an overview for "biology teachers and trainers for instruction in the graduating classes and for race biology training." 537 In 1943 the author designated the solution of the "Jewish question" as the "core racial problem in Europe":

From the European standpoint the Jewish question is not solved by the circumstance that Jews emigrate from the racially thinking states to the other states. We see that these

\footnotetext{
${ }^{532}$ Popplow, Machtergreifung, p. 180.

${ }^{533}$ Only $5-8 \%$ of the new members of the NSDAP before 1933 were women. Cf. Falter, Hitlers Wähler, pp. $146 \mathrm{f}$.

${ }^{534}$ So Georg Melchers (1906-1997) in an interview with Müller-Hill, Tödliche Wissenschaft, p. 164. ${ }^{535}$ Nitschke, "Erbpolizei," esp. pp. 63 ff., 79, 89 ff.

${ }^{536}$ Also Walter Groß and the later "Gypsy researcher" Robert Ritter held lectures there.

${ }^{537}$ Quoted here in: Magnussen, Rüstzeug, 3rd edn. p. 5. Hesse, Augen, pp. 45 f., presumes that this was a "contracted work," arranged by the director of the Race Policy Office, Walter Groß.
} 
emigrants merely breed unrest and incite the Völker ("nations") against each other. [...] The race policy goal of this struggle of nations thus must be: The spatial separation of the European races and nations from all aliens (Jews, Gypsies, Negroes) [...]. ${ }^{538}$

With her book Magnussen supplied an apparent basis of scientific legitimation to the National Socialists' gigantic deportation program, which reckoned with the decimation of the deported from the very outset.

In December 1933 Magnussen passed the state examinations for secondaryschool education in the subjects biology, chemistry, and geology and began teaching. Her last position - from 1939 to 1941 - was as a secondary school teacher in Hanover, in line for a civil service post. On September 15, 1941 she began her work at the Department for Experimental Genetic Pathology at the KWI-A - initially as a scholarship student. None of the details of the circumstances of her hiring are known. Hans Hesse conjectures that she was hired "because of her old connections and early party membership." Walter Groß, whom she knew well from her days in Göttingen, had played an important role on the Board of Trustees of the KWI-A since 1935, as discussed previously. Hesse further assumes that the drafting of male employees to the Wehrmacht had created gaps in the scientific staff that were difficult to close, so that Eugen Fischer had been forced to appoint a "woman and not particularly established scientist." 539 This thesis can be concurred with only in part. That political protection played a role in Magnussen's appointment may well be true. That a woman was hired and entrusted with a research project central to the conception of the institute, however, was not as rare an exception as Hesse apparently assumes, even before 1939 - remember Rita Hauschild. What is least true of all is the assumption that Karin Magnussen was not sufficiently qualified for her post at the KWI-A. True: She had worked 8 years as a teacher, far removed from research. But for Eugen Fischer she was nevertheless a very interesting candidate especially against the background of the paradigm shift to phenogenetics: The complex interplay of genes and environmental factors in the pigmentation of the iris constituted one of the central research fields in Fischer's conception of phenogenetics, and he oriented his focus above all on Alfred Kühn's and Adolf Butenandt's research on the flour moth Ephestia. A pupil of Kühn, Magnussen had worked on the influence of genes and pharmacologically effective agents on eye color, and after earning her Ph.D. in July 1932 with Butenandt as her advisor, worked on pituitary hormones. ${ }^{540}$ According to later testimony by Magnussen, back in 1938 she was already researching the pigmentation of the eyes, and the phenomenon of heterochromia (the occurrence of two irises with different colors) in particular. In other words: Magnussen was well-versed in a research field that was of the greatest interest to Fischer in the course of restructuring his institute, and she had collaborated with the researchers to whom he had sought closer contact since 1938.

\footnotetext{
${ }^{538}$ Magnussen, Rüstzeug, 3rd edn., pp. $202 \mathrm{f}$.

${ }^{539}$ Hesse, Augen, p. 46.

${ }^{540}$ Moreover, as a student in Freiburg she had also learned from Hans Spemann the techniques of producing, dyeing and embedding microtome cuts.
} 
The new institute director Otmar von Verschuer also thought the world of Magnussen, and gave her an assistantship in November 1943, when she was unable to extend her leave from the school system. ${ }^{541}$ From that point on, Magnussen was listed in Nachtsheim's official reports as a staff member of his Department for Experimental Genetic Pathology, but Nachtsheim neither went into her research in his annual report of 1943/44, nor did he include her works in the list of publications from his department ${ }^{542}$ - Verschuer did this instead in his own report. It seems that Nachtsheim and Magnussen followed different paths in their research, ${ }^{543}$ although Magnussen took up work in one of Nachtsheim's main areas of research - in fact, she started at the KWI-A shortly after Nachtsheim's eye research had begun stagnating as a consequence of his collaboration partner Hellmuth Gürich's being drafted. There are also numerous potential points of contact: both used rabbits as their animal model, both were interested in the pigmentation of the rabbit eye (Nachtsheim's “epileptic" Vienna Whites had blue eyes as a consequence of a pigment deficiency), both directed their attention to the effects of the aging process on genetic attributes. Yet their research projects, as far as we can tell, proceeded in parallel and without any connection: Nachtsheim worked on genetic pathology in the strictest sense, while Magnussen understood her work as a contribution to the phenogenetics of normal attributes. Nachtsheim stated after the war that he had not wanted to work with Magnussen because of her political views. He also claimed to know about her connections to Auschwitz, which was the "greatest shock" 544 he experienced during the Third Reich.

In three of Magnussen's progress reports of September 1943, March and October 1944, the contours of the research project "On the Investigation of the Heritability of the Development of Eye Color as the Basis for Examinations of Race and Descent" 545 became clear, which covered six different, clearly demarcated subareas:

First, in preparation for all other subareas, as it were, Magnussen dealt with methodological questions on the determination of the structure, color, and pigment distribution of the human iris. She published the results of this work in 1943 in Der Erbarzt. ${ }^{546}$ This clarification of preliminary methodological questions pertained directly to application: "In the paternity expert opinions, new experiences are being collected constantly and already obtained experience evaluated." 547 In the very

\footnotetext{
${ }^{541}$ Verschuer to Fischer, 13/11/1943, MPG Archive, Dept. III, Rep. 86 A (Münster), No. 9.

${ }^{542}$ Cf. Unterlagen der Abteilung für experimentelle Erbpathologie für den Jahresbericht [1943/44], MPG Archive, Dept. I, Rep. 3, No. 22.

${ }^{543}$ As such: Schwerin, Experimentalisierung, pp. 270-273.

${ }^{544}$ Nachtsheim to L. Dunn, 14/2/1961, MPG Archive, Dept. I, Rep. 20 A, No. 22.

${ }^{545}$ Magnussen, Bericht über die Durchführung der Arbeiten zur Erforschung der Erbbedingtheit der Entwicklung der Augenfarbe als Grundlage für Rassen- und Abstammungsgutachten, 24/9/1943, BArch. Koblenz, R 73/15.342, p. 69.

${ }^{546}$ Magnussen, Bestimmung der Irisstruktur; idem., Bestimmung der Farbe.

${ }^{547}$ Magnussen, Bericht über die Durchführung der Arbeiten zur Erforschung der Erbbedingtheit der Entwicklung der Augenfarbe als Grundlage für Rassen- und Abstammungsgutachten, 13/3/1944, BArch. Koblenz, R 73/15.342, p. 68.
} 
heading of her first research report Magnussen had emphasized that her research, as applied genetics, was of importance for the praxis of National Socialist race policy. It can be presumed that in Magnussen's case this was more than the rhetoric necessary to get a research application approved, and that she placed her research at the service of National Socialist race policy out of true conviction. But this was only one side of the coin: her research on eye pigmentation was also, and above all, conceived of as theoretical research, as an important building block of phenogenetics.

Second, Magnussen bred strains of rabbits with certain eye colors "for the purpose of determining the influence of certain hereditary dispositions on eye pigmentation." The animals were under constant observation so that the development of pigmentation could be followed over time. From the report of October 1944 it is clear that Magnussen was also busy with "breeding for the investigation of heterochromia." ${ }^{548}$

Third, Magnussen performed experiments on rabbits "to physiologically influence pigment development." This project was initially delayed by the war. "The series of experiments planned," Magnussen reported in September 1943, "could not be performed, since the compound required, which is manufactured in Hamburg, was lost in the terrible attack [...]." 549 In October 1944 Magnussen was able to report on the first results of these experiments:

During the main breeding period in the summer months, several series of examinations on the physiology of pigment development were performed, in which the action of several hormones and pharmacologically effective substances on the development of pigment in the eyes of different races was studied. Here certain races whose pigment development showed certain similarities with that of humans, the influence of such substances was determined and thus the foundation laid for larger series of experiments in the coming year. ${ }^{550}$

It is no longer possible to reconstruct which substances were used in these series of experiments - possibly a conversation which Magnussen conducted with Adolf Butenandt on December 2, 1942 concerned the question as to which hormones should be applied in the animal experiments. ${ }^{551}$ It proceeds from an essay fragment - which presumably originated in 1948 - that Magnussen dropped adrenaline into the eyes of several chinchilla rabbits in experiments performed privately from 1946 to 1948 , as well as the extraneous substances physostigmine, atropine, and doryl. ${ }^{552}$

\footnotetext{
${ }^{548}$ Magnussen, Bericht über die Durchführung der Arbeiten zur Erforschung der Erbbedingtheit der Entwicklung der Augenfarbe als Grundlage für Rassen- und Abstammungsgutachten, 2/10/1944, ibid., p. 38.

${ }^{549}$ Magnussen, Bericht über die Durchführung der Arbeiten zur Erforschung der Erbbedingtheit der Entwicklung der Augenfarbe als Grundlage für Rassen- und Abstammungsgutachten, 24/9/1943, ibid., p. 69.

${ }^{550}$ Magnussen, Bericht über die Durchführung der Arbeiten zur Erforschung der Erbbedingtheit der Entwicklung der Augenfarbe als Grundlage für Rassen- und Abstammungsgutachten, 2/10/1944, ibid., p. 38 .

${ }^{551}$ Massin, Mengele, p. 242 (note 142); Klee, Medizin, p. 370.

${ }^{552}$ Hesse, Augen, p. 96.
} 
Fourth, Magnussen conducted series of experiments on the development of pigment in childhood at schools, combined with genealogical studies. Due to the war these serial studies rapidly became more difficult. In September 1943 Magnussen reported on this:

\begin{abstract}
In summer 1943 the studies about the pigment development in childhood and the required genetic inquiry among the families could be performed only on a smaller scale than previously, due to the drafting of fathers for military service and the evacuation of children. Yet the observations are still in progress and, as soon as the situation in the air permits, will be continued on a larger scale. [...] As the start of a larger series of observation series, serial examinations about iris structure and eye pigmentation were performed on over 1,300 children in Holstein. ${ }^{553}$
\end{abstract}

Half a year later she sounded less optimistic: "The remaining observations of humans had to be discontinued for a time for reasons concerned with the war, but are to be resumed in summer, to the extent possible." ${ }^{554}$ In addition to the serial examinations in Holstein (Eutin), two further were performed in Baden (Wolfach) and Upper Bavaria (Mittenwald), and moreover "in Eutin and Mittenwald family studies to investigate the heredity of certain structural attributes [...] (especially important for opinions on descent). ${ }^{555}$ Further studies of schoolchildren planned "in several cities of the Reich" 556 had to be discontinued in September 1944, since they were not categorized as of strategic importance, and because "by no means [were] they to interfere with lessons." 557

Magnussen's research report of October 1944 shows that, once the serial examinations of the German population had been disrupted, Magnussen intended to start a parallel study in the world of the National Socialist camps: "The first series of observations of alien nations in a prisoner of war camp, planned as a comparison with the German population, was prevented by enemy operations. Further series of

\footnotetext{
${ }^{553}$ Magnussen, Bericht über die Durchführung der Arbeiten zur Erforschung der Erbbedingtheit der Entwicklung der Augenfarbe als Grundlage für Rassen- und Abstammungsgutachten, 24/9/1943, BArch. Koblenz, R 73/15.342, p. 69.

${ }^{554}$ Magnussen, Bericht über die Durchführung der Arbeiten zur Erforschung der Erbbedingtheit der Entwicklung der Augenfarbe als Grundlage für Rassen- und Abstammungsgutachten, 13/3/1944, ibid., p. 68.

${ }^{555}$ Magnussen, Bericht über die Durchführung der Arbeiten zur Erforschung der Erbbedingtheit der Entwicklung der Augenfarbe als Grundlage für Rassen- und Abstammungsgutachten, 2/10/1944, ibid., p. 38. On this also, Verschuer to Fischer, 12/7/1943, MPG Archive, Dept. III, Rep. 86 A (Münster), No. 9: "Miss Magnussen was just here. She performed iris examinations of schoolchildren in Eutin (Schleswig-Holstein) and collected very interesting findings. It is necessary for her to examine populations in Germany of different racial composition in the same manner. Presumably she will best find the Alpine groups in the Black Forest. I am writing to my sister in Wolfach, which seems to me a suitable location. Do you perhaps have any other suggestions and connections to arrange Miss Magnussen's study? She could undertake the journey in either late August or October."

${ }^{556}$ Reichsministerium für Wissenschaft, Erziehung und Volksbildung to Reichsforschungsrat, 8/9/1944, BArch. Koblenz, R 73/15.342, p. 51.

${ }^{557}$ Graue to Reichsministerium für Wissenschaft, Erziehung und Volksbildung, 21/9/1944, ibid., p. 50.
} 
studies of this kind are planned for the coming months." 558 At the current state of knowledge we have no more details about this first serial study in a war prison camp, for which there were already concrete plans, but which never took place which camp was involved, who the prisoners were whose eyes were to be measured, in what manner and with whose help Magnussen intended to gain access to the camp. Neither do we know whether such studies ultimately did take place in other camps and, if so, what happened.

The fifth subarea of Magnussen's project was histological, in which she dissected the eyes of rabbits, and of humans as well, in series of microtome cuts. As proceeded from the progress report of September 1943, this area had high priority:

At the moment, primarily the histological works are being performed, so that the irreplaceable material is processed and thus not subjected to the risk of loss due to long storage. ${ }^{59}$

From this emerged a paper "About the Relationships between Iris Color, Histological Pigment Distribution and the Pigmentation of the Bulbus in the Human Eye," which was completed in 1944, but not published until 1949. ${ }^{560}$ For this study Magnussen used the eyes of " 31 subjects from central Europe" and compared them with "specimens from the institute's collection, of the dissected eyes of colored races and of a Papuan eye." ${ }^{561}$ Magnussen failed to make any mention of who those 31 people from central Europe were. Hans Hesse suspects that they could also have been concentration camp inmates. In procuring her material, Magnussen had few scruples: according to Benoît Massin's account, Magnussen also worked on the eyes of people who were murdered by the Gestapo and made available to the anatomist Hermann Stieve (1886-1952) in Berlin. ${ }^{52}$ By the way, it is equally unclear where the dissected specimens of "races of color" contained in the institute's collections came from, which Magnussen studied comparatively. ${ }^{563}$

Sixth and finally, Magnussen was interested in anomalies of the eye, such as corneal conjunctivalization, ${ }^{564}$ but above all heterochromia. In October 1944 she

\footnotetext{
${ }^{558}$ Magnussen, Bericht über die Durchführung der Arbeiten zur Erforschung der Erbbedingtheit der Entwicklung der Augenfarbe als Grundlage für Rassen- und Abstammungsgutachten, 2/10/1944, ibid., p. 39.

${ }^{559}$ Magnussen, Bericht über die Durchführung der Arbeiten zur Erforschung der Erbbedingtheit der Entwicklung der Augenfarbe als Grundlage für Rassen- und Abstammungsgutachten, ibid., p. 69.

${ }^{560}$ Magnussen, Beziehungen. Cf. also idem., Beitrag.

${ }^{561}$ Magnussen, Beziehung, p. 296.

${ }^{562}$ Massin, Mengele, p. 246.

${ }^{563}$ The "Papua eye" had been provided to Magnussen by Eugen Fischer.

${ }^{564}$ Magnussen had established corneal conjunctivization in several animals of one strain of rabbits from Nachtsheim's breeding experiments. At the same time, Georg Wagner, in his examinations of "Gypsy twins" apparently discovered in East Prussia two "clans" of "Gypsy half-breeds of predominantly Gypsy descent" in which this anomaly occurred with unusual frequency (Wagner, Partielle Irisfärbung, pp. 62,64). Thereupon Magnussen systematically investigated a series of human eyes provided by Hermann Stieve for the occurrence of this anomaly and found several cases. She also found "during the systematic investigation of the eye specimens of colored races at the institute [...] a corresponding tissue fold in a Negro." She concluded that the conjunctivization "is propagated more widely
} 
announced: "A paper about the histology of total heterochromia in humans is about to be concluded." ${ }^{655}$ This work had become possible through one of the most monstrous medical crimes by Josef Mengele in the Auschwitz concentration and extermination camp.

In 1942 "a member of the institute's staff who worked on criminal biology issues" 566 - from another source it is clear that this meant Georg Wagner -, in one of the "mixed-breed Gypsy clans" he had examined, ${ }^{567}$ which also included several pairs of twins, established an increased frequency of heterochromia, "in addition to other supplementary findings interesting in terms of genetic biology." ${ }^{668}$ It is highly probable, as Hans Hesse convincingly portrayed, that the family in question was that of the Sinto Otto Mechau of Oldenburg.

Verschuer commissioned Magnussen with the task of taking on the "genetic biological analysis" 569 of this case of heterochromia. To the institute director, this Sinti clan must have seemed a rare godsend in several respects at once: first, as mentioned above, heterochromia represented an extremely interesting anomaly within the phenogenetic concept, which promised information about the way gene action chains worked in phenogenesis. Second, in this case - as a consequence of the complete inventory of Sinti and Roma aspired to by the "Reich Central Office of Gypsies" and the "Race Hygiene Research Office" - it was possible to create a complete family table, clarify the genealogical relationships of the "clan" and thus

and occurs in various races" (Magnussen, Hornhautüberwachsung, p. 62). On these two papers, cf. also Verschuer to Fischer, 19/11/1943, MPG Archive, Dept. III, Rep. 86 A (Münster), No. 9.

${ }^{565}$ Magnussen, Bericht über die Durchführung der Arbeiten zur Erforschung der Erbbedingtheit der Entwicklung der Augenfarbe als Grundlage für Rassen- und Abstammungsgutachten, BArch. Koblenz, R 73/15.342, p. 38 f.

${ }^{566}$ Protokoll der Vernehmung Karin Magnussens durch die Spruchkammer Bremen am 25.5.1949, MPG Archive, Dept. I, Rep. 3, No. 26.

567 Ibid.

${ }^{568}$ Magnussen to Schwartz, 2/3/1949, quoted in Klee, Medizin, pp. 363. Cf. also Verschuer's assertion that Wagner had "left [him] 2 interesting twin cases from his material for utilization elsewhere." Verschuer to Fischer, 31/3/1943, MPG Archive, Dept. III, Rep. 86 A (Münster), No. 9.

${ }^{569}$ That she researched independently, but on Verschuer's orders, that she kept him constantly informed about the progress of her work and could not publish her research results without Verschuer's approval, Magnussen left no doubt in her defense testimony after the end of the war: "Special works at scientific institutes are in the hands of specialists, who perform this work alone. - The directors of the institute have knowledge of the execution of these projects, which are published under the name of the institute and the director, who must give his approval for publication. - The directors have a direct stake in the performance of the research only when they sign as authors themselves." Protokoll der Vernehmung Karin Magnussens durch die Spruchkammer Bremen am 25/5/1949, MPG Archive, Dept. I, Rep. 3, No. 26. A letter by Magnussen to Viktor Schwartz, an associate of Alfred Kühn, of March 2, 1949 includes the passage: "The genetic biological analysis of the matter was thus [because she had worked on the phenomenon of heterchromia "for years" already] conferred to me by Prof. von Verschuer." Quoted in Klee, Medizin, p. 363. In her written statement of November 22, 1966 she again wrote: "Since he [Wagner] had neither time nor interest in this problem himself, the institute director delegated the scientific analysis of this matter to me, for it fell to my area of specialization (time: winter semester 1942/43?)."Quoted in Hesse, Augen, p. 92. 
possibly obtain conclusions about the heredity of heterochromia. Third, because the Sinti and Roma were "locked up" in "Gypsy collection points," the test subjects were together at close quarters and - even more important - in the completely lawless area in which Sinti and Roma were now compelled to live, there were practically unlimited possibilities for access. The scientists could thus perform all examinations and collect all data they liked - even against the will of the affected. Fourth, the circumstance that this family included several pairs of twins with heterochromous eyes presented a truly unique opportunity to combine family and twin research in order to investigate the developmental physiological events in the emergence of heterochromia. For this, however, an imperative prerequisite was the histological examination of the heterochromous eyes of the twins - and that meant: the death of these children. Fifth, it must have seemed an advantage that the affected family was also the object of criminal biology research - as such, supposedly genetic physical stigmata like heterochromia or deaf-muteness potentially could be linked with supposedly genetic social deviance. Sixth, the circumstance that the family was classified in the group of "Gypsy half-breeds" built a bridge between phenogenetics and race research, and race diagnostics in particular. Thus it is no surprise that Verschuer strived to obtain additional financing from the German Research Association for this central research project.

Clear is that Magnussen performed eye examinations of members of the Mechau family before their deportation to Auschwitz in March 1943. ${ }^{570}$ After the war she gave contradictory accounts about the exact course of events. In her interrogation by the Bremen Denazification Commission on May 25, 1949 she testified: "In spring 1943 I took my own photographs of the eyes of such twins at the institute in Dahlem, before the twins ended up at Auschwitz." 571 A short time before, on March 2, 1949, in contrast, Magnussen had written in a letter to Viktor Schwartz, an associate of Alfred Kühn's:

The only thing I got to see of the entire clan was two young boys without an eye anomaly,
for all of the clans were interned around that time, namely in Auschwitz. Since civilians
were not admitted, any inspection of the people was made impossible during the period of
their prophylactical internment. I had a "criminal" twin researcher, who was allowed to
visit the camp in his capacity as a officer of medical corps, bring me back color photo-
graphs of a number of the people at the time, so that I had a small foundation, but it was
very imprecise." 572

The officer of the medical corps described here ironically as a " 'criminal' twin researcher" was, as mentioned above, Siegfried Liebau. ${ }^{573}$ A written statement by Magnussen of November 22, 1966, submitted in the course of the preliminary

\footnotetext{
${ }^{570}$ According to the Gedenkbuch. Die Sinti und Roma im Konzentrationslager AuschwitzBirkenau, München 1993, the Mechau family was admitted to the Auschwitz extermination camp on March 14, 1943. Cf. Hesse, Augen, p. 22.

${ }^{571}$ Protokoll der Vernehmung Karin Magnussens durch die Spruchkammer Bremen am 25/5/1949, MPG Archive, Dept. I, Rep. 3, No. 26.

${ }^{572}$ Quoted in Klee, Medizin, pp. $363 \mathrm{f}$.

${ }^{573}$ Liebau confirmed this himself in later testimony. Cf. Klee, Auschwitz, p. 483.
} 
proceedings of the Münster Public Prosecutor versus Otmar von Verschuer, states in contrast:

At the time I had seen only one pair of twins from this clan, which had come to the institute in Dahlem for the doctoral student [Wagner]. I was able to photograph the eyes of both children on this occasion. At the time it was said that these twins (like a major portion of this clan already) were supposed to be sent to an internment camp. At the time I was told that antisocial clans were to be interned in this camp for the duration of the war as a preventative measure. ${ }^{574}$

Thus, it is probable that Magnussen herself photographed the (homochromous) eyes of one pair of twins from the Mechau family, which Georg Wagner had brought to the institute in Dahlem for examination before their deportation to Auschwitz in March 1943, and that she received additional photographs of the (heterochromous) eyes of members of the family in Auschwitz from Liebau.

Through the deportation, Magnussen had lost direct access to the Mechau family, since she could not be admitted to the "Gypsy camp" in Block B II e of the concentration and extermination camp at Auschwitz-Birkenau. Initially Liebau continued to help her. Then, effective May 30, 1943, Josef Mengele was assigned to Auschwitz. Magnussen related how the collaboration with Mengele came about in her denazification testimony of 1949:

I met Dr. Mengele, who had been drafted as a Medical Corps officer, in Dahlem during the war, when he visited the institute while on leave. - I spoke with him a few times during such visits to the institute about scientific papers and scientific problems. [...] I performed my research tasks, despite the fact that any access to members of the heterochromia clan was barred after its internment in Auschwitz, and this was only possible with the help of Dr. Mengele, who was coincidentally detached to the camp as a physician. - At the time he made it possible for me to elucidate heredity by determining the eye colors and relationships between the members of the clan. - Through him I also learned that one of the most important families of the clan was contaminated with pulmonary tuberculosis. - Thereupon I requested that, if possible, he should send me the autopsy and the pathological eye material if anyone in this family died. ${ }^{575}$

At the same time, she expressed to Viktor Schwartz:

Had I not heard from Prof. von Verschuer that a previous associate of his [Mengele] had been ordered to the camp as a physician, I would have been able to base the further genetic biology of the attribute only upon police files. Through this colleague, who recorded the attributes precisely and compiled the family tables, I learned that a part of the clan was contaminated with pulmonary tuberculosis, above all a family with 12 children. ${ }^{576}$

In her written testimony from 1966 Magnussen went into this point in greater detail:

My demand to be able to visit the remaining members of the clan in the camp was rejected as impossible. At that time I was forced to conclude that women were strictly forbidden

\footnotetext{
${ }^{574}$ Quoted in Hesse, Augen, p. 92.

${ }^{575}$ Protokoll der Vernehmung Karin Magnussens durch die Spruchkammer Bremen am 25/5/1949, MPG Archive, Dept. I, Rep. 3, No. 26.

${ }^{576}$ Quoted in Klee, Medizin, p. 364.
} 
from setting foot in the camp. Prof. von Verschuer thus referred me to Dr. Mengele, who had been his assistant in Frankfurt, and who had been ordered to the camp as a physician (officer of the Medical Corps). I did not know Dr. M. at the time; I only knew from the literature that he worked in the field of genetics. During a visit to the institute in Dahlem (summer 1943?) I made his acquaintance and discussed with him the possibility of performing the research task. I asked him first of all to make sure that this clan not be lost track of after the war, so that the research on this very rare mutation could then be continued intensively. The work of the geneticist is entirely dependent on the life of the carriers of the gene, who hand their genes down to the next generation. At the time Dr. M. told me that a particularly important family was subject to tuberculous contamination (with 12 children). Everyone knew what that meant in those days, when there was still no remedy for pulmonary tuberculosis, especially for young people under 21 years of age. Thus I asked Dr. M., whenever any of the carriers of heterochromia should die, to send me protocols of the autopsy and the pathological eye material for examination if possible, - just as I would have in any other case. ${ }^{577}$

Magnussen's account cannot be confirmed, supplemented, or contradicted by other sources. As far as the framework of facts is concerned, it appears to be coherent and fits in logically with the reconstruction of the project on heterochromia: By this account Magnussen, when the project slowed down as a consequence of the deportation of the Mechau family, was alerted to Mengele by Verschuer. Had Mengele made efforts of his own to be ordered to Auschwitz, and had Verschuer known of these or even actively encouraged Mengele's assignment to Auschwitz, the tip to Magnussen might have been issued before the posting was ordered on May 24, 1943; on the other hand, had Verschuer been surprised by Mengele's transfer he might have informed Magnussen immediately after the command was issued. In either case it is conceivable that Magnussen, even before Menegele's departure from Berlin to Auschwitz, reached an agreement with him that he would compile the "family table" of the Mechau family on location in the "Gypsy camp" and presumably using the eye-color table developed by Magnussen - determine the eye color of the family members. Otherwise such a deal must have been made during one of Mengele's visits to Dahlem on leave. At this or a further meeting then, the arrangement must have been made concerning the family members supposedly suffering from pulmonary tuberculosis.

With some degree of certainty it can be presumed that Magnussen rendered the events by and large correctly in her postwar testimony. Her interpretation of what happened, however, can be scrutinized with a critical view to the sources. In her defense after World War II she made every effort to portray her arrangement with Mengele as entirely normal cooperation among colleagues. In 1949, she stated on record to the Bremen Denazification Commission:

I would have directed the same request as a matter of course to the hospital, the treating physician or the responsible pathologist, had I learned of a critical illness of a noninterned person from this clan. Naturally, I could not dispense with the evaluation of such valuable pathological material, which I would have obtained in any case under the circumstances.

\footnotetext{
${ }^{577}$ Quoted in Hesse, Augen, pp. $92 \mathrm{f}$.
} 
In her letter to Schwartz, Magnussen vested this argument in the form of a rhetorical question:

In cases of death should I thus dispense with the histological analysis of the unique, abnormal material just because the people happened to die in the camp? Otherwise I could have arranged to get the material from the responsible pathological institute. ${ }^{578}$

In her statement from 1966 she added that in 1942 she had also received from the Charité Hospital the heterochromous eyes of a deceased patient. ${ }^{579}$ The linchpin of this argumentation is Magnussen's assertion that she did not know that Auschwitz was an extermination camp. In her testimony to the Denazification Commission she claimed to have been unsuspecting:

According to the impression I had of the case histories and of the extremely responsible and humanly decent attitude of Dr. Mengele toward his interned patients and staff (after the war, he hoped to win over for the institute a certain female Polish physician interned in Auschwitz, as he told me), the idea would never have entered my mind that anything could occur at the Auschwitz camp that might violate state, medical or human laws. ${ }^{580}$

To Schwartz, too, Magnussen asserted that "nothing awful [was] known" to her; "on the contrary - from the case histories, the colleague's stories and from his human attitude to the inmates I could only have the impression of proper and decent treatment." ${ }^{581}$ Nevertheless, it seems more than improbable that Karin Magnussen, a scientist at an institute whose leading members had been involved in the discussions about the Generalplan Ost and who made no secret of their attitude toward the "Final Solution" of the "Jewish question" and the "Gypsy question," and, moreover, an active National Socialist with close contacts to the Race Policy Office of the NSDAP, had no knowledge at all of the genocide of Jews, Sinti and Roma and no conception at all of the conditions in a concentration camp; accordingly, this must be dismissed as nothing more than an attempt to rationalize her behavior. Rather, it can be assumed that it was altogether clear to Magnussen that the Sinti and Roma had hardly a chance of survival in Birkenau, and that this came in handy due to her interest in the eye specimens. ${ }^{582}$ Mengele's indication that a family was "contaminated" by tuberculosis could even be interpreted as a discreet offer to assist in their demise, and Magnussen's request to send her the specimens as consent.

\footnotetext{
${ }^{578}$ Quoted in Klee, Medizin, p. 364.

${ }^{579}$ Hesse, Augen, p. 93.

${ }^{580}$ Protokoll der Vernehmung Karin Magnussens durch die Spruchkammer Bremen am 25/5/1949, MPG Archive, Dept. I, Rep. 3, No. 26. At this juncture Magnussen also claimed that she did not know that other categories of prisoners besides "Gypsies" and "mixed-race Gypsies" were held at Auschwitz.

${ }^{581}$ Quoted in Klee, Medizin, p. 365. Magnussen went so far as to assert that even former prisoners from Auschwitz had "nothing awful" to report.

${ }^{582}$ The following testimony in her defense from 1949 must be relativized in this respect: "My work about the genetic biology of heterochromia was not performed on this clan because it was in a concentration camp, but rather even though it was interned in a camp, which made my work extraordinarily difficult, and almost impossible, had not a scientist coincidentally been assigned as a physican there. (Protokoll der Vernehmung Karin Magnussens durch die Spruchkammer Bremen am 25/5/1949, MPG Archive, Dept. I, Rep. 3, No. 26, original emphases).
} 
Magnussen herself admitted that such deliveries took place. In her Denazification Commission testimony of 1949 she stated:

Of the twelve children from the one family, initially two died in the years 1943 and 1944 (one of erysipelas and one of a pulmonary TB on both sides). A child from a related family died of pulmonary TB as well. The case histories and autopsy reports I received were painstakingly recorded..$^{53}$

At this juncture the testimony of two surviving prison physicians can be drawn upon for further information. In his memoirs, Miklós Nyiszli reports that on several occasions he was required to dissect the corpses of "Gypsy twins." Once the corpses were of four pairs of twins, that is, eight children who were under 10 years of age. Nyiszli established the cause of death to be injection of chloroform to the heart - therefore the children were murdered systematically. Nyizli related the further events as follows:

Of the four pairs of twins, three have eyes of different colors. One is blue, the other brown [...]. I dissect the eyes out and lay them, each separately, in formalin, whereby I note precisely all information about them, so that they cannot be mixed up. [...] In two pairs I also find an active pulmonary tuberculosis. [...] In the afternoon Dr. Mengele makes his rounds of the ward. [...] He is very interested in the heterochromia of the eyes [...]. Right away he instructs me to prepare the entire material for dispatch, along with the protocols, but I should also list the causes of death. He leaves it up to me what I write, but the causes of death must be different. Almost by way of apology he says that these children, as I could see myself, suffered from syphilis or tuberculosis and would not have been able to survive anyway, so ... He does not say anything more. ${ }^{584}$

This account is confirmed in its entirety by testimony from the SS commander Erich Mussfeld. ${ }^{585}$ Whether the children's corpses autopsied by Nyizli were members of the Mechau family must remain an open question. The children of the Mechau family may also have been autopsied by the Jewish Romanian prison physician Iancu Vexler, who worked in the "Gypsy family camp" from June 2, 1943. At least, this is what Hermann Langbein, himself a prisoner at Auschwitz reports:

\footnotetext{
${ }^{583}$ Ibid. Magnussen continued: "Before Prof. von Verschuer was relocated (early February 1945) I gave them [case histories and autopsy reports] back to his head nurse [Emmi Nierhaus], after I had completed the analysis of the histological material." By contrast, Magnussen wrote in her written testimony of 1966: "Extensive case histories and dissection protocols were sent to Dahlem with the eye specimens for inspection. After processing they had to be returned, as case histories are the property of the hospital or the treating physician as a matter of principle." Quoted in Hesse, Augen, p. 93.

${ }^{584}$ Nyiszli, Jenseits, pp. 46f. (original omission). The original Hungarian edition appeared in 1946 - that makes this report so valuable, for it was created before Magnussen's and Verschuer's defense testimony. - If Nyiszli (pp. 44-46) gave the "Race Biology and Anthropological Institute in Berlin-Dahlem" as the address for dispatch, this could - if it is not simply a mistaken memory - have been because one of the possible addressees, Wolfgang Abel, was both Director of the Department for Race Science at the KWI-A and, since 1943, Director of the Institute for Race Biology at the University of Berlin. Abel used letterhead with the address: "Institut für Rassenbiologie der Universität Berlin, Direktor: Professor Dr. W. Abel, z. Zt. Bln.-Dahlem, Ihnestr. 22 (Kais. Wilh. Inst. f. Anthropologie).” Cf. Sachse/Massin, Forschung, p. 24, note 49.

${ }^{585}$ Reprinted in: Hesse, Augen, p. 21.
} 
Vexler also reports about Mengele's laboratory in the sauna block of B II e, in which anthropological examinations took place, especially on hair and eye color. [...] Once a Gypsy family by the name of Mechau with striking heterochromia of the eyes was brought in. Mengele drew Vexler's attention to the family and ordered him: 'Well, good, when it's time - when that happens, understand? - you will carefully take out the eyes and put them in bottles prepared for you. They will go to Berlin for the investigation of the iris pigment. You understand, genetic issue, heredity dominant, recessive, etc. highly interesting. ${ }^{586}$

The parallel account suggests that several prison physicians were occupied with the autopsies of (twin) children with heterochromous eyes from the "Gypsy family camp" at Auschwitz-Birkenau - and there are additional indications that point in this direction. ${ }^{587}$ In any case the reports from the prison physicians confirm the suspicion that Mengele killed many more twin children from the "Gypsy family camp" because of their eyes, and delivered many more eyes to the KWI-A than Magnussen testified in her defense after World War II - in 1949 she spoke of three, in 1966 of five pairs of eyes that she received from Mengele. ${ }^{588}$ Nyiszli's report further suggests that several heterochromous pairs of eyes from twins ended up in Dahlem simultaneously. By this time at the latest it must have been clear to Magnussen that the children had to have died a violent death. Benoît Massin is justified to establish:

The case of the three heterochromous pairs of eyes from twins, which died more or less on the same day, must have been conspicuous and surprising. The very case that two twin siblings die "a natural death" on the same day and in the same place is a statistical rarity. Moreover, twins with heterochromous eyes are extremely seldom. But the death of six twin children with heterochromous eyes on the very same day or in the very same week is well outside the bounds of statistical probability and clearly points to a crime. ${ }^{589}$

The above-mentioned publication of her research results about the "Heredity and Histology of a Total Heterochromia of the Iris in Humans" failed in late 1944/early 1945, because from the article it was clear - at least, according to testimony by Georg Melcher (1906-1997) of the KWI for Biology and coeditor of the Zeitschrift für induktive Abstammungs- und Vererbungslehre at the time, in an interview with Benno Müller-Hill in the early 1980s - that all subjects died at the same time and thus it stood to reason to suspect that they had fallen victim to a crime. ${ }^{590}$ In 1953 Karin Magnussen herself claimed that her essay did not appear because the printing plates, ready to go to press at the time, were destroyed in an air raid ${ }^{591}$ - this was probably much closer to the truth. Then, after World War II, Magnussen's persistent attempts to place the manuscript after all - perhaps in the Zeitschrift für

\footnotetext{
${ }^{586}$ Quoted in Münzel/Streck (eds.), Kumpania, p. 123 (note 13). Cf. also Massin, Mengele, p. 240.

${ }^{587}$ According to Ernst Klee, the mother of the Hungarian composer György Ligeti also performed such autopsies. Klee, Medizin, p. 360.

${ }^{588}$ Benoit Massin must be confirmed (Mengele, p. 243), in that Magnussen, in view of possible fluctuations in manifestation, had to have been interested in the non-heterochromous eyes of the members of the Mechau family murdered at Auschwitz as well.

${ }^{589}$ Ibid., pp. $244 \mathrm{f}$.

${ }^{590}$ Müller-Hill, Tödliche Wissenschaft, p. 164.

${ }^{591}$ Magnussen to Fischer, 17/5/1952, reprinted in part in Klee, Medizin, p. 367.
} 
Morphologie und Anthropology, which was then edited by Hans Weinert - failed due to misgivings about the origin of the material investigated.

In Auschwitz, Mengele also performed experiments "about the possibility of a change in iris color," by dropping substances into the eyes of numerous children. The consequences of these experiments ranged from slight itchiness to swelling, inflammations, and suppurations of the eyes, in some cases the subjects lost their eyesight. Mengele even performed such experiments on newborn infants - with fatal results. According to the prison physician Ella Lingens (1908-2002), in 1944 a newborn died after Mengele injected a substance into its eye "because he was attempting to induce a change in eye color. Little Dagmar was to get blue eyes." ${ }^{\circ 92}$ In 1944 Irmgard Ludwig had her newborn child taken away from her. When she saw it again, the eyes looked "like a crude clump." It is not known what substance Mengele dropped into the children's eyes. According to a report by the Polish prison physician Rudolf Diem, Mengele claimed that the drops he had administered to persons with heterochromous eyes contained adrenaline: "He believed that the application of these drops would cause the iris color to change." 593

What at first glance seems to be a mad, pseudoscientific experiment to instantly "Aryanize" brown-eyed "Gypsy children" by injecting substances like methylene blue ${ }^{594}$ takes on a new meaning against the background of Magnussen's project on heterochromia. These experiments investigated the pigmentation of the human eye under phenogenetic aspects. Mengele did not perform these experiments "singlehandedly [...], but rather in 'teamwork' with Magnussen. Mengele was thus more than a passive supplier of dead 'human material,' and by no means did Magnussen research on dead objects only; she was actively involved in Mengele's human experiments." ${ }^{\prime 59}$ After the war Magnussen confirmed that she had taken part in Mengele's eye experiments, whereby she boldly redefined heterochromia as a disease and passed off the human experiments performed by Mengele in coordination with her project as an attempt to cure the subjects:

The histological investigation succeeded in obtaining an indication of the presumptive cause of the disturbing anomaly. - We decided to apply the results immediately in the interest of the same family as an attempt to cure the anomaly in one of the children. - Since animal experiments of this kind had already been performed with success by other scientists, and since we had received previous assurance from the University Ophthamological Clinic in Berlin that no unpleasant side effects of any kind were to be expected from the treatment planned (adding drops of a bodily substance for the purpose of restoring a disturbed function), the treatment was started. - Since the child, unfortunately, died after a few months, it was not possible to perform the treatment for a sufficient length of time to yield an externally visible success. - Shortly thereafter I received the eyes of this child for histological analysis, along with the eyes of another deceased child from this family contaminated with $\mathrm{TB},-$ (i.e., 4 of 12 children) and performed the histological analysis of these eyes as well, although the histological work on the first three pairs of eyes had been

\footnotetext{
${ }^{592}$ Langbein, Menschen in Auschwitz, p. 383.

${ }^{593}$ Quoted in Hesse, Augen, p. 78.

${ }^{594}$ For instance, Lifton, Ärzte, p. 423. In opposition: Massin, Mengele, p. 247.

${ }^{595}$ Ibid.
} 
concluded long ago. - The possibility that an advantageous effect of the treatment is present after two months is given in the histological examination, so that I would advise this treatment even today in a case with similar conditions. ${ }^{596}$

\subsubsection{Verschuer's "Specific Proteins" Project: The Attempt to Develop a Serological Race Test}

Also closely linked with the Auschwitz concentration and extermination camp was that secretive research project of Verschuer's, funded by the DFG and listed in the files of the Reich Research Council as "Experimental Research on the Determination of the Heredity of Specific Proteins as the Foundation of Genetic and Race Research.' 597 This project was long regarded as a contribution to genetic pathology research under the aspects of race and implicated with Diehl's tuberculosis research in the external office of the KWI-A in Beetz. One of the connections existed on the organizational level, for Verschuer's project used rabbits from Diehl's breeding; their sensitivization with human blood sera took place in the KWI-A "reception center" in Haus am See in Beetz, that is, in the direct vicinity of the External Department for Tuberculosis Research, and technical problems were resolved in part thanks to the know-how of the KWI for Biochemistry, which also provided consulting for genetic tuberculosis research. Yet there was also a connection on the conceptual level, to the extent that both projects fit in to the paradigm of phenogenetics. There may have been a practical connection beyond this, as it cannot be excluded that blood samples of sick patients were also targeted for use in the "Specific Proteins" project - more on this later. In this case there would have been the prospect of genetic pathology findings becoming available as a kind of "byproduct" of the "Specific Proteins" project.

However, it must be emphasized that the two projects did not constitute a single unit and that it is by no means correct to conceive of the tuberculosis project as a preliminary phase of the "Specific Proteins" project. Benno Müller-Hill and many others after him advanced the theory that the "Specific Proteins" project concerned the investigation of race-specific susceptibility or resistance to tuberculosis, and this, in turn, was connected with the theory that Josef Mengele had purposely infected inmates of the Auschwitz camp with tuberculosis on behalf of the KWI-A. ${ }^{598}$ In contrast to this, Bernd Gausemeier formulated the theory that the project pursued the goal of developing a serological

\footnotetext{
${ }^{596}$ Protokoll der Vernehmung Karin Magnussens durch die Spruchkammer Bremen am 25/5/1949, MPG Archive, Dept. I, Rep. 3, No. 26. The written testimony by Magnussen of 1966 reads: "After discussion with Dr. M. (1944), next a medical treatment was performed on a child-age member of the clan. According to previous consultation with an ophthamological clinic, there were no side effects of any kind to be feared from the drop-by-drop addition of a bodily substance. [...] After the death of the patient some time later there was a histological finding that could be interpreted as the first successful cure, but which bears no conclusiveness." Quoted in Hesse, Augen, p. 93.

${ }^{597}$ Thus the datum in the file of the Reich Research Council. BArch Berlin, R 26 III/6, p. 82.

${ }^{598}$ For the first time in: Müller-Hill, Tödliche Wissenschaft, pp. 71-75. Most recently in: idem., Blut, esp. pp. 204-212.
} 
race test. ${ }^{599}$ Achim Trunk recently subjected both positions to meticulous critique, reaching the conclusion that Gausemeier's theory can be reconciled with the scant source material available much better than that of Müller-Hill. ${ }^{600}$ I concur with Gausemeier's position, whereby I can submit a document not yet taken into consideration that provides magnificent confirmation for Trunk's analysis.

The "Specific Proteins" project was presumably launched in spring 1943. It was acknowledged as strategically important and thus received special funding as regarded material procurement, but yet - in contrast to the tuberculosis project - it was rated as the lowest priority $S$. The first indications as to what the project was about appeared in Verschuer's interim report to the DFG of September/October 1943:

\begin{abstract}
Once all materials for the performance of this research had finally been delivered, the first preliminary examinations were begun and the methods tried out in consultation with Privy Councilor Abderhalden, Halle. An interruption in the work occurred when this branch of research was moved to the reception center of the institute in Beetz, but by now the laboratory there is completely equipped. Work can be continued. ${ }^{601}$
\end{abstract}

Two things can be taken from this report: The project had been temporarily moved to Haus am See in Beetz, and it used a method that was widespread in Germany at the time, although controversial, "Aberhalden's reaction." ${ }^{602}$ This procedure, developed by the Swiss biochemist Emil Abderhalden starting in 1909, proceeded from the basic assumption that an animal organism can recognize and destroy a foreign protein that penetrates it - such as those of bacteria in the case of an infection - by manufacturing enzymes (at that time they were known as "ferments") that catalyze a defensive reaction against the foreign protein. The "protective ferments," the presence of which Abderhalden and his pupils believed they could demonstrate in blood, and since 1930 in urine, ultimately turned out to be chimerical. The entire edifice of teachings constructed by Abderhalden was founded on either fraud and/ or - scholars are still arguing about this - on error and self-deception. In the early 1940s Abderhalden had faced increasing criticism, but his method had not yet been clearly disproved. Broad hopes were still linked with the method; it was believed that it might open up new possibilities for the diagnosis of infectious diseases, cancer, and even psychoses. What is more: in the second half of the 1930s, Abderhalden and his pupils attempted to use protective ferments for the determination of race in sheep and pigs. "This important research," Verschuer commented in his review, "finds the greatest interest of the genetic biologist [...]." ${ }^{\prime 63}$ In 1940 Abderhalden

\footnotetext{
${ }^{599}$ Gausemeier, Radikalisierung.

${ }^{600}$ Trunk, Zweihundert Blutproben (edited and abridged version: idem., Rassenforschung).

${ }^{601}$ Verschuer, Bericht über das Projekt "Spezifische Eiweißkörper" an die DFG, n.d. [September/ October 1943], BArch. Koblenz, R 73/15.342, p. 55. On September 20, 1943 Verschuer reports to Fischer that he now had the technical assistent Irmgard Eisenlohr and that "with her the research with Abderhalden's reaction, now finally picking up steam," was moved to Beetz. Verschuer to Fischer, 20/9/1943, MPG Archive, Dept. III, Rep. 86 A (Münster), No. 9.

${ }^{602}$ Müller-Hill/Deichmann, Fraud; Deichmann, Flüchten; Kaasch, Sensation; Lindemann, Abderhaldens Abwehrenzyme.

${ }^{603}$ Verschuer, Review Emil Abderhalden, Rasse und Vererbung, pp. $91 \mathrm{f}$.
} 
and Verschuer exchanged several letters, in which it was Abderhalden's idea to investigate the reactions of protective ferments in twins. Verschuer rejected this for the time being, referring to the difficulties of obtaining blood samples. ${ }^{604}$

The correspondence between Verschuer and Abderhalden shows that in 1943 the latter was training one of Verschuer's medical-technical assistants to use his methods in Halle - Müller-Hill's investigations produced evidence that the assistant in question was Irmgard Eisenlohr (from 1944: married Haase). ${ }^{605}$ The second interim report by Verschuer to the DFG of March 1944 confirms clearly that Abderhalden's method was applied in the "Specific Proteins" project:

In the trials of the methods new difficulties have come to light, which were resolved in consultation with Privy Councilor Abderhalden, Halle. Series of rabbits are being subjected to thorough testing in order to find animals free of spontaneous ferments and thus suitable for the experiments. My assistant Dr. med. et Dr. phil. Mengele has come in as an associate in this branch of research. He is stationed in the Auschwitz concentration camp as Hauptsturmführer and camp physician. With permission of the Reichsführer SS, anthropological examinations are being performed on this camp's many different racial groups and the blood samples sent to my laboratory for analysis. ${ }^{606}$

This is the first evidence that the "Specific Protein" project used blood samples from people of different races, which came from Josef Mengele. In two letters by Verschuer to the pediatrician Bernhard de Rudder, a close friend of his and Diehl's, he goes into greater detail about the blood samples supplied by Mengele. In October 1944 Verschuer wrote:

Plasma substrates were produced from over 200 people of various races, pairs of twins and a number of families. ${ }^{607}$

\section{And a letter of January 1945 reads:}

I have the substrates from the blood sera of over 200 persons of various racial descent and also of pairs of twins and a few families ready, so that it is now possible to start the actual comparative studies. ${ }^{608}$

\footnotetext{
${ }^{604}$ Kaasch, Sensation, pp. $183 \mathrm{f}$.

${ }^{605}$ Ibid., p. 186. Müller-Hill, Tödliche Wissenschaft, pp. 162 f.

${ }^{606}$ Verschuer, Bericht über das Projekt "Spezifische Eiweißkörper" [for the period from October 1, 1943 to March 31, 1944], March 20, 1944, BArch. Koblenz, R 73/15.342, p. 64.

${ }^{607}$ Verschuer to de Rudder, 4/10/1944, MPG Archive, Dept. III, Rep. 86 A (Münster), No. 8.

${ }^{608}$ Verschuer to de Rudder, 6/1/1945, ibid. In a position paper of 1946 Verschuer claimed that he received these blood samples from various sources: "To perform Abderhalden's protective ferment reaction in order to study the individual specificity of the serum proteins, I received blood samples sent from several hospitals, like those taken for most clinical investigations (Wassermann's reaction, the erythrocyte sedimentation rate [ESR]), around $5-10 \mathrm{ccm}$, without harming the health of the patient in any way. Among these were also blood samples from the sick bay where that assistant from Frankfurt worked in Auschwitz [i.e. Mengele]. In this manner I received - over the course of time, not at regular intervals - several dispatches of 20-30 blood samples each, also amounting to around 5-10 ccm each." Verschuer, Stellungnahme zu den Angaben, die sich auf meine Person beziehen und in der "Neuen Zeitung" Nr. 35 vom 3/5/1946 unter der Rubrik "Kunst und Kultur in Kürze" in der Notiz "Vertriebene Wissenschaft" erschienen sind, Universitätsarchiv Frankfurt/Main, Dept. 13, No. 347, p. 179.
} 
What these "actual comparative studies" involved and what purpose they pursued is a matter of great controversy in historical research. Achim Trunk reconstructed the course of events as follows: From the blood samples serum was extracted and sent to Berlin. From this, dry preparations were produced in the laboratory, which were then supposed to serve as the "substrate" converted by the protective ferment in the defense reaction. Meanwhile, the search was on for suitable test rabbits, i.e. ones that did not already have the capability to decompose the foreign protein before they were inoculated with this protein. This is what Verschuer was referring to with his comment that "series of rabbits [had been] subjected to thorough testing in order to find animals free of spontaneous ferments." When suitable rabbits were found, researchers injected them subcutaneously with a portion of the dried substrate and waited until they developed protective ferments against the race-specific human proteins. In the next step the protective ferments supposedly created had to be isolated. To do this, the urine of the rabbits was collected in special apparatus, as it was believed that the protective ferments were excreted with the urine. All substrates were then subjected to cross-reactions by adding the ferment solutions extracted from the rabbit urine in order to determine similarities and differences between the substrates. The final objective was to identify a panoply of protective ferments, each of which reacted with the proteins from the blood of a very specific human race. This would indeed have opened the way for a biochemical race test that would have eclipsed all anthropometric methods of race diagnostics attempted up to that time.

A letter from Verschuer to Karl Diehl of July 17, 1944 presents impressive confirmation for Trunk's version of events:

The experiment about the serum proteins with Abderhalden's reaction has proceeded to the
point where I have copious material at hand in the form of substrates. A conversation I
conducted a few days ago with one of Butenandt's assistants gives me occasion to begin
now with the actual experiment, i.e. the reaction with the protective ferments generated in
the rabbit. To do this, first of all, as last fall, the rabbits must be subjected again to thor-
ough tests for the presence of spontaneous ferments, so that we can finally arrive at an ani-
mal that tests negative for ferment. Therefore I request of you, just as you did last fall, to
allow that a few animals from each of your normal breeds be placed into the special cages
so that urine can be collected for the examination. ${ }^{609}$

This clearly proves that which Trunk held to be very probable: the "Specific Proteins" project quite clearly did not concern protective ferments against tuberculosis or any other infectious disease in the blood samples taken by Mengele in Auschwitz. Rather, these served without a doubt as substrates, which were to be converted by protective ferments extracted from rabbits.

Also worthy of emphasis in this letter by Verschuer is the term normal breeds. What must be kept in mind here is that Diehl held not only rabbits from the two pure breeds in his stalls - the ones he called "lung and belly rabbits" - and from the cross of these two breeding lines, but beyond these also a great number of other

${ }^{609}$ Verschuer to Diehl, 17/7/1944, MPG Archive, Dept. III, Rep. 86 A (Münster), No. 7 (my emphasis, HWS). 
rabbits, of which many gave their lives for "preliminary experiments," for instance, by using glycerine to extract from their lungs a culture medium for tuberculosis bacilla. ${ }^{610}$ The normal breeds were very valuable for Diehl - in December 1942 he answered the Verschuer family's inquiry as to whether he could spare a rabbit or two for the Christmas feast in the negative. ${ }^{611}$ Presumably with a heavy heart, he declared himself willing to make rabbits from the "normal breeds" available for the "Specific Proteins" project, in return for Verschuer's submitting a DFG application to obtain funding for his "Tuberculosis" project.

The point here is that the "Specific Proteins" project had nothing to do with Diehl's pure breeds and the crosses between these pure breeds. Thus, we can exclude with a high degree of probability that the human tuberculosis bacilla, with which a portion of the pure breeds were pretreated according to Verschuer's statement, came from Auschwitz.

In Verschuer's letter to Diehl of July 17, 1944 the "Specific Proteins" project's connection with the KWI for Biochemistry becomes clear for the first time. The report by Verschuer to the DFG of October 1944 provides further explanation:

The research has continued to enjoy intensive support. Blood samples of over 200 persons of various racial descent were processed and substrates of the blood plasma produced. The further research will be continued in collaboration with Dr. Hillmann [Günther Hillmann (1919-1976)], a staff member of the Kaiser Wilhelm Institute for Biochemistry. Dr. Hillmann is a biochemical specialist for protein research. With his help Abderhalden's original method has been perfected, so that now the actual experiments on the rabbits finally can be started. ${ }^{612}$

Much has been written about Hillmann's involvement, his position at the KWI for Biochemistry, his relationship to Butenandt and the responsibility of the latter for Hillmann's commitment to the "Specific Proteins" project. ${ }^{613}$ Here just this much: from November 1944 to February 1945 Irmgard Haase, advised by Hillmann, continued working on the project. When it had to be disrupted due to the war, she had "just sensitivized the first rabbits with the dried sera." ${ }^{14}$ As late as February 1945, Verschuer addressed Butenandt from his family estate in Solz, Hesse, to which a large portion of the KWI-A had been relocated by then, "because of his problem child, protein research," ${ }^{15}$ inquiring about possibilities to continue his research ultimately in vain. In the end, Butenandt wrote to Verschuer on October 18, 1945:

\footnotetext{
${ }^{610}$ Diehl to Fischer, 10/8/1942, ibid. At this point in time Diehl had around 450 live rabbits at his disposal, although around 100 young animals had died in the previous weeks.

${ }^{611}$ Diehl to Verschuer, 20/12/1942, ibid.

${ }^{612}$ Verschuer, Bericht über das Projekt "Spezifische Eiweißkörper" [for the period from April 1 to September 30, 1944], 4/10/1944, BArch. Koblenz, R 73/15.342, p. 47.

${ }^{613} \mathrm{Cf}$. Trunk, Zweihundert Blutproben, pp. 16-23, 50-53, 67-73, and Schieder/Trunk (eds.), Adolf Butenandt. On the friendship between Verschuer and Butenandt cf. also Sachse, Adolf Butenandt.

${ }^{614}$ Müller-Hill, Tödliche Wissenschaft, p. 163.

${ }^{615}$ Verschuer to Butenandt, 28/2/1945, MPG Archive, Dept. III, Rep. 84/2, general correspondence.
} 
"It is too bad that our shared work plans cannot be continued at the time being, but I hope it will be possible later." 616

From what was said it should have become obvious that while the "Tuberculosis" and "Specific Proteins" projects were closely linked together on the practical level, they pursued different objectives and were located in different fields of research: Diehl's tuberculosis research fit into the long series of genetic pathology projects at the KWI-A, while the "Specific Proteins" project concerned human races. Nevertheless Verschuer, as proceeds clearly from his letters to de Rudder, saw a close connection between the two projects. This is evinced particularly by a letter of October 4, 1944, in which Verschuer named the two projects in one breath with regard to his impending lecture to the academy:

Diehl obtained new, and as I believe, fundamentally very important research in his tuberculosis research. [...] I believe that my research about the question as to the heritability of specific proteins is also connected to the problem as a whole. [...] The goal of my different endeavors is now not only to establish that the influence of heredity is important in some infectious diseases, but in what manner it takes action and what kind of processes occur in these cases. ${ }^{617}$

At first glance this passage appears to speak for Müller-Hill's reconstruction of events, according to which the "Specific Proteins" project did have the object of race-specific dispositions or resistances to tuberculosis. It is clear that Verschuer was interested in such issues. In his lecture to the academy on November 16, 1944 he hit on the gradual differences in the susceptibility and frailty of various human races with regard to infectious diseases - here he also mentioned the supposedly greater resistance of Jews to tuberculosis - but he added, with reference to a publication by de Rudder, that it had yet to be elucidated "whether these differences are truly conditioned by the different genetic disposition of the races and not by other influences." ${ }^{18}$ The "Specific Proteins" project actually promised to contribute to the clarification of this question indirectly, and thus there was an internal connection to tuberculosis research. The conceptual brackets around the two projects were constituted by the paradigm of phenogenetics. While each of the projects had a practical application in mind: Diehl's attempt to breed rabbits resistant to tuberculosis was borne by the hope of discovering a biochemical substance that could also give humans protection from tuberculosis - and this without inoculation. At the forefront of Verschuer's protein project was the development of a biochemical race test. However, it must not be overlooked that both projects were apparently understood as complementary contributions to theoretical research in the area of phenogenetics, as they both aimed at the level of the proteome, where the gene action chains proceeding from the genome are set into action and shape the phenome, where race attributes are developed and many of the dispositions for diseases were also established.

\footnotetext{
${ }^{616}$ Butenandt to Verschuer, 18/10/1945, MPG Archive, Dept. III, Rep. 84/1, No. 601.

${ }^{617}$ Verschuer to de Rudder, MPG Archive, Dept. III, Rep. 86 A (Münster), No. 8.

${ }^{618}$ Verschuer, Wirkung von Genen, p. 383.
} 
The "Specific Proteins" project shows - as did Karin Magnussen's project on heterochromia, by the way - that research guided by the paradigm of phenogenetics, although it left behind the genetic determinism of the old race hygiene and race anthropology, was by no means invulnerable to drifting into the zone of crime. My theory is that one can conclude from this that in the area of the science of humans there can be no security against crossing scientific boundaries inherent in the paradigm guiding research - whatever shape it may take - . Every form of research on humans takes place in the tug of war between the researcher's interest in scientific knowledge and the human and civil rights of the person researched, regardless of their idea of man, that is, no matter whether they regard the individual as a pure product of his or her genetic information, as result of the interplay between heredity and environment, or as a tabula rasa that is marked by the environment. Drawing science-ethics boundaries takes its basis of legitimation from values held beyond the sphere of science.

\subsubsection{Model and Competition: Karl Horneck and his Research Project About "The Serological Race Differentiation of Humans"}

Otmar von Verschuer was neither the only one nor the first to work on a serological race test. The anthropologist Theodor James Mollison had long been concerned with the question as to whether serological race diagnostics was possible. Mollison attempted to reach his goal using the "precipitine reaction." This reaction involved the formation of precipitation that occurred when blood serum from another animal, for example, from a chimpanzee, was injected into a rabbit, and the antiserum, which was produced from the blood of a rabbit immunized in this fashion, was mixed with the original serum of the chimpanzee. If the same antiserum was allowed to react with sera of related species - like macaques, gibbons, orangutans, or humans - the precipitin reaction varied in strength. Mollison traced this back to proteins in the blood serum specific to each species. What was true for animal species, Mollison deduced, must also be applicable to human races. Therefore, since the 1920s he had been attempting to develop serological race diagnostics on the basis of the precipitin reaction. ${ }^{619}$

Other scientists in the Third Reich picked up on this approach. Werner Fischer (1895-1945) $)^{620}$ from the Scientific Department of the Institute for Experimental Cancer Research in Heidelberg under Ernst Rodenwaldt, who collaborated with Benno Raquet in 1938 to submit a paper "On the Question of the Proof of a

\footnotetext{
${ }^{619} \mathrm{Cf}$. Trunk, Zweihundert Blutproben, p. 10. On Mollison also: Kröner, Von der Rassenhygiene zur Humangenetik, p. 3. From Mollison's work: Mollison, Serodiagnostik; idem., Verwandtschaftsforschung; idem., Anthropologisches Institut der Universität München.

${ }^{620}$ For a biography: Klee, Personenlexikon, p. 154.
} 
Serological Differentiation of the Human Races," also employed the precipitin reaction. He believed that he had established quantitative differences in the abilities of "white serum" and "Negro serum" to react with a certain "white serum-antiserum," which could be demonstrated using precipitation. Fischer qualified his conclusion, however, adding that "before the potential perspective of a serological race diagnosis using such antisera can be considered, $[. .$.$] numerous control and supplementary$ experiments[would be] essential." ${ }^{621}$

At this point Karl Horneck and his mentor Lothar Loeffler entered the stage. Horneck, an Austrian citizen, was born in Graz in 1894. In World War I he fought in the ranks of the Tyrol Kaiserjäger regiment. In 1919 he fought in the "defence of Kärnten," the guerilla war of Austrian snipers against the annexation of part of Kärnten by Slovenia. In the following year Horneck completed his dissertation in medicine. Between 1920 and 1924 he worked in various clinics as "operation disciple," intern and "secondary physician;" from 1924 to 1931 he was a general physician in Feldbach, and from 1927 to 1930 he also directed a small hospital during the construction of the Feldbach-Bad Gleichenberg rail line. At the same time he was also active in the "Protection of the Steyr Homeland" (Steirischer Heimatschutz) and joined the Austrian National Socialists. In 1931 he found a position at the Medical Clinic of the University of Graz, from early 1932, however, only as an unpaid assistant. In 1933 he applied for a position as railway physician, but his application was denied due to his membership in the NSDAP. His application as a panel doctor was not processed for the same reason. In 1934 Horneck applied for a position as chief physician at the Elisabethine Hospital in Klagenfurt, but here, too he was rejected - this time because of his membership in the Protestant Church, as Horneck speculated. ${ }^{622} 1936$ brought the shift in Horneck's career path. Lothar Loeffler brought him to the Race Biology Institute of the University of Königsberg as chief physician, "since he was in a position devoid of prospects in Austria." Horneck had not made any prominent contributions as a scientist at the time - his appointment to Königsberg was due solely to his political loyalty. But then, as Loeffler established in retrospect, he had "worked tremendously hard to become acquainted not only with the scientific questions of the care of genes and race, but also performed practical work from the outset." Although at this point in time he had produced only one scientific paper, ${ }^{623}$ Horneck obtained his professorial qualification before the beginning of World War II, whereby, in Loeffler's words, "the faculty in Königsberg took into account his past and the necessity of practical training." In World War II Horneck was drafted again, held the rank of a staff surgeon, later chief staff surgeon, and earned "the EK [Iron Cross] II in Poland and the EK I at Dunkirk," before he was transferred to the Eastern front. ${ }^{624}$

\footnotetext{
${ }^{621}$ Fischer/Raquet, Beitrag, p. 121 (original emphasis).

${ }^{622}$ Personnel questionnaire on the request for a research stipend, BArch. Koblenz, R 73/11.807.

${ }^{623}$ Horneck received a research stipend from the German Research Association during his time in Königsberg, for "Microscopic Studies about the Structure of the Capillaries Using Infrared Photography." This also concerned changes in the vessels due to "genetic diseases." Cf. Arbeitsplan, BArch. Koblenz, R 73/11.807.

${ }^{624}$ Loeffler to Blome, 17/10/1942, BArch. Koblenz, R 73/12.756.
} 
Horneck continued to work as a scientist while in military service. "In personal, official visits" with Werner Fischer, by this time Director of the Serological Department of the Robert Koch Institute for Infectious Diseases in Berlin, he had arranged to participate, under Fischer's "guidance," in the control experiments Fischer had declared necessary in his essay of $1938 .{ }^{625}$ Possibilities for this of which he never could have dreamed presented themselves in occupied France. Horneck took blood samples from two "Moroccans," one "Annamese" and one "Senegalese Negro" from the ranks of the colonial troops held in war prison camps, and conducted serological investigations on these and other blood samples while on leave, assisted by a French laboratory technician in the Serological-Bacteriological Laboratory of the Hospice Générale du Havre ${ }^{626}$ From the blood samples taken in the war prison camp, Horneck produced "Moroccan, Annamese and Negro sera." These he compared to various "European sera." Over a period of two months, Horneck injected five to seven intravenous injections of these sera in five rabbits, in order to immunize each of them against a specific serum. ${ }^{627}$ Then he killed the animals, let them bleed to death and in this manner obtained a "precipitating antiserum" for each serum injected. A precipitin reaction was induced for each antiserum by combining them with all sera - i.e. with "white, Annamese, Senegalese Negro, and Moroccan serum." Horneck arrived at the conclusion that the "white serum" reacted more weakly in the two cases portrayed in detail - both in the precipitation with "Moroccan serum-antiserum" and with "white serum-antiserum" - and thus possessed less "precipitating antigens" than the other sera. This, Horneck stated, could mean "that the differences present were not actually of race, i.e. based on the circumstance that whites, besides the antigen for the human species, also possess a white antigen, while the Moroccan, Negro, Annamese also possess a Moroccan, Negro, or Annamese antigen in addition to the antigen for the human species; rather, there may merely exist certain differences between whites and the other races in the amount of precipitatable antigens." ${ }^{\prime 28}$ The "determination of the protein content" and the determination of the composition of the protein were thus an imperative prerequisite "for a serological race diagnosis." 229

At Werner Fischer's urging, for this research in 1941 Horneck also began "to attempt the immunization of human to human in different races." ${ }_{30}$ In a later research report Horneck mentions incidentally that these first immunization

\footnotetext{
${ }^{625}$ Horneck, Nachweis, p. 309.

${ }^{626}$ Ibid., p. $318 \mathrm{f}$.

${ }^{627}$ Two rabbits who were treated with "Senegalese Negro serum" perished of peritoneal tuberculoses during this procedure. Since there was not sufficent "Senegal Negro serum" available, Horneck dispensed with immunizing the third animal, so that no antiserum was available for this serum. Ibid., p. 310.

${ }^{628}$ Ibid., pp. 316 f. (original emphasis). It could be that other races possessed more easily precipitatable (lyophobic) serum protein (euglobulins), while Europeans had more strongly lyophilic serum protein (pseudoglobulins, albumins).

${ }^{629}$ Ibid., p. 318.

${ }^{630}$ Ibid., p. 309.
} 
attempts, which had not produced any "usable results," ${ }^{631}$ were performed on himself. However, this account must be cast in doubt - Horneck, who had worked as a general physician for 7 years, after all, must have been aware of the great risks involved with such immunization experiments. It is highly improbable that he bore this risk himself.

"As a consequence of his [...] deployment on the Eastern front,"632 in 1941 Horneck was forced to discontinue his experiments for the time being. He published his results in a paper, which he submitted to the editorial board of the Zeitschrift für menschliche Vererbungs- und Konstitutionslehre on April 20, 1943, and was published in October of that year.

Even before this paper appeared in print, Lothar Loeffler submitted an application for research funding to the German Research Association, in order to allow Horneck to continue his project. The objectives of future investigations were, according to Loeffler, "absolute exclusion of individual differences, especially diseases, within one and the same race," as well as "determination of the protein factions of the antigens." Independent of this, the "experiments about immunization from human to human" were to be continued. Research on "Negroes" was to be continued, "as initially only significantly different races come into question." 633 The medical faculty of the University of Königsberg, he stated further, soon will apply for a military exemption or "working leave" for Horneck, which had good prospects for success. Since the institute in Königsberg was not equipped for such extensive examinations, and the required apparatus could not be procured during the war either, and because the Race Biology Institute being set up in Vienna (Loeffler was just about to move from Königsberg to Vienna at the time) did not yet have a serological workplace, Werner Fischer expressed himself willing to grant Horneck a temporary workplace at the Robert Koch Institute.

Since 1933, Loeffler had first propelled ahead with his research in the field of radiation genetics. Called upon by Alfred Kühn to take part in a joint project for the investigation of genetic damage through X-rays, in December 1933 he had requested a considerable sum from the Emergency Committee of German Science for radiation genetics experiments on mice, which Loeffler wanted to perform in collaboration with Paula Hertwig (1889-1983) of the KWI for Biology and Nikolaj Timofféeff-Ressovsky of the KWI for Brain Research. ${ }^{634}$ The Emergency Committee actually approved a credit of up to 7,000 RM for this project. ${ }^{635}$ Around October 1935 Loeffler had his assistant Karl-Heinz Koch, who had been "initiated in drosophila genetics" by Timofféeff-Ressovsky at the KWI for Brain Research,

\footnotetext{
${ }^{631}$ Karl Horneck, Bericht über die von mir im Januar 1943 begonnenen Untersuchungen über die serologische Verschiedenheit der menschlichen Rassen, n.d. (April 1943), BArch. Koblenz, R 73/12.756.

${ }^{632}$ Grawitz to Himmler, 20/7/1942, quoted in Klee, Auschwitz, p. 166.

${ }^{633}$ Loeffler to DFG, 6/10/1942, BArch. Koblenz, R 73/12.756.

${ }^{634}$ Loeffler to Schmidt-Ott, 9/12/1933, ibid.

${ }^{635}$ Notgemeinschaft to Loeffler, 9/2/1934, ibid.
} 
perform studies on the "question of generating mutations in drosophila through X-rays." "In these studies [work was performed] in very close coordination with Timoféeff-Ressovsky, in order to achieve as great a consistency as possible in work methods and work orientation." ${ }^{3636}$ In June 1936 Loeffler was able to report that the studies, which were part of the joint project sponsored by the German Research Association and the Reich Health Office, already covered 1,100 cultures with over 50,000 animals. ${ }^{637}$ Yet Loeffler had strong competition in this field he had originated, for instance, from the Genetic Biology Department of the Reich Health Office. ${ }^{638}$ Thus, it was altogether logical that he assigned his right hand Horneck to the explosive problems surrounding a serological race test, which - as Loeffler had recognized clearly - touched on not only "important fundamental issues of our science," but also was aimed "at purely practical matters." 639 Thus, Loeffler could open up a new field of research, which was not only of scientific interest, but more importantly - also of immense importance for National Socialist race policy. In this he attached himself to Werner Fischer, who had been working on the complex of themes for some time and had both the required know-how and the necessary infrastructure at his disposal.

For his part, Fischer was happy to accept Loeffler's advances, and bound Horneck's project to his institute, as in this manner he could take advantage of Loeffler's far-reaching political connections in the National Socialist state. This was of particular interest to Fischer because, at around the time Horneck published his first results, he had begun with serological examinations of concentration camp inmates. On this, a report by the Reich Physician SS Ernst Grawitz to Reichsführer SS Heinrich Himmler of July 20, 1942 states:

May I send word that by now Prof. W. Fischer has begun his experiments about serum dif-
ferences in the human races in the Sachsenhausen concentration camp. The first examina-
tions are being performed on 40 Gypsies. Afterward the experiments are to be expanded to
Jews. ${ }^{60}$

Fischer - like Günther Just - was willing to offer a positive opinion about Horneck's research plans. The other personal reference listed besides Fischer was Maximinian

\footnotetext{
${ }^{636}$ Loeffler to DFG, 22/5/1936, ibid.

${ }^{637}$ Loeffler to DFG, 30/6/1936, ibid.

${ }^{638}$ Hans Reiter, President of the Reich Health Office, was noticeably reserved in his position paper for the German Research Association about an application by Loeffler for additional funding. He stated his wish to "emphasize in principle that the radiation genetic experiments on drosophila Professor Loeffler intends to perform also belong to the work area of the Genetic Biology Department of the Reich Health Office. The x-ray apparatus procured for radiation genetic experiments of all kinds, and the manpower available, guarantee a generous execution of radiation genetic work. At this time studies are in progress about the intensification of the genetic radiation effect through pretreatment with chemicals, especially with heavy metal salts, on drosophila." Reiter to DFG, 27/7/1936, ibid.

${ }^{639}$ Loeffler to Blome, 17/10/1942, ibid.

${ }^{640}$ Grawitz to Himmler, 20/7/1942, quoted in Klee, Auschwitz, p. 166. Cf. also idem., Medizin, pp. $163 \mathrm{f}$.
} 
de Crinis (1889-1945), ${ }^{641}$ a National Socialist emigrated from Austria whose curriculum vitae exhibited many a parallel to Horneck's, and who had succeeded Karl Bonhoeffer as full professor for psychiatry and neurology at the Charité hospital in Berlin.

Loeffler bestowed particular urgency upon his application by following it with a letter to Kurt Blome (1884-1969), ${ }^{642}$ Deputy Director of the Main Office for National Health at the NSDAP, a liaison of the German Research Association for the subject area "Population Policy, Care of Genes and Race," who was certain to be one of the people evaluating Horneck's research plan. Loeffler supplied a short synopsis of Horneck's biography, summarizing that he had "proved his worth both politically and in the war." According to report, Loeffler continued, Horneck had been listed in third place for two pending appointments, and it was to be expected that he would move up to positions with more prospects in later appointments, so that, also in view of the "lack of truly good new blood," it was important to give Horneck the opportunity to perform scientific work in the future. Moreover, Horneck was "almost the only race biologist performing serological work at this time." ${ }^{643}$ Blome actually did send Loeffler's letter immediately to the Reich Research Council with a request for review. ${ }^{644}$ One month later - in November 1942 - the Reich Research Council approved the application for a grant of 2,600 RM. ${ }^{645}$

In January 1943 Horneck, who was working in the Special Colonial Medicine Military Hospital in St. Médard near Bordeaux at this time, ${ }^{646}$ resumed his research. In his first preliminary report, Horneck once again described the point of departure of his study: The purpose was to establish whether the varying intensity of precipitin reactions to human sera was influenced by individual factors, especially by diseases, in such a way that the race differences were blurred. Therefore sera of both healthy and sick "Negroes" as well as of whites - for the purpose of comparison were tested using the precipitin method (optimal precipitation), whereby the same blood groups were used in each test. ${ }^{647}$ "With the enormous material" Horneck had "at his disposal an abundance of the most varied diseases, some of which hardly occur at all in our country (like leprosy)." Further diseases he named included

\footnotetext{
${ }^{641}$ For a biography: Jasper, Maximinian de Crinis.

${ }^{642}$ For a biography: Klee, Personenlexikon, p. 54.

${ }^{643}$ Loeffler to Blome, 17/10/1942, BArch. Koblenz, R 73/12.756.

${ }^{644}$ Blome to Breuer, 20/10/1942, ibid.

${ }^{645}$ Reichsforschungsrat to Loeffler, 24/11/1942, ibid.

${ }^{646}$ Horneck to Breuer, 12/1/1943, ibid.

${ }^{647}$ The blood group to which each of the rabbits belonged was also taken into consideration. There were "as we know, rabbits - known as 'A rabbits,' who possess an anti-A factor. Upon pretreatment with A serum, these rabbits give a much more strongly precipitating antiserum, and that is why this fact must be taken into consideration.” Karl Horneck, Bericht über die von mir im Januar 1943 begonnenen Untersuchungen über die serologische Verschiedenheit der menschlichen Rassen, n.d. (April 1943), ibid.
} 
tuberculosis, typhus abdominalis and the worm infection Filaria Bancrofti. Horneck summarized his preliminary results as follows:

To the extent that anything at all can be said about them, these studies showed that individual differences do exist, but that they are expressed only in the time and intensity of flocculation. Thus in such a manner that the serum of a certain subject, e.g., a typhus patient, flocculates earlier and more intensively than the serum of a healthy subject of the same race. However, in all experiments it could be confirmed that with regard to the concentration at which the best (optimal) flocculation occurs, fundamental differences exist between white serum and Negro serum. ${ }^{648}$

In a later, brief interim report Horneck portrayed this preliminary result as already proven and declared categorically: "Differences in the optimal stage of flocculation may thus be based only on race differences." ${ }^{649}$

The studies to "determine the protein factions" had not been tackled yet in the first quarter of 1943. On the other hand, Horneck had resumed his experiments on immunization from human to human:

This time I began the immunization experiments on several Negroes with various blood groups. Before the first injection, about $30-55 \mathrm{ccm}$ blood was taken from each of the Negroes, in order to obtain a serum of the species before treatment. Then the Negroes received a total of $80-100 \mathrm{cmm}$ white serum in four intravenous injections. Twenty-four hours after the final injection and one week after the last [sic, presumably must mean: first] injection, another $50-60 \mathrm{ccm}$ blood was taken from the Negroes. The sera of the pre-treated and those of the non-pre-treated were evaluated for their optimal precipitation and interesting differences were established in this anaylsis. ${ }^{650}$

A portion of these sera was filled into sterile test tubes and sent by courier to Fischer in Berlin, where control tests were to be undertaken. Ernst Rodenwaldt showed animated interest in the immunization experiments in particular. He visited Horneck on location in the Special Colonial Medicine Military Hospital - as mentioned, Werner Fischer had worked as Rodenwaldt's assistant at the Institute for Experimental Cancer Research in Heidelberg from 1933 to 1938. In his later report Horneck noted with disappointment that "extensive attempts at a direct immunization from human to human [proceeded] completely in vain." "The proof of an immunization can only be furnished indirectly via rabbits [...]." ${ }^{651}$ With the immunization experiments on war prisoners of color, Horneck clearly transgressed the boundary to criminal human experiments, for hereby he not only disregarded his proband's right to self-determination - as in taking blood samples for the precipitin reaction, but he also subjected them to serious health risks. For with the injection of the foreign serum Horneck assented to hazard the potential occurrence of allergic

\footnotetext{
${ }^{648}$ Ibid.

${ }^{649}$ Karl Horneck, Bericht über die Arbeit "Serologische Differenzierung der menschlichen Rassen," n.d., ibid.

${ }^{650}$ Ibid.

${ }^{651}$ Karl Horneck, Bericht über die Arbeit "Serologische Differenzierung der menschlichen Rassen," n.d., ibid.
} 
shock, of hemolysis (dissolution of the red blood cells), of intravascular clotting events and thromboembolism with consequent circulatory failure and death.

Apparently Horneck's research came to a standstill when he was transferred from France to Italy in 1943. In November 1943 Loeffler reported to the Reich Research Council that Horneck "has received a command from the Wehrmacht, which now puts him in the position to continue his scientific work despite his continued military service status." ${ }^{652}$ Horneck intended to travel to France in the near future to resume the interrupted research, Loeffler continued. In February 1944 Horneck applied for a further grant of 1,500 RM, which was approved in March. ${ }^{653}$ In October 1944 he informed the Reich Research Council that he had completed a paper "About the Possibility of a Serological Race Differentiation" and sent it to Fischer for appraisal - "with consideration of the fact that this paper contains many new aspects," ${ }^{654}$ Fischer expressed the wish to talk through it with Horneck personally before it went to print, a plan that was frustrated for the time being by the fact that Horneck was denied special leave. The account ends abruptly at this point; the project must have run aground.

Horneck's and Fischer's project is of fundamental importance with respect to Verschuer's project for several reasons:

First, it temporally preceded the "Specific Proteins" project. Verschuer had dealt with the proteins of human serum back in his dissertation in 1923 and showed his lively interest in the possibilities of serological race diagnostics in the late Weimar Republic. In a short paper about "Physiology and Pathology in Anthropology" of 1930, Verschuer had regretted that there was still no success in using the precipitin reaction to "establish with certainty protein differences between the human races." ${ }^{655}$ One must presume that he observed the developments in this field of research attentively. When he succeeded Eugen Fischer in 1942, the race to develop a race test on a serological basis was in full swing - and the institute in Dahlem had not left the starting blocks. Engelhardt Bühler's project begun in 1935, on the heritability of the isoagglutinin content of human blood serum, which - as Eugen Fischer had implied to the German Research Association - also was to open up possibilities for a serological race test, had come to a complete standstill when Bühler was called up to the Wehrmacht at the beginning of World War II. Certainly it can be assumed that Verschuer had taken notice of Fischer's and Horneck's work, and it can also be assumed that he knew about the series of experiments in progress at the Sachsenhausen camp and in the Special Colonial Medicine Military Hospital, perhaps from Lothar Loeffler, who was, after all, a member of the "Dahlem circle," and - as portrayed elsewhere - probably remained in constant contact with the KWI-A because of the fingerprints and handprints from the

\footnotetext{
${ }^{652}$ Loeffler to Breuer, 21/11/1943, ibid.

${ }^{653}$ Horneck to Reichsforschungsrat, 11/2/1944; Reichsforschungsrat to Horneck, BArch. Koblenz, R 73/11.807

${ }^{654}$ Horneck to Breuer, 4/10/1944, ibid.

${ }^{655}$ Verschuer, Physiologie und Pathologie, p. 351.
} 
Wittenau Sanatoriums, ${ }^{656}$ but perhaps through Wolfgang Abel, who, we recall, also had spent time at the Special Colonial Medicine Military Hospital in St. Médard, possibly worked in the Sachsenhausen concentration camp as well, and could have stumbled over Horneck's and Fischer's tracks. Whatever the sources from which Verschuer obtained his knowledge about the competition's project: with the "Specific Proteins" project he attempted to regain the upper hand in this field of research.

Second, the experimental design of the "Specific Proteins" project, as reconstructed by Achim Trunk, corresponded to Fischer's and Horneck's approach down to the last detail - only that Verschuer pursued his goal using Abderhalden's protective ferments rather than the precipitin reaction. Verschuer was familiar with Mollison's attempts to make the precipitin reaction useful for race diagnostics, just as he was with Abderhalden's works, but, as his reviews show, since the late 1930s he granted the better chances to Abderhalden's method. Since he enjoyed a direct connection to Abderhalden, he believed his hand held a decisive trump over Fischer and Horneck.

Third it becomes apparent that the competition between the scientists corresponded to the rivalry between the politicians involved - Conti and Blome. It was all the easier for Verschuer to win over Conti for his plans because the competing undertaking was located in Blome's sphere of influence.

Fourth and finally, against the background of Horneck's project it cannot be excluded that the "Specific Proteins" project utilized the blood of subjects who were $i l l$, perhaps even that of humans who were made ill. Since 1942 Horneck had researched on blood samples of diseased subjects of various races to investigate whether the serum of sick members of a race behaved differently in the precipitin test than did that of healthy members of the same race. This question was also posed in principle by Verschuer in his application of Abderhalden's reaction - in competition with Horneck and Fischer he could not really afford to leave this question unanswered. Thus, it is possible that the 200 blood samples Mengele sent to Dahlem include some originating from diseased inmates. Similarly, against the background of Horneck's research, the suspicion that Mengele purposely could

\footnotetext{
${ }^{656}$ In 1938 Fischer ceded a part of his skull collection to Loeffler, so that he would have demonstration material for the Race Biology Institute at the University of Königsberg. Cf. Fischer to Reichserziehungsministerium, 3/1/1938, MPG Archive, Dept. I, Rep. 1 A, No. 2399, p. 116 a. - Verschuer's stance on Loeffler proceeds from a letter to de Rudder of 10/7/1944: "You know that I actually have him [Loeffler] 'on my conscience' to the extent that I brought him with me from Tübingen to the institute in Dahlem in 1927. But he was an assistant to Dr. Fischer and me for only one year before going to Aichel at the Anthropology Institute in Kiel, where scientific leadership was lacking, and then he drifted off entirely into the political direction, scientifically sterile since 1932, but altogether successful in his career. Now a mammoth institute in Vienna has been approved for him. It remains to be seen whether he will succeed in establishing it. In any case he has set up a fine department for the proficient experimental geneticist Gottschewski, in which work is proceeding intensively. Of late Loeffler has treated me with striking courtesy, while for years he had believed that he could take no notice of me along his path. Even so, he has remained that kind of small mind which likes to make an appearance with arrogance, as a knowit-all claiming that "Goethe is wrong here'." Verschuer to de Rudder, 10/7/1944, MPG Archive, Dept. III, Rep. 86 A (Münster), No. 8.
} 
have infected humans with infectious diseases, such as typhus, cannot be dismissed completely in the context of the "Specific Proteins" project. Moreover, Verschuer was interested in questions of "race pathology," as his paper from 1930 already demonstrated. In this paper he presented "as certain pathological facts" that "numerous genetic disorders like diabetes, deaf-muteness, endogenous psychoses [occurred] in Germany more frequently among Jews than non-Jews and "amaurotic idiocy [had] been observed only in Polish Jews. ${ }^{657}$ As we have seen elsewhere, he was still concerned with "race pathology" in 1939 and 1944 - to that extent it is quite conceivable that Verschuer followed Horneck's experimental design and opened up the "Specific Proteins" project toward a genetic pathology orientation.

\subsection{Relocating and Closing the Institute}

As heavy air attacks on Berlin increased in mid-1943, Verschuer began to look around for possibilities to relocate part of the institute. He managed to rent a house in Sommerfeld, on Lake Beetz, in the direct vicinity of the External Office for Tuberculosis Research in Waldhaus Charlottenburg, which had been expanded and equipped as an auxiliary hospital, but had never been moved into. From July 1943 this Haus am See had been used as a "receiving office for the institute" 658 - it was staffed by Hans Grebe with his secretary, nurse Emmi Nierhaus, Karl Diehl's technical assistant Charlotte Gruetz and the technical assistant Irmgard Eisenlohr, who was involved with the "Specific Proteins" project. ${ }^{659}$ Verschuer had thought about relocating the entire institute to Beetz, but for tactical considerations he dispensed with this idea. If the institute were vacated voluntarily, Verschuer wrote in a letter to Fischer, it might be lost, even if it were not destroyed by air raids. "I could not take responsibility for being at fault myself." In order "to prevent the destruction of our scientific body of thought" he had a wagon load brought to Beetz and Sommerfeld, and in Beetz a hutch for Nachtsheim's rabbits was to be built as well.
With von Wettstein, Butenandt, Heisenberg [Werner Heisenberg (1901-1976), Director of the KWI for Physics] and Eitel [Wilhelm Eitel (1891-1979), Director of the KWI for Silicate Research] (I name only those with whom I actually spoke) we are in agreement that we must defend our institutes here, for they constitute the core of the KWG. If they were to be lost, the entire future of the KWG would but put into question. ${ }^{660}$

Back in September 1943 Gottschaldt, as mentioned above, sent the materials from the "twin camps" from Dahlem to Rottmannshagen Castle near Stavenhagen in Mecklenburg, at the same time further research materials were sent to Haus am See in Beetz. Part of the institute library was brought to Beetz, part to Rottmannshagen.

\footnotetext{
${ }^{657}$ Ibid., p. 351.

${ }^{658}$ Verschuer to Fischer, 30/6/1943, MPG Archive, Dept. III, Rep. 86 A (Münster), No. 9.

${ }^{659}$ Verschuer to Fischer, 20/9/1943, ibid.

${ }^{660}$ Verschuer to Fischer, 25/8/1943, ibid.
} 
In the Dahlem institute, which officially bore the name "Eugen Fischer Institute" since its founding director's 70th birthday in June 1943, ${ }^{661}$ of the valuable goods only the "photograph collection" remained, which was stowed in the air raid shelter. The only staff that continued working in Dahlem were the department heads, Karin Magnussen and a few auxiliary assistants. "This dispersion of items is not ideal," Verschuer wrote, "but provides great reassurance." 662 In order to preserve coherence, he set up a standing "courier service" between Dahlem and Beetz. ${ }^{663}$

In February 1944 the institute was damaged in a heavy bombing attack. Yet Verschuer still regarded the situation to be "by no means so grave that a relocation of the complete institute would come into question." ${ }^{664}$ In the provisionally repaired building ${ }^{665}$ he kept operations afloat for the time being. In September 1944, however, first signs of deterioration became apparent. Lenz, as Verschuer reported, after having brought his wife and children to relatives in Obernfelde near Lübbecke in Westphalia, fell deeper and deeper into depression and could hardly work any longer - shortly thereafter he took leave for reasons of poor health and followed his family to the West, such that the Institute for Race Hygiene ceased to exist in fact. ${ }^{666}$ Abel had "left his people more or less to themselves and consumes aerated baths in Bad Ischl." According to Verschuer, Abel managed "excellently to put his personal affairs in order as advantageously as possible. Now he is shifting ever further away from the institute and has become a rare guest." Karl and Anne Diehl, despite health problems, continued their rabbit research, "albeit often by summoning their last strength;" the same was true of Hans Nachtsheim, who had been declared fit for combat in his army physical, so that it was only a matter of time before he was called up. Gottschaldt was the only one who exhibited "an active demeanor loaded with energy," and pushed ahead "the evaluation of his twin findings with extremely hard work and great energy." However, he was often in Rottmannshagen, where he had lodged his wife and children. The situation there, Verschuer warned, was "by no means harmless, for in the sparsely settled land the foreign workers constitute a majority, which could easily seize power for themselves if enemy pilots were to furnish them with ringleaders." ${ }^{667}$

\footnotetext{
${ }^{661}$ On this celebration in detail: Lösch, Rasse, pp. 417-422.

${ }^{662}$ Verschuer to Fischer, 20/9/1943, MPG Archive, Dept. III, Rep. 86 A (Münster), No. 9.

${ }^{663}$ Verschuer to Fischer, 2/3/1944, ibid.

${ }^{664}$ Verschuer to Fischer, 15/2/1944, ibid.

${ }^{665}$ The broken window panes could not be replaced by September 1943; the empty window frames were sealed with cardboard. Verschuer to Fischer, 20/9/1943, ibid. In January 1945 the coal deliveries stopped, so that only the basement and ground floors could be heated. Verschuer to Lenz, 26/1/1945, MPG Archive, Dept. III, Rep. 86 B, No. 12.

${ }^{666}$ Cf. Verschuer to Lenz, 15/1/1945, ibid. Kröner, Von der Rassenhygiene zur Humangenetik, p. 63, is presumably correct in viewing Lenz's " vacation" " as a "move to withdraw from Berlin." As early as September 20, 1943, though, Verschuer wrote to Fischer: "Lenz is not doing well at all. He suffers greatly from these times and the conditions and has lost even more weight." Verschuer to Fischer, 20/9/1943, MPG Archive, Dept. III, Rep. 86 A (Münster), No. 9.

${ }^{667}$ Verschuer to Fischer, 29/9/1944, ibid.
} 
On February 3, 1945 a directive was issued by the Reich Minister for Armaments and War Production, Albert Speer (1905-1981), to the operations staff of the $\mathrm{KWG}$, instructing that the institutes under its control be relocated from endangered areas. Ernst Telschow forwarded this directive to the KWI-A, where it arrived on February 5, delivered by a courier. Had it been, up to New Year's 1945, Verschuer's express goal to hold out in Dahlem as long as possible and await the further course of events in order to defend the institute building against competing claims, by February 1945 it must have been clear to him that the fall of Berlin was merely a matter of time. Relocating the institute appeared imperative, and in secret Verschuer already had begun the preparations for a move. ${ }^{668}$ So Speer's directive came at just the right time, although initially appearances suggested that it was already too late, for an execution of the directive appeared "impossible." ${ }_{669}$ In addition, between February 5 and 12, 1945 Telschow, as he claimed angrily after the fact, informed Verschuer orally that Speer "in retrospect [had] not desired" the "application of the relocation directive" to the KWI-A. ${ }^{670}$ Although Verschuer later vehemently denied ever having received such a communication, ${ }^{671}$ Telschow's account is confirmed by other sources. ${ }^{672}$ Thus, it can be presumed that Verschuer was quite aware that he had received a green light to relocate his institute neither from the General Administration nor from the Armaments Ministry. However, when Engelhardt Bühler, who had been assigned to the institute a short time before, ${ }^{673}$ managed to organize a trailer truck around February 9, 1945 - to everyone's surprise, ${ }^{674}$ Verschuer acted without delay, supported by Speer's written command to relocate, abruptly overrode the oral counter-command communicated by Telschow and set the relocation in motion. On February 12, 1945, when part of the material sent to Beetz had already been loaded on the truck, he sent a circular to the department heads Abel, Diehl, Gottschaldt, Lenz, and Nachtsheim, officially informing them that the majority of the institute's inventory was to be relocated to his family estate in Solz near Bebra. The Department for Experimental Genetic Pathology remained in Dahlem, since the extensive animal breeds could not be taken with the institute. Nachtsheim was appointed Verschuer's deputy and entrusted with the oversight of

\footnotetext{
${ }^{668}$ Verschuer to Lenz, 9/2/1945, MPG Archive, Dept. III, Rep. 86 B, No. 12.

${ }^{669}$ Verschuer to Lehmann, 23/2/1945, MPG Archive, Dept. III, Rep. 86 A (Münster), No. 5.

${ }^{670}$ Telschow to Verschuer, 12/3/1945, MPG Archive, Dept. I, Rep. 1 A, Ni. 2400, pp. 272-272 v, quotes: p. 272.

${ }^{671}$ Verschuer to Generalverwaltung, 21/3/1945, ibid., pp. 273-273 v.

${ }^{672}$ Kröner, Von der Rassenhygiene zur Humangenetik, pp. 80-83.

${ }^{673}$ After spending time at a military hospital, in January 1945 Bühler was ordered to the KWI-A for 2 months. Verschuer wanted to have Karl Diehl give him a topic from tuberculosis research and station him at the "Haus am See." In 1944 Bühler had submitted a postdoctoral thesis, but this had been rejected by the anatomist Hermann Stieve after Fritz Lenz had refused to head the examination committee. Verschuer endeavored in vain to obtain a professorial qualification for Bühler on the basis of the works he had published so far. Cf. Verschuer to Lenz, 15/1/1945; Lenz to Verschuer, 18/1/1945; Verschuer to Lenz, 26/1/1945, MPG Archive, Dept. III, Rep. 86 B, No. 12.

${ }^{674}$ Verschuer to Lenz, 9/2/1945, ibid.
} 
the institute building and the inventory remaining there. The External Department for Tuberculosis Research stayed in Sommerfeld, as Diehl was indispensable as the senior physician of the Waldhaus Charlottenburg Hospital, and he, too, did not want to leave his animal breeds behind. By contrast, the alternative location Rottmannshagen, under Gottschaldt's direction, was to be dissolved and also relocated to Solz as soon as possible. Some of the "followers" were supposed to remain in Dahlem, some were to move to Solz, and some sent home on leave. ${ }^{675}$

On February 13, 1945 the inventory of the Dahlem institute was loaded on the trailer truck provided. In a letter of February 12, 1945 Verschuer informed the General Administration in writing of the relocation already in progress. ${ }^{676}$ Immediately before his departure, on the afternoon of February 13, 1945, Verschuer must have had another meeting with Telschow, in which the General Secretary vented his anger, but he was not able to stop the operation in progress. ${ }^{677}$ Quite obviously, Verschuer used the chaos predominant in the final phase of the war, above all "the nearly complete collapse of the standard paths of communication," to remove himself from Berlin and in this manner present the General Administration of the KWG with a "fait accompli." ${ }^{678}$ How hasty Verschuer's departure was is apparent in the fact that he did not even find the time to contact Günther Hillmann to discuss the continuation of the "Specific Proteins" project. He left the inventory of the laboratory with the "special rabbit cages for the collection of urine" in Butenandt's institute in Dahlem. "I brought with me only the especially valuable and irreplaceable protein substrates," 679 Verschuer reported from Solz - thus it is possible that some of the sera that ended up in Solz came from the blood samples taken by Mengele in Auschwitz. On the other hand, the written documentation on the "Specific Proteins" project may have been left in Dahlem. On March 12, 1945 Nachtsheim wrote to Verschuer:

From Miss Jarofki [Ruth Jarofki, one of the institute's secretaries] I learned that many files remained here, which should, or must, be destroyed before falling into enemy hands. While I have not yet taken a look to see what and how much is concerned, I presume that Miss Jarofki knows this exactly. You did not speak about this with me, otherwise I would have advised that the things be taken to Solz. In any case we may not choose too late a point in time for their destruction, and I thus consider myself authorized to make the decision on this matter. ${ }^{600}$

\footnotetext{
${ }^{675}$ Kröner, Von der Rassenhygiene zur Humangenetik, pp. $78 \mathrm{f}$.

${ }^{676}$ Verschuer to Generalverwaltung, 12/2/1945, MPG Archive, Dept. I, Rep. 1 A, No. 2400, pp. 265-265 v. On Verschuer's news that a trailer truck had been "made available" to the institute, a marginal comment reads: "without our knowledge and assistance - against the will of R.M. Speer (apparently procured unofficially by Dr. Bühler)."

${ }^{677}$ Verschuer to Geschäftsführender Vorstand der Generalverwaltung, 21/3/1945, ibid., pp. $273-$ 273 v. Here Verschuer also claimed that he had been in contact with Speer by telephone before his departure.

${ }^{678}$ Kröner, Von der Rassenhygiene zur Humangenetik, pp. $83 \mathrm{f}$.

${ }^{679}$ Verschuer to Butenandt, 19/2/1945, MPG Archive, Dept. III, Rep. 86 A (Münster), No. 12.

${ }^{680}$ Nachtsheim to Verschuer, 12/3/1945, quoted in Kröner, Von der Rassenhygiene zur Humangenetik, p. 82.
} 
Verschuer confirmed that some of the material involved was "secret files, which by no means may fall into enemy hands," asked Nachtsheim to attend to the matter and to give the caretaker the order to burn the material "in good time." ${ }^{\prime \prime 1}$

On February 17, 1945 Verschuer laconically informed the General Administration that the relocation of the institute to Solz had been completed "without significant inconvenience." ${ }^{682}$ On March 1, 1945 Gottschaldt arrived in Solz as well, with the material that had been stored in Rottmannshagen. ${ }^{683}$ In a letter to his friend Karl Diehl of March 12, Verschuer appeared optimistic that the institute would be able to continue its scientific work in Solz:

From here I have good news as far as it goes. It is certainly an enormous luxury not to have any sirens in the village and not to feel like a direct target of enemy pilots. As such I manage more positive work than was possible during the last phase in Berlin. The establishment of my small institute here is making progress, although all sorts of difficulties must be overcome. Someday I would like to give you a tour of my facilities here, my Director's study (also living room and bedroom for Erika and me); the library, in which all of the books brought from Beetz have been arranged, which is also the study for Miss Sesselberg (not to mention the group dining room); to the church hall in the manse, which I have furnished as a study for Miss Lüdicke and Nurse Emmi, in which thus the twin files are being analyzed and the institute's administration and treasury are located; and, finally, in a restaurant hall where the institute property is stacked (including that which Gottschaldt has since brought here from Rottmannshagen). ${ }^{684}$

Shortly before Christmas 1944 Eugen Fischer and his wife had fled from Freiburg before the approaching allied troops to their daughter Gertrud in Sontra, near Bebra, so that Fischer and Verschuer found themselves just a few kilometers distance from each other at the end of the war. ${ }^{685}$

In Berlin Nachtsheim had to struggle with increasing signs of dissolution. In fear of the approaching Red Army, many staff members refused to work. Most of Nachtsheim's rabbits had to be slaughtered once the plan to bring the animals to Switzerland had been discarded. Some of the institute's rooms had to be yielded to the Reich Office for Land Use Planning, the Reich Ministry for Church Matters and to a department of the University of Posen. Finally, on March 13, 1945 the institute building was requisitioned as a reserve military hospital. The General Administration of the KWG, angered by Verschuer's going it alone, undertook nothing to prevent the requisitioning. ${ }^{686}$ The General Administration also took a passive stance in the conflict about the Haus am See that broke out in March 1945, when the responsible local group leader requisitioned the building to accommodate refugees. In the end, the KWI-A was left with two rooms of the Haus am See ${ }^{687}$ in which institute

\footnotetext{
${ }^{681}$ Verschuer to Nachtsheim, 24/3/1945, quoted in ibid., pp. $82 \mathrm{f}$.

${ }^{682}$ Verschuer to Generalverwaltung, 17/2/1945, MPG Archive, Dept. I, Rep. 1 A, No. 2400, p. 267.

${ }^{683}$ Kröner, Von der Rassenhygiene zur Humangenetik, p. 84.

${ }^{684}$ Verschuer to Diehl, 12/3/1945, MPG Archive, Dept. III, Rep. 86 A (Münster), No. 7.

${ }^{685} \mathrm{Cf}$. Lösch, Rasse, pp. 426f., $432 \mathrm{f}$.

${ }^{686}$ Kröner, Von der Rassenhygiene zur Humangenetik, pp. $79 \mathrm{f}$.

${ }^{687}$ Diehl to Verschuer, 17/3/1945; Verschuer to Diehl, 29/3/1945, MPG Archive, Dept. III, Rep. 86 A (Münster), No. 7.
} 
property - "numerous scientific apparatus, including special fabrications [...], valuable optics, microtome, projection equipment, part of the scientific library, the twin archive and additional scientific materials" 688 - were stored. Karl Diehl managed to rescue some of these materials in September 1945 when the building was requisitioned for good by the Soviet military authorities. ${ }^{689}$

Along with Nachtsheim, Bühler, Baader, and Magnussen stayed in Berlin. In the end, Verschuer fell out with Magnussen in the course of a conflict within the institute $^{690}$ - she went to Bremen and ultimately returned to teaching after leaving the KWG for good. ${ }^{691}$ Mengele went underground. At the end of the war Abel withdrew to his estate at Mondsee ${ }^{692}$ and dropped out of sight. Heinrich Schade was still a prisoner of war in Yugoslavia. Lenz initially remained in eastern Westphalia, and - as the first of the "Dahlem circle" - was appointed associate professor for human genetic theory at the University of Göttingen in October 1946. ${ }^{693}$ With this it appeared that the institute's "political baggage" had been swept under the carpet. Verschuer indulged himself in the hope that he would be able to reestablish the Kaiser Wilhelm Institute for Anthropology, Human Heredity and Eugenics, whereby of the former department chiefs he wanted to reappoint only his friend Karl Diehl with his tuberculosis research. His relationship to Gottschaldt, who became Director of the Institute for Psychology at the Humboldt University in East

\footnotetext{
${ }^{688}$ Verschuer to an Bürgermeister der Gemeinde Beetz, 9/3/1945, MPG Archive, Dept. I, Rep. 1 A, No. 2400, pp. 270-270 v. Cf. also Verschuer to Generalverwaltung, 9/3/1945, ibid., pp. 269269 v; Telschow to Verschuer, 13/3/1945, ibid., p. 271.

${ }^{689}$ Diehl to Verschuer, 11/9/1945, MPG Archive, Dept. III, Rep. 86 A (Münster), No. 7.

${ }^{690}$ On the background: Magnussen had become friends with Dorothea Michaelsen, Eugen Fischer's secretary of many years (cf. Verschuer to Forstmann, 6/1/1945, MPG Archive, Dept. I, Rep. 1 A, No. 2400, p. 261). In the course of the change in leadership at the institute, Michaelsen had been displaced from her position as executive secretary by nurse Emmi Nierhaus, had taken a long leave of absence for health reasons, and had found herself in fierce conflict with Verschuer in December 1944, who charged her publicly with kleptomania and forced her to resign from the institute (cf. Michaelsen to Generalverwaltung, 21/12/1945, MPG Archive, Dept. I, Rep. 1 A, 3026). Magnussen had sided with her friend (Verschuer to Fischer, 11/10/1951; Fischer to Verschuer, 13/10/1951, MPG Archive, Dept. III, Rep. 86 C, No. 9) with the result that Verschuer fired both women "in the final days in Berlin with the words [...] they all had to leave Berlin; all should take care of themselves" (file note by Telschow of 2/4/1945, MPG Archive, Dept. I, Rep. 1 A, No. 2400, p. 274). In April 1945 Magnussen - together with Michaelsen - moved to her parents' home in Bremen (cf. file note by Telschow of 26/9/1945, MPG Archive, Dept. I, Rep. 1 A, No. 3026). That Verschuer, and later, Fischer as well, broke off contact with Magnussen was clearly because of this "Micha case" (cf., for instance, an undated postcard by Fischer to Verschuer [June 1952], MPG Archive, Dept. III, Rep. 86 C, No. 10), not because of Magnussen's entaglement in Mengele's medical experiments!

${ }^{691}$ Until late 1945 Magnussen was officially listed as an assistant at the institute (cf. Notetat für das KWI-A für das Rechnungsjahr 1945/1946, MPG Archive, Dept. I, Rep. 1 A, No. 3026). Suttinger, "returned from captivity," was supposed to take Magnussen's place from January 1, 1946.

${ }^{692}$ Verschuer to Lehmann, 23/2/1945, MPG Archive, Dept. III, Rep. 86 A (Münster), No. 5.

${ }^{693}$ Extensively on this: Kröner, Von der Rassenhygiene zur Humangenetik, pp. 63-77.
} 
Berlin in 1946, and also with Nachtsheim, who received a chair for genetics at the Humboldt University in 1946, deteriorated visibly.

Verschuer's hope for the reestablishment of the institute was to prove deceptive. His past caught up with him when the physicist Robert Havemann (1910-1982), who had spent the final years of the Third Reich as a political prisoner in the Brandenburg Penitentiary and been appointed by the City Council of East Berlin (Magistrat) as the provisional Director of the Kaiser Wilhem Institutes remaining in Berlin in 1945, exposed Verschuer's connections to National Socialism and his state crimes in 1946. Although at times he was in danger of criminal prosecution and temporarily banned from professional activity, Verschuer ultimately survived the critical situation undamaged ${ }^{694}$ and did well in postwar Germany. However, the Kaiser Wilhelm Institute for Anthropology, Human Heredity and Eugenics, which the General Administration had counted among the core inventory of the Kaiser Wilhem Society immediately after $1945,{ }^{695}$ was implicated so heavily that, although it was never officially dissolved, it was never reopened. ${ }^{696}$ Only Nachtsheim's Department for Experimental Heredity Pathology was recognized by the Max Planck Society, the legal successor to the Kaiser Wilhelm Society, as the Max Planck Institute for Comparative Genetic Biology and Genetic Pathology in 1953 (since 1964: Max Planck Institute for Molecular Genetics) ${ }^{697}$ Hermann Muckermann, who had hibernated in interior emigration for most of the Third Reich, founded a "Kaiser Wilhelm Institute for Applied Anthropology" in Dahlem in 1947/49. Muckermann's application for admission to the Max Planck Society was dragged out by the General Administration. While the "Research Office for Applied Anthropoligy" received financial support from the Max Planck Society, it did not receive the title of a Max Planck Institute. The "Institute for Natural Science and Humanities Anthropology" (Institut für natur- und geisteswissenschaftliche Anthropologie), as it was known from 1952 on, never developed noteworthy activities; it was dissolved without further ado in $1961 .{ }^{698}$ In the end Verschuer was appointed to the newly created chair for human genetics at the University of Münster in 1951, which long remained the only one of its kind.

Even though the Dahlem institute fell apart after the end of the war: the "Dahlem circle" of Verschuer, Lenz, Lehmann, Schade, Weinert, and Schaeuble constituted an "invisible' institution" well into the 1960s, a "network of vertical (teacher/ pupil) and horizontal (colleagues/associates) relationships." Hans-Peter Kröner is correct to warn against a sweeping thesis of continuity, but he draws an equally valid balance, that the "Dahlem circle" exerted "a decisive influence on human genetics and anthropology in the young Federal Republic."'699

\footnotetext{
${ }^{694}$ Ibid., pp. $97-149$.

${ }^{695}$ Ibid., p. 175.

${ }^{696}$ Ibid., p. 1.

${ }^{697}$ Ibid., pp. 209-221.

${ }^{698}$ Ibid., pp. 195-208.

${ }^{699}$ Ibid., p. 2.
} 